\title{
Os contratos comerciais internacionais na sociedade pós-industrial: reflexões sobre a nova lex mercatoria
}

\author{
Dissertação de Mestrado \\ Prof. ${ }^{\text {a }}$ Associada Maristela Basso
}

Alexandre Buono Schulz

n. USP 3370315

Faculdade de Direito da Universidade de São Paulo São Paulo, janeiro de 2010 
Agradeço e dedico este trabalho a meus queridos pais, que tudo me proporcionaram; à minha amada Maíra, cujo amor incondicional me engrandece; e, não menos importante, à Prof. ${ }^{a}$ Maristela Basso, cujos ensinamentos e exemplo são fonte de admiração e inspiração para qualquer pesquisador e profissional do direito 


\section{SUMÁRIO}

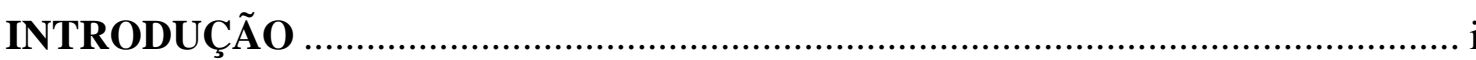

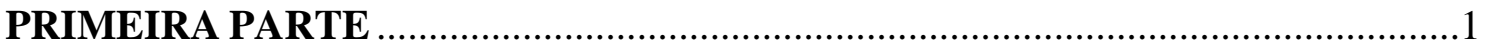

1. A SOCIEDADE PÓS-INDUSTRIAL ....................................................... 1

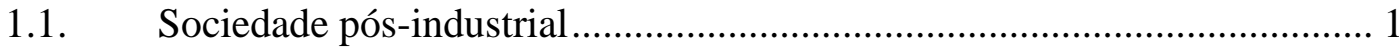

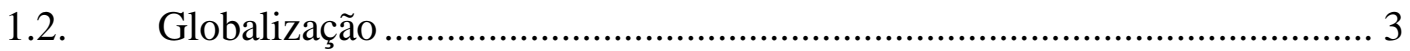

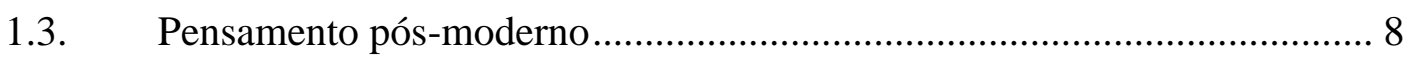

2. O DIREITO NA SOCIEDADE PÓS-INDUSTRIAL ................................... 11

2.1. Transição do moderno ao pós-industrial .................................................. 11

2.1.1. A evolução do contrato: Estado, consensualismo e individualismo.......... 14

2.2. Direito na sociedade pós-industrial: Hermes e a função do direito.......... 19

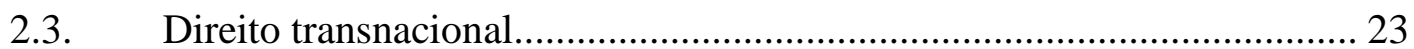

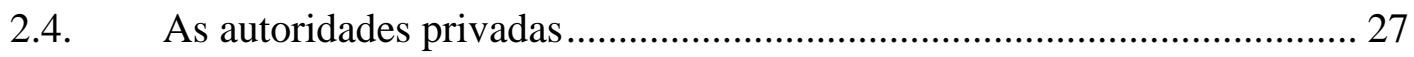

2.4.1. A dicotomia entre direito privado e público .......................................... 30

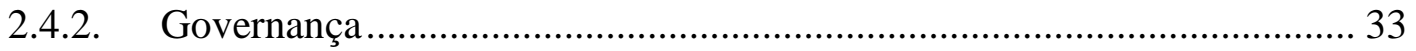

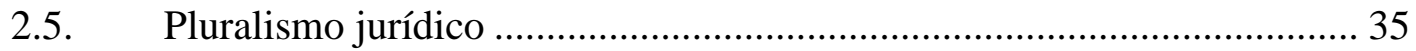

2.6. Informalidade: espontaneidade e oralidade do direito............................ 39

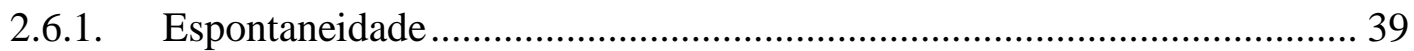

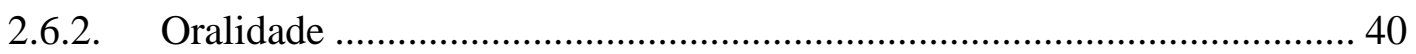

2.7. O contrato na sociedade pós-industrial................................................. 41

2.8. Direito na sociedade pós-industrial: síntese ......................................... 44

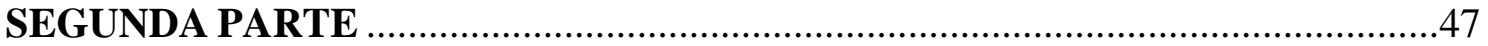

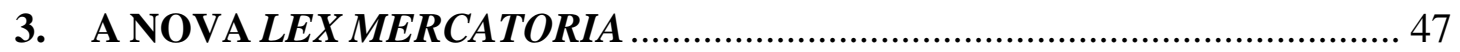

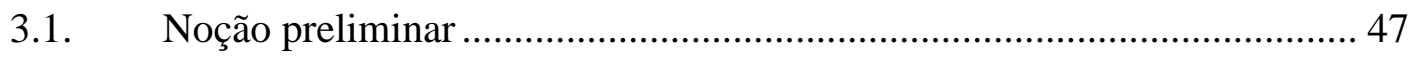

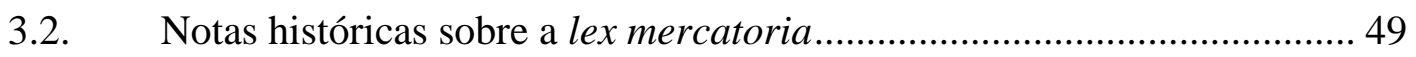

3.2.1. A expressão lex mercatoria …................................................................ 50

3.2.2. A lex mercatoria medieval ................................................................. 51

3.2.3. Nacionalização da lex mercatoria .......................................................... 57

3.2.4. Lex mercatoria contemporânea ............................................................. 61

3.2.5. Diferenças entre lex mercatoria medieval e contemporânea (ou nova lex

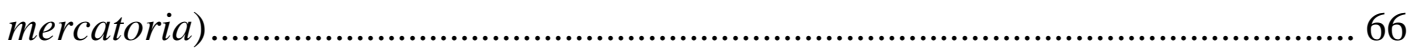

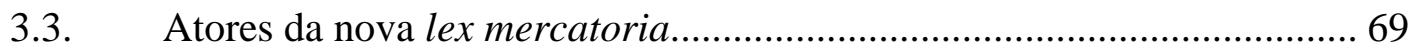

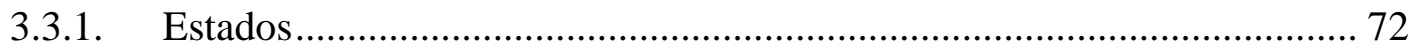


3.3.2. Organizações internacionais e intergovernamentais.............................. 73

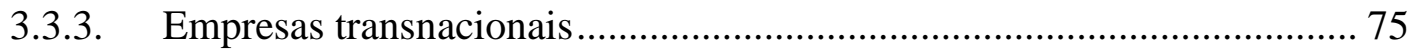

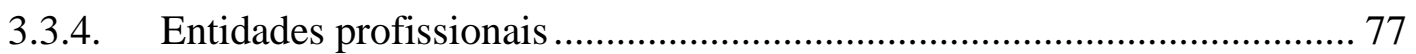

3.3.5. Outras organizações não governamentais................................................ 78

3.3.6. Prestadores de serviços jurídicos .......................................................... 79

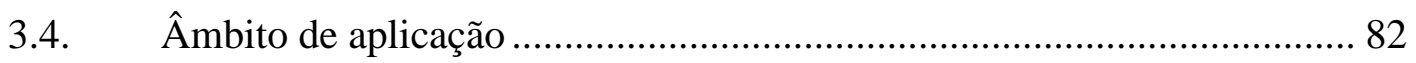

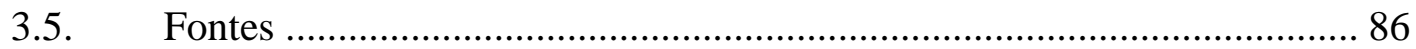

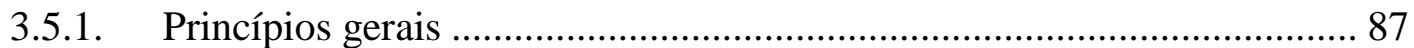

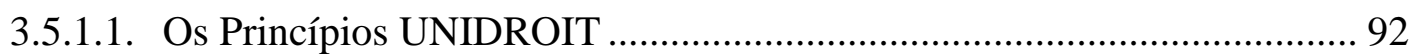

3.5.1.2. A autonomia da vontade como espaço vital da nova lex mercatoria ..... 101

3.5.1.2.1.Os Princípios UNIDROIT e a autonomia da vontade ........................... 104

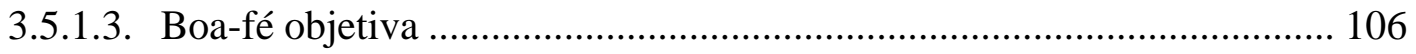

3.5.1.3.1. A boa-fé objetiva nos Princípios UNIDROIT ..................................... 111

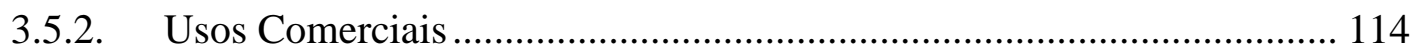

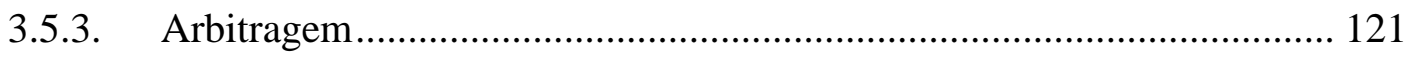

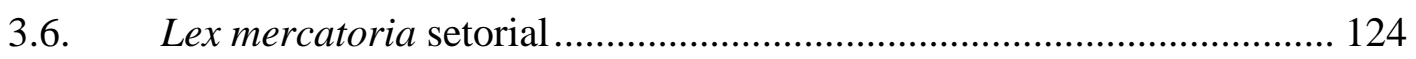

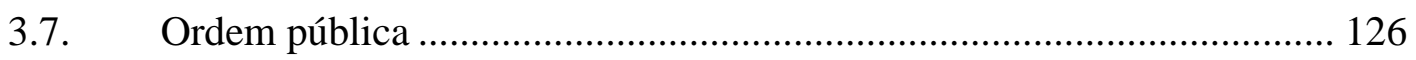

\section{REFLEXÃO CRÍTICA SOBRE A LEX MERCATORIA NA SOCIEDADE PÓS-INDUSTRIAL: DESAFIOS E LIMITES .................................................. 131}

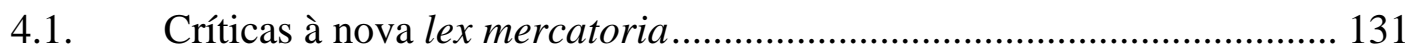

4.1.1. A nova lex mercatoria teria conteúdo vago, incerto e insuficiente e sua aplicação resultado imprevisível ..................................................................... 132

4.1.2. O conteúdo da nova lex mercatoria não seria jurídico ............................ 140

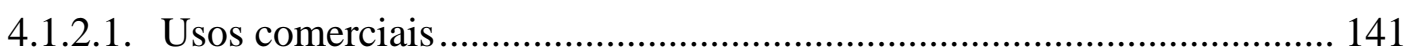

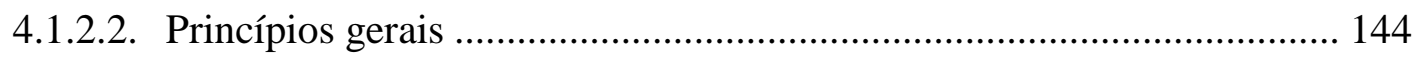

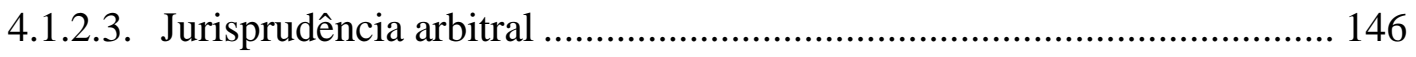

4.1.3. A nova lex mercatoria não constituiria ordenamento jurídico ................ 149

4.1.3.1. A incompletude da nova lex mercatoria ................................................ 150

4.1.3.2. O problema da autoridade, sanções e outros argumentos fundados no

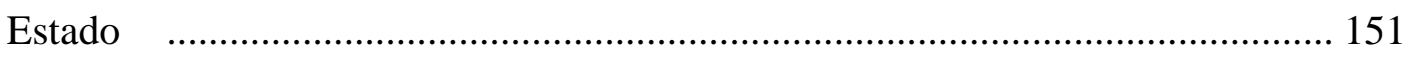

4.1.3.3. A questão da societas mercatorum ........................................................ 156

4.1.3.4. A nova lex mercatoria como ordenamento jurídico ............................... 162

4.1.4. A nova lex mercatoria como fator de desequilíbrio e a questão da

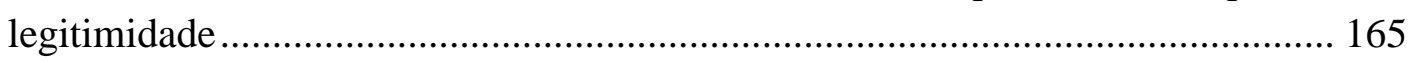


4.2. A nova lex mercatoria na sociedade pós-industrial: noção, limites e

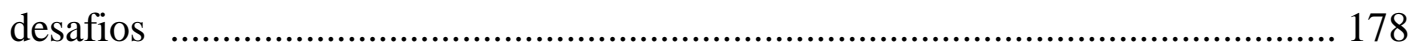

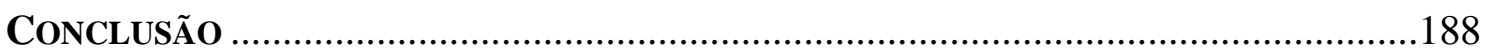

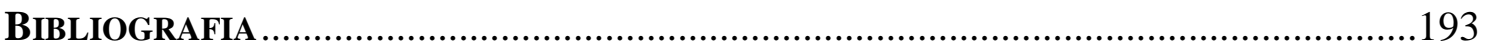




\section{INTRODUÇÃO}

O objeto deste trabalho é analisar o papel dos contratos comerciais ${ }^{1}$ internacionais na sociedade pós-industrial a partir da reflexão sobre a nova lex mercatoria ${ }^{2}$ e respectivos fundamentos, atores, fontes e formação de seu conteúdo, fontes de cognição e momento jurisdicional.

O estudo da nova lex mercatoria foi e continua sendo objeto de inúmeros estudos e controvérsias ao longo dos últimos quase cinqüenta anos, com opiniões apaixonadas tanto de um lado como de outro - os mercatoristas e antimercatoristas, como identifica GAILLARD ${ }^{3}$.

São vários os fatores para tanto. Um deles é o fato de a nova lex mercatoria, tal como sugerida por GOLDMAN ${ }^{4}$ e desenvolvida posteriormente por outros, ter traços jurídicos bastante diferentes daqueles com os quais se está habituado nos últimos dois ou três séculos, a ponto de, não raramente, se aproximar a nova lex mercatoria do ius mercatorum da Idade Média ${ }^{5}$.

Outro fator é a observação de que a nova lex mercatoria se apóia sobre uma societas mercatorum ou business community - o que, advertem alguns de seus críticos, implica a ilusória existência de um grupo homogêneo e organizado de pessoas em escala global, mesmo em um contexto tão fragmentado como o atual ${ }^{6}$.

\footnotetext{
${ }^{1}$ Prefere-se a denominação contrato comercial (e direito comercial) a contrato do comércio (direito do comércio), valendo-se do seguinte apontamento de F. Galgano, Lex Mercatoria, Bologna, Il Mulino, 2001, p. 10: "il diritto commerciale non é il diritto del commercio: non regola ne mai ha regolato, tutto il commercio; non é mai stato un sistema normativo auto-sufficiente, ordinante un intero settore della vita economica".

${ }^{2}$ A perspectiva é eminentemente privada. Está fora do objeto deste trabalho, portanto, a análise do sistema de comércio internacional de que trata o direito internacional econômico (Organização Mundial do Comércio, por exemplo).

${ }^{3}$ E. GAILLARD, Trente ans de lex mercatoria - pour une application selective de la methode des principes generaux du droit, in Journal du Droit International, v. 122, n. 1, 1995, p. 6.

${ }_{4}^{4}$ B. Goldman, Frontières du droit et lex mercatoria, in Archives de Philosophie du Droit, n. 9, 1964, pp. $177-92$.

${ }^{5}$ Como por exemplo, respectivamente, de um lado, F. Galgano, Lex mercatoria... e C. SCHMiTthoff, International Business Law - A New Law Merchant, in Select Essays on International Trade, Chia-Jui Cheng (ed.), Dortrecht, Boston, London, Martinus Nijhoff Publishers e Graham\&Trotman, 1988, pp. 20$37 \mathrm{e}$, de outro lado, M. FoRTUNATI, nella tradizione e nella recente ricostruzione storico-giuridica, in Sociologia del Diritto, v. 32, n. 2-3, 2005, pp. 29-41, e J. BART, La lex mercatoria au moyen age - mythe ou realitè?, in C. LEBEN, E. LOQUIN, M. SALEM (org.), Souveraineté étatique et marchés internationaux à la fin du 20ème siècle, à propos de 30 ans de recherche du CREDIMI - mélanges en l'honneur de Philippe Kahn, Paris, Litec, 2000, pp. 10-22.

${ }^{6} \mathrm{P}$. LAGARDE, Approche critique de la lex mercatoria, in Droit des relations economiques internationales - etudes offertes a Berthold Goldman, Paris, Litec,1982, pp. 125-50.
} 
Por outro lado, a investigação sobre a nova lex mercatoria interessa porque refletiria o modo pelo qual as forças econômicas atuam de forma hegemônica nos dias atuais, com efeitos negativos para outras esferas ${ }^{7}$.

Independentemente do quanto cada uma dessas perspectivas seja verdadeira ou não, de a nova lex mercatoria existir como ordem jurídica própria ou não, alguns questionam a razão pela qual a nova lex mercatoria suscita tantos debates se, na prática, tem pouca relevância. DASSER, por exemplo, relata que entre 1989-1999 foram somente 34 os laudos arbitrais que utilizaram apenas regras anacionais, sendo que: (i) a maioria deles foi escolhida pelos árbitros; (ii) não há como afirmar que todas as regras anacionais sejam parte da nova lex mercatoria; e (iii) alguns árbitros utilizaram essas regras anacionais em conjunto com arbitragem baseada em amiable composition. Além disso, outros 20 laudos combinaram essas regras anacionais com direitos nacionais ${ }^{8}$.

O relatório estatístico de 2008 da CCI verificou que, em 2008, 84\% dos contratos que deram causa a disputas continha escolha expressa de lei nacional. Em apenas 3\% dos casos, as partes escolheram regras anacionais, como a Convenção de Viena sobre a Compra e Venda Internacional de Mercadorias (CISG), de 1980, os Princípios UNIDROIT (e indiretamente a nova lex mercatoria). Apenas em alguns poucos contratos havia referência à nova lex mercatoria por meio da aplicação do direito internacional, direito internacional comercial, princípios gerais universalmente reconhecidos. Em 2007, foram 3 contratos e, em 2006, 2\% dos quase 600 casos, sendo que metade deles com referência à CISG e apenas alguns da outra metade se referiram ao direito internacional comercial, princípios gerais universalmente reconhecidos ${ }^{9}$.

A análise desses dados parecem comprovar, à primeira vista, a tese de Dasser. Mas, então, qual seria a razão para a realização do estudo que ora se propõe?

Esses dados deixam alguns aspectos importantes em segundo plano.

Em primeiro lugar, a nova lex mercatoria não se resume a quando e como é aplicada em arbitragens, já que também é refletida na criação de contratos e outros instrumentos internacionais (como seguros e garantias) ${ }^{10}$.

\footnotetext{
7 Por exemplo, V. OlgIATI, Lex mercatoria e communitas mercatorum nell'esperienza giuridica contemporanea, in Sociologia del Diritto, v. 32, n. 2-3, 2005, p. 351-78.

${ }^{8}$ F. DASSER, Lex Mercatoria - Critical Comments on a Tricky Topic, 2003, cf. disponível [on-line] in http://www.homburger.ch/fileadmin/publications/LMCRIT.pdf [4.1.2009], pp. 2-4.

${ }^{9}$ ICC International Court of Arbitration Bulletin v. 18-20, n. 1, todas as edições.

${ }^{10}$ Vide E. LoQuin, Où en est la lex mercatoria?, in LEBEN; E. LoQuIN; M. SALEM (org.), Souveraineté étatique et marchés internationaux à la fin du 20ème siècle, à propos de 30 ans de recherche du CREDIMI - mélanges en l'honneur de Philippe Kahn, Paris, Litec, 2000, pp. 28 e ss.
} 
Mesmo se assim não fosse e estivesse limitada às disputas, os números não refletem alguns desenvolvimentos recentes. A base de dados da Unilex informa que já são ao menos 215 decisões (arbitrais e judiciais) que fazem referência aos Princípios UNIDROIT, expressão da nova lex mercatoria ${ }^{11}$. Outras 112 decisões (59 das quais laudos arbitrais) utilizam os Princípios UNIDROIT para interpretar ou suplementar o direito nacional aplicável ${ }^{12}$ - dado este que deve ser interpretado com base em duas premissas.

A primeira é o fato de a nova lex mercatoria ter escopo limitado e não regular algumas matérias, motivando sua combinação com os direitos nacionais. A segunda é que a nova lex mercatoria é utilizada muitas vezes como filtro cultural, em conjunto com o direito nacional, o que - como se verá - pode reduzir os custos de informação.

Assim como é certo que nem todos esses laudos devem de fato se referir ou expressar regras da nova lex mercatoria, é também certo que (i) não constituem a totalidade dos laudos arbitrais e (ii) não refletem (especialmente os dados da CCI) se a nova lex mercatoria foi utilizada ou não em conjunto com direito nacional ou em outras circunstâncias - o que de fato ocorre (basta analisar os laudos disponíveis na base de dados da Unilex).

Ademais, a análise da importância da nova lex mercatoria pelo número de decisões que, direta ou indiretamente, a ela façam referência não traz à luz o dado que, comparado à ordem jurídica estatal, a nova lex mercatoria é um fenômeno novo, em desenvolvimento e evolução constante.

Muitos, principalmente do ponto de vista prático, sob o argumento de que seu conteúdo é vago, insuficiente ou de que o resultado de sua aplicação é imprevisível, afastam a nova lex mercatoria e a atribuem importância reduzida ${ }^{13}$.

Uma pesquisa realizada pelo Center for Transnational Law - CENTRAL revelou que a exeqüibilidade do laudo e a falta de experiência prática dos operadores, muitas

\footnotetext{
11 cf. disponível [on-line] in http://www.unilex.info/dynasite.cfm?dssid=2377\&dsmid=13618\&x=I [2811-2009]

12 cf. disponível [on-line] in http://www.unilex.info/dynasite.cfm?dssid=2377\&dsmid=13621\&x=1 [4.1.2009].

13 Vide, por exemplo, F. A. MANN, England rejects 'delocalized' contracts and arbitration, in International and Comparative Law Quarterly, 1984, v. 33, n. 1, p. 193-8 e relatos de Y. DEZALAY; B. GARTH, Merchants of Law as Moral Entrepreneurs - Constructing International Justice from the Competition for Transnational Business Disputes, in Law \& Society Review, v. 29, n. 1, 1995, pp. 27-64, e do resultado da pesquisa realizada pela CENTRAL, disponível [on-line] in http://www.translex.org/output.php?docid=000003 [15.12.2009].
} 
vezes ocasionada pela falta de acesso às fontes da nova lex mercatoria ${ }^{14}$, têm maior peso que as objeções de imprevisibilidade.

Mesmo que seu conteúdo seja - o que será investigado ao longo do trabalho vago, insuficiente e sua aplicação leve a resultados imprevisíveis, essas dificuldades tendem a diminuir ao longo do tempo, com a consolidação da nova lex mercatoria e a difusão e acessibilidade dos laudos arbitrais e das bases de dados on-line, por exemplo.

GAILLARD observa que, enquanto se discutia a respeito da existência da nova lex mercatoria, os operadores do comércio internacional já utilizavam suas regras ${ }^{15}$ - o que é comprovado pelos instrumentos internacionais criados, circulados e colocados à disposição dos operadores e os laudos arbitrais. Para o jurista francês, assentada a concepção de uma nova lex mercatoria - tribunais estatais, por exemplo, já reconheceram a existência da nova lex mercatoria e admitiram sua aplicação $^{16}$-, os estudos devem mudar de foco. Como salienta OSMAN, a discussão então é a da viabilidade da nova lex mercatoria ${ }^{17}$.

Assim, o objetivo deste trabalho é aprofundar as bases de interesse teórico e prático da nova lex mercatoria e, principalmente, descrever os elementos sobre os quais a lex mercatoria se apóia, como ordem jurídica, e sugerir o modo pelo qual a nova lex mercatoria deve se mostrar viável.

A pesquisa se apoiará, tanto quanto possível e reconhecendo a parcialidade de qualquer reconstrução que se faz, em uma abordagem interdisciplinar entre história, antropologia, sociologia e teoria do direito.

A primeira parte do trabalho será dedicada à identificação de fundamentos teóricos da existência da nova lex mercatoria.

O primeiro capítulo identifica, resumidamente, algumas características da transição da sociedade industrial para a sociedade pós-industrial. Em seguida, a atenção é voltada para o fenômeno da globalização, principalmente sob a perspectiva daqueles elementos que afetam a forma como o direito se construía nos últimos dois ou três

\footnotetext{
14 cf. disponível [on-line] in http://www.trans-lex.org/output.php?docid=000003 [15.12.2009].

${ }^{15}$ E. GaIllard, Transnational Law - A Legal System or a Method of Decision Making?, in Arbitration International, v. 17, n. 1, 2001, p. 60.

${ }^{16}$ Vide F. MARRElla, La nuova lex mercatoria tra controversie dogmatiche e mercato delle regoleNote di analisi economica del diritto dei contratti internazionali, in Sociologia del Diritto, v. 32, n. 2-3, 2005, pp. 249-85; L. PANNARALE, Delocalizzazione del diritto e lex mercatoria - linee-guida per una politica dei diritti in una società transnazionale in Sociologia del Diritto, v. 32, n. 2-3, 2005, pp. 315-6 e T. RENSMANN, Anational arbitral awards - legal phenomenon of academic phantom?, in Journal of International Arbitration, v.15, n. 2, 1998, p. 38, n. 23.

${ }^{17}$ F. OSMAN, Les principes généraux de la lex mercatoria - contribution à l'étude d'un ordre juridique anational, Paris, Libr. générale de droit et de jurisprudence, 1992, p. 459.
} 
séculos. Então, recorre-se, também de forma sintética, ao pensamento pós-moderno como ponto de partida inicial para investigar de que modo o direito é alterado na transição da sociedade pós-industrial.

Analisadas as questões conjunturais, e apoiado no contexto moldado pela globalização, o segundo capítulo tem por objetivo identificar alguns contornos do direito da sociedade pós-industrial que o distinguem do direito moderno, ressalvando-se a premissa de que não há ruptura das formas existentes - de maneira que passam a existir novas e velhas fontes do direito.

Para ilustrar essa transição e como base para compreender o papel que o contrato exerce nos dias atuais, são feitos apontamentos sobre sua evolução histórica desde o direito romano até a consolidação do consensualismo e individualismo na modernidade.

O segundo capítulo, então, analisa algumas características do direito nos dias atuais principalmente a partir de uma abordagem sociológica e com contribuições da antropologia. Isto é, os processos sociais tornam-se também transnacionais; a figura das autoridades é uma construção social, cuja conseqüência é a constatação da existência de autoridades privadas e novos contornos do direito privado; e, ainda, o direito também é uma expressão de um grupo social. Assim, adota-se a perspectiva do pluralismo jurídico, ou seja, da existência de várias ordens jurídicas (abaixo, acima, ao lado) além do Estado, o que leva à questão sobre sua relação entre as diversas ordens jurídicas estatais e a ordem internacional - que será mais aprofundada na segunda parte do trabalho.

Em seguida, são analisadas as características informais desse direito da sociedade pós-industrial (espontaneidade e oralidade, que convivem com a formalidade e escritura do direito). Antes de uma síntese dessas características do direito da sociedade pós-industrial que servem de fundamento à nova lex mercatoria, uma vez mais recorre-se ao contrato (como instrumento de inovação jurídica), compreendendo-se suas novas funções nesse contexto e, com elas, as transformações do direito privado.

A partir do suporte teórico desenvolvido no segundo capítulo, a segunda parte deste trabalho se lança sobre a nova lex mercatoria. Primeiro - o que é objeto do terceiro capítulo -, em uma análise mais descritiva do que crítica do fenômeno. A partir de uma noção preliminar e provisória da nova lex mercatoria e de notas sobre a expressão que a designa, traça-se uma breve reconstrução histórica dos antecedentes da nova lex mercatoria, desde a Idade Média até nossos dias, apurando o que diferencia a nova e a antiga lex mercatoria. A compreensão das diferenças entre uma e outra é 
fundamental para sua relação com as demais ordens jurídicas e, portanto, para debater a viabilidade da nova lex mercatoria.

Compreendidos os fatores de nascimento da nova lex mercatoria, trata-se então de identificar quem são os atores da nova lex mercatoria e a quais relações a nova lex mercatoria se aplica. Em seguida, a pesquisa se concentra sobre as fontes da nova lex mercatoria (princípios gerais - com especial destaque para a autonomia da vontade, a boa-fé objetiva e para os Princípios UNIDROIT -, usos e jurisprudência arbitral). Além de identificá-las, a tarefa é analisar o modo pelo qual se forma e se desenvolvem, bem como constatar algumas de suas fontes de cognição, fundamental para sua viabilidade prática. Então, com base na organização das fontes, verifica-se a possibilidade de formação de uma lex mercatoria setorial (ou mais de uma). O capítulo é concluído com a investigação dos limites impostos pela ordem pública à nova lex mercatoria - sem a qual é inconcebível imaginar como a nova lex mercatoria pode se desenvolver.

O último e quarto capítulo parte dos elementos descritos no capítulo anterior para reflexão sobre objeções normalmente formuladas à nova lex mercatoria. Será abordado, assim, o problema do conteúdo da nova lex mercatoria, isto é, não só se é vago, incompleto, incerto e pode levar a resultados imprevisíveis, mas também se é jurídico, ante críticas formuladas principalmente por KASSIS ${ }^{18}$.

O capítulo passa a ponderar, subseqüentemente, as críticas que levam ao entendimento de que a nova lex mercatoria não constitui ordem jurídica - análise para qual a concepção pluralista do direito será essencial - sob o argumento de que o conteúdo não seria jurídico, de que não existiria autoridade e de não seria um sistema dotado de sanções e, por fim, sob o argumento da inexistência da societas mercatorum.

A seguir, a atenção se volta para uma objeção que, do ponto de vista prático, é mais relevante do que as outras: a nova lex mercatoria privilegia interesses econômicos dos que detêm maior poder (principalmente as empresas transnacionais dos Estados do Norte, do Ocidente) em detrimento de outros interesses sociais, políticos ou até econômicos. É com base nessa objeção e nos desafios e limites a que dá causa que o item a seguir, que conclui o trabalho, analisa de que forma deve-se corrigir o curso da nova lex mercatoria para torná-la viável.

\footnotetext{
18 A. KASSIS, L'autonomie de l'arbitrage commercial international - le droit français en question, L'Harmattan, Paris, 2005 e Théorie générale des usages du commerce - droit comparé, contrats et arbitrage internationaux, lex mercatoria, Libr. générale de droit et de jurisprudence, Paris, 1984.
} 


\section{PRIMEIRA PARTE}

\section{A SOCIEDADE PÓS-INDUSTRIAL}

\subsection{Sociedade pós-industrial}

A sociedade industrial caracterizou-se principalmente pela (i) concentração de grandes massas de trabalhadores assalariados nas fábricas; (ii) predomínio de emprego e renda no setor secundário, (iii) descobertas científicas aplicadas na indústria; (iv) racionalização progressiva e aplicação na ciência e na organização do trabalho; (v) divisão social do trabalho e especialização; (vi) separação entre lugar onde se vive e local de trabalho e conseqüente redução da família à família nuclear; (vii) urbanização; maior mobilidade gráfica e social; (viii) aumento da produção de massa e crescimento do consumismo, (ix) fé em um progresso irreversível e em um bem estar crescente, entre outros enumerados por MASI ${ }^{19}$.

A transição para a sociedade pós-industrial ${ }^{20}$ é identificada a partir do momento em que o setor terciário (serviços) passou a ter o maior peso nas economias, superando o primário (agricultura) e o secundário. Daniel Bell, a quem se atribui a denominação de sociedade pós-industrial, fixou seu advento em 1956, quando o setor terciário passou a predominar pela primeira vez nos Estados Unidos ${ }^{21}$. De maneira geral, é possível indicar que seus traços, em maior ou menor escala, já estão presentes desde o fim da Segunda Guerra Mundial ${ }^{22}$.

\footnotetext{
19 D. DE MASI (org.), L'avvento post-industriale, trad. port. de Ana Maria Capovilla, Luiz Sérgio do Nascimento Henrique et al., A sociedade pós-industrial, $3^{\mathrm{a}}$ ed., São Paulo, Senac, 2000, pp. 17-8.

${ }^{20}$ Além do termo 'sociedade pós-industrial', D. DE MASI relata também a utilização por outros autores de "sociedade em impasse", "sociedade despreparada", "idade do equilíbrio", "consciência III", "século casual", "estado de entropia", "sociedade narcisista", "sociedade programada", "sociedade pós-moderna", "cultura pré-figurativa", "sociedade pós-civil”, "sociedade pós-capitalista", "sociedade do capitalismo maduro", "sociedade do capitalismo avançado", "sociedade sadia", "sociedade ativa", "sociedade pósmaterialista", "sociedade tecnotrônica", "terceira onda", "sociedade dos serviços" e "a era da descontinuidade”, cf. D. DE MASI (org.), L'avvento post-industriale..., p. 31. O autor relata também (p. 32), com base em Michael Marien, que o termo sociedade pós-industrial pode ter acepção também de economia agrária descentralizada que se segue a um industrialismo fracassado. Este sentido do termo não é adotado para os fins deste trabalho.

${ }^{21}$ D. DE MASI (org.), L'avvento post-industriale..., p. 35.

${ }^{22}$ D. DE MASI (org.), L'avvento post-industriale..., p. 49. O autor (p. 29) acrescenta que "a passagem de uma fase para outra não significa uma substituição radical da primeira (sociedade industrial) para a segunda (sociedade pós-industrial), significa apenas que um elemento se torna central em lugar de outro, o qual perde a própria hegemonia, mas não sua presença e influência”.
} 
A economia deixa de ser organizada à produção para ser organizada para o consumo. Na era pós-industrial, a produção de idéias e o fornecimento de serviços predominam. O papel do mercado financeiro na economia pós-industrial é de tal forma relevante que alguns fazem referência à economia financeira ${ }^{23}$. FERRARESE identifica um capitalismo de bolsa, afirmando que "a dispetto di tutte le sanzioni morali regolarmente fatte discendere sulla economia finanziaria, il modello di azione sociabile ascrivibile alla logica del 'gioco', con i suoi precipitati di rischio e fortune, se afferma sempre più", sobrepondo-se em relação ao modelo "racional" da economia industrial ${ }^{24}$. Por isso, aponta FERRARESE, à antropologia do consumidor é acrescentada a antropologia do jogador (o homo ludens) ${ }^{25}$.

Esses fatores levam à valorização da informação e do conhecimento como fundamento de produção de riqueza e de inovação tecnológica. É assim que CASTELLS, por exemplo, caracteriza a economia como informacional, na medida em que "a produtividade e a competitividade de unidades ou agentes nessa economia (sejam empresas, regiões ou nações) dependem basicamente de sua capacidade de gerar processar e aplicar de forma eficiente a informação baseada em conhecimentos"26.

Informação e conhecimento são por natureza circuláveis. Assim, as fronteiras e outros limites territoriais tornam-se porosos e a noção de bem ou produto se desmaterializa (e assim o conceito do direito de propriedade), como é evidente no caso dos bens protegidos pelos direitos de propriedade intelectual ${ }^{27}$.

A tecnologia, mais do que instrumento das empresas, passa a ser meio de organização, dando origem a um sistema produtivo em rede, ganhando mais mobilidade e reatividade, tornando-se cada vez mais autoreferencial ${ }^{28}$.

A referência é ao conceito de rede(s), proposto por CASTELLS como "estruturas abertas capazes de expandir de forma ilimitada, integrando novos nós desde que consigam comunicar-se dentro da rede, ou seja, desde que compartilhem os mesmos códigos de comunicação (por exemplo, valores ou objetivos de desempenho). Uma

\footnotetext{
${ }^{23}$ F. Galgano, Lex Mercatoria, Bologna, Il Mulino, 2001, pp. 17 e ss. e M. R. FerRarese, Il diritto al presente - globalizzazione e tempo delle istituzioni, Bologna, Il Mulino, 2002, pp. 29 e ss.

${ }^{24}$ M. R. FERRARESE, Il diritto al presente..., pp. 40 e ss.

${ }^{25}$ M. R. FERRARESE, Il diritto al presente..., p. 30.

${ }^{26}$ M. CASTELLS, The rise of the network society, trad. port. de Roneide Venâncio Majer, A sociedade em rede. A era da informação; economia, sociedade e cultura, v. 1, São Paulo, Paz e Terra, 1999, p. 87. O autor relata que a dependência em relação à informação não é exatamente nova, mas os contornos com os quais tal relação se desenvolve atualmente são inovadores.

${ }^{27}$ F. GALGANO, Lex Mercatoria.., p. 232.

${ }^{28}$ M. R. FERRARESE, Le istituzioni della globalizzazione - diritto e diritti nella società transnazionale, Bologna, Il Mulino, 2000, pp. 38-9.
} 
estrutura social com base em redes é um sistema aberto altamente dinâmico suscetível de inovação sem ameaças ao seu equilíbrio"29.

\subsection{Globalização}

É recorrente a relação da passagem da sociedade industrial à pós-industrial com a globalização ${ }^{30}$.

ARNAUD afirma tratar-se de globalização quando constatada (i) mudança nos modelos de produção, com a mobilidade transnacional das atividades de trabalho e da força de trabalho; (ii) desenvolvimento transnacional dos mercados de capitais, com fluxos financeiros sem levar as fronteiras em conta; (iii) expansão crescente das multinacionais (transnacionais, melhor); (iv) importância crescente de arranjos comerciais entre Estados formando blocos econômicos regionais; (v) ajustamento estrutural que envolve privatização e diminuição do papel do Estado, com hegemonia de conceitos neoliberais em matéria de relações econômicas (mercado privatizado, livre mercado internacional, desregulamentação $)^{31}$; (vi) tendência generalizada à democratização ${ }^{32}$, à proteção aos direitos humanos e um interesse renovado no Estado de direito; e (vii) o aparecimento de novos atores supranacionais e transnacionais ${ }^{33}$.

Em relação ao tema é recorrente a menção à definição de GIDDENS, para quem a globalização seria "the intensification of world-wide social relations which link distant localities in such a way that local happenings are shaped by events occurring many miles away and vice versa" ${ }^{34}$.

BERMAN, no mesmo sentido de Giddens, define mundialização como "intensification of global interconnectedness, in which capital, people, commodities,

\footnotetext{
${ }^{29}$ M. CASTELLS, The rise of the network society..., pp. 498-9.

${ }^{30}$ Globalização e mundialização serão utilizados como termos equivalentes, anotando A. ARNAUD, Entre modernité et mondialisation - Leçons d'histoire de la philodophie du droit et de l'Etat, $2^{\mathrm{a}}$ ed., Paris, LGDJ, 2004, p. 19, que, por uma questão cultural, a língua francesa prefere o termo "mundial" a "global". ${ }^{31}$ Ressalve-se que o texto é resultado de uma conferência proferida por Arnaud em 1997, tendo o movimento liberal sofrido algumas mudanças ou pressões por mudanças e maior intervenção dos Estados (em razão das crises econômicas, por exemplo), de forma que talvez não seja possível destacar as privatizações. A menção feita por Arnaud deve ser considerada menos como uma obra em andamento e mais em relação aos efeitos de uma política neoliberal implementada a partir dos anos 90 do século passado.

${ }^{32}$ A mesma ressalva acima em relação, por exemplo, a alguns países da América Latina.

${ }^{33}$ A. ARNAUD, Entre modernité et mondialisation..., pp. 26-7.

${ }^{34}$ A. GIDDENS (The Consequences of Modernity 1990), citado por W. TWINING, Globalisation and legal theory, New York, Cambridge, 2006, p. 4.
} 
images, and ideologies move across distance and physical boundaries with increasing speed and frequency"

A tradicional definição de globalização de GIDDENS e outras no mesmo sentido se concentram, assim, em uma alteração quantitativa relacionada à economia ${ }^{36}$. FERRARI observa que a economia (e também o direito comercial) sempre teve um caráter global, na medida em que a natureza das relações econômicas é tendencialmente expansiva ${ }^{37}$. TWINING, por exemplo, observa que "it is widely agreed that the processes of globalisation are not entirely new. In some respects, they antedate the rise of the modern nation state...",38.

Analisar a globalização apenas da perspectiva econômica pode levar a resultados indesejados, primeiro porque se corre o risco de fazer prevalecer apenas seu aspecto econômico que, embora relevante, não é suficiente. Segundo Ferrarese, deve-se examinar a globalização sob o prisma de uma alteração qualitativa não só dos processos econômicos, mas também sociais e políticos. Para ela, é na esfera institucional que apresenta traços revolucionários ${ }^{39}$.

ARNAUD assinala que o termo "globalisation renvoie au processus social, économique, culturel e démographique qui s'installe au coeur des nations et les transcende tout à la fois, de telle manière qu'une attention limitée aux processus locaux, aux identités locales, aux unités d'analyse locales rend incomplète la compréhension du local”. Complementa, ainda, que o termo compreende o seu contraposto, o local, em um processo dialético (e, por isso, alguns remetem à glolocalisation $)^{40}$.

\footnotetext{
${ }^{35}$ P. S. BERMAN, From international law to law and globalization, in Columbia Journal of Transnational law, v. 43, n. 2, 2005, pp. 552.

${ }^{36}$ M. R. FERRARESE, Le istituzioni della globalizzazione..., pp. 14-5.

${ }^{37}$ V. FERRARI, Quesiti sociologici sulla lex mercatoria, in Sociologia del Diritto, v. 32, n. 2-3, 2005, p. 7. $\mathrm{O}$ autor sustenta que o mercantilismo, a colonização e os impérios coloniais, as Companhias das Índias, a corrida ao Oriente, por exemplo, também eram "globais". Também M. R. FERRARESE, Le istituzioni della globalizzazione..., p. 12, observa que, na história econômica, a globalização, em termos quantitativos, é intrínseca ao desenvolvimento do capitalismo.

${ }^{38}$ W. Twining, Globalisation and legal theory..., p. 7.

${ }^{39}$ M. R. FERRARESE, Le istituzioni della globalizzazione..., pp. 14-5.

40 A. ARNAUd, Entre modernité et mondialisation..., p. 29. Segundo ARNAUD (p. 28), "on constate, en entrecoup, au niveau local, une réémergence des 'pays', des 'cultures' local, en même temps qu'un retour de la société civile marqué notamment par un accroissement du rôle effective d'association de types divers et des ONG, les unes et les autres jouant un rôle majeur, patent, par exemple, dans la constitution de l'Europe". F. CASUCCI, Il diritto 'plurale' - pluralismo delle fonti e libera circulazione delle norme giuridiche, Napoli, Edizioni Scientifiche Italiane, 2004, pp. 58-9, "la globalizzazione si iscrive in un processo di uniformazione culturale e di azzeramento di conflitti sociali, in prospettiva di un nuovo ordine mondiale, apparentemente pacifico, per un presunto benessere colletivo, ma raprresenta anche un'occasione irrepetibile di dialogo interculturale in favore dell'integrazione fra popolazioni differenti. Infatti, l'economia globale non si limita ad esistere in maniera arbitraria ed assertiva, potendo anche assumere un aspetto benevolo, equo, solidale".
} 
Deve-se distinguir, assim, entre globalismo localizado e localismo globalizado. O primeiro seria a globalização de um fenômeno local; o segundo, a adaptação local em resposta a influências externas. Aos países periféricos não restaria senão a escolha desse globalismo localizado, ao passo que os países centrais se especializam em localismos globalizados ${ }^{41}$.

Uma da perspectivas mais importantes da globalização é analisá-la como redefinição dos limites espaço-temporais. DELMAS-MARTY sublinha, assim como outros, que "la mondialisation actuelle n'est pas la première de l'histoire", não em razão dos processos econômicos em si, mas porque "elle est, pour la première fois, caractérisée par des technologies qui abolissent les distance et se jouent frontières" ${ }^{\prime 2}$.

Criam-se espaços não territorializados, imateriais e, portanto, globais, que não são nem públicos nem privados ${ }^{43}$. $\mathrm{O}$ advento do cyber-espaço, e do on-line ${ }^{44}$ faz com que algumas relações jurídicas intersubjetivas se desenvolvam fora de um espaço físico, "real" "45. TwINING, para quem a globalização na sociedade pós-industrial se distingue não só em razão "the pace and complexity of the processes, especially in the area of communications", mas também pela revisão dos limites territoriais dos Estados e das sociedades, afirma que, tradicionalmente, os estudos antropológicos e sociológicos

\footnotetext{
${ }^{41}$ A. C. CUTLER, Private Power and Global Authority - Transnational Merchant Law in the Global Political Economy, Cambridge, Cambridge, 2003, p. 235 e W. TwinING, Globalisation and legal theory..., p. 5, ambos com base em B. de. S. Santos (Toward a New Common Sense - Law, Science, and Politics in the Paradigmatic Transition, 1995). W. TwINING, Globalization and legal theory..., p. 5, enfatiza: "one needs to distinguish between 'globalized localism' and 'localized globalism': in the former some local phenomenon is successfully globalised - examples include the spread of the English language or American copyrights law; 'localized globalism' occur when local conditions, structures and practices change in response to transnational influences, such as the impact of tourism on local crafts, ecological dumping, or the adaptation of local commercial law to deal with transactions".

${ }^{42}$ M. DELMAS-MARTY, Les forces imaginantes du droit - le relatif e l'universel, Paris, Seuil, 2004, p. 36. Para A. ARNAUD, Entre modernité et mondialisation..., p. 22, "la 'globalisation' conteporaine... se distingue également d'autres types de phénomens qu'on aurait la tentation de rapprocher des précedents, mais dont rendent mieux compte les mots forgés sur le radical 'international"'.

${ }^{43}$ M. Delmas-MARTY, Les forces imaginantes du droit..., pp. 310 e 332. V. Olgiati, Lex mercatoria..., p. 357, caracteriza o fenômeno como uma espécie de curto-circuito espaço-temporal: "nell'ordiena realtà sociale... si vanno estendendo rapporti sia di co-esistenza che di co-varianza tra vecchi e nuovi fenomeni di corporatismo sociale e vecchi e nuovi fenomeni di pluralismo giuridico" ... que "alimentano una crescente cortocircuitazione, spaziale e temporale, tra le più diverse variabili sociali: tra produzione e consumo, tra potere economico e controllo politico, tra bisogni esistenziali primari e rappresentazione sociale degli stessi, e così via".

${ }^{44}$ M. R. FERRARESE, Le istituzioni della globalizzazione..., pp. 42 e ss.

${ }^{45}$ F. Galgano, La globalizzazione nello specchio del diritto, Bologna, Il Mulino, 2005, p. 14. M. R. FERRARESE, Le istituzioni della globalizzazione..., pp. 32-33, aponta que há possibilidade de estender, sem limites, as relações sociais. Entretanto, a linguagem de interesses própria do mercado "collega i soggetti senza legarli". Afirma F. CASUCCI, Il diritto 'plurale'..., p. 63, que "la forza speculativa spinge le dinamiche di sviluppo oltre gli ambiti locali, con conseguenti perditie di valore per un patrimonio sociale fondato sulle differenze, etniche, culturali, religiose e politiche fra le persone".
} 
também estiveram de certa forma cunhados pela noção de fronteiras geográficas, motivo pelo qual novos desafios devem ser encampados por esses saberes ${ }^{46}$.

A sociedade pós-industrial redefine sua relação no que diz respeito aos limites territoriais, alterando também as interações entre os processos econômicos, políticos e sociais, com impactos sobre a soberania do Estado. A soberania do Estado não é, aponta FERRARESE, um jogo de soma zero, e o modo como a soberania foi alterada varia conforme o campo e contexto ${ }^{47}$. Co-existem fenômenos, organizações sociais, instituições abaixo, ao lado e acima do Estado. Se não é razoável afirmar que os Estados não têm mais soberania, também não é razoável afirmar que ela é a mesma. DELMASMARTY, por exemplo, avalia como enfraquecimento dos princípios de soberania e territorialidade do Estado $^{48}$.

DELMAS-MARTY ressalta que ao mesmo tempo em que a mundialização favorece, paradoxalmente reivindicações locais, ele comporta "du développement de stratégies transnationales à caractère privé qui affectent l'ensemble des échanges, qu'il s'agisse des flux économiques et financier, mais aussi scientifique et culturels ainsi que des flux migratoires" ${ }^{49}$. Neste contexto, para FERRARI, a novidade da sociedade pósindustrial é o crescimento da dimensão transnacional, ao lado da internacional. Tornamse transnacionais as redes de comunicação, assim como as empresas, não mais multinacionais, mas transnacionais ${ }^{50}$.

Por outro lado, os fluxos migratórios, de trabalhadores e empresários, por exemplo, são multiplicados e se tornam cada vez mais transnacionais, de forma que diferença cultural não mais possa ser baseada no território ${ }^{51}$. Assim, também ultrapassam fronteiras a cultura, seja material ou simbólica, de massa ou sofisticada, a proteção dos direitos humanos ${ }^{52}$. São criadas comunidades baseadas em afinidades, interesses $^{53}$.

\footnotetext{
${ }^{46}$ W. TWINING, Globalisation and legal theory..., p. 7.

${ }^{47}$ M. R. FERRARESE, Le istituzioni della globalizzazione..., p. 104.

${ }^{48}$ M. DELMAS-MARTY, Les forces imaginantes du droit..., p. 36.

${ }^{49}$ M. DELMAS-MARTY, Les forces imaginantes du droit..., p. 36.

${ }^{50}$ V. FERRARI, Quesiti sociologici sulla lex mercatoria..., p. 9.

${ }^{51}$ P. S. BERMAN, From international law..., pp. 512-5.

${ }^{52}$ V. FERRARI, Quesiti sociologici sulla lex mercatoria..., p. 9.

${ }^{53}$ P. S. BERMAN, From international law..., pp. 512-5. B. GOLDMAN, La lex mercatoria dans les contrats et l'arbitrage internationaux - réalité et perspectives, in Journal du Droit International, 1979, p. 487 afirma que as regras da nova lex mercatoria são anacionais (melhor seria transnacionais, neste caso) porque não são fundadas em sistemas jurídicos nacionais, mas na consciência da sociedade internacional de comerciantes ou societas mercatorum.
} 
Também as relações econômicas são transnacionais. A globalização não unifica os mercados, também em razão das interações locais. Segundo FERRARESE, existe uma pluralidade de mercados, moldados em parte por um processo institucional e em parte por processos informais e espontâneos. Os mercados, como resultado das relações econômicas, também ultrapassam os limites territoriais. Acentua-se, assim, o caráter de estrutura de comunicação dos mercados. Para FERRARESE, assim, "globalizzazione dell' economia non implica dunque unificazione dei regimi giuridici dei mercati, ma piuttosto crescente capacità di tali regimi di comunicare per convergere verso un allargamento degli scambi",54.

Mas, ao mesmo tempo, a globalização dá causa a riscos e disfunções também transnacionais. Assim, salienta DELMAS-MARTY, tornam-se globais, ou melhor transnacionais, os crimes, as exclusões e os riscos tecnológicos (p. ex. biotecnologia), ao meio-ambiente, ao patrimônio comum da humanidade, fazendo com que os diálogos, ações e também a justiça sejam transnacionais ${ }^{55}$.

A análise da globalização não pode ser realizada sob a premissa de um desenvolvimento linear, harmônico, dos fenômenos já destacados. Ressalta OlGIATI que não há "uno sviluppo lineare, ordinato e progressivo, ispirato da un'etica ascetica e da comportamenti metodici, bensì un andamento opportunistico, incoerente e azzardato, dominato da cicliche fasi di crisi economiche e ricorrenti rivolgimenti politici, tali da impedire quindi la certezza delle posizioni, la coerenza dei comportamenti, la durata delle aspettative, ecc". ${ }^{56}$

DELMAS-MARTY destaca que a sociedade pós-industrial se depara com valores fortemente conflituais, como, por exemplo, direitos do homem contra direitos da humanidade, direitos do homem contra o mercado, direitos civis e políticos, contra direitos econômicos, sociais e culturais ${ }^{57}$.

Por essa razão, a globalização requer a construção de diálogos entre as várias ordens de interessados, que não devem se limitar ao elenco tradicional de atores Estados, organizações internacionais e indivíduos -, mas compreender também as organizações não governamentais (ONGs) transnacionais, empresas transnacionais e outros representantes do setor privado e da sociedade civil $^{58}$.

\footnotetext{
${ }^{54}$ M. R. FERRARESE, Le istituzioni della globalizzazione..., pp. 58 e ss.

${ }^{55}$ M. DELMAS-MARTY, Les forces imaginantes du droit..., pp. 37 e ss.

${ }^{56}$ V. OLGIATI, Lex mercatoria e communitas..., p. 357.

${ }^{57}$ M. DELMAS-MARTY, Les forces imaginantes du droit..., pp. 44-5.

${ }^{58}$ W. TWINING, Globalisation and legal theory..., pp. 8-10.
} 


\subsection{Pensamento pós-moderno}

Assim como sociedade e gloablização são associados, não é rara a associação entre esta e o pensamento pós-moderno, como aparato teórico para leitura dos fatos e efeitos da globalização.

ARNAUD afirma que "la globalisation pourrait bien, pour partie, au moins, coïncider intellectuellement avec une pensée juriste post-moderne". Embora ARNAUD identifique conexões, valores e objetivos compartilhados pelo pós-modernismo e pela globalização, o jurista francês destaca que não correto reduzir aquele a esta, principalmente porque, ao passo que - para ARNAUD, baseado no aspecto apenas econômico do fenômeno - a globalização responde apenas à racionalidade econômica, o pós-modernismo se refere a diversas logicas ${ }^{59}$.

"O pós-modernismo representa, em geral”, realça HESPANHA, "uma reacção contra as tendências generalizadoras da 'modernidade', ou seja, da época da cultura européia em que - desde o Iluminismo até ao cientismo triunfante (no domínio das ciências duras e no domínio das ciências sociais) da nossa época - se crê, por um lado, que o nível mais adequado para conhecer e organizar é o geral, o global, e que, por outro lado, esse conhecimento e aditivos, representando vitórias sucessivas sobre a irracionalidade e a desordem"

O Iluminismo, que se desenvolve no século XVIII, embora suas idéias remontem ao século XVII, teve por objetivo a "difusão do uso da razão para dirigir o progresso da vida em todos os seus aspectos... A razão, de fato, é o órgão tipicamente iluminista... para alguns, ela fornece poucas verdades elementares e indubitáveis, que têm o valor dos postulados da ciência e são considerados per si evidentes, a ponto de não exigir demonstração alguma... O Iluminismo, de fato, ... aspira, procedendo com o método racional analítico próprio das ciências, a atingir verdades indiscutíveis ou, quando isto for impossível, generalizações legítimas que tenham uma fundada validade metodológica. A explicação está no fato de que os iluministas têm na razão uma

\footnotetext{
${ }^{59}$ A. ARNAUD, Entre modernité et mondialisation..., p. 272 e pp. 296-9. O autor (p. 267) destaca também que "le fait que les deux problématiques (globalização e pós-modernismo) ne soient pas fréquemment associées teint tout simplement à ce qu'elles sembles concerner des communautés scientifiques différents: la globalisation serait plutôt l'affaire des économistes et des politistes; le post-modernisme concernerait au contraire les philosophes, voire les sociologues".

60 A. M. Hespanha, Cultura Jurídica Européia - Síntese de um Milênio, Florianópolis, Fundação Boiteux, 2005, p. 486.
} 
confiança sem limites e querem libertar o conhecimento humano de tudo aquilo que não seja conforme à razão, especialmente se isto procede da tradição ou da história"61 .

O pós-modernismo é, de acordo com HESPANHA, moldado por um relativismo radical em relação à validade do conhecimento e dos valores que leva à "valorização do multiculturalismo, do pluralismo, da heterogeneidade e da conflitualidade de paradigmas e valores" ${ }^{\prime 62}$. Como decorrência de tal relativismo, aponta o historiador do direito português, a cultura pós-moderna se apóia na idéia de que "os paradigmas culturais e eipistemológicos têm um caráter histórico e aleatório, de que não são "regimes de verdade"”, que é responsável, por sua vez pela “"viragem lingüística' (lingustic turn)... Saberes, sistemas de valores, modelos de comportamento, são encarados como discursos ... "sujeitos a uma crítica que visa desvendar o arbitrário que está na sua origem"

A redefinção dos limites espaço-temporais, a criação de um espaço não geográfico, imaterial, em que parte das relações intersubjetivas se desenvolvem, e a alteração das características da soberania dos Estados, fazem com que se intensifiquem processos sociológicos, econômicos e jurídicos que não gravitem à órbita do Estado, isto é, que não se fundem no Estado.

Os fluxos migratórios do século passado e deste século tornaram obrigatória a convivência de pessoas e grupos distintos, com culturas distintas, forçando com que elas chegassem a um certo entendimento, garantido institucionalmente (Estado de Direito e democracia). Não há mais valores comuns e, também, não há uma realidade única para todos. Nesse contexto, a tolerância desenvolve-se como virtude ${ }^{64}$.

Sob a perspectiva pós-moderna, as particularidades tendem a não ser relevadas ou desconsideradas. Ao contrário, parte-se do reconhecimento e adota-se como premissa um contexto sociológico, axiológico, cultural plural, com profundos reflexos políticos (políticas públicas de defesas das minorias, representação democrática das minorias, por exemplo) e econômicos (ajustes no perfil do consumidor, por exemplo).

$\mathrm{O}$ reconhecimento da multiplicidade de processos sociais e econômicos, em níveis distintos, faz com que a sociedade pós-moderna tenha uma característica

\footnotetext{
${ }^{61}$ N. Bobbio; N. Mateucci; G. PASQuino, Dizionario di Politica, trad. port. de Carmen C. Varriale $e t$ al., Dicionário de Política, $12^{a}$ ed., v. 1 e v. 2, Brasília, Universidade de Brasília, 2004, pp. 605 e ss., especialmente 606.

${ }^{62}$ A. M. HeSPANHA, Cultura Jurídica Européia..., p. 487.

${ }^{63}$ A. M. Hespanha, Cultura Jurídica Européia..., p. 488.

${ }^{64}$ P. L. Berger; T. LuCKMAnN, Modernität, Pluralismus und Sinnkrise-Die Orientierung des modernen Menschen, trad. port. de Edgar Orth, Modernidade, Pluralismo e Crise de Sentido - A Orientação do Homem Moderno, Petrópolis, Vozes, 2004, pp. 38-9.
} 
horizontal, em que a periferia exerce um papel relevante, com impactos para a produção do direito (e sua teoria das fontes). HesPANHA sublinha, dessa forma, que, contra a "generalidade e a abstracção, a racionalidade a planificação e a hetero-disciplina, a funcionalidade" dos modernos, a "reacção pós-modernista (...) ao geral, opõe o particular; ao gigantismo do 'grande' opõe a beleza do 'pequeno' (small is beautiful); à eficácia da perspectiva macro opõe a subtileza da perspectiva micro; ao sistema opõe o 'caso'; à hetero-regulação, a auto-regulação; ao funcional opõe o lúdico; ao objectivo opõe o subjectivo; à 'verdade’ opõe a política (o ‘testemunho', 'o compromisso')"65.

Os processos da globalização e algumas das premissas pós-modernas são úteis, assim, em compreender que determinadas características da sociedade pós-industrial resultam em novas demandas para o direito, cujas respostas não podem mais se fundar somente no direito estatal.

${ }^{65}$ A. M. Hespanha, Cultura Jurídica Européia..., p. 486. 


\section{O DIREITO NA SOCIEDADE PÓS-INDUSTRIAL}

\subsection{Transição do moderno ao pós-industrial}

A transição à sociedade pós-industrial, apoiada naquelas características destacadas sob a rubrica de globalização, conduz ao reconhecimento de características do direito que contrastam com a concepção do fenômeno jurídico na modernidade - e por isso a valia, como ponto de partida, de noções pós-modernas.

Segundo GROSSI, a partir do século XVII, com o advento do Estado moderno e o Iluminismo, o direito passa a ser utilizado também como estratégia do poder político (coincidente com a figura do monarca soberano) para controlar o fenômeno social ${ }^{66}$.

Isto é, busca-se a ruptura com a tradição e com o histórico, com o Antigo Regime. LOPES ressalta que o Príncipe, assim, se liberta das limitações medievais e encampa novo projeto político ${ }^{67}$, com maior envolvimento na produção do direito e combate às fontes jurídicas informais reinantes ao longo da Idade Média ${ }^{68}$.

GROSSI aponta como paradigmático o movimento da codificação, na medida em que, para ele, o "código quer ser um ato de ruptura com o passado: não se trata de uma fonte nova ou de um novo modo de conceber e confeccionar com profundidade e amplitude a velha ordonnance real; trata-se, ao contrário, de um modo novo de conceber a produção do direito e, desse modo, o inteiro problema das fontes, assim como o problema primário da conexão entre ordem jurídica e poder político" ${ }^{\text {69 }}$.

Como resultado de um processo predominantemente político, sujeito e expressão da soberania do Estado, o direito, por um lado, assume um caráter territorializado, e, por outro, se distancia das relações com a sociedade e também com a economia. A lei assume caráter mais formal e de comando, cuja tendência é identificar o direito com obediência $^{70}$ e, conseqüientemente, com sanção ${ }^{71}$.

\footnotetext{
${ }^{66}$ P. GROSSI, Mitologie giuridiche della modernità, trad. port. de Arno Dal Ri Júnior, Mitologias jurídicas da modernidade, Florianópolis, Fundação Boiteaux, 2007, pp. 27 e ss.

${ }^{67}$ J. R. DE LIMA LOPES, As Palavras e a Lei, São Paulo, Ed. 34, 2004, p. 199. LOPES sublinha que, na prémodernidade, o papel do soberano era fazer justiça, fazendo-se direito tanto nos conflitos comutativos quanto distributivos.

${ }^{68}$ P. GROSSI, Mitologie giuridiche...., pp. 35-6, afirma que é deixada de lado uma concepção do direito como realidade "historicamente e logicamente antecedente, que nasce nas vastas espirais do social, com esse se mistura, desse se incorpora".

${ }^{69}$ P. GROSSI, Mitologie giuridiche...., p. 89.

70 J. R. DE LIMA LOPES, As Palavras..., p. 206, que observa que, na pré-modernidade, o direito tem por objeto o bem comum (e.g. condições de convivência universal e felicidade simultânea), sendo que o de cada um (suum cuique) é objeto apenas mediato, indireto. Dessa forma, acompanhando Bártolo de
} 
Este modelo implica, para OsT, além de racionalidade dedutiva e linear e uma crença no progresso pela história, um monismo político, com o desaparecimento das instituições intermediárias ${ }^{72}$, e também o monismo jurídico ${ }^{73}$.

O monismo jurídico reflete a idéia - inadequada, como se verá -, difundida pela consolidação da teoria juspositivista, de que os corpos sociais não produzem direito, de modo que o direito não é outra coisa senão aquele oficial, emanado direta ou indiretamente do Estado $^{74}$.

Sassoferrato, trata-se de realizar a finalidade comum, que dá a medida para as coisas (ex. trocas, vida política), e não de obediência a comandos normativos hierarquicamente superiores. Segundo LOPES (p. 230), legislar consiste, a partir de então, como ato de ordenação e mandamento, em substituição a fazer justiça. Nesse contexto, para P. GROSSI, Mitologie giuridiche...., pp. 39-40, a legitimidade do direito passou a se fundar não mais na adequação das normas a seu fim (justiça, bem comum), mas sim na conformidade de sua produção. $\mathrm{O}$ direito, de processo, passa a ser procedimento. Assim, a tarefa do jurista também assume outras características. De acordo com LOPES (pp. 206-8), a principal tarefa do jurista deixa de ser, como preconizava Bártolo de Sassoferrato, fazer justiça no caso concreto, mas de apreender a vontade do legislador. Nesse contexto, R. DAVID, Les Grands Systèmes du Droit Contemporains, trad. port. de Hermínio A. Carvalho, Os Grandes Sistemas do Direito Contemporâneo, $3^{\mathrm{a}}$ ed., São Paulo, Martins Fontes, 1996, p. 88, enfatiza que "confundir o direito e a lei, ver na lei a fonte exclusiva do direito é contrário a toda tradição romano-germânica esse respeito... Objeto de investigação de todos os homens de boa vontade e muito especialmente dos juristas, o direito não deveria ser exclusivamente procurado nos textos de direito escrito; modificar-se-ia a definição e a própria natureza do direito, se se visse neste não mais a expressão do justo, mas a vontade dos governantes". "E, desse modo," - aponta GROSSI - "nasce a mística da lei, essa pesada hipoteca da civilização jurídica moderna.....".

${ }^{71}$ A. M. Hespanha, O Caleidoscópio do Direito - O Direito e a Justiça nos Dias de Hoje, Coimbra, Almedina, 2007, p. 48, recorda, também, que não só em regimes absolutistas ou totalitários houve a coincidência entre Lei e Estado, frisando que "as revoluções liberais dos finais do século XVIII reforçaram ainda mais este primado da lei”.

72 Com o desaparecimento das instituições intermediárias, uma parcela relevante dos laços de solidariedade e dos sentimentos comunitários é dissolvido. Nessa perspectiva, a sociedade tende a uma simples conjunção de indivíduos, com recuo da sociedade civil. De acordo com P. L. BERGER; T. LuCKMAnN, Modernität, Pluralismus und Sinnkris..., p. 49, o recuo da religião (exemplificativamente o recuo do Cristianismo no Ocidente) agrava o fenômeno, retirando da comunidade a existência de uma ordem de valores supra-ordenada obrigatória. A religião é, de certa forma, substituída pelo Estado. Para A. M. Hespanha, Cultura Jurídica Européia..., pp. 114-5, isso é contrário ao desenvolvimento histórico da sociedade. Na Idade Média, para ele, a idéia era a de "indispensabilidade de todos os órgãos da sociedade e, logo, da impossibilidade de um poder político 'simples', 'puro', não partilhado. Tão monstruoso como um corpo que se reduzisse à cabeça, seria uma sociedade em que todo o poder estivesse concentrado no soberano". Referindo-se, assim, à Idade Média, em que "o poder era, por natureza, repartido; e, numa sociedade bem governada, esta partilha natural deveria traduzir-se na autonomia político-jurídica (iurisdictio) dos corpos sociais. A função da cabeça (caput) não é, pois, a de destruir a autonomia de cada corpo social (patrium corporis operatio própria, o funcionamento próprio de cada uma das partes do corpo), mas por um lado, a de representar externamente a unidade do corpo e, por outro, a de manter harmonia entre todos os seus membros, atribuindo a cada um aquilo que lhe é próprio (ius suum cuique tribuendi); garantindo a cada qual seu estatuto (“foro", "direito", "privilégio"); numa palavra, realizando a justiça (iustitia est constants er perpetua voluntas ius suum cuique tribuendi [a justiça é a vontade constante e perpétua de dar a cada um o que é seu], D., I, 1,1,10,1). E assim é que a realização da justiça - finalidade que os juristas e politólogos tardo-medievais e primo-modernos (séculos XIV - XVI) consideram como o primeiro ou até o único fim do poder político - se acaba por confundir com a manutenção da ordem social e política objetivamente estabelecida".

${ }^{73}$ F. Ost, “Jupiter, Hercules, Hèrmes - Trois Modelés du Juge", in P. Bouretz (org.), La Force du Droit. Paris, Esprit, 1996, pp. 248-9.

${ }^{74}$ C. FARALli, Vicende del pluralismo giuridico - tra teoria del diritto, antropologia e sociologia, in Sociologia del Diritto, v. 26, n. 3, 1999, pp. 99 e ss. 
$\mathrm{O}$ direito, nessa perspectiva juspositivista, que perdurou durante boa parte do século XX, se baseia em um modelo fundado fortemente hierarquizado ${ }^{75}$, em que a legitimação e validade das normas - esclarece OST - se dão em movimentos lineares e unidirecionais, do topo à base da pirâmide, ou seja, o fundamento é a conformidade com os diversos graus ou níveis superiores de normas ${ }^{76}$.

Pouco a pouco, porém, com a transição da sociedade industrial para pósindustrial, criaram-se produtos financeiros, com a concepção da informação e do conhecimento como geradores de riqueza (e a conseqüente desmaterialização do conceito de bem ou produto e do direito de propriedade, portanto), surgiram novas dinâmicas sociais ${ }^{77}$ e formaram-se comunidades de interesse, inventaram-se novas tecnologias que anulam as distâncias, redefinem fronteiras e criam espaços imateriais.

De acordo com GALGANO, trata-se de uma revolução que é adjetivada não só de pós-industrial, mas também digital, espacial, multimídia, global, entre outras ${ }^{78}$. Alterase não apenas "il modo di produrre, ma anche il modo di commerciare e di consumare o, più semplicemente, di comunicare, e sembra spingere le relazioni fra gli uomini fuori del tempo e dello spazio, entro uno spazio non fisico, il cyber-spazio ... in una sorta di spazio vuoto del diritto"79.

Essa redefinição dos limites espaços-temporais levam a um contexto de - como denomina SANTOS - porosidade legal (legal porosity) ou de legalidade porposa (porous legality ${ }^{80}$, exigindo soluções jurídicas que ultrapassem os limites territoriais e possam conceber um espaço jurídico (não necessariamente geográfico).

Além disso, os processos sociais e econômicos da globalização fazem recordar que o Estado não é a única forma de organização social e que o direito não deve,

\footnotetext{
${ }^{75}$ Para KELSEN, por exemplo, o sistema jurídico consistiria em uma pirâmide ou hierarquia de normas, superpostas ou subordinadas umas às outras, superiores e inferiores. Vide H. KELSEN, Reine Rechtslehre, trad. port. de João Baptista Machado, Teoria Pura do Direito, $6^{\circ}$ ed. São Paulo, Martins Fontes, 1999.

${ }^{76}$ F. Ost, “Jupiter, Hercules, Hèrmes..., pp. 246-7.

77 A. M. Hespanha, $O$ Caleidoscópio do Direito..., p. 22, observa que "as sociedades ocidentais se tornavam cada vez mais dinâmicas e diferenciadas. Nas últimas décadas, a imigração acentuou ainda mais o pluralismo destas sociedades, ao trazer para dentro delas, comunidades com sentimentos jurídicos diferenciados, nomeadamente em relação aos padrões usuais na Europa central-ocidental e nas populações brancas dos Estados Unidos". Denota-se, assim, a existência de um multiculturalismo, de um pluralismo axiológico e sociológico, que "o direito oficial tem respondido de forma muito deficiente (entre o desconhecimento e um integracionismo violento)".

${ }^{78}$ F. GALGANO, La globalizzazione ..., p. 13.

${ }^{79}$ F. Galgano, La globalizzazione ..., pp. 14-5.

${ }^{80}$ B. DE S. SANTOS, A Map of Misreading - Toward a Post-Modern Concept of Law, in Journal of Law and Society, v. 14, n. 13, 1987, p. 298.
} 
obrigatoriamente, coincidir com o Estado ${ }^{81}$. Assim, torna-se necessário reavaliar os atores e fontes do direito, na medida em que, destaca FERRARESE, "la globalizzazione significa la coesistenza di vecchi e nuove fonti del diritto, di vecchi e nuovi soggetti giuridici, di vecchi e nuovi istituti, di vecchi e nuovi modo di funzionamento degli stessi

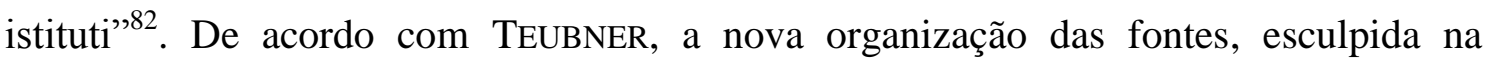
distinção entre centro e periferia, faz com que a juridificação política deixe o vértice da hierarquia e ocupe o mesmo nível de outras fontes ${ }^{83}$. Essa distinção apenas permite que outras possibilidades sociais de normatização sejam reconhecidas como produção jurídica.

Cabe, então, compreender e refletir sobre o mode de realização dessa produção jurídica, o modo pelo qual se insere no contexto atual e se relaciona com as ordens jurídicas estabelecidas (p. ex. estatais).

Esses fatores levam à concepção pluralista do direito, isto é, a um pluralismo jurídico que, enfatiza SANTOS, é o conceito chave de uma visão pós-moderna do direito $^{84}$.

\subsubsection{A evolução do contrato: Estado, consensualismo e individualismo}

A compreensão do desenvolvimento histórico do contrato, como instituto jurídico, e o modo como refletiu os ideiais iluministas e juspositivistas são essenciais para compreender determinados aspectos não só do direito moderno, mas também pressupostos para a realização do direito na sociedade pós-industrial.

\footnotetext{
${ }^{81}$ P. GROSSI, Mitologie giuridiche...., pp. 87 e 104, afirma que o código (e portanto a concepção de leis gerais e abstratas nos moldes juspositivistas) é uma "operação drasticamente redutiva", que "tem por protagonistas sujeitos abstratos aos quais se refere uma faixa de relações igualmente abstratas" e que esses movimentos têm "como denominador comum a tendência de estabilizar o instável" e também de simplificar o complexo e generalizar o que é, no mínimo em parte, particular.

${ }^{82}$ M. R. FerRARESE, Il diritto al presente..., p. 66. G. TEUBNER, Direito, Sistema e Policontexturalidade, Piracicaba, UNESP, 2005, p. 109, ressalta que grande parte das análises, limitadas a aspectos políticos e econômicos, imputa à globalização a crise do direito. $\mathrm{O}$ cerne da questão está na teoria das fontes. Para ele, a "fonte do novo direito global não é mais somente a política institucionalizada...... provém (sobretudo) de outros subsistemas...", tais como "economia, ... ciência, tecnologia, os meios de comunicação de massa, a medicina, a educação, o transporte...". Esses outros setores sociais, segundo TEUBNER, "estão desenvolvendo ... uma enorme necessidade de normas, que não é suprida por instituições estatais ou internacionais", criando os regimes privados globais.

${ }^{83}$ G. TEUBNER, Breaking Frames - La globalizzazione economica e l'emegere della lex mercatoria, in La cultura del diritto nell'epoca della globalizzazione - L'emergere delle costituzioni civili, Roma, Armando, 2005, p. 22.

${ }^{84}$ B. DE S. SANTOS, A Map of Misreading..., p. 297.
} 
$\mathrm{Na}$ sociedade romana, estamental e fundiária, as formas jurídicas, principalmente o contrato, eram vistas como meios de conservação e não de circulação de riqueza.

Não havia, por assim dizer, uma teoria geral dos contratos e, aliás, também não interessava. Em lugar do consensualismo, reinava o rito - a formação dos contratos, na maioria dos casos, tanto no direito romano antigo quanto no clássico, dava-se pela stipulatio, isto é, um contrato formal cuja formação dependia de palavras solenes a serem proferidas pelas partes.

Tampouco imperava o princípio pacta sunt servanda. Cícero, por exemplo, escreveu que "ergo et promissa non facienda..." (assim, há ocasiões em que as promessas não têm que ser guardadas) ${ }^{85}$.

Os contratos eram dotados de elementos naturais e acidentais. É a partir dessa classificação que se delimita a extensão dos pactos no direito romano. Os pactos eram, assim, convenções acessórias a um contrato, voltadas tanto para restringir as pretensões do credor ou a dar-lhes conteúdo. Não geravam obrigações autônomas, mas apenas meios de defesa contra pretensões da outra parte (i.e. não geravam actiones, mas apenas exceptiones), daí que, notadamente, os pacta não pudessem contrariar os essentiala do negócio principal ${ }^{86}$. Se um dos elementos essenciais não estivesse presente, não formava-se um contrato. Tratava-se de um mero pacto (nudum pactum), que não gerava direito de ação. Segundo UlPIANO, "sed cum nulla subest causa, propter conuentionem hic constat non posse constitui obligationem: igitur nuda pactio obligationem non parit, sed parit exceptionem" ${ }^{\prime 87}$.

A fonte das obrigações no direito romano não era a vontade das partes, mas sim o contrato que, em regra, era resultado e dependia de um ato solene das partes.

Assim como os romanos, cujo centro produtivo (pólo sujeito de direitos e obrigações) era o núcleo familiar, os escolásticos não concebiam a individualidade do ser humano. Para Tomás de Aquino, a vida humana consistia numa "busca coletiva de

\footnotetext{
${ }^{85}$ R. HYland, Pacta Sunt Servanda - Una Reflexión, in PETIT, Carlos, org., Del Ius Mercatorum al Derecho Mercantil - 3 Seminario de Historia del Derecho Privado, Sitges 28-30 de Mayo de 1992, Madrid, Marcial Pons, 1997, p. 365. No entanto, lembra J. R. DE LIMA LOPES, O Direito na História Lições Introdutórias, $2^{\mathrm{a}}$ ed., São Paulo, Max Limonad, 2002, p. 392, que, desde a época da Lei das XII Tábuas, alguns contratos eram consensuais, como a emptio venditio, a locatio conductio, o mandato e a sociedade. Já eram familiares e utilizados no mediterrâneo. Consistiam em inovação em contraste com os negócios tradicionais do direito antigo e ritual e passaram a ser protegidos pela ação do pretor. Mas é verdade também que, mais do que regra, os contratos consensuais eram exceção.

${ }^{86}$ J. R. DE LIMA LOPES, O Direito na História..., p. 392.

${ }^{87}$ D. 2.14.7.4: "mas, quando não existe causa, consta que não surge uma obrigação do acordo. Pois um acordo nu não dá origem a uma obrigação, mas sim a uma exceção".
} 
um bem comum, de felicidade.... a ordem social e política e a autoridade não são apenas o remédio para o pecado, são naturalmente elementos que podem conduzir o homem à felicidade" ${ }^{, 88}$.

A noção de liberdade não estava entendida, como para os modernos, dentro de uma esfera puramente individual, mas sim de uma maneira subordinada ao coletivo. Como salienta DEL VECCHIO ${ }^{89}$, o indivíduo é subordinado ao poder público, eclesiástico ou civil.

O direito, por consequiência, é também dotado de uma característica corporativa - presente na lex mercatoria. A lei é "dirigida ao bem comum: tudo tende para um fim, e ação dos homens tende para a felicidade. Cada um busca a felicidade como seu fim e bem. No entanto, essa busca é comum a todos os homens, de modo que há entre todos e cada um uma dialética entre todo e parte" 90 .

GILISSEN observa que "a Idade Média não reconhecia o primado da vontade individual, esta não era respeitável senão nos limites da boa-fé, da moral, do bem comum. Os interesses da comunidade familiar, religiosa ou econômica, ultrapassam os dos indivíduos que a compõem"91. Celebrar um contrato não era matéria de liberalidade ou conveniência.

Para Tomás de Aquino, as partes deveriam ganhar igualmente ${ }^{92}$. É nessa conjuntura, então, que se fortalecem os conceitos de justiça distributiva e comutativa ${ }^{93}$, bem como a teoria do preço justo ${ }^{94}$ e por conseqüência a proibição à usura.

\footnotetext{
${ }^{88}$ J. R. DE LIMA LOPES, O Direito na História..., pp. 146-7.

${ }^{89}$ G. DEL VECCHIO, Historia de la filosofía del derecho, $2^{\mathrm{a}}$ ed., Barcelona, Bosch, 1964, p. 34.

${ }^{90}$ J. R. DE LIMA LOPES, O Direito na História..., p. 152.

91 J. GILISSEN, Introduction historique au droit, trad. port. de António Manuel Botelho Hespanha e Manuel Luís Macaísta Malheiros, Introdução Histórica ao Direito, $4^{\mathrm{a}}$ ed., Lisboa, Calouste Gulbenkian, 2003, p. 737

${ }^{92}$ P. S. ATIYAH, The rise and fall of freedom of contract, New York, Oxford, 1985, p. 61.

93 A escolástica é um retorno parcial à filosofia clássica. Em Aristóteles, a justiça distributiva era distribuição proporcional, em proporção geométrica. A justiça retificadora (ou igualadora ou sinalagmática), por sua vez, se dá em proporção aritmética. Ninguém recebe nem mais, nem menos. Esta forma de justiça, quando determina a formação de relação de troca segundo uma medida, consiste na justiça comutativa. Quando necessita de intervenção, tem-se a justiça judicial. E a eqüidade é o instrumento corretivo da justiça. Vide G. DEL VECCHIO, Historia de la filosofía ..., p. 34. Para Tomás de Aquino, a justiça particular divide-se entre justiça comutativa e justiça distributiva e, cf. J.R. DE LIMA LOPES, O Direito na História..., p. 393, “em ambas o que está em jogo é o bem particular de pessoas particulares, mas dentro de uma comunidade". A primeira diz respeito à relação das partes umas com as outras, uma troca entre iguais, a dar a cada um o que é seu, ao passo que a distributiva tem relação entre as partes e o todo, a comunidade, a dar a cada um o que é comum. A justiça comutativa "inseria-se num todo orgânico e harmônico de justiça política e política distributiva", configurando-se assim um "mecanismo de equilíbrio social, de paz e de justiça".

${ }^{94}$ Como realização dessa justiça, a idéia de preço justo tomou forma e força. Como lembra P. S. ATIYAH, The rise and fall..., p. 62, o preço justo foi centro do pensamento econômico medieval e, na Inglaterra,
} 
Em uma sociedade com baixa mobilidade social, cujo parâmetro de riqueza é ainda a terra (é a época, também, dos feudos como centros de poder), os contratos, além do requisito da causa, deveriam ser quantificados de forma objetiva, como costumeiramente praticado na comunidade.

No direito medieval, direito e moral ficaram ainda mais próximos. $\mathrm{O}$ elemento ético era imanente à teoria contratual, enxergando nesse instrumento jurídico o fim último de justiça, não só entre as partes, mas também (e principalmente) com a coletividade.

O direito canônico - ainda que direito e moral mantivessem relação estreita ("os contratos obrigam por concretizarem a lei de Deus" ${ }^{\text {"95 }}$ ) - exerceu papel fundamental para as bases da teoria contratual moderna, fundada na autonomia da vontade, noção estreitamente relacionada ao individualismo.

Desde cedo, a Igreja mostrou-se favorável ao respeito da palavra dada. Já nos séculos IV e VI, há textos associando a mentira ao perjúrio. Graciano, no séc. XII, escreve que a promessa deve ser mantida sob pena de pecado. Teotonicus, na sua glosa ao Decreto de Graciano, foi o primeiro a enunciar que ex nudo pacto, actio oritur (uma ação pode originar-se de um pacto nu) ${ }^{96}$.

Já nas Decretais de Gregório IX (1234) consta que "pacta quantunque nuda sevantur". Segundo um documento canônico, "la acción basada en el mero acuerdo nace de la equidad natural, que debe ser preferida por el juiz siempre que difiera del Derecho positivo. La equidad exige que los actos de una persona se correspondan con sus palabras"97.

Ainda sob a perspectiva do elemento ético, é interessante notar como a boa-fé, entendida como ausência de pecado, exerce papel de legitimação dos nuda pacta ${ }^{98}$. $\mathrm{O}$

por exemplo, exerceu influência até 1770. Isto não quer dizer, porém, que os preços não poderiam variar. O preço estava sujeito ao mercado, como, por exemplo, influências de uma safra ruim.

95 A. M. CORDeiro, Da Boa-Fé no Direito Civil, Coimbra, Almedina, 2001, p. 154.

96 J. GILISSEN, Introduction historique au droit...., p. 735.

${ }^{97}$ R. HYLAND, Pacta Sunt Servanda..., p. 367.

98 A. M. CORDEIRO, Da Boa-Fé..., pp. 153-4 observa que "no Direito romano, a boa-fé apareceria com um conceito e um alcance substancialmente diferentes, consoante aplicada às obrigações ou à posse: nas primeiras, opondo-se a fraus e dolus, traduz as idéias de honestidade, fidelidade e consciosidade; na segunda, contracenando com a má-fé, expressaria, apenas uma ignorância justificada. No Direito canônico, pelo contrário, teria ocorrido uma velha aspiração dos estudiosos da boa-fé: a sua unificação conceptual. Na linha dos valores próprios do Direito da Igreja, a boa-fé dependeria sempre da consideração do pecado: na praescriptio, a mala fides superveniens, traduzindo uma situação de scientia na constância do direito alheio, corporizaria um factor de conscientia, obstáculo ao seu funcionamento; por isso foi alterado o brocardo romano mala fides superveniens non nocet. Nos nuda pacta, a idéia de pecado teria sido, também, decisiva: o respeito à palavra dada impõe-se, sob pena de violação dos valores transcendentais". Assim, no direito canônico, a boa-fé ganhou uma dimensão ética. 
direito canônico passou a reconhecer a vinculação das partes pelos pacta nuda, defendendo a consensualidade dos contratos e o respeito à palavra. Entretanto, o direito canônico não elevou o pacta sunt servanda a princípio fundamental ou mesmo o formulou como máxima ${ }^{99}$.

Os filósofos Duns Scotus (1266-1308) e Guilherme de Ockham (1290-1349), da escola nominalista, exerceram papel fundamental na construção teórica da autonomia da vontade - e, portanto, do consensualismo e individualismo, afirmando que a vontade comanda o intelecto e é a causa do ato. Conseqüientemente, a fonte das obrigações não são mais os contratos, celebrados segundo ritos e formalidades predeterminados, mas sim a própria vontade. São expressão da vontade humana.

Mas a autonomia da vontade triunfa apenas alguns séculos depois, com o jusracionalismo, a partir de, por exemplo, Hobbes, Locke, Rousseau, Grócio, Francisco de Vitória, entre outros, e principalmente Pufendorf (a quem se atribui a máxima pacta sunt servanda). É a partir deles que, em conjunto com o posterior pensamento utilitarista, a autonomia da vontade, traduzida no consensualismo, fundamenta a teoria moderna dos contratos ${ }^{100}$.

A partir do século XVI, fortaleceram-se assim o consensualismo, a autonomia da vontade (forma de livre transferência de liberdades) ${ }^{101}$ e o individualismo, que “suplanta(m) a concepção comunitária do direito (...) daqui em diante, é o homem, enquanto indivíduo isolado, livre com a capacidade de dispor de sua pessoa e seus bens, que constitui o sujeito de direito"102. O preceito jusnaturalista consiste fundamentalmente em abster-se do alheio, traduzindo-se nas seguintes regras do direito natural: “(i) devolver o que se obteve ilicitamente; (ii) cumprir as promessas; (iii) reparar os danos; (iv) punir os culpados"103.

Nos séculos XVI e XVII, então, “a velha sociedade de ordens (dos guerreiros, religiosos e trabalhadores - bellatores, oratores e lavoratores) cede lugar a uma vida

\footnotetext{
${ }^{99}$ R. HYLAND, Pacta Sunt Servanda...., p. 364.

${ }^{100}$ F. WIEACKER, Privatsrechtgeschichte der Neuzeit unter Besonderer Berücksichtigung der Deutschen Entwicklung, trad. port. de António Manuel Botelho Hespanha, História do Direito Privado Moderno, $2^{\mathrm{a}}$ ed., Lisboa, Calouste Gulbenkian, 1967, pp. 350-1.

${ }^{101}$ J. R. DE LIMA LOPES, O Direito na História..., p. 400, observa que "a autonomia da vontade, imaginada como liberação do homem, quando domesticada numa teoria de trocas cujo centro de gravidade é o capital, foi apenas um seu aspecto: paradoxalmente foi ela que permitiu a alienação, a sujeição de uns perante os outros, como intuiu com precisão Marx". O autor, em As Palavras..., p. 226, lembra que os contratos, como livre transferência de liberdade, encontra seu fundamento na promessa e na virtude de fidelidade, destacando-se então a justiça comutativa.

${ }^{102}$ J. GILISSEN, Introdução Histórica..., p. 737.

${ }^{103}$ J. R. DE LiMA LOPES, As Palavras..., p. 226.
} 
crescentemente aburguesada, em que os deveres feudais e pessoais se transformam em obrigações pecuniárias. Neste mundo, de relações econômicas abstraídas das relações pessoais, a promessa e o exercício individual da vontade ganham uma dimensão nova. Da teoria dos contratos como realização de negócios essencialmente justos, passa-se a uma teoria dos contratos como obrigação derivada da vontade e da promessa"104.

Até o século XVII (ou seja, transição para a modernidade), aponta LOPES, os juristas se ocupavam da justiça distributiva (fundada na noção do indivisível, do comum), cuja distinção com a justiça comutativa (particular, em que as pessoas são singularmente consideradas, mas então como parte do todo) era ponto de partida fundamental no arcabouço filosófico do curso de introdução ao estudo do direito. Na modernidade, complementa, houve uma cisão: a troca (cuja justiça, com raízes no jusnaturalismo e no intersubjetivismo, permaneceu como objeto do Direito) substituiu a cooperação.

A modernidade, nessa perspectiva, deve ser analisada também como libertação do indivíduo, em termos antropológicos.

Como observado, o individualismo, consolidado pelo triunfo do Estado moderno, o favoreceu, tendo reflexos também na ciência política. A "dialética-exclusiva 'Estado-indivíduo"” ${ }^{105}$, com a formalização do direito, resultou no enfraquecimento do comum, do senso de comunidade, dos laços de solidariedade - com deformação dos sentimentos jurídicos espontâneos ${ }^{106}$.

\subsection{Direito na sociedade pós-industrial: Hermes e a função do direito}

As principais características do direito pós-moderno - a que muitos denominam de direito global ${ }^{107}$ e que, provisoriamente podem servir como guia para a reflexão do

\footnotetext{
${ }^{104}$ J. R. DE LIMA LOPES, O Direito na História..., p. 217. O autor (p. 220) observa ainda que “os modernos ... constroem o seu sistema racional a partir de postulados prévios e dentro deles organizam as suas máximas tradicionais. É assim que o pacta sunt servanda adquire um sentido novo: de uma máxima menor na teoria dos pactos (isto é, acordos paralelos aos contratos), transforma-se numa regra geral da teoria das obrigações".

${ }^{105}$ P. GROSSI, Mitologie giuridiche...., p. 64-5.

${ }^{106}$ A. M. HeSPANHA, Cultura Jurídica Européia..., pp. 116 e ss.

${ }^{107}$ A referência ao direito dos dias atuais como direito global ou direito da globalização é contestada por outros autores (vide F. CASUCCI, Il diritto 'plurale'..., p. 29 e V. OlgIATI, Lex mercatoria $e$ communitas..., p. 368), que apontam ser uma expressão axiomática e que não há um fenômeno únificado que assim se possa denominar. A adoção da expressão "direito na sociedade pós-industrial" quer significar um gênero de fenômenos jurídicos, expressões do direito, cujas características se distanciam do direito moderno e são influenciadas ou moldadas pela globalização e, em parte, pela concepção pósmoderna do direito.
} 
direito na sociedade pós-industrial - são dadas principalmente em comparação ao direito dos últimos dois ou três séculos.

Segundo ARNAUD, o direito pós-moderno assume em vez da abstração moderna, o pragmatismo pós-moderno; a descentralização do sujeito no lugar do individualismo (desconstrução da idéia do direito fundado na superioridade do indivíduo); contra o universalismo, o relativismo; emerge uma pluralidade de racionalidades e um contexto fragmentado, em substituição à hierarquia e à concepção piramidal da ordem jurídica; a complexidade contrapõe a simplicidade; o fortalecimento da sociedade civil, em detrimento da relação indivíduo-Estado; e, ainda, no lugar da segurança, risco ${ }^{108}$.

O pragmatismo significa, para ARNAUD, uma regulação social que se apóia menos em conceitos do que no pragmatismo, isto é, em práticas culturais e em apoio a políticas conjunturais, desenvolvendo um "direito negociado" 109 .

FERRARESE ressalta que o direito tende, dessa forma, a ser um produto sempre negociável, seja em relação à sua forma, execução, conteúdo e produção. Por isso, por um lado, o contrato passa a ter um papel central - comenta-se até da contratualização do direito - e, por outro, outros atores que não o Estado e os magistrados - os profissionais do direito, especialmente as law firms de estilo americano - ganham relevância ${ }^{110}$.

De acordo com ARNAUD, o pragmatismo leva, segundo o jurista francês, ao reconhecimento de um certo relativismo (cultural e temporal ${ }^{111}$ ), entendido em contraposição ao universalismo ${ }^{112}$. Este consiste na “...idée ethnocentriste selon laquelle les produits de la philosophie occidentale sont valables urbi et orbi...fondée notamment sur le subjectivisme qui a permis, entre autres développements, l'emergence des Déclarations des droits de l'homme e du citoyen"113. Como salienta WALLERSTEIN, "o universalimso europeu, conjunto de doutrinas e pontos de vista éticos que derivam do contexto europeu e ambicionam ser valores universais globais - aquilo que muitos de seus defensores chamam de lei natural" ${ }^{, 114}$.

Observa FERRARESE que a globalização coloca as pessoas cada vez mais em contato, cria novos meios de intersubjetividade, dando origem a uma poligamia de

\footnotetext{
${ }^{108}$ A. ARNAUD, Entre modernité et mondialisation..., p. 272.

109 A. ARNAUD, Entre modernité et mondialisation..., pp. 278-9.

${ }^{110}$ M. R. FERRARESE, Le istituzioni della globalizzazione..., p. 35 e ss.

${ }^{111}$ A. ARNAUD, Entre modernité et mondialisation..., p. 280: "les lois n'ont plus, contrairement à ces que pensaient les rédacteurs du Code Napoléon, vocation à la perpetuitè".

${ }_{112}$ A. ARNAUD, Entre modernité et mondialisation..., pp. 279-80.

113 A. ARNAUD, Entre modernité et mondialisation..., pp. 274-5.

114 I. WALlERSTEIN, European Universalism - The Retoric of Power, trad. port. Beatriz Medina, $O$ Universalismo Europeu - A Retórica do Poder, São Paulo, Boitempo, 2007, p. 60.
} 
lugares. Este multilocalismo, em que os lugares são escolhidos pelos indivíduos (ou empresas) por conveniência (com consequências para a electio iuris ou dando origem ao forum ou law shopping), implica conhecimento do relativismo jurídico ${ }^{115}$.

À idéia de relativismo está associdada a noção de complexidade, assim como à idéia do universalismo está associada a simplicidade. A simplicidade "sur laquelle était fondé le droit de facture "moderne,", ressalta ARNAUD, "c'est la croyance dans la possibilitè de l'établissement d'une sorte de catéchisme des règles de droit, qui seraient de la sorte rendues à connaître par tous les indivus, universellement de par le monde"116. Consequiência dessa simplicidade é o dogma da segurança jurídica, resultado da idéia de perpetuidade das leis. O direito pós-moderno afasta a presunção da simplicidade e retoma a complexidade.

FARALLI destaca que a sociedade atual é caracterizada pela insegurança e instabilidade em razão das rápidas transformações, da enorme mobilidade e da contínua diversificação de grupos sociais, que não compartilham valores comuns e têm interesses distintos. Novas relações econômicas surgem e demanam novos institutos e relações jurídicas ${ }^{117}$, de modo a intensificar o papel criador do juiz. Este fato, somado à proliferação de legislação especial e de normas regulamentares, torna difícil atribuir ao direito um caráter de certeza, afetando os alicerces da noção de segurança ${ }^{118}$.

Ainda segundo ARNAUD, a concepção pós-moderna do direito parte da premissa de que as categorias teóricas estabelecidas devem ser interdisciplinares e são provisórias, hipotéticas e instrumentais. Propõe generalizar a dialética do pensamento e da ação, sugerindo a implementação de políticas jurídicas negociadas em substituição à ordem imposta. ARNAUD conclui que o paradigma pós-moderno é, assim, "la pierre

\footnotetext{
${ }^{115}$ M. R. FerRAReSe, Le istituzioni della globalizzazione..., pp. 42 e ss. Vide A. C. CUTLER, Private Power..., pp. 202-3. Vide sobre holdings, law e forum shopping F. GALGANO, La globalizzazione ..., pp. 83 e ss. e 157 e ss., E. LoQUin, Où en est la lex mercatoria..., p. 43.

116 A. ARNAUD, Entre modernité et mondialisation..., p. 284. A presunção de possibilidade de conhecimento por todos decorre da idéia, segundo o jurista francês, de que "sur toute la surface de la planète, un indivu égale un autre indivu, et que les règles fondamentales de conduite valables pour l'un paraissent valable nécessairement valable pour l'autre".

${ }^{117}$ M. R. FERRARESE, Diritto sconfinato - inventiva giuridica e spazi nel mondo globale, Roma-Bari, Laterza, 2006, p. 101, afirma que "l'incompletezza che si vorrebbe attribuire alla lex mercatoria come il segno di un cammino ancora incompiuto sulla strada della giuridicità appare invece un tratto che senga un po' tutto il diritto, sia esso nazionale, internazionale, sovranazionale o transnazionale, se pure in forme e consistenze diverse".

${ }^{118}$ C. FARALli, Certezza del diritto o diritto alla certezza?, in Materiali per una Storia della Cultura Giuridica, v. 27, n. 1,1997, p. 91 e pp. 101 e ss.
} 
angulaire de tout um système de pensée fondé sur l'idée du 'pluriel', du 'négocié', du 'complexe", ${ }^{\prime 119}$.

É interessante o paralelo sobre a passagem do direito à pós-modernidade desenvolvido por OsT. Relaciona Júpiter ao direito moderno, hierárquico, piramidal, que se exprime no imperativo e prefere a natureza do proibido. Denomina tal modelo de “direito jupiteriano". Ao direito pós-moderno, OsT relaciona a figura de Hermes ${ }^{120}$ (Mercúrio), filho de Maia e Zeus (Júpiter), de quem era seu mensageiro e que tinha asas no chapéu e nas sandálias, deus do comércio. Sempre em movimento, Hermes está no céu, na terra e no inferno ${ }^{121}$. Ocupa espaços vazios e os conecta. Deus dos mercadores, preside as trocas; deus dos navegadores, ultrapassa as passagens desconhecidas. Segundo Ost, Hermes é, assim, o "médiateur universel, le grand communicateur. Il ne connait d'autre loi que la circulation des discours...”. Assim, de acordo com o jurista francês, se a Júpiter cabe a montanha ou a pirâmide, a trajetória que Hermes desenha é aquela de uma rede - uma multiplicidade de pontos de inter-relação ${ }^{122}$. OsT, assim, afirma que o direito é logos, discurso, sentido em suspenso ${ }^{123}$.

\footnotetext{
${ }^{119}$ A. ARNAUD, Entre modernité et mondialisation..., pp. 289-90.

${ }^{120}$ F. Ost, “Jupiter, Hercules, Hèrmes..., pp. 244 e ss. e T. BLulfinch, The Age of Fable, trad. port. de David Jardim Júnior, O livro de ouro da mitologia - história de deuses e heróis, $5^{\mathrm{a}}$ ed., Rio de Janeiro, Ediouro, 1999. Hermes era também deus da luta e também dos ladrões. Sobre este último aspecto, F. OST (pp. 266 e ss.), ao abordar a dimensão ética e de legitimidade do modelo e analisar se o modelo implicaria exploração, injustiça e etc. Além da figura de Júpiter e Hermes, Ost sugere um terceiro modelo, o de Hércules, baseado no direito judiciário, refletindo uma pirâmide invertida ou um funil (a qual o jurista francês relaciona, por exemplo, a sociological jurisprudence).

${ }^{121}$ É comum a caracterização da ubiqüidade do direito na sociedade pós-industrial. A. C. CUTLER, Private Power..., p. 18, por exemplo, observa que "the development of new commercial law and codes and specialized legal processes for dispute settlement under these regimes, as well as legal developments in the areas of investment, finance, and monetary relations, are resulting in the ubiquity of law, domestically, internationally and transnationally. Lawyers tend to analyze these developments in terms of the 'globalization of law', while international relation scholars address the 'legalization of world politics"”.

${ }^{122}$ F. OST, “Jupiter, Hercules, Hèrmes..., pp. 244-5.

${ }^{123}$ F. Ost, “Jupiter, Hercules, Hèrmes..., p. 263. Desse modo, para OsT, o direito "il s'articule entre les choses: entre la règle ... e le fait, entre l'ordre et disordre, entre la lettre et l'espirit, entre la force et la justice. Dialetique, il est un par l'autre, paradoxal, il est un et l'autre". Por isso, para ele, apenas uma teoria lúdica ou do jogo poderia fornecer suporte teórico necessário. As cinco principais características dessa teoria são (pp. 264-5): (i) o jogo é seu próprio movimento; ele desenha seu próprio espaço; (ii) número indefinido de jogadores, cujos papéis não estão programados, com a possibilidade de participação em níveis distintos e em outros jogos (econômicos e políticos, por exemplo); (iii) mais importante, o jogo combina, em proporção variável, regras e álea; convenção e invenção, abertura e fechamento; (iv) permite a distinção entre o pólo simbólico (jogo como representação) e o pólo utilitarista (jogo com estratégia); e, por fim, (v) permite a distinção entre o interno e o externo, o limite e o "fora do jogo", a fronteira que separa o sistema e seu meio-ambiente. Segundo M. R. FERRARESE, Le istituzioni della globalizzazione..., p. 102, o direito pode ser entendido como "gioco giuridico, de forma que "il diritto non esiste in astratto se non come schema di possibilità, saranno i giocatori che, di volta in volta, gli danno una esistenza specifica". G. TEUBNER, Breaking Frames..., pp. 24 e ss., não compartilha da teoria formulada por Ost.
} 
Essa concepção pós-moderna do direito, espelhada na figura de Hermes tal qual descrita acima, é um bom indicativo do caminho a ser percorrido pelo direito e das funções que deve assumir.

Recorde-se, uma vez mais, que a atualidade é moldada pela transnacionalidade das relações econômicas (com a circulação do conhecimento e da informação), sociais e políticas atuais e pela existência de espaços imateriais, "vazios", criando um contexto plural e horizontal e uma dialética centro/periferia. FERRARESE assinala que as teorias dos custos de transação (especialmente os de informação) faz com que os mercados acentuem sua característica de "estruturas de comunicação", sendo o direito o mais importante entre os instrumentos de comunicação com os quais os mercados contam, de modo que, indica FERRARESEm são formados dialéticos jurídicos ${ }^{124}$.

O direito, como resultado desses fatores, está sempre em movimento, não podendo ser considerado um produto acabado (work in progress), mas em constante desenvolvimento, construção. Por isso, observa FERRARESE, o direito não pode ser reduzido a um momento normativo e, além disso, não pode ser entendido como procedimento, isto é, como seqüência de etapas formais - o que implica, também, que a forma de legitimação tradicional (o procedimento) de certa forma é modificada ${ }^{125}$.

Em vez de procedimento, processo. O direito estabelece, desde a sua gênese até sua aplicação e transformação, relações (que TEUBNER denomina de acoplamentos) com a política, com a economia e, principalmente, com a sociedade civil - constituindo os regimes privados ${ }^{126}$.

Para tanto, é importante que o direito se mostre instrumento adequado para realização de diálogos e estabelecimento de comunicação e consensos entre os diversos atores sociais, em níveis locais, regionais, infra-estatais ou transnacionais.

\subsection{Direito transnacional}

O termo direito transnacional é geralmente atribuído a JESSUP que, na década de cinquienta do século passado, cunhou como direito transnacional aquele regula as ações

\footnotetext{
${ }^{124}$ M. R. FERRARESE, Le istituzioni della globalizzazione..., p. 69.

${ }^{125}$ M. R. FERRARESE, Le istituzioni della globalizzazione..., pp. 141 e ss.

${ }^{126}$ G. TEUBNER, Direito, Sistema e Policontexturalidade..., pp. 237 e ss.
} 
ou eventos que transcendem as fronteiras nacionais, incluindo tanto direito privado quanto direito público ${ }^{127}$.

O direito da sociedade pós-industrial é também transnacional. Mas não no sentido "clássico" da expressão. GOLDMAN afirma que, tal como concebido por Jessup, direito transnacional ainda está associado à idéia de direito estatal ou inter-estatal (ou internacional) e não reflete alguns fenômenos jurídicos como a nova lex mercatoria ${ }^{128}$ ou a lex electronica. De acordo com SchmitThoff, "it is, therefore, wrong to attribute character of international or supranational law to international trade law (entendido como nova lex mercatoria)... the best way to describe the peculiar character of international trade law is to refer to it as transnational law" ${ }^{\prime 29}$.

Assim, direito transnacional não é direito nacional, assim como não é supranacional. Também não é internacional, que é baseado na mesma lógica da existência de fronteiras e que, sob esta perspectiva, implica a idéia de alargamento de jurisdição além do território por acordo entre os Estados. $\mathrm{O}$ que distingue o transnacional do nacional e do internacional não é o critério espacial ${ }^{130}$.

Por um lado, os fluxos migratórios, que são uma característica da sociedade pósindustrial, fazem com que muitos, como os trabalhadores migrantes, os nômades e os membros de - denomina BERMAN - uma elite profissional e empresarial transnacional, "live a life of border crossings", de forma que a diferença cultural não mais possa ser baseada no território. Formam-se, assim, ao lado das comunidades baseadas em território, as comunidades de interesse ${ }^{131}$.

\footnotetext{
127 P. C. JESsup, Transnational Law, trad. port. de Carlos Ramires Pinheiro da Silva, Direito transnacional, Rio de Janeiro, Fundo de Cultura, 1956, p. 2.

${ }^{128}$ B. Goldman, The applicable law..., p. 114. A. C. CUTLER, Private Power..., pp. 263 e ss., recorda que B. de. S. Santos (Toward a New Common Sense - Law, Science, and Politics in the Paradigmatic Transition, 1995) identifica sete formas de relações jurídicas transnacionais: direito estatal transnacionalizado, direito da integração regional, lex mercatoria, direito das pessoas em movimento (movimentos migratórios), direito infra-estatal transnacional, direito cosmopolita (gerado por ONGs, Estados, OIs, etc.), e direitos humanos (jus hummanitas ou the common heritage of mankind).

${ }^{129}$ C. SCHMITTHOFF, The Unification of International Trade Law, in Select Essays on international trade, Chia-Jui Cheng (ed.), Dortrecht, Boston, London, Martinus Nijhoff Publishers e Graham\&Trotman, 1988, p. 234. A. ARNAUD, Entre modernité et mondialisation..., p. 25, sublinha que "si l'on voulait se référer à la réalité de la nation dans ce processus d'échanges, il conviendrait plutôt de parler de 'transnationalisation', au sens où certains flux passe d'une nation à l'autre sans que les échanges relévent ... du droit national ni du droit international".

${ }_{130}$ M. R. FERRARESE, Il diritto al presente..., p. 166.

131 P. S. BERMAN, From international law..., pp. 512-5. B. GoldMAN, La lex mercatoria dans les contrats et l'arbitrage internationaux - réalité et perspectives, in Journal du Droit International, 1979, p. 487, afirma que as regras da nova lex mercatoria são anacionais (melhor seria transnacionais, neste caso) porque não são fundadas em sistemas jurídicos nacionais, mas na consciência da sociedade internacional de comerciantes ou societas mercatorum.
} 
Por outro lado, salienta VIRALLY, embora as relações econômicas internacionais sejam submetidas em uma larga escala aos direitos nacionais - já que elas não se realizam no $\operatorname{ar}^{132}$ - e estejam, portanto, submetidas à soberania de um ou mais Estados, essas relações têm vínculos com diversos Estados (ou ordens jurídicas territoriais), de modo que se torna muito difícil, talvez impossível, para apenas uma ordem jurídica querer submeter todos os seus aspectos a um único direito e território ${ }^{133}$.

Um dos efeitos da conexão dessas relações econômicas internacionais com uma pluralidade de Estados é a intensificação do forum shopping e do law shopping, que podem ter efeitos positivos do ponto de vista de previsibilidade e adequação da resposta juridicional (seja do tribunal estatal ou arbitral), mas podem também ter efeitos negativos, quando utilizados como meio para afastar a aplicação de regras de ordem pública que seriam naturalmente aplicadas ao caso ${ }^{134}$.

É com base nessas implicações da sociedade pós-industrial, em rede, constituída de uma multiplicidade processos comunicativos, que se faz necessário conceber um direito transnacional baseado não mais em um espaço físico, geográfico, mas em um espaço jurídico.

O espaço transnacional é, ressalta FERrARESE, "quello mobile e cangiante disegnato e ridisegnato in continuazione dai soggeti che lo percorrono specialmente con le loro comunicazioni: comunicazioni sociali, giuridiche, politiche, economiche ecc."135. Segundo a socióloga do direito, trata-se de um espaço inventado mais pelo mercado e pela tecnologia do que pela política, cujos limites e fronteiras são sempre incertos e móveis, que é substituído pela própria comunicação. Mais do que dar respostas positivas, conclui FERRARESE, esse espaço constrói “un ambiente giuridico capace di far

\footnotetext{
${ }^{132}$ Ainda que a criação de espaços virtuais, como o da internet, torne, como observa PELLET, La lex mercatoria "tiers ordre juridique"? - remarques ingenues d'un internationaliste de droit publique, in C. LEBEN; E. LOQUin; M. SALEM (org.), Souveraineté étatique et marchés internationaux à la fin du 20ème siècle, à propos de 30 ans de recherche du CREDIMI - mélanges en l'honneur de Philippe Kahn, Paris, Litec, 2000, pp. 57-8, a conexão dos contratos consubstanciando essas relações a um território mais mais difícil, porque sua execução é, por essência, não localizável. Mesmo assim, esses contratos sempre estarão sujeitos a determinadas regras de um ou mais Estados.

133 M. VIRALly, Un tiers droit? - refléxions theoriques, in Droit des relations economiques internationales - etudes offertes a Berthold Goldman, Paris, Litec, 1982, p. 377.

${ }^{134}$ F. Galgano, La globalizzazione ..., pp. 83 e ss., E. LoQUIN, Où en est la lex mercatoria?..., p. 43.

135 M. R. FERRARESE, Il diritto al presente..., p. 166. A autora, Diritto sconfinato..., p. 65, destaca que "è chiaro che relazioni dotate di carattere economico, culturale, sociale ecc. sono sempre esistite e hanno sempre travalicato i confini nazionali, disegnando liberamente flussi di comunicazione più o meno stabiliti: il diritto, tuttavia, estava escluso di questa libertà di passare attraverso i confini e gli attraversamenti restavano soggetti alle regole del diritto internazionale pubblico o privato".
} 
dialogare sui diritti soggetti, gruppi, popoli, culture, tradizioni, a dispetto della diversità e, talvolta, persino a dispetto della loro presunta inconciabilità"136.

Nesse espaço, as empresas multinacionais, por muitos anos baseadas em uma organização política territorializada, passam também a ser qualificadas como transnacionais $^{137}$.

FERRARESE também aponta que, ao menos por ora, "solo l'economia è atrezzata per 'abitare' questo spazio, mentre le istituzioni politiche non lo sono", causando um divórcio parcial entre instituições políticas e jurídicas, já que, de certa forma, as primeiras estão limitadas a seu território, ou território alargado, seja supra ouinternacionalmente, ao passo que as jurídicas não - basta notar o papel do contrato no direito pós-industrial ${ }^{138}$.

CUTLER, por exemplo, aponta para uma questão de responsabilização das empresas transnacionais, já que os Estados raramente terão a vontade política de responsabilizar-se por elas, mesmo porque com a utilização das holdings, das relações entre empresas do mesmo grupo, do law e do forum shopping, os Estados não têm meios para garantir a nacionalidade dessas empresas ${ }^{139}$.

FERRARESE adverte, porém, que "il linguaggio dei diritti, in quanto transnazionali, non è ancora un luogo per risposte politiche o per legami comunitari: è solo una premessa per tutto questo, una premessa basata sulla possibilità dell'incontro e della comunicazione" ${ }^{, 140}$.

A existência de um tal espaço transnacional, com disjunção entre economia e política, e dos respectivos atores transnacionais e direito transnacional têm sérias implicações do ponto de vista político e de legitimidade democrática ${ }^{141}$.

\footnotetext{
${ }_{136}^{136}$ M. R. FERRARESE, Il diritto al presente..., p.166-9.

${ }^{137}$ M. R. FerRARESE, Il diritto al presente..., p.167. A autora destaca que "le cosidette 'multinazionale' sono smbrate a lungo compatibili con questo tipo di organizzazione: non a caso ... il riferimento era ancora alle 'nazioni'. Ma esse erano, in realtà, le prime manifestazioni di una capacità delle imprese di svincolarsi dal territorio statale e di determinare una diversa spazialità. Perchè si passasse alle imprese 'transnazionali', occorreva quella crescita della capacità di movimento dell'economia che è stata data sia dalle nuove tecnologie elletroniche, sia dalla liberalizzazione finanziale, la quale ha finito per sottrarre in gran parte la moneta al controllo degli Stati".

${ }_{138}$ M. R. FERRARESE, Il diritto al presente..., pp.167-9. Sobre o papel do contrato, vide item 2.7 abaixo.

139 A. C. CutLer, Private Power..., pp. 202-3. Vide sobre holdings, law e forum shopping F. Galgano, La globalizzazione ..., pp. 83 e ss. e 157 e ss., E. LoQuin, Où en est la lex mercatoria..., p. 43 e M. R. FERRARESE, Le istituzioni della globalizzazione..., pp. 42 e ss.

${ }_{140}$ M. R. FERRARESE, Il diritto al presente..., pp. 169.

${ }^{141}$ Os efeitos negativos serão analisados, sob a perspectiva da nova lex mercatoria, no item 4.1.4.
} 


\subsection{As autoridades privadas}

A transnacionalidade do direito, com fronteiras menos sólidas e o aparecimento de novos atores expressando necessidades e interesses, conduz a uma separação menos nítida entre as esferas pública e privada.

CUTLER observa que a unificação, inicialmente concebida o século XIX como estratégia para cooperação internacional está se desenvolvendo como estratégia de competição internacional consistente com a transição do Estado de bem-estar social (welfare State) para o Estado competidor (competition state), em que o Estado deve agir cada vez mais como um market player. Esse movimento, segundo CUTLER, "is blurring the distinction between public and private authority because states in their public capacities are negotiating laws that govern commercial transactions which have traditionally been regarded as private by liberal theories of international political economy and of international law, while private actors are increasingly participating in the settlement of matters that were previously regarded as part of public domain"142.

Por esta razão, faz-se necessária a reavaliação do Estado como única fonte de produção do direito e, consequentemente, a reavaliação das autoridades privadas (como fontes legítimas de produção do direito).

CUTLER observa que a tendência dominante - ainda que inadequada - da teoria política é a de considerar a questão das autoridades no contexto da esfera pública e não da esfera privada. Assim, para ela, "both law and politics are dominated by unhistorical and state-centric theories..."143. O caráter público de autoridade muitas vezes é constituído pela distinção entre atividades privadas e públicas, distinção esta que não reflete a realidade atual, como destacado acima ${ }^{144}$.

SACCO sublinha que "finché il diritto privato è consuetudinario non ha bisogno di giustificazione, bastando al fine il consenso di coloro che lo praticano. ... Allorché il diritto pubblico ha messo le mani sul diritto privati, la legittimazione propria del diritto pubblico si è estesa al diritto privato" $" 145$.

\footnotetext{
142 A. C. CUTLER, Private Power..., p. 185.

143 A. C. CuTLER, Private Power..., pp. 61-2.

144 A. C. CUTLER, Private Power..., p. 65. CUTLER (p. 69) comenta ainda que "the appearance of the separations of the public and private spheres and economics and politics in the nineteenth century suggests that notions of authority that are defined by these separations are of rather limited historical significance".

${ }^{145}$ R. SACCO, Antropologia giuridica - contributo ad una macrostoria del diritto, Bologna, Il Mulino, 2007, p. 245.
} 
CUTLER ressalta que, historicamente, a constituição de autoridade política é um arranjo envolvendo tanto autoridades estatais (ou oficiais) e não estatais. A noção de autoridade invoca um senso coletivo ou público porque dela resulta a obediência dos privados. Mas, ressalta CUTLER, autoridade se distingue de coerção porque envolve um grau de reconhecimento de um sujeito de que outro tem direito à obediência. Esse reconhecimento, público (no sentido coletivo, e não estatal), é essencial para a concepção de autoridade política com legitimidade para emanar regras ${ }^{146}$.

Para a autora britânica, os requisitos de designação, reconhecimento e aceitação pública da autoridade fazem com que a autoridade seja uma construção social, ou seja, é resultado de um arranjo normativo entre os membros da sociedade. Por isso, a autoridade deve ser concebida menos como entidade do que como efeito, conforme o contexto social relevante ${ }^{147}$.

SACCO, como observado, aponta que o consenso entre os destinatários das regras é suficiente como fonte de legitimação do direito e, portanto, como reconhecimento da autoridade privada. CALLIGAN também considera a autoridade como uma expressão social $^{148}$.

BERMAN aponta que o viés transnacional da sociedade pós-industrial envolve a articulação de regras jurídicas, mesmo sem o poder literal (ou oficial) para compelir a aplicação (enforce) dessas normas. Entretanto, afirma, "the mere articulation of such norms may often have important, though less obvious persuasive power" ${ }^{\text {"149 }}$, o que leva ao questionamento da definição do direito pelas sanções ${ }^{150}$. BERMAN, a título ilustrativo, recorda que entidades profissionais relacionadas ao comércio internacional, que estabelecem regras e padrões privados, têm papel essencial na criação espontânea de padrões que se tornam regras aplicáveis à indústria correspondentes ${ }^{151}$.

Assim, em conclusão, CUTLER, destaca que "one of the most significant transformations in world order today involves a pluralization of authority relations and multiplicity of cross-cutting and overlapping networks of authority operating

\footnotetext{
${ }^{146}$ A. C. CUTLER, Private Power..., pp. 62-3.

147 A. C. CutLer, Private Power..., pp. 64-5.

${ }^{148}$ D. J. CAlligan, Law in Modern Society, New York, Oxford University Press, 2007, pp. 183-6, afirma que um sistema jurídico resulta da "combination of system of rules, an institutional base with officials, and the capacity for enforcement" e que "it is the people assembled, whether literally or metaphorically, who have authority to settle matters of social relations, to determine their legality or illegality. The assembly becomes unworkable in more complex societies and is replaced by rules and officials".

${ }^{149}$ P. S. BERMAN, From international law..., p. 529.

${ }^{150}$ Vide, a respeito da nova lex mercatoria, item 4.1.3.2.

${ }^{151}$ P. S. BERMAN, From international law..., p. 529.
} 
subnationally, nationally, regionally, and transnationally", autoridade esta que é exercidada por uma variedade de meios, desde os mais informais até aqueles altamento institucionalizados ${ }^{152}$.

FERRARESE aponta que não é possível elencar de forma exaustiva os atores que produzem regras jurídicas - e, portanto, daqueles que exercem autoridade - já que, na sociedade pós-industrial esse rol sofreu mudanças não só quantitativas, mas qualitiativas, justamente em razão de, mesmo como atores privados, terem relevância pública, institucional ${ }^{153}$.

A tecnocracia tem um papel interessante nesse contexto, como se verá a respeito da nova lex mercatoria ${ }^{154}$.

Mais importante do que identificar a existência das autoridades privadas, é refletir a respeito de sua contextualização na sociedade pós-industrial e os modos pelos quais opera $^{155}$.

Em razão da reconfiguração da noção de autoridade, com o reconhecimento de autoridades privadas e conseqüente enfraquecimento da distinção entre esferas pública e privada, cabe avaliar os impactos às categorias do direito privado e público e a análise,

\footnotetext{
152 A. C. CUTLER, Private Power..., p. 70. A autora critica a idéia de uma global authority unificada: "these conditions of authority are problematic, particularly when they are articulated in the context of global political economy. The nature of the social context for global authority is not obvious. Clearly authority presupposes some sort of 'unity of the social sphere'. However, the character of this unity is especially troubling in the global context", onde há ausência de um "orderer". Ela aponta que "the presumption of social unity slides easily and uncritically into presumption of social consensus and/or state consent as prerequisites for constructing authority. The problem lies in identifying the origin and scope of this social unity and the public sphere". Com base em Michael Mann, a autora britânica (p. 65) conclui "societies are never unitary, but are 'constituted of multiple overlapping and intersecting sociospatial networks of power"”.

153 M. R. FERrARESE, Le istituzioni della globalizzazione..., p. 102. Segundo W. KONRADI; H. FIXFIERRO, Lex mercatoria in the mirror of empirical research, in Sociologia del Diritto, v. 32. n. 2-3, pp. 222-3, "institutionalization implies the existence of a more or less dense network of organizations and associations which accomplish several functions. First, they promote the building of connection and links between merchants within the industry. Second, they represent the collective interests and autonomy of the merchant community. Third, they elaborate specific policies and standards to which members of the trade must conform. And finally, they provide formal or informal mechanisms for inducing compliance with such internal policies and standards, as well as for the settlement of disputes".

${ }^{154}$ Vide itens 3.3, 4.1.4 e 4.2 .

155 A. C. Cutler, Private Power..., pp. 24-5 e 68-9, nota a existência de relações assimétricas de força/poder a que as autoridades privadas, por estratégia do liberalism, dão causa: "liberalism obscures this asymmetry by positing a consent-based social unity which tends to equalize relations between members of society... Furthermore, liberalism also obscures the fact that social unity may be very limited in scope... The notion that consent somehow creates an equal playing field as between the governors and the governed obscures the fundamental asymmetry in power relations between them and risks overstating the social unity that constitutes political authority... But as Antonio Gramsci (1971:160) notes, the distinction between civil society and the state is 'not an organic one... it is merely methodological': But since in actual reality civil society and the State are one and the same, it must be clear that laissez-faire too is a form of State 'regulation', introduced and maintained by legislative and coercive means".
} 
ainda que breve, da noção de governança global, muitas vezes apresentada como solução para a fragmentação da esfera pública.

\subsubsection{A dicotomia entre direito privado e público}

As categorias direito privado e direito público historicamente nunca se distinguiram em contornos tão nítidos como nos últimos dois ou três séculos. Além disso, essa contraposição entre um ramo e outro do direito também não é universal, sendo mais característica da sociedade ocidental e, mais especificamente, dos países cujo direito é de tradição romano-germânica.

SACCo ensina que, assim como outros, os habitantes do deserto de Calaari ou da bacia do alto Orinoco não conhecem a distinção entre direito privado e direito público. Mas são sociedades de poder difuso. O comparatista italiano, então, revela que quanto mais enraízado um poder político centralizado, mais se instaura a dicotomia. Mesmo assim, nos impérios desenvolvidos no Egito, China, México, Perú e Mesopotâmia a divisão não se desenvolve em sua integralidade. SACCO afirma, desse modo, que "la società a potere diffuso conosceva un diritto spontaneo, la società a potere centralizzato ha sovraposto a questo diritto spontaneo un diritto di origine autoritativa" ${ }^{\text {"156 . }}$

SACCO conclui que o direito público nasceu como nasceu o Estado ${ }^{157}$. No direito tracional chinês, porém, o direito privado não era estatal. O direito popular não invocava nenhuma justificação oficial. A legitimação era o consenso geral dos interessados.

No direito romano, DAVID e SACCO recordam, existia um direito público, mas muito rudimentar, ao qual não se dava atenção por ser inútil e perigoso. A atenção era voltada ao desenvolvimento do direito privado e os mecanismos que garantiam sua aplicação, de modo que direito público e privado são, em Roma, metade de um sistema único indivisível ${ }^{158}$.

Já a Idade Média até conhece a distinção entre direito público e privado, mas a descontrói. O poder político de um rei ou do parlamento, relata SACCO, era regido pelo direito público. $\mathrm{O}$ direito que regulava as relações entre os comerciantes era privado. Mas, salienta o comparatista italiano, "i diritti e poteri dei membri delle classe ammesse

\footnotetext{
${ }^{156}$ R. SACCO, Antropologia giuridica..., pp. 238 e ss.

${ }^{157}$ R. SACCO, Antropologia giuridica..., p. 240.

${ }^{158}$ R. DAVID, Les Grands Systèmes..., p. 85 e R. SACCO, Antropologia giuridica..., pp. 241-2.
} 
alle prestazioni e ai privilegi feudali appartengono a un'area i cui caratteri non sono ne nettamente privati, ne nettamente pubblici" ${ }^{159}$.

Mas, pelos ideais iluministas, o Estado deve ser organizado conforme a razão e, principalmente, surge a necessidade de garantia eficaz dos direitos naturais dos indivíduos contra os abusos do poder ${ }^{160}$.

A revolução francesa, suprimindo os direitos feudais, reestabelece a oposição entre direito público e direito privado, inserindo princípios inteiramente novos desenvolvidos nos séculos XIX e $\mathrm{XX}^{161}$.

A distinção entre direito público e privado, comum nos países da família romano-germânica, "se baseia sobre uma idéia que... as relações entre governantes e governados dão lugar a problemas específicos, e tornam necessárias normas diversas das que regulam as relações entre as pessoas privadas, porque o interesse geral e os interesses particulares não podem ser pesados na mesma balança" ${ }^{\text {"162 }}$.

Mesmo assim, essa distinção não é universal. Nos sistemas socialistas, todo direito era público. $\mathrm{O}$ direito inglês não reflete a distinção entre direito privado e público comum nos países da família romano-germânica ${ }^{163}$.

A redefinição dos limites espaço-temporais altera a vida das pessoas e o papel do Estado e, com isso, as esferas de relevância pública também são alteradas. A reorganização das fontes do direito e a revalorização das autoridades privadas ou não Estatais têm impacto relevante nas categorias de organização do direito.

CUTLER aponta que, como expressão de um direito transnacional típico da sociedade pós-industrial, "transnational merchant law is also blurring the boundary between public and private domains as state elites participate in delocalizing law and dispute settlement, thus narrowing the jurisdiction and powers of the public sphere and broadening those of private sphere" 164 .

\footnotetext{
${ }^{159}$ R. SACCO, Antropologia giuridica..., p. 243. A. C. CUTLER, Private Power..., p. 139, ao retratar o antigo ius mercatorum, comenta que "the rather sharp contrast between merchant autonomy in international commercial transactions and the intensity with which local commercial exchanges were regulate to protect consumers and regulate markets anticipated what were to become distinctions between domestic/foreign commercial relations and the public/private spheres".

${ }^{160}$ R. DAVID, Les Grands Systèmes..., pp. 85-6.

${ }^{161}$ R. SACCO, Antropologia giuridica..., p. 244 e R. DAVID, Les Grands Systèmes..., pp. 85-6. A. C. CUTLER, Private Power..., p. 141, afirma que "with the development of a system of territorial-based sovereign states, and with the movement from feudalism to capitalism, the public/private distinction came to be firmly established".

${ }^{162}$ R. DAVID, Les Grands Systèmes..., p. 85.

${ }^{163}$ R. SACCO, Antropologia giuridica..., p. 238. Para SACCO (p. 238), direito privado e não privado são categorias estranhas ao problema da aplicação do direito.

${ }^{164}$ A. C. CUTLER, Private Power..., p. 182.
} 
Nesse contexto, em que o poder é mais difuso, a dicotomia público-privado (e também a de direito internaiconal público e direito internacional privado) faz menos sentido. A razão para tanto, segundo BERMAN, é que a distinção está associada a um direito inter-estatal (state-to-state) ${ }^{165}$.

BoBBIO comenta que tanto o termo direito privado quanto direito público "é suscetível, por influência do seu significado historiográfico e axiológico, de ser ampliado até conotar não mais uma só das duas partes, mas todo o universo... empurrando o outro termo para fora do universo...". Para o jurista italiano, o caráter ideológico da distinção não é imanente à dicotomia, mas depende da "carga valorativa atribuída aos dois termos", conforme se queira prevaleça uma ou outra. Assim, BoBBIO salienta que essa classificação comporta carga valorativa relevante, tanto positiva quanto negativa, conforme inclinação publicista ou privatista daquele que usa o termo. Ao longo da história, alternou-se a supremacia de um e de outro. De acordo com BoBвIO, quando a perspectiva publicista prevalece, como no caso da modernidade, o que se denomina de direito privado é, no fundo, direito público, eis que sujeito ao Estado $^{166}$.

Ao analisar a dicotomia entre direito público e privado, TEUBNER coloca dois problemas: (i) como escapar da dicotomia público/privado e obter uma pluralidade de autonomias privadas distintas e (ii) como transformar o direito privado em um direito constitucional aos diversos sistemas de private governance.

Em substituição a essa dicotomia, o jurista alemão sugere a noção de policontexturalidade, com advento de "uma pluralidade de setores sociais reproduzindose, por sua vez, no direito". Para tanto, cumpre liberar o direito privado da politização e economização, distanciando-se tanto do público quanto do privado ("o direito privado não pode simplesmente equiparar-se com a juridificação da esfera econômica" ${ }^{\text {"167}}$ ).

Pensando a partir de problemas decorrentes da privatização de serviços públicos, TEUBNER anota que, especialmente quanto "aos conflitos entre atividades sociais e seus novos regimes econômicos, o direito privado deverá desenvolver uma grande medida de

\footnotetext{
${ }^{165}$ P. S. BERMAN, From international law..., pp. 518 e ss., aponta que "the boundary between public and private international law, though often treated as distinct, has been blurred from its inception", sendo uma distinção artificial. "Thus, conflicts law and international business transactions have become a staple of state-to-state relations, and non-state or private actors have taken increasingly important role in the articulation and enforcement of international standards".

${ }^{166}$ N. BobBIO, Da Estrutura à função - novos estudos de teoria do direito, São Paulo, Manole/Bovespa, 2006, pp. 141 e ss. Na análise dessa dicotomia, BoBBIo (pp. 156-7) identifica o direito privado com direito natural, consuetudinário, espontâneo, dos particulares.

${ }^{167}$ G. Teubner, Direito, Sistema e Policontexturalidade ..., pp. 237-8.
} 
responsividade, tanto no direito material quanto no direito processual". Assim, argumenta o jurista alemão, "o direito privado deve impor normas fundamentais de outros sistemas sociais às transações econômicas". TEUBNER conclui que "a privatização levará a uma penetração maciça de princípios de direito público no regime de direito privado" $" 168$.

Em razão da criação dos regimes privados por meio dos diversos sub-sistemas, TEUBNER identifica dois fenômenos: fragmentação e hibridização. O primeiro "designa ...a reação a uma multiplicidade de âmbitos de autonomias sociais, na medida em que estejam acoplados apenas frouxamente a processos econômicos. Hibridização, por sua vez, consiste na reação a um acoplamento firme à economia" ${ }^{\text {"169 }}$.

DELMAS-MARTY também imputa como resultado da globalização, especialmente econômica e financeira, um direito privado que se politiza e se publiciza e um direito público que se privatiza ${ }^{170}$.

Na sociedade global, com a reorganização das fontes do direito e convivência de novas e velhas fontes, a dicotomia público/privado faz menos sentido. Instala-se, ao contrário, dialética formal/informal, com um quadro jurídico mais variável, cada vez mais privado ${ }^{171}$. Mas o direito privado atinge esferas de relevância pública ou coletiva, transcendendo o interesse dos indivíduos.

\subsubsection{Governança}

Reputa-se, como se verá ${ }^{172}$, que, em um contexto em que o direito não provém necessariamente de instituições políticas, mas também de diversas camadas e grupos sociais (autoridades privadas), sem que a participação dos destinatários ou a representatividade das autoridades seja adequada, o direito na sociedade pós-industrial sofre de um déficit democrático, o que pode levar a distorsões e desequilíbrios a partir de relações assimétricas baseadas no poder (econômico ou não).

Segundo uma resolução adotada em 26.6.2002 pelo Consultative Committee of the European Economic Area (EEA-CC) "government represents the classic form of state government based upon an institutional hierarchy and policy of rules and

\footnotetext{
${ }^{168}$ G. TEUBnER, Direito, Sistema e Policontexturalidade..., pp. 47-8, 235 e 252.

${ }^{169}$ G. Teubner, Direito, Sistema e Policontexturalidade..., p. 255.

${ }^{170}$ M. DELMAS-MARTY, Les forces imaginantes du droit..., p. 324.

${ }^{171}$ M. R. FERRARESE, Le istituzioni della globalizzazione..., pp. 52 e ss.

${ }^{172}$ Vide, a respeito da nova lex mercatoria, item 4.1.4.
} 
regulations", ao passo que "governance is a form of government where groups or individuals from different institutions, organisations, organs, enterprises and levels work in networks and in public and private partnership. On the basis of dialogue, negotiations and bargaining procedures, they construct agreements and contracts that form the decisive framework for future decision-making" ${ }^{\text {"173. }}$.

De acordo com CASUCCI, para contrastar a crescente desconfiança em relação às instituições econômicas internacionais, a introdução de uma global governance, que, para o jurista italiano, compreende um complexo de normas introduzidas por acordos bilaterais e multilaterais e implementadas em níveis distintos (local, nacional e internacional), a fim de regulamentar fluxos econômicos realizados no mercado mundial $^{174}$.

Segundo Delmas-MARTY, a governança global seria mais um ideal, um sonho, do que propriamente uma prática implementada. Para a jurista francesa, "elle apparaît donc moins comme un modèle stabilisé que comme un mouvement, une dynamique de transformation qui multiplie les interfaces, lieux de passage pour d'improbables rencontres, où se croisent sans s'unir le public e le privé, le droit dur et le drot mou"175.

PICCIOTTO destaca que a noção de governança é normalmente associada à noção de rede (netowrk) de certa forma captura a reorganização das fontes do direito, afastando a idéia de que as regras jurídicas se enquadram em "relatively clear categories and hierarchies, with international law binding states, and national or local law governing legal persons". Em um contexto de governança e redes, a determinação da legitimidade de uma atividade dentro de um sistema não é definitiva e, geralmente, pode ser questionada por referência a outro sistema ${ }^{176}$.

A proliferação dessas redes regulatórias não é pacífica e tem sido sujeita a críticas de que pode implicar redução de transparência e impedir a responsabilidade

\footnotetext{
173 Cf. disponível [on-line] in http://www.efta.int/content/advisory-bodies/resolutions-andopinions/CCRes/26Jun2002-ResoulutionOnCSR-C20R011.doc [15.12.2009]. M. DELMAS-MARTY, Les forces imaginantes $d u$ droit..., pp. 324-5, distingue a governança global distinto da governança empresarial, que se limita ao campo privado das sociedades, e a "boa governança" que leva à adoção de boas práticas em negócios públicos. Vide para um detalhamento maior sobre o tema S. PICCIOTTO, Regulatory Networks and Global Governance, cf. disponível [on-line] in http://eprints.lancs.ac.uk/232/1/reg_networks_\&_glob_gov.pdf [3.1.2010]; F. SNYDER, Economic Globalisation and the Law in the $21^{\text {st }}$ Century, cf. disponível [on-line] in http://www.francissnyder.com/tl_files/contents/articles/Economic_Globalisation_and_the_Law_in_the_21st_Century_fin.pd $f[3.1 .2010]$ e M. R. FERRARESE, Diritto sconfinato..., pp. 28 e ss.

${ }^{174}$ F. CASUCCI, Il diritto 'plurale'..., pp. 65-6.

175 M. DELMAS-MARTY, Les forces imaginantes du droit..., pp. 325-6.

${ }^{176}$ S. PICCIOTTO, Regulatory Networks....
} 
política ${ }^{177}$. Além disso, ressalta PICCIOTTO, "the fragmentation of the public sphere sometimes involves the creation of largely private arenas to which only the more privileged or powerful economic actors have access, resulting in a kind of privatization of justice" 178 .

Para CASUCCI, além de solucionar essas questões, a governança, para que seja eficiente, deve ser baseada em objetivos concretos, como a redução entre a economia financeira e a economia real, a sustentabilidade das atividades econômicas, e etc. ${ }^{179}$.

Não é o escopo deste trabalho aprofundar o debate sobre governança global, respectivos limites e contribuições. De qualquer modo, o tema reflete como a globalização afeta a concepção do direito na sociedade pós-industrial e reforça a necessidade de o direito assumir funções comunicativas.

\subsection{Pluralismo jurídico}

O pluralismo jurídico ${ }^{180}$ tem origem nas teorias antiformalistas européias do século XIX, início do século XX, como reação à concepção monista do direito, como formulada pelo juspositivismo ${ }^{181}$.

O monismo ${ }^{182}$ é uma noção ocidental (não leva em consideração a China, por exemplo), ligada à sociedade daqueles mesmos séculos ${ }^{183}$.

\footnotetext{
${ }^{177}$ P. S. BERMAN, From international law..., pp. 502-3.

178 S. PICCIOTTO, Regulatory Networks....

${ }^{179}$ F. CASUCCI, Il diritto 'plurale'..., pp. 72-3.

180 C. FARALli, Vicende del pluralismo giuridico..., p. 93, distingue pluralidade de ordenamentos jurídicos e pluralismo jurídico. A primeira seria uma situação de fato descrita, ao passo que o segundo, sentido adotado neste trabalho, refere-se ao modelo teórico explicativo baseado na pluralidade de ordenamentos jurídicos. J. GILISSEN, Introduction a l'etude comparee du pluralisme juridique, in J. GILISSEN (org.), Le pluralisme juridique, Bruxelles, Université de Bruxelles, 1971, p. 9, observa que já no direito antigo e no direito da baixa Idade Média é possível constatar a pluralidade de ordenamentos jurídicos. Segundo GILISSEN, mesmo no direito romano, aparentemente monista, havia pluralismo.

181 C. FARALLI, Vicende del pluralismo giuridico..., pp. 99 e ss., que cita, entre outros, Kantorowicz, Gierke, Gurvitch, Santi Romano. A autora adverte que já havia traços da teoria pluralista em teorias juspositivistas (Thon e Bierling). Assim, não há vínculo teórico unívoco e direto entre normativismo e monismo, nem entre institucionalismo e pluralismo. Além deles, Ehrlich, que cunhou a expressão direito vivente, teve importante contribuição o desenvolvimento teórico do pluralismo. Vide D. TERRE, Le pluralisme et le droit, in Archives de philosophie du droit, n. 49, 2006, pp. 76-7.

182 Segundo D. BODIN, Le pluralisme juridique en droit international privé, in Archives de philosophie du droit, n. 49, 2006, pp. 275-8, a teoria do pluralismo jurídico se concebe por oposição ao monismo e também ao dualismo, mas neste caso, sob a perspectiva da auto-executoriedade das normas de direito internacional do ponto de vista do ordenamento jurídico estatal.

183 J. GILISSEN, Introduction a l'etude comparee..., p. 8. Segundo GILISSEN, a noção levou a conseqüências absurdas, contrárias à realidade ou evolução do direito. Para ele (p. 7) " si l'on adopte cette conception du droit, il n’y aurai pas de droit dans les sociétés sans Etats, dans le sociétés sans lois étatiques. La majeur partie du moyen âge occidental n'aurait pas connu du règles juridique, parce que la notion d'Etat souverain n'y apparait que tardivement et que la loi, en tant que règle juridique générale et permanente dictée par l'autorité, y est presque inconnue avant le xiiie siècle. Les sociétés archaïques seraient des sociétés sans droit. La coutume ne serait pas source du droit".
} 
Principalmente a partir dos anos 70 e 80 do século passado, surge o "novo pluralismo" $" 184$, apoiado nos estudos da antropologia e da sociologia, muito relacionados aos países coloniais, africanos e asiáticos, em que conviviam direitos tradicionais (costumeiros e hindu, respectivamente) e direitos de natureza européia ${ }^{185}$.

O ponto de partida é, como destaca SANTOS "um problema epistemológico: qual a verdade ou validade do conhecimento jus-científico oficial que concebe como nãodireito ou ignorância do direito que 'vale' para vastos sectores das classes populares como outro direito ou conhecimento jurídico alternativo?" ${ }^{186}$. A premissa é, assim, a observação de, como aponta RoUlAND, que "todas as sociedades modernas ou tradicionais, em graus diversos, são sociologicamente plurais, no sentido de se comporem de grupos secundários, com maior ou menor autonomia" e de que "existem grupos aquém e além do Estado. Eles produzem seu próprio direito, que confirma, infirma ou se afasta do direito estatal" ${ }^{187}$.

De acordo com VANDERLINDEN, o pluralismo se desenvolve por razões específicas, tais como a necessidade de afirmar a superiodade de um grupo dominante (ex. Igreja), garantir equiíbrio entre grupos sociais, realizar a especificidade das instituições, a independência das instituições, ou a descentralização jurídica ${ }^{188}$.

Segundo RoulAND, há uma versão fraca e outra forte do pluralismo: a primeira, "alude à existência, no seio de determinada sociedade, de mecanismos jurídicos diferentes que se aplicam a situações idênticas", que reverte em vantagem para o direito estatal; a segunda "inspira-se na idéia de que os diferentes grupos sociais vêem cruzar-

\footnotetext{
${ }^{184}$ C. FARALLI, Vicende del pluralismo giuridico..., pp. 95-7. A autora contrapõe esse pluralismo (de que são expoentes Pospísil e Moore) ao pluralismo clássico, do século XIX e primeira metdade do século XX. N. BobBIO, Teoria dell'ordinamento giuridico, trad. port. de Maria Celeste Cordeiro Leite dos Santos, $10^{\text {a }}$ ed., Brasília, Universidade de Brasília, 1999, p. 163, denomina este pluralismo de "pluralismo institucional", porque "a sua tese principal é a de que existe um ordenamento jurídico onde exista uma instituição, ou seja, um grupo social organizado".

185 J. GILISSEN, Introduction a l'etude comparee..., p. 10. Vide, por exemplo, nesse volume organizado por J. GiLISSEN (Le pluralisme juridique) os ensaios a respeito do pluralismo como resultado do colonialismo na África do Sul, na Etiópia, Mali. Ali, há também ensaio sobre a China e sobre a União Soviética.

${ }^{186}$ B. de S. SAnTos (org.), Conhecimento Prudente para uma Vida Decente - Um Discurso sobre as Ciências Revisitado, São Paulo, Cortez, 2004, p. 46.

${ }^{187}$ N. Rouland, Aux confins ..., p. 173

${ }^{188}$ J. VANDERLINDEN, Le pluralisme juridique - essai de synthèse, in J. GILISSEN (org.), Le pluralisme juridique, Bruxelles, Université de Bruxelles, 1971, p. 27. VANDERLINDEN (p. 31) anota que o exemplo clássico de pluralismo em razão da especificidade das instituições é o direito comercial ou droit marchand (e lex mercatoria, então), por duas razões "celui de dépasser les limites étroites du droit propre à une group social ou politique déterminé (entre l'organisation des premier marchés où venaient s'approvisionner les habitant de villages différent et le commerce international contemporain, il n'y a, tout compte fait, qu'une differénce d'echelle) et celui de disposer de mécanisme informels permettant aux transactions commerciales de se dérouler efficacement sans être alourdies par un formalisme trop rigoroureux....".
} 
se em seu seio múltiplas ordens jurídicas: o direito estatal, mas também aquele produzido por outros grupos, que podem coincidir ou divergir" ${ }^{\prime 189}$.

A noção de pluralismo fraco corresponde ao pluralismo jurídico no sentido, dado por BoDIN, de pluralismo legislativo ${ }^{190}$. A análise será restrita à versão forte de pluralismo jurídico ${ }^{191}$.

Embora, também de acordo com BoDIN, antropólogos e sociólogos divergem em relação à qualificação de direito de algumas de suas manifestações, pluralismo jurídico é entendido por eles como uma pluralidade de ordens jurídicas em vigor no contexto de uma mesma socidade estabelecida sobre um mesmo território, sendo, porém, alguns indivíduos submetidos a determinadas regras e outros a outras regras ${ }^{192}$.

O pluralismo jurídico é, segundo SANTOS, o conceito chave de uma visão pósmoderna do direito ${ }^{193}$. Ocorre que, na sociedade pós-industrial, informada pela globalização - entendida também como redefinição dos limites espaço-temporais ${ }^{194}$-, em que se formam também comunidades de interesse e não somente de lugar ${ }^{195}$, o conceito de pluralismo não pode estar necessariamente vinculado à noção de território ou de espaço geográfico ou político.

\footnotetext{
${ }^{189}$ N. Rouland, Aux confins ..., p. 158.

190 D. BodIn, Le pluralisme juridique..., pp. 276-8. Ou seja, o pluralismo jurídico seria reduzido à caracterização da "législation d'un État en tant qu'elle offre aux personnes qui sont soumises à ses dispostions le choix entre plusieurs régimes ayant chacun leurs propres conditions et leur propres effets". O autor (pp. 276-7) menciona ainda outras acepções da expressão: aquela da antropologia, segundo a qual o pluralismo seria a descrição do estado de uma sociedade de indivíduos que vivem em um mesmo território, mas não estão sujeitos à mesma regra. Uma outra corrente, fundada na moral política, vê ao lado das fontes formais e tradicionais do Estado, regras emanadas de outras organizações também com legitimidade ("pode falar-se de pluralismo ainda num outro sentido - o de que a ordem tem várias fontes de manifestação, não podendo ser reduzida ao direito formal", salienta A. M. HESPANHA, Cultura Jurídica..., p. 116). Outro sentido da expressão pluralismo jurídico é aquele relacionado ao caráter de um direito supranacional em que os Estados têm um certo espaço para implementar suas obrigações (o que seria equivalente à harmonização por diretivas na Europa, por exemplo). Um último sentido, adotado por BoDIN, é baseado na teoria institucionalista de Santi Romano, de que existem diversas ordens jurídicas, não redutíveis umas às outras (especialmente aos Estados), com diversas relações entre essas ordens. J. VANDERLINDEN, Le pluralisme juridique..., p. 20, aponta que pluralismo implica a existência de diversos mecanismos jurídicos, mas não necessariamente sistemas jurídicos. Por isso, para ele (p. 38), o objeto do pluralismo é todo o direito de uma determinada sociedade, um ramo desse direito ou mesmo uma parte mais ou menos importante desses ramos.

191 C. FARALLI, Vicende del pluralismo giuridico..., p. 93, distingue pluralidade de ordenamentos jurídicos de pluralismo jurídico. A primeira seria uma situação de fato descrita, ao passo que o segundo, sentido adotado neste trabalho, refere-se ao modelo teórico explicativo baseado na pluralidade de ordenamentos jurídicos.

${ }^{192}$ D. BodIn, Le pluralisme juridique..., p. 276.

193 B. DE S. SANTOS, law - A Map of Misreading ..., p. 297.

${ }^{194}$ M. R. FERRARESE, Le istituzioni della globalizzazione..., pp. 42-5. Vide também V. OlGIATI, Lex mercatoria e communitas..., pp. 357 e ss.

${ }^{195}$ P. S. BERMAN, From international law..., pp. 515-17. BERMAN afirma que "community formation is a psychological process not a naturally occurring phenomenon based on external realities".
} 
Por isso, o sentido atribuído pela antropologia e pela sociologia deve ser substituído por um novo, baseado "na concepção de diferentes espaços jurídicos sobrepostos, interpenetrados e misturados", fazendo com que a vida jurídica seja “constituída de uma intersecção de ordens jurídicas diferentes - isto é, por interlegalidade" 196 .

Segundo BoBBIO, o pluralismo jurídico leva à distinção de ordenamentos acima do Estado, como o internacional; abaixo do Estado, "como os ordenamentos propriamente sociais, que o Estado reconhece, limitando-os ou absorvendo-os"; ao lado do Estado, como o da Igreja; e os ordenamentos contra o Estado, como as seitas secretas $^{197}$.

Para Teubner, o pluralismo, que já passou do discurso sobre as sociedades coloniais para as comunidades étnicas, culturais e religiosas nos Estados modernos, precisa voltar-se não mais aos grupos, mas nos discursos. Realçando assim a função comunicativa do direito, "legal pluralism is then defined no longer as a set of conflicting social norms but as a multiplicity of diverse communicative processes in a given social field that observe social action under the binary code of legal/illegal"198.

A concepção de um pluralismo jurídico fundado em espaços jurídicos, que realiza processos comunicativos, é fundamental para a compreensão de fenômenos jurídicos, especialmente os transnacionais como a nova lex mercatoria.

\footnotetext{
${ }^{196}$ B. DE S. SANTOS, law - A Map of Misreading..., p. 298. O sociólogo português anteriormente, em Notas sobre a História Jurídico-Social de Pasárgada, p. 110, in C. SouTO e J. FALCão (org.), Sociologia Jurídica - leituras básicas de sociologia jurídica, São Paulo, Pioneira, 1980, definiu que pluralismo jurídico consiste na vigência, oficial ou não, em um mesmo espaço geopolítico de mais de uma ordem jurídica, seja por fundamentação, e.g., econômica, rácica, profissional, em uma transformação revolucionária. A respeito da interlegalidade, BOAVENTURA DE SOUSA SANTOS, afirmou, uma vez que os espaços jurídicos distintos não são sincrônicos, o modo pelo qual a interlegalidade é realizada consiste em um processo dinâmico. V. OlgiATI, Lex mercatoria e communitas..., pp. 363-4, aponta para uma "trasformazione che il fenomeno della interlegalità produce nella percezione sociale dell'intera esperienza giuridica, e cioè la emergenza di aspettative sociali normativamente strutturate secondo 'un senso comune giuridico' non più condizionato dalle tradizionali dicotomie del pensiero giuridico positivisto (como direito público e privado)... Il fenomeno della 'interlegalità' disegna quindi un particolare modo di essere dello stesso pluralismo giuridico contemporaneo: un modo che appare ad un tempo decostruttivo e ricostruttivo del tessuto socio-normativo dell'intero sistema sociale".

${ }^{197}$ N. BOBBIO, Teoria dell'ordinamento giuridico..., p. 164. J. VANDERLINDEN, Le pluralisme juridique..., pp. 44 e ss., afirma existirem as seguintes modalidades de pluralismo: paralelo ou integrado, conforme exista ou não pontos de contato entre os mecanismos diferentes a se aplicarem nas situações idênticas (e aqui parece se tratar mais de pluralismo legislativo); cumulativo (simultâneo) ou isolado, isto é, sem possibilidade de intervenção de outro; pluralismo optativo ou obrigatório; controlado ou independente, em relação à ordem jurídica principal (quando houver), como no colonialismo; remedidador ou preventivo, ou seja, para corrigir situação em que determina solução existente não é satisfatória ou prevenir que tal aconteça; antagonista ou complementar, imposto ou convencionado.

${ }^{198}$ G. TEUBNER, 'Global Burkowina' '.., p. 14.
} 


\subsection{Informalidade: espontaneidade e oralidade do direito}

\subsubsection{Espontaneidade}

Na sociedade pós-industrial, com a organização mais horizontal da sociedade, com a reorganização das fontes do direito e a compreensão da autoridade como construção social, são retomados os sentimentos jurídicos espontâneos ${ }^{199}$.

Para TEUBNER, direito genuinamente espontâneo é aquele formado "na base de coordenação informal de comportamento num processo gradativo de interações recursivas, mas em razão de serem positivados em processos decisórios organizados nos subsistemas sociais"200.

TEUBnER afirma que os processos de formação do direito na sociedade pósindustrial estão condicionados não só por impulsos informais de criação do direito, mas também por impulsos organizados, isto é, assinala, "estamos diante de uma mescla de processos espontâneos e organizados", de forma a existir "a criação normativa espontânea no centro do direito...” e também, como “...conseqüência da racionalização nos setores parciais da sociedade em escala mundial” "...a criação normativa organizada nos setores parciais da sociedade na periferia do direito" 201 .

De fato, a formação dos instrumentos de soft law, de que a nova lex mercatoria se nutre em larga escala, são resultado do trabalho "organizado", como os contratostipo, os INCOTERMS e outros instrumentos da Cãmara de Comércio Internacional ou os Princípios UNIDROIT.

Já GALGANO, ao traçar um paralelo entre a nova lex mercatoria e o antigo ius mercatorum, atribui a ambos a caractrística de "direito espontâneo", uma vez que são criados pelo próprio grupo social, sem mediação do poder político ou legislativo - no caso da nova lex mercatoria, sem mediação do Estado ${ }^{202}$.

Nesta perspectiva - que ora se adota - o termo espontâneo tem um significado mais amplo, definido em contraste com a concepção monista de formação do direito apenas por meios oficiais.

\footnotetext{
199 A. M. Hespanha, Cultura Jurídica Européia - Síntese de um Milênio, Florianópolis, Fundação Boiteux, 2005, p. 472.

${ }^{200}$ G. TEubner, Direito, Sistema e Policontexturalidade..., p. 112.

${ }^{201}$ G. Teubner, Direito, Sistema e Policontexturalidade..., pp. 112-4.

${ }^{202}$ F. GALGANO, La globalizzazione ..., pp. 56 e ss.
} 


\subsubsection{Oralidade}

O direito da sociedade pós-industrial não é um produto acabado, mas um processo, um constante work in progress, que se desenvolve no centro e na periferia e responde a uma dialética formal/informal (espontâneo). O direito não pode, assim, ser identificado com a norma escrita e com um momento normativo ${ }^{203}$.

Produto de uma construção social, o direito consiste em instrumento de comunicação de que a pluralidade de atores e autoridades dispõe para construção de um diálogo jurídico. Salienta FERRARESE que "mentre il diritto di impronta positivista era chiamato a svolgere la funzione di un linguaggio scritto, con una propria e esclusiva grammatica, oggi il diritto globalizzato si avicina più a svolgere il ruolo di una lingua parlata in ambito internazionale: una sorta di passepertout linguistico ${ }^{204}$, che permette a communicare a persone di diverse nazionalità, ma che ognuno parla a modo proprio, con le proprie inflessioni e costruzioni lessicale"205.

Isto é, ao mesmo tempo em que se constrói uma lingüagem jurídica transnacional que guia as relações intersubjetivas, se formam - como reflexo da glocalização - também dialetos jurídicos locais, com importante influência dos profissionais jurídicos, tais como juízes, árbitros e especialmente os escritórios de advocacia de estilo americano (law firms) ${ }^{206}$.

Segundo FERRARESE, formam-se, desse modo, redes informais de comunicação que servem para inserir em contextos específicos e compensar a abstração de medidas jurídicas $^{207}$.

$\mathrm{O}$ direito atual requer também meios mais ágeis, dinâmicos, responsive e que contribuam para a redução dos custos de transação/informação, superação das barreiras

\footnotetext{
${ }^{203}$ M. R. FERRARESE, Le istituzioni della globalizzazione..., pp. 141 e ss.

204 Não por acaso, M. J. Bonell, Un "codice" internazionale del diritto dei contratti - I Principi UNIDROIT dei contratti commerciali internazionali, $2^{\mathrm{a}}$ ed. Milano, Giuffrè, 2006, p. 24, destaca que os Princípios UNIDROIT para os Contratos Comerciais Internacionais criam "una lingua franca giuridica che può essere utilizzata e compresa in tutto il mondo".

${ }^{205}$ M. R. FERRARESE, Le istituzioni della globalizzazione..., p. 70.

${ }^{206}$ Vide A reestruturação global e o direito - a internacionalização dos campos jurídicos”, in J. E. C. FARIA (org.), Direito e globalização econômica, São Paulo, Malheiros, 1998, pp. 39 e ss. e também item 3.3.6.

${ }^{207}$ M. R. FERRARESE, Le istituzioni della globalizzazione..., p. 73.

FERRARESE, Il diritto al presente, p. 168, enfatiza que "grazie alla propria oralità, il linguaggio dei diritti funziona come un contenitore che tiene in collegamento costante produzioni sociali, culturali ed etniche, con possibili abiti ed esiti giuridici”.
} 
e diferenças linguiísticas e culturais, a que a oralidade pode contribuir mais que a escritura $^{208}$.

A oralidade do direito deve ser entendida, também segundo FERRARESE, "non solo come uso della parola non scritta, ma anche come dimensione che sta al di là della norma e che serve a integrarla", uma vez que o direito escrito "non è autosufficiente e non può funzionare senza il rimando dalla parola scritta a... un contesto di oralità, come avviene... nella negoziazione, o una fattualità che la integra, o il riferimento a standard di carattere sociale, etico o politico, ${ }^{, 209}$.

FERRARESE adverte, entretanto, que os modelos de "oralidade" ou "escritura" do direito são na verdade tipos ideais e que não de forma pura existem na realidade ${ }^{210}$. Ou seja, destacar o papel da oralidade no direito da sociedade pós-industrial não implica que se possa prescindir do direito escrito e que o sentido da mudança é unidirecional. Por exemplo, o direito nos países de common law se torna cada vez mais escrito e o direito de tradição romano-germânica se torna mais oral. Os usos no comércio internacional também ilustram o fenômeno. Embora tradicionalmente orais, convivem, como fonte da nova lex mercatoria, usos não-escritos e escritos - distinção esta que SCHMITTHOFF rotula de usos não-formulados e formulados ${ }^{211}$.

Trata-se, apenas, de realçar a primeiro plano um aspecto do direito que foi secundarizado dos últimos dois ou três séculos. A oralidade e escritura convivem e são complementares, dando origem a - sugere FERRARESE - um direito "escrito-oral"212.

\subsection{O contrato na sociedade pós-industrial}

O contrato, como expressão da autonomia da vontade e, em geral, manifestação informal (espontânea) do direito na sociedade pós-industrial, também assume novos contornos em relação ao direito moderno, refletindo o reconhecimento das autoridades privadas e os rumos da dicotomia entre direiot privado e público.

Na modernidade, salienta SUPIOT, - com base na transição do Japão à modernidade - "ter acesso à cultura do contrato tornou-se a condição de acesso à modernidade e à união das nações", constatando-se que, embora estritamente ocidental,

\footnotetext{
${ }^{208}$ M. R. FERRARESE, Le istituzioni della globalizzazione..., pp. 188 e ss. A autora (p. 190) ressalta que o oral, em razão de gestos, entonação e etc., são mais fáceis de compreender do que o escrito.

${ }^{209}$ M. R. FERRARESE, Le istituzioni della globalizzazione..., p. 161.

${ }^{210}$ M. R. FerRARESE, Le istituzioni della globalizzazione..., p. 161.

${ }^{211}$ C. SCHMITTHOFF, International Business law..., pp 34-5. Vide item 3.5.2.

${ }^{212}$ M. R. FerRARESE, Le istituzioni della globalizzazione ..., p. 162 e ss.
} 
"essa crença na missão civilizadora do contrato é um dos mais potentes motores do Direito contemporâneo" 213 .

Na sociedade pós-industrial, o direito torna-se um produto negociável - no sentido de que é resultado de consenso entre as partes interessadas - e também atua como importante instrumento de comunicação. E o contrato exerce um papel fundamental, central.

GALGANO alerta que "la transizione alla società post-industriale si sviluppa nel segno della continuità, non della frattura, delle forme giuridiche... il quadro del diritto codificato resta imutato. Ma esta imutato perché sono altri, non già leggi, gli strumenti medianti i qualli si attuano le transformazione giuridiche". Portanto, "se continuassimo a concepire il contratto come mera applicazione del diritto, e non come fonte di diritto nuovo, ci precluderemmo la possibilità di comprendere in qual modo muta il diritto del nostro tempo",214.

Esclarece GALGANO que, se outrora os contratos serviam apenas para fazer circular as coisas, atualmente as fazem, criam os produtos financeiros. Assim, conclui GALGANO, "nell'economina della finanza la tecnologia industriale è sostituita dalla tecnica contrattuale" 215 .

Dessa forma, aos moldes schumpeterianos, a inovação jurídica é instrumento da concorrência, e, assim sendo, requer, de um lado, criatividade dos operadores e, de outro, ferramentas capazes de se adequar às novas exigências, lembra FERRARESE ${ }^{216}$. A socióloga do direito italiana afirma que "a questa crisi della legislazione, nella società globalizzata, corrisponde anzitutto un trionfo del diritto contrattuale, diritto flessibile per eccellenza, capace di adattarsi alle più diverse esigenze e di seguire i nuovi percorsi e bisogni della società di mercato, ma capace ancora di dedizione al futuro"217.

No contexto atual, a compreensão do contrato muda, com um maior peso do aspecto cultural das regras. A cultura do contrato, própria dos contraentes, se destaca,

\footnotetext{
${ }^{213}$ A. SUPIOT, Homo Juridicus - Essai sur la function anthropologique du droit, trad. port. de Maria Ermantina de Almeida Prado Galvão, Homo Juridicus - ensaio sobre a função antropológica do direito, São Paulo, Martins Fontes, 2007, p. XXV, p. 99. SUPIOT relata (pp. 102-3) que, "vinda dos bárbaros do Oeste, a cultura do contrato serve para os japoneses comerciarem com os bárbaros do Oeste, mas influenciou muito pouco suas relações internas. Basta uma estatística para desvelar a vitalidade do giri, da arte do compromisso e da evitação das vias do Direito; enquanto os Estados Unidos possuem um advogado para trezentos habitantes, o Japão tem um para dez mil. Grande parte dos sucessos econômicos do Japão (e talvez amanhã da China) explica-se por essa alquimia que liga duas culturas: a da lei e do contrato, importada do Ocidente; e a da harmonia e do vínculo, herdada do confucionismo".

${ }^{214}$ F. GALGANO, Lex mercatoria..., pp. 232-3.

${ }^{215}$ F. Galgano, Lex mercatoria..., p. 18.

${ }^{216}$ M. R. FERRARESE, Le istituzioni della globalizzazione..., p. 19.

${ }^{217}$ M. R. FERRARESE, Il diritto al presente..., p. 137.
} 
colocando de um lado regras culturais e, de outro, as jurídicas, contrapondo a cooperação ao conflito ${ }^{218}$.

Assim como em outros ramos do direito, autoridades tecnocratas ocupam lugares antes ocupados por autoridades políticas, com a autodisciplina contratual no lugar de fontes normativas ${ }^{219}$. A periferia, dessa forma, exerce papel relevante na formação do direito - o que, por outro lado, dá causa a importantes questionamentos no que diz respeito à legitimidade democrática desse direito.

Além disso, o contrato, como fonte normativa ${ }^{220}$, reflete os rumos da distinção entre direito e direito público, cada vez menos nítida na medida em que essas categorias se aproximam uma da outra.

Assim, o contrato passa a tocar interesses que transcendem suas partes e envolvem a esfera dos interesses coletivos (ou privados de relevância pública). Como ensina SUPIOT, "em vez de servir para trocar quantidades, o contrato se 'publiciza' ao participar da definição de bem comum. Isso repercute na autonomia da vontade das partes: elas permanecem livres para querer, mas com a condição de perseguir objetivos que vão além de seu interesse próprio. Sua liberdade é enfeudada na realização desses objetivos. É no campo sócio-econômico que esse fenômeno se manifesta com mais clareza: no plano individual, mediante a normatização dos comportamentos e, no plano coletivo, mediante a instrumentalização das fontes do Direito"221.

Consequentemente, aponta TEUBNER, “o contrato será considerado, de antemão, como constituído de duas dinâmicas sociais equivalentes, e a missão do direito não será uma correção marginal ocasional, e sim uma conciliação corrente de colisões discursivas" ${ }^{222}$.

É esta a "missão civilizadora" do contrato na sociedade pós-industrial. Circula conhecimento, informações, cria produtos, aloca riscos, constrói diálogos e consensos e exerce função normativa, refletindo a síntese do acoplamento dos processos sociais e econômicos na formação do direito.

\footnotetext{
${ }^{218}$ M. R. FERRARESE, Le istituzioni della globalizzazione..., p. 66-7.

${ }^{219}$ F. GALGANO, La globalizzazione..., 2005, p. 10.

${ }^{220}$ Vide itens 3.5.2 e 4.1.2.1.

${ }^{221}$ A. SUPIOT, Homo Juridicus..., p. 208.

${ }^{222}$ G. TEUBner, Direito, Sistema e Policontexturalidade..., p. 261. Para TEUBNER, Breaking Frames ..., p. 23, o paradoxo é que o direito - a que ele denomina de global - implica expansão da produção normativa privada que reconhece o quanto “i governi 'privati' siano in realtà 'pubblici', a partir de "elementi consensuali fondamentali del contratto".
} 


\subsection{Direito na sociedade pós-industrial: síntese}

As características do direito na sociedade pós-industrial destacadas acima têm um denominador comum: o direito como expressão social ${ }^{223}$.

HESPANHA recorda que o direito "pertence ao ser de uma sociedade, condição ineliminável para que aquela sociedade viva e continue a viver como sociedade, não se manifestando em um amontoado de homens em perene rixa entre si”,224.

O direito da sociedade pós-industrial pretende ir além da noção territorializada ${ }^{225}$ e oficial do direito fruto da ideologia iluminista e juspositivista. A paisagem é aquela do pluralismo jurídico, mas não só - no sentido tradicional - da coexistência de várias ordens jurídicas nnecessariamente no mesmo espaço geográfico ou político, mas também na existência, em um espaço imaterial, jurídico, de uma pluralidade de ordens jurídicas, mais ou menos completas, que estabelecem entre si relações em vários níveis e de natureza variada: independência, autonomia, complementaridade integração e também de concorrência ${ }^{226}$.

A autoridade - no sentido de criar e aplicar as regras jurídicas - não repousa apenas no Estado, o que não significa, contudo, que ele deixe de existir, deixe de produzir e aplicar regras, ser também fonte de legitimidade e exercer papel fundamental no contexto atual. Mas significa que co-existem outras autoridades, algumas supranacionais, fruto do direito internacional, outras ao lado dos Estados, cuja condição é baseada no reconhecimento como tal pelo próprio grupo social.

A distinção entre a função privada e pública esmaece e com ela a noção de direito privado e público. O direito privado se publiciza e o direito público se privatiza $^{227}$. Assim também o contrato, que transcende a esfera puramente bipartite, evocando a cooperação juntamente com a troca, recriando um diálogo simultâneo com a justiça distributiva e com a justiça comutativa.

Na sociedade pós-industrial, a dialética centro/periferia - esta última, além de fonte normativa, é também fonte cognitiva na medida em que se situa na fronteira com

\footnotetext{
${ }^{223}$ P. GROSSI, L'Europa del Diritto, Roma-Bari, Laterza, 2007, p. 223: “il diritto esprime prima la società che lo Stato".

${ }^{224}$ A. M. HESPANHA, Cultura Jurídica Européia, p. 57.

${ }^{225}$ Por isso, M. R. FerRarese, Diritto sconfinato..., adjetiva o direito na sociedade pós-industrial de como sconfinato, isto é, que ultrapassa fronteiras.

${ }^{226}$ D. TERRE, Le pluralisme et le droit..., p. 77.

${ }^{227}$ M. DELMAS-MARTY, Les forces imaginantes du droit..., p. 324.
} 
os processos sociais e econômicos ${ }^{228}$-, revela instâncias formais e informais (espontâneas) da produção do direito.

O direito da sociedade pós-industrial é processo (e não procedimento), openended, work in progress $^{229}$, e em certa medida horizontal, plural, factual, informal, em rede, escrito-oral e também negociável. Nesse contexto, o papel criador e inventivo dos juízes ganha relevância ${ }^{230}$, e os dogmas da segurança e certeza jurídicas são revisitados $^{231}$. O grande desafio desse direito é superar o déficit democrático, isto é, construir uma ordem jurídica que não penda para forças econômicas, políticas ou sociais, mas que proporcione harmonia, equilíbrio entre esses processos.

A intersecção de ordens jurídicas diferentes - interlegalidade ${ }^{232}-$, somada a tais características do direito, faz com que, na sociedade pós-industrial, o direito esteja em Hermes, o mediador universal, o grande comunicador. Repousa na necessidade e na função de circulação das informações, dos diálogos, dos processos de formação de consenso, das trocas, de ultrapassar as passagens desconhecidas. Assim como Hermes

\footnotetext{
${ }^{228}$ N. BoBBio, Da estrutura à função..., p. 94, enfatiza que deve ser superada a análise do direito como meio de conservação (tradicional, também em razão ao caráter geral e abstrato de suas regras, derrocado pela complexidade das situações concretas), sublinhando que "a função do direito não é apenas manter a ordem constituída, mas também mudá-la, adaptando-a às mudanças sociais".

${ }^{229}$ A. SuPIOT, Homo Juridicus..., p. 46, alerta que "uma ordem jurídica só cumpre sua função antropológica se garante a todo recém-chegado à Terra, de um lado, a preexistência de um mundo já presente, que o assegure no longo termo de sua identidade, e, do outro, a possibilidade de transformar esse mundo e de lhe imprimir marca própria".

${ }^{230}$ Como se demonstará com o papel dos árbitros no contexto da nova lex mercatoria.

${ }^{231}$ M. R. Ferrarese, Le istituzioni della globalizzazione..., pp. 27 e ss., 49 e ss. e pp. 173 e ss., sublinha que as características do direito da sociedade pós-industrial afetam mais as estruturas do direito de tradição romano-germânica do que as estruturas da common law. Naquele direito, o direito tinha um caráter predominantemente público (i.e., direito como comando/obediência), até porque historicamente a Europa, diante da ruptura medieval, precisou construir uma ordem política, estabelecendo uma comunicação vertical. Além de não ter sofrido tal ruptura, na common law, a influência do direito privado, de conotação mais econômica do que política, era historicamente predominante. Além disso, na common law o sentido de produção do direito não é unidirecional. Ao lado do direito de formação política, a jurisprudência também forma o direito, mas de baixo e a partir de contextos específico, caracterizando um work in progress (por isso, o rótulo também de judge-made law). A common law dá origem a um direito mais pragmático, instrumental, teleológico, moldado mais pela razão estratégica que pela razão paramétrica, que combina melhor escritura e oralidade do direito. Além disso, especificamente nos Estados Unidos, sempre esteve presente a idéia de competição por meio do direito entre atores públicos privados, que podem produzir o direito. A cultura jurídica norte-americana, dessa forma, sempre conviveu com a idéia de bargaining pelo direito, do direito como produto negociável. FERRARESE (p. 52) aponta, assim, que "la globalizzazione sembra agredire il mondo giuridico europeo-continentale nei suoi modulli più tipici, a partire dall'idea di un diritto che è monopolio dello stato. Lo stesso non potrebbe dirsi per il diritto nord-americano, che da sempre è esposto all'influenza e all'impulso dei privati e soggettp alle sfide del federalismo: esse dunque presenta caratteri straordinariamente affini al diritto globale, fino al punto da potersi configurare... quale 'metafora' dello stesso". A. C. CuTLER, Private Power..., p. 235, com base em B. de. S. Santos (Toward a New Common Sense - Law, Science, and Politics in the Paradigmatic Transition, 1995) que não haveria globalização da cultura jurídica, mas globalismo localizado da cultura e práticas dos EUA.

${ }^{232}$ B. DE S. SANTOS, law - A Map of Misreading ..., p. 298.
} 
era o responsável por levar as mensagens aos deuses, o direito deve ser essencialmente instrumento de comunicação ${ }^{233}$.

Nesse sentido, o antropólogo do direito ALAIN SUPIOT menciona que "as instituições devem, então, deixar espaço para sistemas maleáveis de comunicação que permitam aos homens reagir uns aos outros e ajustar mutuamente seus comportamentos num conjunto reticular que se regula por si só. O problema então é unir e não mais instituir, comunicar e não mais ordenar, regular e não mais regulamentar.... Em Direito como em outras áreas, a hora é das redes, ou seja, das estruturas policêntricas, das quais cada elemento é, a um só tempo autônomo e ligado a todos os outros"234.

A empreitada do direito da sociedade pós-industrial não requer, como o fez a sociedade moderna, a ruptura das instituições. A mudança coexiste com a continuidade das formas existentes e é realizada principalmente pelo contrato. Este, por sua vez, transcende a função de mera circulação de produtos e assume outras funções (criadora, instrumento de concorrência, comunicativa, normativa, entre outras) além da relação individual.

Identificadas algumas características e a função do direito na sociedade pósindustrial, cabe então voltar-se a uma de suas expressões: a nova lex mercatoria. Primeio, descrevendo seus elementos. Em seguida, refletindo a respeito das críticas a respeito, limites, desafios.

\footnotetext{
${ }^{233}$ M. R. FERRARESE, Le istituzioni della globalizzazione..., p. 62-3.

${ }^{234}$ A. SUPIOT, Homo Juridicus..., pp. 146-7.
} 


\section{SEGUNDA PARTE}

\section{A NOVA LEX MERCATORIA}

\subsection{Noção preliminar}

A expressão nova lex mercatoria nem sempre é utilizada para se referir ao mesmo fenômeno. Isto é, a imprecisão com que o termo é utilizado não é incomum. $\mathrm{Na}$ literatura, como se verá a seguir, o termo nova lex mercatoria às vezes é empregado em uma acepção mais aimpla, i.e., para significar o conjunto de todas as relações econômicas transnacionais ou direito econômico internacional. Outras vezes, nova lex mercatoria assume um significado mais restrito associado a uma parte apenas do comércio internacional. A expressão nova lex mercatoria também é utilizada para designar um direito não nacional. Assim, antes mesmo de investigar os elementos da nova lex mercatoria, cabe indagar o que exatamente quer se designar com tal expressão.

Para GOLDMAN, a nova lex mercatoria seria "a set of general principles and customary rules spontaneously referred to or elaborated in the framework of international trade, without reference to a particular system of law"235.

SCHMITTHOFF, por sua vez, afirma que "the law of international trade emerges today as a body of autonomous legal rules, to a large measure independent of national systems of law, founded on the universally recognized twin principles of freedom of contracting and recognition of commercial arbitration awards, and supplemented by international legislation dealing with specific topics. The new lex mercatoria is formulated in general conditions of sale and standard forms of contract accepted by the international business community and in international conventions and uniform statues incorporated by states into their municipal law"236.

\footnotetext{
235 B. Goldman, The applicable law - general principles of law - the "lex mercatoria", in Contemporary problems in international arbitration, Julian D. M. Lew, Center for Commercial Studies, London, 1986, p. 116. H. M. HUCK, Sentença Estrangeira e Lex Mercatoria-Horizontes e Fronteiras do Comércio Internacional, São Paulo, Saraiva, 1994, p. 116, entre outros, entende que o jurista francês revisitou seus entendimentos sobre o tema, recuando e adotando outra posição quanto a constituir a um ordenamento jurídico.

${ }^{236}$ C. SCHMITTHOFF, International Business Law..., p. 36.
} 
De acordo com VIRALLY, a lex mercatoria "s'agirait d'un troisième droit, crée par des particuliers pour régir des rapports de droit privé ... mais qui se présente comme du droit non national... "237.

STRENGER, por sua vez, define a lex mercatoria como "um conjunto de procedimentos que possibilita adequadas soluções para as expectativas do comércio internacional, sem conexões necessárias com os sistemas de forma juridicamente eficaz"238.

Para FORTIER, a lex mercatoria seria uma espécie de "anational system of general principles, customs and rules spontaneously referred to, elaborated and followed in the framework of international trade and commerce..."239.

MARRELlA, sob outra perspectiva, afirma que "la lex mercatoria altro non è che diritto privato-materiale-astatuale" ${ }^{240}$. No mesmo sentido, para LOQUIN seria “...un droit matériel transnational du commerce international"241.

Já segundo TEUBNER, a nova lex mercatoria seria o direito transnacional das transações econômicas ${ }^{242}$.

GALGANO sustenta que "per nuova lex mercatoria oggi si intende un diritto creato dal ceto imprenditoriale, senza la mediazione del potere legislativo degli Stati, e formato da regole destinate a disciplinare in modo uniforme, al di là delle unità politiche degli Stati, i rapporti commerciali che se instaurano entro l'unità economica dei mercati" ${ }^{243}$. No mesmo sentido, FERRARESE afirma que a nova lex mercatoria é relacionada a um conjunto de medidas jurídicas comerciais produzidas de modo privado pelo mundo empresarial, medidas estas dotadas de especialidade e universalidade. Trata-se, segundo a autora, de um direito cosmopolita que consistitira em uma forma de comunicação universal que supera barreiras estatais ${ }^{244}$.

De acordo com FRIGNANI, a nova lex mercatoria seria um direito de formação espontânea, a partir de um corpo de regras e institutos concernentes ao comércio

\footnotetext{
${ }^{237}$ M. VIRALLY, Un tiers droit?..., p. 374.

${ }^{238}$ I. STRENGER, Direito do Comércio Internacional e Lex Mercatoria, São Paulo, LTr, 1996, p. 78.

${ }^{239}$ L. Y. FORTIER, New trends in governing law - the new, new lex mercatoria, or, back to the future, in ICSID Review - Foreign Investment Law Journal, v. 16, n. 1, 2001, p. 11.

${ }^{240}$ F. MARrella, La nuova lex mercatoria, Principi Unidroit ed usi dei contratti del commercio internazionale - v. XXX - Trattato di diritto commerciale e di diritto pubblico dell'economia diretto da Francesco Galgano, Padova, Cedam, 2003, p. 39.

${ }^{241}$ E. LOQUIN, Où en est la lex mercatoria..., p. 24.

${ }^{242}$ G. TEUBNER, Breaking Frames..., p. 22.

${ }^{243}$ F. GALGANO, Lex mercatoria..., p. 238.

${ }^{244}$ M. F. FERRARESE, Le istituzioni della..., pp. 90-91.
} 
internacional comumente aplicado pelos mercadores, cientes de que se trata de regras jurídicas ou que, pelo menos, a contraparte se comportará de acordo com essas regras ${ }^{245}$.

CUTLER, por sua vez, afirma que "law merchant is a form of transnationalized law embodying both the globalization of local law, as Anglo-American corporate laws are adopted throughout the world, and the localization of global law, as states are subjected to increasing discipline from legal regimes developed by international, transnational, and global organizations" ... "In some cases, merchant laws operate dialectically creating deterritorialized transactions and agreements, but then reterritorializing them to facilitate enforcement" ${ }^{, 246}$.

Ponderadas as definições acima, adota-se por ora, como noção mínima e preliminar $^{247}$, da nova lex mercatoria a seguinte: (i) direito material; (ii) transnacional, isto é, não produzido em nível nacional ou internacional por nenhum Estado específico; (iii) comportando, de outro lado, uma dimensão local transnacionalizada; cujas regras são (iv) criadas de forma espontânea, em maior ou menor escala, pela própria classe mercantil; (v) aplicáveis aos contratos comerciais internacionais; e que (vii) tem um aspecto comunicativo importante $\mathrm{e}^{248}$.

\subsection{Notas históricas sobre a lex mercatoria}

Em termos de seu desenvolvimento histórico, é comum, como em SCHMitTHOFF $^{249}$, a identificação de três períodos de desenvolvimento da lex mercatoria $^{250}$. O primeiro período seria o ius mercatorum da Idade Média, o segundo a lex mercatoria a partir do advento do Estado moderno e o terceiro período seria aquele do desenvolvimento da lex mercatoria contemporânea.

\footnotetext{
245 A. FRIGNANI, L'arbitrato commerciale internazionale..., p. 136.

246 A. C. CUTLER, Private Power..., p. 20.

${ }^{247}$ A caracterização da nova lex mercatoria como ordenamento jurídico ou não é objeto do item 4.1.3.4.

${ }^{248}$ Vide, para outras definições de lex mercatoria, J. C. de MAGALHÃES, "Lex Mercatoria" - Evolução e Posição Atual, in Revista dos Tribunais 709/1994, pp. 42-45, e F. MARRELlA, La nuova lex mercatoria.... ${ }^{249}$ C. SCHMITTHOFF, International Business Law... pp. 20-37.

${ }^{250}$ Goldman faz referência ao jus gentium do direito romano, sugerindo uma lex mercatoria anterior à Idade Média, período em que é mais freqüente a referência ao início da lex mercatoria. V. OLGIATI, Lex mercatoria e communitas..., p. 355, identifica quatro modelos ou fases da lex mercatoria, o primeiro deles sendo uma lex mercatoria arcaica, existente mesmo antes do advento das formas de constituição política estatais. Isto é, não havia sustento político e organizacional direto ao sistema ou grupo social. Neste cenário, a força contratual era largamente baseada na relação entre as partes, sendo a confiança e a reciprocidade seus pressupostos normativos. Como resultado, as relações entre as partes eram altamente informadas pela eqüidade. Este período não será objeto deste trabalho.
} 
Entretanto, antes de revisitar brevemente os períodos de desenvolvimento da nova lex mercatoria, vale cuidar, de maneira rápida, do sentido histórico da expressão.

\subsubsection{A expressão lex mercatoria}

O fenômeno da lex mercatoria é cunhado com diversas expressões ao longo da história, tais como ius mercatorum, law merchant, direito mercantil, droit commercial et maritime, direito comercial $^{251}$. É também comum a referência a the law of international trade (ou international trade law) ${ }^{252}$, the law of international commercial transactions $^{253}$, direito corporativo ${ }^{254}$, princípios gerais de direito comercial internacional, entre outros.

FORTUNATI comenta que, durante todo o período medieval e na idade moderna, a expressão lex mercatoria (direito do mercado) é desconhecida na Europa, com exceção da Inglaterra ${ }^{255}$. A expressão ius mercatorum (direito dos mercadores), por sua vez, também não aparece em qualquer texto, sendo comum à época a referência a mercatoria consuetudo ou mercatorius stylus.

GALGANO lembra, entretanto, que as duas expressões eram restritas à lingüagem jurídica douta dos comentadores (como Bártolo de Sassoferrato, 1314-1357, e Baldo de Ulbadis, 1327-1400). As expressões designam mais do que um ramo do direito (as atividades dos mercadores), um modo particular de criá-lo (criação pela própria classe mercantil, sem mediação política) ${ }^{256}$.

Na Europa continental, somente a partir do século XVII, com a obra de Johann Marquard, de 1662, a expressão passa a ser utilizada com o sentido de um sistema jurídico específico cujo objeto era disciplinar um setor econômico particular.

$\mathrm{Na}$ Inglaterra, a lex mercatoria tem início no século XIII, mas o sentido da expressão não é unívoco ao longo da história. Com efeito, FORTUNATI alerta que "in

\footnotetext{
${ }^{251}$ M. FORTUNATI, La lex mercatoria.., p. 32. Neste trabalho, utiliza-se tanto lex mercatoria quanto ius mercatorum em referência ao fenômeno. As referências utilizadas de autores anglo-saxões em geral fazem referência a law merchant.

${ }^{252}$ C. SCHMITTHOFF, International Business Law..., pp. 137 e ss.

${ }^{253}$ H. J. BERMAN; C. KAUfMAN, The Law of International Commercial Transactions (Lex Mercatoria), in Harvard International Law Journal, Cambridge, 1978, p. 221-77.

${ }^{254}$ F. OSMAN, Les principes généraux de la lex mercatoria..., 1992, p. 299.

${ }^{255}$ Também J. BART, La lex mercatoria au moyen age, pp. 10-1, observa que não há na Idade Média texto que faça referência à lex mercatoria, mas que fazem referência a "negociandi usus, jus mercatorum mercatorium, ou encore - mercati, jus nundinarum, jus et consuetudo, consuetudo fori sive mercati" tradução mais adequada seria direito de mercado, em vez de direito do mercado.

${ }^{256}$ M. FORTUNATI, La lex mercatoria..., pp. 32 e ss.
} 
origine essa sembra infatti riferirsi non ad una uniforme disciplina giuridica commerciale, sconosciuta fino al XVII secolo, ma esclusivamente a privilegi procedurali garantiti ai mercanti nel campo del processo civile. Si sarebbe tratatto quindi di una procedura speciale spedita, adatta alle necessita di uomini che non potevano aspettare i tempi ordinari del common law. In questo senso, il termine è utilizzato nel Fleta (opera giuridica composta presumibilmente intorno alla prima metà del XIV secolo da un giudice confinato nel carcere londinese Fleet) e nel medesimo significato appare nel Red Book of Bristol, dove la common law, descritta come la madre della lex mercatoria, dota la propria figlia di determinati privilegi che nel loro complesso si riferiscono a procedure più veloci e a metodi simplificati di esperimento delle prove”. Apenas a partir do século XVII, law merchant passou a ter o sentido 'moderno' na Inglaterra, com o tratado “Lex Mercatoria or the Ancient Law-Merchant", de 1622 de Gerard Malynes, publicado em Londres ${ }^{257}$.

FORTUNATI observa que o termo lex mercatoria é explicitamente utilizado como sistema de direito substancial para o comércio internacional a partir do século XVIII, ainda que com algumas divergências de opinião ${ }^{258}$.

De qualquer forma, ainda que o termo não tenha, de fato, sido cunhado à época em que tenha se desenvolvido, mas apenas séculos depois, não há razão para não utilização da expressão lex mercatoria para caracterizar esse fenômeno da sociedade pós-industrial. Contudo, sua utilização à semelhança do ius mercatorum medieval merece algumas reservas, com o destaque para algumas diferenças fundementais entre os dois momentos históricos ${ }^{259}$.

\subsubsection{A lex mercatoria medieval}

O desaparecimento do Império Romano, o domínio do Mediterrâneo pelos islâmicos e do Mar do Norte pelos normandos, bem como a descentralização política, com a formação de feudos como centros de poder, e a ascensão da Igreja Católica, fizeram com que houvesse grande retração do comércio $^{260}$.

\footnotetext{
${ }^{257}$ M. FORTUNATI, La lex mercatoria..., pp. 34-5.

${ }^{258}$ M. FORTUNATI, La lex mercatoria..., p. 35.

${ }^{259}$ J. BART, La lex mercatoria au moyen age..., pp. 10-22.

${ }^{260}$ A. C. CUTLER, Private Power..., p. 113, com base em Shepard Clough, recorda que comércio de longa distância existia no Adriático e no Mar do Norte e no Mar Báltico durante a primeira metade da Idade Média, mas que, na Europa Ocidental em geral, o comércio era moribundo.
} 
Pouco a pouco, a partir do século XI, cada vez mais pessoas passaram a se concentrar fora dos feudos, incluídos os mercadores e trabalhadores livres, como artesões. Com a intensificação do êxodo dos feudos, as antigas cidades passaram a ser reocupadas, como lugar de possibilidade de nova organização livre de convivência social $^{261}$.

Ao lado do crescimento das cidades (burgos), a realização das feiras foi crucial para a formação, desenvolvimento e universalização do ius mercatorum medieval, tanto em relação à criação de suas regras como na solução de suas disputas ${ }^{262}$. Na Inglaterra do século XIII, a Feira de Santi Ives teve grande relevância, assim como, na França, a de Champagne nos séculos XII a XV e a de Lyon, nos séculos XV e XVI. Na Alemanha, as feiras se consolidaram entre os séculos XV e XVII.

Mas foi na Itália, principalmente em Veneza, Gênova, Pisa e Florença, em que o ius mercatorum (re-)surgiu em razão, segundo GOLDSCHMIDT, de 'l'antichissima civiltà...; le comunicazioni commerciali sempre mantenute e assecurate mercè trattati internazionali con Bisanzio e gli Stati mussulmani, specialmente dell'Africa settentrionale; le crociate, che promossero notevolemente il traffico diretto con l'Oriente, e condussero a un sorprendente risveglio della navigazione e dello scambio delle merci con i contenui trasporti di persone i beni, del commercio monetario con l'aumento e l'accresciuta circolazioni dei capitali in denaro, e alle fattorie e colonie, circondanti tutti il Mediterrâneo, delle città maritime, le quali nella politica avventurosa di quei tempi perseguivano e raggiungevano durevolmente soltanto scopi economici; finalmente il fatto che la curia papale riceveva dinaro da tutti i paesi d'Europa"263. Além disso, o comércio ainda foi favorecido por estradas boas, inclusive pela rede fluvial, principalmente na Itália setentrional, que servia a numerosos mercados e feiras.

\footnotetext{
${ }^{261}$ F. Galgano, Lex mercatoria, Bologna, Il Mulino, 2001, p. 29 e ss. Note-se, porém, que tal modo de produção não se limitava a comerciar os meros excedentes, como nos feudos. Ao mesmo tempo, embora livres, na medida em que os artesãos eram proprietários dos instrumentos de produção, não tinham acesso à matéria prima e ao mercado consumidor. Não eram assim livres para decidir o que produziam, assim como quantidade, preço e para quem produziam. Trabalhavam por encomenda, muitas vezes financiados pelos mercadores. A classe mercantil ascende econômica e politicamente. A separação entre o mercado da matéria prima e o mercado consumidor, fonte de lucro, é juridicizado. Na comunidade, os produtores, mais do que a produção em si, passaram a ser controlados, havendo proibição de buscar trabalho fora do território. O comércio é restrito à classe mercantil, isto é, aos membros da corporação de ofício.

${ }^{262}$ A. C. CUTLER, Private Power ..., p. 114.

${ }^{263}$ L. GoldSCHMIDT, Universal-geschichte des Handelsrecht, trad. it. de Vittorio Pouchain, Storia universale del diritto commerciale, Torino, Unione tipografico-editrice torinese, 1913, p. 118.
} 
Também, depois das moedas bizantinas e árabes, as moedas de ouro italianas, a partir do século XIII, se tornam o dinheiro mundial ${ }^{264}$.

Os mercadores que passaram a se estabelecer nas cidades, diferentemente dos antigos, eram politicamente ativos, dando origem não só a um modo de produção fora do modo de produção feudal ${ }^{265}$, mas também a uma nova forma de comunidade.

Foram sendo formadas as corporações de ofício ${ }^{266}$, em geral concentradas - na medida em que as menores tendiam a ser absorvidas pelas maiores -, que assumiram funções não só de auto-regulação, mas também de governo da comunidade em determinados temas ${ }^{267}$.

A classe mercantil era independente das autoridades políticas e soberanos locais, formando sua própria ordem jurídica, não fundada em um território $(\text { desterritorializada })^{268}$.

Assim, a classe mercantil (e respectivo direito) coexistia(m) com outras autoridades e direitos, tais como feudais, eclesiástico ou da respectiva cidade e, embora mais ou menos autônoma, tinha pontos de contato com tais ordens ${ }^{269}$.

Em uma ordem plural, os mercadores não estavam sujeitos às mesmas regras que os demais. O tratamento dado às relações locais de troca e as de "longa distância" (ou internacionais) era completamente diferente ${ }^{270}$.

Sobre aquelas pesava a influência da Igreja Católica e a proibição à usura, a teoria do preço justo e outras regras para proteção do consumidor ${ }^{271}$. Aliás, como já

\footnotetext{
${ }^{264}$ L. GOLDSCHMIDT, Universal-geschichte..., p. 122.

265 A. C. CUTLER, Private Power ..., p. 111, observa que "the law merchant created the property rights and entitlements that were quite inconsistent with medieval conceptions of property - entitlements that were more consistent with property relations that would be later associated with capitalism". Isto porque (pp. 108-9) "the medieval law merchant order contributed to the expansion of trade and commerce by devising and enforcing commercial transactions that avoided feudal restrictions on the mobility of capital and transmissibility of property".

${ }^{266}$ Vide L. GOLDSCHMIDT, Universal-geschichte..., p. 122.

${ }^{267}$ Fixavam, por exemplo, regras de concorrência, horários de trabalho, qualidades de produtos, preços, número de aprendizes e duração de aprendizados. F. GALGANO, Lex mercatoria, Bologna, Il Mulino, 2001, p. 35.

268 Algumas características da sociedade na Idade Média destacadas por P. GROSSI, L'Europa del Diritto..., pp. 11 e ss. são: caráter mais ordenativo que potestativo, pluralismo jurídico, poder político incompleto, o indivíduo só existe na medida da sociedade (uti socius e não uti singuli), existência de corpos/entes intermediários, complexidade comunitária muito fragmentada ("società di società"), fatualidade do direito, consuetudinária.

${ }^{269}$ A. C. CUTLER, Private Power ..., p. 112.

${ }^{270}$ Segundo A. C. CUTLER, Private Power ..., p. 109: “while local transactions were heavily regulated by political authorities, long-distance trade was largely immune to the application of local law and was governed by the law merchant".

271 Vide item 2.1.1 acima. Segundo A. C. CUTLER, Private Power ..., pp. 116-7, “...canon law presented...equity as a form of distributive justice", que implicaria correção da distribuição de riqueza, bem diferente da noção de eqüidade, essencial, para a classe mercantil, já que a "law merchant embodied
} 
observado, a Igreja Católica exerceu grande influência na adoção do princípio pacta sunt servanda pela classe mercantil, que acabou concedendo proteção e efeitos jurídicos a operações que não existiam nas cortes reais.

De maneira geral, a participação das autoridades políticas locais e religiosas limitava-se a, em troca do pagamento de tributos, conceder autorização para o comércio $^{272}$, organização e realização de feiras e mercados, assim como salvo-conduto para os mercadores em trânsito ou durante as feiras, isentando-os da lei local no desenvolvimento de suas atividades ${ }^{273}$.

Segundo Olgiati, o modelo medieval da nova lex mercatoria co-existia com formas de constituição política estatais, contando com garantia jurídica do privilégio da liberdade de se estabelecer e circular acordado com os outros poderes políticos locais ${ }^{274}$.

Inicialmente, para regular o comércio marítimo, a classe mercantil se baseou na Lex Rhodia, recebida pela Grécia e pelos romanos e transmitida para a Europa Ocidental, assim como no jus gentium romano para direito das obrigações. As cidades portuárias passaram então a criar compilações de regras de direito marítimo, como a Tavola Amalfitana, adotada por todas as cidades italianas e em vigor no Mediterrâneo até a segunda metade do século XVI ${ }^{275}$. As cidades do Atlântico, do Mar do Norte e Inglaterra adotaram os Rôle d'Oleron ${ }^{276}$. Mencione-se também a existência das Laws of

the Roman Law principle of deciding cases ex aequo et bono... equity is less a matter of distribution or redistribution and more a 'discretionary corrective' to be applied in specific cases so as to avoid the rigors and potential injustices of formal law”. Com a Reforma (p. 132), as restrições ao comércio local diminuíram, com a distinção entre cobranças e lucros permitidos e não permitidos.

${ }^{272}$ Por exemplo, em 1303, na Inglaterra, o rei Eduardo I promulgou a Carta Mercatoria, documento que proporcionava privilégios a certos mercadores estrangeiros para promover e proteger o comércio. Vide D. R. Coquillette, Incipit Lex Mercatoria, Que, Quando, Ubi, Inter Quos et de Qubius Sit - El Tratado de Lex Mercatoria en el Little Red Book de Brístol, in PETIT, Carlos, org., Del Ius Mercatorum al Derecho Mercantil - 3 Seminario de Historia del Derecho Privado, Sitges 28-30 de Mayo de 1992, Madrid, Marcial Pons, 1997, p. 160.

${ }^{273}$ A. C. CUTLER, Private Power ..., p. 109.

${ }^{274}$ V. OLGIATI, Lex mercatoria e communitas..., pp. 355-6. Segundo o autor, "Il pressuposto era quindi il raggiungimento di uno status ufficialmente accreditato e la risultante possibilità di far valere ragioni di scambio non sempre equitative e sinallagmatiche, dovendo i mercanti perseguire anche interessi e rapporti non meramente commerciali, bensì anche político-istituzionali”.

${ }^{275}$ Vide H. J. Berman; C. Kaufman, The Law of ..., p. 224; A. C. CuTler, Private Power ..., p. 113 e A. DAL Ri JúNIOR, História do Direito Internacional - Comércio e Moeda - Cidadania e Nacionalidade, Florianópolis, Fundação Boiteux, 2004., p. 47.

276 Segundo J. GILISSEN, Introduction historique au droit...., p. 274, Rôle d'Oleron "constituem a redacção de 24 julgamentos do tribunal marítimo desta ilha, provavelmente do século XII, de qualquer modo antes de 1286. Foram traduzidos em holandês, e incluídos no direito marítimo de Damme (anteporto de Bruges) pouco depois de 1300; depois, em 1487, no direito de Wisby, na realidade o direito das 22 cidades da Hansa, aplicado no Mar do Norte e no Mar Báltico". Vide também H. J. BERMAN; C. KAUFMAN, The Law of ..., p. 224, que datam os datam de 1150. 
Wisby, no mar Báltico ${ }^{277}$, e o Llibre del Consolat de Mar, coleção, redigida no século XIII, de costumes marítimos observados pela corte consular de Barcelona ${ }^{278}$. Estas regras e costumes, que cuidavam de direito marítimo e também de contratos de transporte marítimo de carga, espalharam-se para outros centros comerciais.

Ao mesmo tempo, as demais cidades estavam criando regras para comércio terrestre em feiras e mercados na Europa.

É assim que, fundado nas regras relativas ao comércio marítimo e ao comércio terrestre, o ius mercatorum nasce como criação da própria classe mercantil. Segundo BERMAN e KAUFMAN, a lex mercatoria governava uma classe específica (os mercadores) em lugares especiais (feiras, mercados e portos) ${ }^{279}$. Para CUTLER, o caráter distintivo da lex mercatoria medieval reside na natureza essencialmente auto-regulatória da classe mercantil, tanto na criação do direito (sujeitos e fontes) quando na solução de $\operatorname{disputas}^{280}$

Cuidava dos direitos e obrigações no exercício da profissão, de maneira geral, sendo que as questões que extrapolassem as atividades profissionais, com algumas exceções, estavam submetidas a outros ordenamentos jurídicos ou sistemas de normas. O contrato, objeto essencial do ius mercatorum, passou a se desvincular da propriedade, tornando-se um ato de especulação e um instrumento para realização do lucro ${ }^{281}$. A lógica, portanto, era que fossem realizadas tantas transações quanto possíveis, com a maior segurança jurídica factível ${ }^{282}$, por isso a importância de um sistema, tanto na criação quanto na solução de disputas, que fosse capaz de lidar com os padrões informais, céleres e flexíveis da classe mercantil.

${ }^{277}$ C. SCHMitTHOFF, International Business Law..., p. 3. e H. J. Berman; C. KAUfMAN, The Law of ..., p. 225.

${ }^{278}$ H. J. Berman; C. Kaufman, The Law of ..., p. 225 e A. DAl Ri Júnior, História do Direito Internacional..., p. 47.

${ }^{279}$ H. J. BeRMAN; C. KAUfMan, The Law of ..., p. 225.

${ }^{280}$ A. C. CUTLER, Private Power ..., p. 110.

${ }^{281}$ F. GALGANO, Lex mercatoria..., p. 40. O autor (p. 41) anota ainda que "il nuovo principio della libertà di forme interpreta oposte esigenze di moltiplicazione della ricchezza, di valorizzazione del capitale, commerciale: il mercante deve, incessantemente, comperare e rivendere; il suo proffito è tanto maggiore quanto più compera i rivende; l'interesse che il diritto protege è l'interesse alla conclusioni degli affari: non l'interesse di chi, vendendo dispone di un proprio bene o l'interesse di chi, comperando, dispone del proprio denaro, ma l'interesse di chi, professionalmente, compera e rivende e tiene, comunque, alla conclusione della maggiore quantità possibile di affari". O fenômeno é distinto do que ocorria na sociedade romana, estamental e fundiária, em que o fundamento de riqueza era propriedade de terras e, como tal, o corpo de regras disponíveis à época, assim como o contrato, funcionava mais como meio de conservação de riqueza do que como meio de sua circulação.

${ }^{282}$ No passado, a troca era "entre presentes e por coisas presentes", já que a maior circulação das riquezas e aumento do volume dos negócios exigem maior segurança e previsibilidade jurídica na medida em que o "crédito, porém, é uma promessa de coisas futuras", cf. JOSÉ REINALDO DE LIMA LOPES, O Direito na História...,p. 397. Nessa lógica, o sistema passa a proteger não mais o devedor, mas sim o credor. 
As fontes do ius mercatorum eram os estatutos das corporações de ofício, os usos mercantis e os precedentes das cortes dos mercadores ${ }^{283}$.

Os usos eram a principal fonte do ius mercatorum ${ }^{284}$, absolutamente essenciais para o direito marítimo. Foram os usos, propagados principalmente nas feiras, que universalizaram diversas operações e institutos comerciais (e.g. letras de câmbio) $)^{285}$.

CUTLER acentua a importância do desenvolvimento de um sistema muito eficaz de adjudicação e execução privada para o ius mercatorum. Embora houvesse outras cortes para as quais recorrer (como a eclesiástica, as cortes comerciais ou, na Inglaterra, a common law), as pretensões da classe mercantil somente eram (e conseguiriam ser) garantidas nas cortes criadas pela própria classe mercantil (curia mercatorum $\left.{ }^{286}\right)^{287}$.

Compostas pelos próprios mercadores e denominadas de court of pie-powder ${ }^{288}$, as cortes eram estabelecidas, por consentimento real, com definição da respectiva jurisdição, nas próprias feiras, mercados e cidades portuárias ${ }^{289}$.

Uma das características essenciais do ius mercatorum é o fato de constituir ordem jurídica não vinculada a um Estado ou território específico, na medida em que tende a superar os limites territoriais, razão pela qual usualmente se refere ao 'universalismo' desse direito. ${ }^{290}$

${ }^{283}$ F. GALGANO, Lex mercatoria..., p. 37.

${ }^{284}$ H. J. BERMAN; C. KAUFMAN, The Law of ..., p. 225.

285 A. C. CutLer, Private Power ..., p. 126.

${ }^{286}$ F. GALGANO, Lex mercatoria..., p. 37.

287 A. C. CUTLER, Private Power ..., p. 133.

${ }^{288}$ Também denominadas de fair court, tolsey court ou piepoudre court. "Tolsey: a place at which tolls were collected; a tollbooth, a place where merchants meet. Esses tribunais eram, segundo D. R. COQuILletTe, Incipit Lex Mercatoria...., p. 155, "the lowest and at the same time the most expeditious court of justice known to the law of England. Is the court of piepoudre, curia pedis pulverizanti: so-called from the dusty feet of the suitors: or according to Edward Coke, because justice is there done as speedily as dust can fall from the foot". A. C. CUTLER, Private Power ..., p. 133, relata que "the origin of the name 'pie-powder' ('pieds poudreux' in French) is somewhat in dispute. Some attribute it to the fact that in fair courts justice was administered as 'speedily as the dust could fall or be removed from the fee of litigants', while others attribute it to the fact that 'the court was frequented by chapmen with dusty fee, who wandered from mart to mart"'. C. GROSs, The Court of Piepowder, in The Quarterly Journal of Economics, v. 20, n. 2, 1906, p. 231, cf. disponível [on-line] in http://www.jstor.org/stable/1883654 [20.4.2009] e C. SCHMitThofF, International Business Law..., pp. 23-4, observam que a explicação de que a denominção decorria da rapidez da justiça é mais imaginativa do que etimologicamente correta, já que "piepowder" vem do francês "prudhommes". Segundo J. R. DE LIMA LOPES, O Direito na História...,p. 78, a expressão significa "mercadores de pé empoeirados, porque viviam viajando".

289 A. C. CUtLer, Private Power ..., p. 134. A autora (p. 135) afirma que, em geral, as guildas não exerciam jurisdição ordinária. Disciplinavam seus membros, impondo embargos contra autoridades políticas que não tivessem respeitado direitos de propriedade de seus membros.

${ }^{290}$ Segundo J. BART, La lex mercatoria au moyen age..., pp. 22, para quem não há paralelo entre a antiga e a nova lex mercatoria paralelo, "les jus mercatorum s'est forme et cristalissé de la même manière que le reste du droit, enfermé dans le limites territoriales des seigneuries, villes et principautés, même si l'emergence de principes commun s'est produit plus tôt que dans d'autres domaines. Malgrè tout, chaque foire conserve sa propre réglementation, ses propres status, approuvés ou concédés par l'autorité publique locale". No mesmo sentido, a respeito da Inglaterra, vide S. E. SACHS, From St. Ives to cyberspace - the 
O "internacionalismo medieval" ${ }^{291}$ da lex mercatoria tem, segundo SCHMitThOFF, quatro causas principais: caráter unificador do direito das feiras, universalismo dos usos marítimos, as cortes específicas com competência específica para disputas comerciais e as atividades do notário público, que, segundo o jurista inglês, eram "that ubiquitous and versatile mediaeval practitioner in whose hands lay a good deal of commercial legal work". SchMitThOFF relata que, a partir de 1326, os contratos na feira de Champagne deveriam ser feitos na forma notarial. Da metade do século XIII em diante, contratos notariais eram comuns na Itália e, em Marselha, há relatos de que um notário fez mais de 1000 contratos em $1245^{292}$.

Mesmo com variações locais no conteúdo do ius mercatorum ${ }^{293}$, para CUTLER a universalidade nos princípios fundamentais pela Europa autorizam a caracterização de um direito comum da classe mercantil.

\subsubsection{Nacionalização da lex mercatoria}

A centralização política e a formação dos Estados modernos ${ }^{294}$ levaram à nacionalização e localização ${ }^{295}$ do ius mercatorum. Pouco a pouco, os monarcas compreenderam a importância do comércio internacional para o fortalecimento e sustentação do poder político.

modern distortion of the medieval law merchant, in American University International Law Review, v. 21, n. 5, 2006, pp. 685-812. O. VOLCKART, Are the Roots of the Modern Lex Mercatoria Really Medieval?, in Southern Economic Journal, v. 65, n. 3, 1999, pp. 427-450, cf. disponível [on-line] in http://www.jstor.org/stable/1060808 [20.4.2009], afirma que as corporações de ofício se destinavam mais a prover segurança física do que desenvolver um corpo de regras, por isso, conclui que a existência de instituições comerciais universais na Idade Média tem sido superestimada. C. GRoss, The Court of Piepowder..., p. 245, ao contrário, afirma a existência da nova lex mercatoria, mas indica que há pouco material histórico relacionado a regiões fora Itália.

${ }^{291}$ A. C. CUTLER, Private Power ..., p. 108.

292 C. SCHMiTTHOFF, International Business Law..., pp. 22-4. É plausível um paralelo entre esses contratos notariais e os contratos-tipo ou contratos-padrão contemporâneos, tratados no item 3.5.2.

${ }^{293}$ O que, como se verá no item 3.6., reflete a existência de lex mercatoria setorial. M. FORTUNATI, La lex mercatoria..., p. 41, ressalta, porém, sugerindo a revisão de alguns pontos assentados e em geral aceitos a respeito do tema, que "sopratutto, il mondo giuridico ed economico continentale non ha mai conosciuto in passato, ne utilizzato un corpo normativo organico che vada sotto il nome di lex mercatoria, che appare cosi uma costruzione tutta di stampo anglosassone.... Nel continente um diritto sostanziale chiamato lex mercatoria non compare: si sono conosciute ed applicate delle consuetudini mercantili - talvolta di stampo locale, talvolta, in virtù di processi di uniformazione o di inglobamento nella giurisprudenza e nella dottrina di diritto commune, dotate di un raggio operativo più ampio -, quase sempre utilizzati come codice etico e morale cui gli operatori commerciali si sentono legati, ma il cui valore e significato vanno recuperati e correttamente ricostruiti nella loro portata storica, politica ed economica".

${ }^{294}$ Vide item 2.1.

295 A. C. CUTLER, Private Power ..., p. 108. 
Como salienta Galgano, "il diritto diventa, nelle classificazioni dei giuristi dello Stato assoluto, diritto pubblico", passando a ser, de acordo com Domat, matéria que diz respeito ao governo e à política geral do Estado"296.

Assim, com o pensamento mercantilista ${ }^{297}$, o direito positivo ${ }^{298}$ foi eleito o meio mais adequado para regular o comércio internacional, em franca expansão, também em razão do crescente aprimoramento das técnicas produtivas. Iniciou-se um formalismo crescente em relação às fontes de direito, seja em relação ao meio de produção do direito, seja quanto a seus agentes produtores ${ }^{299}$.

Ao lado da nacionalização e da localização do ius mercatorum, houve, portanto, a substituição, como fonte primária do direito, dos usos pela lei.

Paralelamente, a solução de disputas, bem como a execução de decisões, se tornou função da esfera pública ${ }^{300}$. Além de ser uma realização política, CUTLER afirma que "the geographic expansion of commercial relations rendered the self-enforcement system of merchants inadequate. The collection of information regarding the creditworthiness and honesty of merchants became more expensive. The sanctions of market exclusion and loss of reputation became difficult to enforce as markets proliferated in number, as commerce extended to faraway places, and the practice of simultaneous exchange in markets was replaced by nonsimultaneous exchanges over time and distance. The imposition of bankruptcy and the enforcement of agreements

\footnotetext{
${ }^{296}$ F. Galgano, Lex mercatoria..., p. 76. Com efeito, C. SCHMitTHOFF, International Business Law..., p. 25 , lembra que a incorporação do direito comercial ao direito nacional, na França, se deu com a Ordonance sur le commerce de Luis XIV, de 1673, e a Ordonance de la marine de Colbert de 1681. A. DAL RI JÚNIOR, História do Direito Internacional..., pp. 77 e ss., menciona regulamentações de 1644, com tarifa protetora sobre os têxteis, de 1659, com a criação de imposto sobre as embarcações estrangeiras, da década de 70 sobre o comércio de cereais. Na Inglaterra, o autor menciona o segundo Navigation Act de 1660.

297 "A uma linha de pensamento e de ação que se revela durante dois séculos pelo menos (séculos XVI e XVII), unindo política e economia na teoria e na prática, não se pode pedir unidade e plena coerência em seu desenvolvimento; nem a quem tente acompanhar sua evolução... A compreensão do Mercantilismo, mais do que com uma definição, pode ser facilitada com a determinação dos objetivos comuns ao pensamento e à ação dos mercantilistas, objetivos, em geral, sumamente genéricos, tanto no século XVI, como no XVII, tanto na Itália como na Alemanha, França, Espanha e Inglaterra, ultrapassando as barreiras políticas, culturais e religiosas.”, cf. N. BoBbio; N. MATEUCCI; G. PASQUINO, Dizionario di Politica..., pp. 745-6.

${ }^{298}$ A implementação das políticas estatais não se deu de maneira uniforme, variando de país para país, conforme condições e tradições locais. A. C. CutLer, Private Power ..., p. 149, observa ainda que, diferentes, as políticas eram unidas pelo reconhecimento crescente do papel de questões econômicas para determinação do poder nacional. Este reconhecimento é ligado ao aparecimento do capitalismo e expansão econômica da Europa.

${ }^{299}$ A. C. CuTLER, Private Power ..., pp. 141-2. A autora (p. 147) relata que, segundo estimativas, o comércio britânico tenha crescido $500 \%$ do século XVII para o século XVIII. Fenômeno similar ocorreu na França, mas mais concentrado no século XVIII e na Holanda, no século XVII.

${ }^{300}$ Segundo A. C. CUTLER, Private Power ..., pp.176-7, "another way of framing the centrality of state enforcement is to consider that delocalized transactions must ultimately be localized in a system of legitimate legal compulsion in order to be enforced".
} 
became the prerogatives of states and thus contingent upon national intervention as states adopted laws and procedures governing the enforcement and execution of commercial agreements" ${ }^{301}$.

Percebe-se, assim, que este movimento foi também apoiado pela classe mercantil, na medida em que a monarquia absoluta e a economia mercantilista a fortalecem $^{302}$. OLGIATI afirma que a lex mercatoria moderna emergiu no curso das guerras européias de conquista colonial, havendo sustento direto, técnico, político e militar por parte do Estado ${ }^{303}$.

Ocorre que, ao passo que a classe mercantil historicamente se propunha como classe cosmopolita, a localização do ius mercatorum transformou um direito universal em nacional. Além disso, a perda da força política da classe mercantil não era condizente com a ascensão econômica da burguesia ${ }^{304}$. De acordo com BENSON, "the law merchant did not die. It changed in the seventeenth century, becoming less universal and more localized under the state influence; it began to reflect policies, interests and procedures of kings" 305 .

Pouco a pouco, porém, ainda que o interesse político fosse convergente com o interesse econômico da classe mercantil, a expansão da vida econômica fez com que a burguesia passasse a almejar um desenvolvimento autônomo da classe, refletido na cultura do século XVIII, com o nascimento do liberalismo, jus-naturalismo e direito natural $^{306}$.

A formação do Estado Nacional proporcionou à burguesia ascensão e dimensão de poder inéditos. Com o Código Comercial de Napoleão (1807) e demais atos

\footnotetext{
${ }^{301}$ A. C. CUTLER, Private Power ..., p. 142.

${ }^{302}$ F. GALGANO, Lex mercatoria..., p. 73.

303 V. OLGIATI, Lex mercatoria e communitas..., p. 356.

304 F. GAlGano, Lex mercatoria..., p. 73 e 87, lembra que com a centralização monárquica, as corporações passaram a ser instituições auxiliares do Estado e que, na França, por exemplo, a constituição de 1791 suprime as prerrogativas das corporações. O poder político se separa do poder econômico da burguesia. A. C. Cutler, Private Power ..., p. 167, recorda que a noção de um status distinto aos comerciantes foi substituída pela idéia de um status diferenciado aos atos de comércio.

${ }^{305}$ B. BENSON, The Spontaneous Evolution of Commercial Law, in Southern Economic Journal, n. 55, 1988-9, p. 653 apud A. C. CUTLER, Private Power ..., p. 144.

${ }^{306}$ F. Galgano, Lex mercatoria.., pp. 76-7. A. C. CUTLER, Private Power ..., p. 151, aponta que "as the rationale for mercantilist regulation came under attack, so too did the foundation for fixed prices and market regulations. The advent of laissez-faire theory and the values of economic liberalism in the eighteenth and nineteenth centuries and their adoption by the most powerful commercial states gave new meaning to the idea of merchant autonomy in contract law that reflected more fundamental transitions in world order". A autora (pp. 152 e ss.) menciona ainda o aparecimento da autonomia da vontade, liberação das restrições medievais, o processo de retirada do conteúdo moral da economia, parte do processo de separação entre economia e sociedade, principalmente após o recuo da Igreja Católica e as idéias reformistas relacionadas ao comércio. Vide item 2.1.1, sobre a evolução da autonomia da vontade e do papel do contrato.
} 
legislativos esparsos ${ }^{307}$, o direito comercial, mesmo regulado pelo Estado, volta a ser matéria de direito privado ${ }^{308}$. E, com isso, principalmente a partir da segunda metade do século XIX, os usos comerciais voltam a ter papel na criação do direito, ainda que subordinados à lei e ocupando o último lugar na hierarquia de normas.

De maneira geral, embora os interesses mercantis coincidissem em maior ou menor escala com os interesses políticos, a localização e nacionalização eram contrárias à própria essência cosmopolita, desterritorializada e universalizadora da lex mercatoria, principalmente quando acompanhadas da exclusão ou limitação do papel dos usos na criação e desenvolvimento de normas, impedindo a adaptação do direito a novas circunstâncias econômicas $^{309}$.

Assim, segundo CUTLER, "the second phase of the merchant law was marked by a decline in pluralism of both the sources and subjects of the law. Positive law replaced customary law as the primary source of law, though ... elements of commercial custom

\footnotetext{
${ }^{307}$ A. C. CutLer, Private Power ..., p. 168, menciona que o Código Comercial francês foi adotado ou copiado na Bélgica, Luxemburgo e colônias francesas.

${ }^{308}$ F. GALGANO, Lex mercatoria..., pp. 86 e ss. A incorporação do direito comercial às leis nacionais não foi uniforme, variando por razões políticas e sociais diferentes. Na Alemanha, foram importantes o Zollverein de 1834 e o primeiro esboço do Código alemão, de 186, adotado pela maioria dos membros da Confederação Alemã, incluindo Áustria e Prússia. A Alemanha adotou o Código Comercial em 1897, que aliás serviu de base para o direito comercial japonês - cf. C. SCHMitTHOFF, International Business Law..., p. 25. Já na Inglaterra, a incorporação se deu por motivos mais econômicos do que políticos. Segundo SCHMITTHOFF (p. 26), "in the middle of the eighteenth century and after the decline of the special commercial courts, it was an unrealistic anachronism for the common law courts to insist... on specific proof of universally accepted commercial custom... The reform which Lord Mansfield carried out... was ostensibly aimed at the simplification of commercial purpose, but was, in fact, much more: its purpose was the creation of a body of substantive commercial law, just, modern in character and, at the same time, in harmony with the principles of the common law...". Mansfield, no caso Pillans v. Mierop 3 Burr. 1663, 97 Eng. Rep. 1035 (KB 1765), afirmou que as normas da law merchant eram questões de direito a serem decididas pelos tribunais e não usos que devessem ser provados pelas partes, cf. A. C. CuTler, Private Power ..., p. 165. A autora (pp. 162 e ss.) afirma que, enquanto na Europa continental subsistiram tribunais do comércio, a perda de autonomia da classe mercantil foi maior nos estados de common law, especialmente na Inglaterra, onde os mercadores desapareceram como classe separada, com a absorção da justiça especializada pelas cortes de common law e pela absorção do direito material. Não obstante, os costumes continuaram a influenciar as regras que regiam as operações financeiras, securitárias e marítimas, deixando o conteúdo da regulamentação dessas matérias mais próximo do conteúdo da law merchant originária. Em alguns casos, as inovações da law merchant eram incorporadas à common law; já em outros, elas eram adaptadas para 'caber' na estrutura da common law e seus procedimentos. Durante o século XIX, áreas significativas do direito comercial foram codificadas com base nas decisões de common law. Em alguns casos, como por exemplo nas letras de câmbio, seguros e direito marítimo, costumes mercantis internacionais foram incorporados, preservando-se uma certa universalidade. Segundo CUTLER (p. 166 e ss.), nos EUA a law merchant começou a ser aplicada a partir do século XVIII, sendo levadas a cabo codificações ao longo dos séculos XIX e XX. A legislação estadunidense foi baseada em modelos ingleses, razão pela qual as mesma comportava similares aproximações e desvios da lex mercatoria medieval em relação à Inglaterra. Pela expansão colonial e relações comerciais, complementa a autora, os padrões incorporados no direito comercial inglês foram transmitidos para o mundo.

${ }^{309}$ H. J. BeRMAN; C. KAUfMAN, The Law of ..., pp. 227-8.
} 
persisted. This created a tension between the localizing tendency of national positive law and the delocalizing tendencies of international commercial custom"310.

\subsubsection{Lex mercatoria contemporânea ${ }^{311}$}

A localização e nacionalização da lex mercatoria, com a secundarização dos usos comerciais, pouco acrescentou a sua estrutura e desenvolvimento. Embora tenha estabelecido bases importantes para algumas intersecções verificadas atualmente entre lex mercatoria e Estados, os efeitos negativos da lex mercatoria nacional (ou moderna) fizeram com que a classe mercantil voltasse a aspirar um direito cosmopolita, universal, desterritorializado - isto é, não fundado em um território específico.

De fato, como bem observa MARrella, "la nazionalizzazione del diritto provocò, in definitiva, la fine dell'uniformità di quel diritto che per secoli aveva dominato il commercio internazionale portando con se quelle differenze determinate delle esigenze locali, dallo spirito di sovranità e dalla mutevolezza della stessa legislazione statuale. Alla stessa legislazione statuale, infatti, si richiedavano riforme, leggi speciali e revisioni che produressero un ulteriore e progressivo allontamento dalla lex mercatoria" ${ }^{312}$. Pouco a pouco, operou-se uma fratura entre direito e economia, o que é um importante dado a ser superado. A economia emerge como fenômeno específico apenas na modernidade, embora economia e política ainda tivessem um grau de interdependência ${ }^{313}$.

A revolução das técnicas produtivas, no final do século XIX e início do século XX, e, por outro lado, o extraordinário avanço nos meios de transportes e comunicação, possibilitaram um grande desenvolvimento no comércio internacional ${ }^{314}$. Este processo

\footnotetext{
310 A. C. CUTLER, Private Power ..., p. 163. A autora aponta ainda que os Estados substituíram os indivíduos como sujeitos de direito internacional, que cada vez mais foi associado ao direito internacional público. Observa também que (pp. 178-9) "during the early part of this phase, mercantilist principles informed state regulation of commerce, but later the advent of liberal political economy marked a shift in favor of a more permissive and facultative approach that stressed free-market principles. Public authorities thus generated laws and enforced disputes consistent with private law principles stressing freedom of contract...".

${ }^{311} \mathrm{O}$ contexto, fatores e desenvolvimento da globalização da sociedade pós-industrial e os reflexos do direito, apontados nos dois primeiros capítulos, devem ser considerados como base para o desenvolvimento da nova lex mercatoria. Neste item, são destacados alguns aspectos específicos daqueles processos mais diretamente relacionados à nova lex mercatoria.

${ }^{312}$ F. MARRELla, La nuova lex mercatoria..., p. 76.

${ }^{313}$ M. R. FERRARESE, Le istituzioni della globalizzazione..., pp. 22 e ss., salienta, aliás, que o caminho para a globalização começou com o fim do equilíbrio entre política e economia.

${ }^{314}$ Vide, para referência, números levantados pela UNCTAD sobre o crescimento das importações e exportações: http://stats.unctad.org/Handbook/TableViewer/tableView.aspx?ReportId=1903.
} 
de desenvolvimento intensificou-se ainda mais durante o último século, favorecido inclusive pelas duas grandes guerras, pelo surgimento dos Estados socialistas e comunistas, os quais passaram a figurar de forma importante nas relações internacionais de troca, por meio das empresas com participação estatal.

A economia da sociedade pós-industrial é também a economia das finanças ${ }^{315}$, em que boa parte das mercadorias se desmaterializa, fato este que "ne peut qu'accentuer l'impact des processus de formation de la lex mercatoria "316.

Observe-se que o direito comercial historicamente sempre tendeu à universalização, no sentido de superar limites territoriais. Neste contexto, refletido em um mercado potencialmente unificado, em escala global, é politicamente fragmentado pela existência dos Estados nacionais. FERRARESE adverte, porém, que, em razão das interações locais, "globalizzazione dell' economia non implica dunque unificazione dei regimi giuridici dei mercati, ma piuttosto crescente capacità di tali regimi di comunicare per convergere verso un allargamento degli scambi" ${ }^{\prime 317}$.

A própria existência de leis nacionais dá causa a particularismos jurídicos que não favorecem o comércio. A situação é agravada não só pela inadequação das leis nacionais $^{318}$, em razão de, em maior ou menor escala, o elemento dinâmico do direito comercial ter lhe sido retirado com a secundarização do papel dos usos comerciais, como também pela menor grau de certeza na exequiibilidade de contratos e decisões judiciais.

Além disso, a nacionalização do direito fez com que deixasse de existir um direito internacional. $\mathrm{O}$ direito é essencialmente um direito nacional e o direito internacional privado não é diferente. Há direito internacional privado brasileiro,

\footnotetext{
${ }^{315}$ F. GALGANO, La globalizzazione ..., p. 17. Vide, para referência, números levantados pela UNCTAD sobre crescimento das finanças e dos serviços: http://stats.unctad.org/Handbook/TableViewer/tableView.aspx?ReportId=1926 http://stats.unctad.org/Handbook/TableViewer/tableView.aspx?ReportId=1913.

${ }^{316}$ E. LOQUIN, Où en est la lex mercatoria..., p. 31.

${ }^{317}$ M. R. FERRARESE, Le istituzioni..., p. 70. Não haveria unificação em razão das interações em nível local, nacional ou regional.

318 A. C. CUTLER, Private Power ..., p. 30, comenta que "in some cases the compression of time and distance, associated with advances in technology and communications, renders commercial transactions instantaneous and simultaneous, creating a dynamism that makes traditional forms of unified law quite irrelevant and dated", fazendo com que se haja menos tempo para tomar decisões e criando a necessidade de respostas mais rápidas ou até instantâneas do direito.
} 
alemão, italiano e assim por diante ${ }^{319}$ e a existência de vários sistemas de direito internacional privado é um entrave ao comércio, como bem aponta GOLDMAN ${ }^{320}$.

Em relações jurídicas com um ou mais elementos estrangeiros (envolvendo fatos mistos ou multinacionais), surge naturalmente a questão da lei aplicável. O método clássico de resolução de conflitos de leis no espaço (direito internacional privado) localiza o conflito, submetendo as partes à aplicação da lei de um determinado país. Esta lei não só pode não ser adequada do ponto de vista de seu conteúdo, como pode não ser aquela prevista pelas partes. A situação se agrava quando não há a necessária certeza quanto ao foro competente, isto é, aquele que, na prática, decidirá o caso e quando a possibilidade de electio iuris é considerada, já que alguns países a admitem e outros não ${ }^{321}$.

Enfatize-se que incertezas em relação ao foro competente e à lei aplicável têm sido cada vez mais levadas em conta. Uma pesquisa realizada pela Câmara de Comércio Internacional revelou que $40 \%$ das empresas líderes no cenário mundial já deixou de realizar negócios em razão da insegurança quanto a estas questões ${ }^{322}$.

Por outro lado, a Guerra Fria e o mundo bi-polar, dividido entre os Estados de economia de mercado e os Estados de economia planificada, com as empresas estatais figurando nas relações comerciais internacionais, assim como os mega-contratos (principalmente de engenharia e construção de grandes obras) envolvendo relações Norte-Sul, são dados importantes a serem considerados para o distanciamento dos ordenamentos jurídicos nacionais, tanto em relação à solução de disputas, com fortalecimento da arbitragem, quanto na necessidade de um corpo autônomo de regras

\footnotetext{
${ }^{319}$ R. DAVID, Il diritto del commercio internazionale - un nuovo compito per i legislatori nazionali o una nuova lex mercatoria?, in Rivista di Diritto Civile, 1976, I, p. 578.

${ }^{320}$ B. Goldman, Frontières du droit... No mesmo sentido, por exemplo, M. J. Bonell, Un "codice" internazionale, p. 12, que afirma que "il solo fatto che esistano diversi diritti nazionali chiamati a disciplinare i contratti internazionale genera, inevitabilmente, un problema di conflitti di leggi.... Le incertezze e gli incovenienti che ne derivano sono fin troppo evidenti. A causa delle differenti norme di diritto internazionale privati dei vari Stati, le parti corrono il rischio di rimanere nell'incertezza in merito al diritto applicabile al loro contratto sino a quando non venga stabilito il foro competente...".

${ }^{321}$ Basta analisar as decisões dos tribunais brasileiros a respeito das cláusulas de eleição de lei e de eleição de foro. Em relação às primeiras, o artigo $9^{\circ}$ da Lei de Introdução ao Código Civil é interpretado como jus cogens, não derrogável pelas partes, sendo a electio juris desconsiderada, aplicando-se o princípio Lex loci regit actum. Já quanto ao foro, mesmo em casos de competência concorrente, interpretando o artigo 88 do Código de Processo Civil como regra de ordem pública, alguns julgados entendem que a cláusula de eleição de foro não tem o condão de afastar a apreciação da causa pelo juízo nacional, embora possa fundamentar o julgamento da causa por juízo estrangeiro. Como resultado, o foro e lei inicialmente planejados podem vir a ser desconsiderados, sendo aplicáveis regras distintas daquelas escolhidas pelas partes, com desfecho imprevisível.

${ }_{322}$ Jurisdiction certainty is essential in international contracts, Paris, 2.4.2008, disponível [on-line] in http://www.iccwbo.org/policy/law/iccef/index.html [05.01.2008].
} 
que pudesse em certa medida neutralizar as diferenças políticas e ideológicas reinantes $^{323}$.

A difusão da arbitragem internacional, aliás, é um outro fator relevante para a formação da nova lex mercatoria. SCHMITTHOFF afirma que “...the new law merchant, as an autonomous regulation, is founded on the complementary of party autonomy and arbitration" ${ }^{324}$. Não só este meio de solução de disputas tem sido considerado, pela própria comunidade mercantil, como o foro natural e mais apropriado para solução de disputas, como também os Estados deixaram de ser hostis à arbitragem como pouco a pouco foram incentivando o instituto.

CUTLER relata que na Inglaterra foi promulgada em 1697 uma lei prevendo a exeqüibilidade de laudos arbitrais, lei esta alterada em 1889 para garantir a exequiibilidade de acordos que submetessem disputas futuras à arbitragem. O estado de Nova Iorque, nos Estados Unidos, promulgou um ato em 1791 prevendo exeqüibilidade de laudos e compromissos arbitrais pelas cortes estatais ${ }^{325}$.

MARRELlA ressalta que o Protocolo de Genebra de 1923 relativo às convenções de arbitragem foi o primeiro passo de um longo caminho que, pela Convenção de Nova Iorque sobre o Reconhecimento e a Execução de Laudos Arbitrais Estrangeiros, de 1958, permitiu gradualmente o renascimento da lex mercatoria ${ }^{326}$.

Mais recentemente, deve ser destacada a importância da Lei-Modelo da UNCITRAL, de 1985, adotada por mais de 60 países e utilizada como base ou similar à lei de arbitragem de outros países, tais como o próprio Brasil. Aliás, interessante notar que, nos últimos 20 anos, uma grande parte dos países adotou a Lei-Modelo da UNCITRAL ou reformou suas leis ou promulgou novas leis sobre arbitragem ${ }^{327}$.

\footnotetext{
${ }^{323}$ Vide Y. L. FORTIER, New trends in governing law..., p.19. C. SCHMITTHOFF, International Business Law...., p. 28, afirma que 'a particular aspect - and value - of the rediscovered international conception of commercial law is that it represents a common platform for the jurists of East and West. The view is widely held, particularly by lawyers from the East, that ideological, political, or economic differences are no obstacle to the global uniformity of the law of international trade... These similarities (entre a regulação dos contraltos pelos sistemas jurídicos) have become more marked in recent years because in the countries of socialist economy foreign trade is now carried out on the level of private law". Vide Y. DEZALAY e B. GARTH, Merchants of Law as Moral Entrepreneurs..., in Law \& Society Review, v. 29, n. 1, 1995, pp. 45-6. Os autores recordam o tribunal de disputas entre os Estados Unidos e Irã, na Haia, e a importância e crescimento de Estocolmo como centro de arbitragem para disputas entre os países socialistas e os países capitalistas.

${ }^{324}$ C. SCHMITTHOFF, International Business Law...., p. 29.

${ }^{325}$ A. C. CUTLER, Private Power ..., pp. 175 e ss.

${ }^{326}$ F. MARRELLA, La nuova lex mercatoria..., pp. 80-1.

327 Cf. [on-line] isponível in
}

http://www.uncitral.org/uncitral/en/uncitral_texts/arbitration/1985Model_arbitration_status.html [15.12.2009]. 
A difusão internacional das práticas contratuais do mundo dos negócios e também dos usos comerciais internacionais, com influência fundamental de associações comerciais, que proliferaram desde o século XVIII, é apontado como outro fator determinante para a formação da nova lex mercatoria ${ }^{328}$.

Contribuiu também para o aparecimento do novo ius mercatorum a deficiência de outras tentativas de prover à classe mercantil e ao comércio internacional instrumentos apropriados para as relações de troca, já em consideração às inadequações apontadas $^{329}$. LoQUIN aponta que “en l'absence d'une coopération interétatique significative, ces nouveux espaces (os espaços imaterias) ne peuve que s'autoreguler, ${ }^{330}$.

A primeira estratégia consistiu na adoção de convenções internacionais de direito uniforme. No entanto, em razão de impedimentos políticos, da burocracia na sua internalização pelos Estados, na sua subseqüente rigidez, tais instrumentos são de número reduzido e de ação limitada ${ }^{331}$.

Em 1992, o Instituto Asser listou 120 instituições arbitrais pelo mundo. Atualmente, segundo o International Trading Centre UNCTAD/OMC, seriam ao menos 175 instituições arbitrais, separadas por região, cf. disponível [on-line] in http://www.jurisint.org/en/ctr/2_1_2.html [15.12.2009]. Para um apanhado das principais instituições arbitrais, vide A. FRIGNANI, L'arbitrato commerciale internazionale - v. XXXIII - Trattato di diritto commerciale e di diritto pubblico dell'economia diretto da Francesco Galgano, Padova, Cedam, 2004, pp. 42 e ss.

${ }^{328}$ F. GALGANO, Lex mercatoria..., p. 238. B. GoldMAN, Frontières..., p. 179, relata que os usos profissionais comuns da venda uniforme ressurgiram no século XIX e cita como exemplo a criação da London Corn Trade Association, em 1877 e reformulada em 1886. Relata, ainda, que essa associação tornou disponível os contratos-tipo, que posteriormente se difundiram em tantos outros domínios do comércio internacional. A. C. CUTLER, Private Power ..., pp. 175 e ss. aponta que tais associações ofereciam serviços arbitragem para seus membros. A autora menciona a associações como Liverpoool Cotton Exchange, London Stock Exchange e London Corn Trade Exchange e Coffee Trade Association. Nos Estados Unidos, principalmente no final do século XIX, surgiram New York Stock, Produce, Mercantile, Cotton, and Coffee and Sugar Exchanges, Chicago Board of Trade, St. Louis Merchants' Exchange, Philadelphia Commercial Exchange, Kansas City Board of Trade, Milwaukee Grain Exchange. Grain and Feed Dealers Association, National Hay Association, the National Cotton Seed Products Association, the American Seed Trade Association. O papel dessas entidades comerciais, da difusão dos usos e contratos-tipo será tratado nos itens 3.5.2 e 4.1.2.1.

329 À luz de todas as insuficiências dos instrumentos vinculantes de direito uniforme M.J. BonELL, The UNIDROIT Principles of International Commercial Contracts and CISG - Alternatives or Complementary Instruments, in Uniform Law Review,1996, p. 29, lembra, por exemplo, que "it was both the merits and shortcomings of CISG which prompted UNIDROIT to embark a Project as ambitious as the Principles. In other words, if it had not been for the world-wide adoption of an international uniform sales law like CISG, any attempt at formulating rules for international rules for international commercial contracts in general would be unthinkable. At the same time, it was precisely because the negotiations leading up to CISG had so amply demonstrated that this Conventions was the maximum that could be achieved at the legislative level, which caused UNIDROIT to abandon the idea of a binding instrument and instead to take another road for its own Project".

${ }^{330}$ E. LOQUIN, Où en est la lex mercatoria..., p. 31.

${ }^{331}$ M. J. BonELL, Un “codice” internazionale ..., p. 14, observa que “...tali strumenti rischiano di restare poco più che lettera morta, e/o presentano, normalmente, un carattere piuttosto framentario" já que apenas regulam os efeitos decorrentes de alguns contratos e muitas vezes apresentam lacunas. Além disso, no longo prazo, corre-se o risco de diferenças na aplicação dos instrumentos por cada um dos países, em 
As leis-modelo, sem olvidar o sucesso de algumas, também devem superar dificuldades similares às do direito uniforme. Acrescente-se que tanto as leis-modelo quanto os instrumentos de direito uniforme são internalizados e tornam-se, portanto, direito nacional, perdendo seu elemento dinâmico. ROSETT ressalta que "the drafters of these codifications tend to look on harmonization as an event that happens once and for all. They see their codes as monuments that will change, that will be self-executing in a unified way throughout the world. As times change and the law does not, codification becomes the enemy of substantive reform". ${ }^{332}$.

É assim que Goldman ${ }^{333}$, Schmitthoff ${ }^{334}$, David ${ }^{335}$ identificam uma nova lex mercatoria, afirmando que "si forma così un corpo di regulae iuris che gli operatori economici sono indotti a osservare sulla previsione che, in caso di controversia, verrano aplicate ai loro rapporto commerciale", de natureza transnacional, cuja função primordial é "di superare la discontinuità giuridica da questi provocati" ${ }^{336}$ (pluralidade de Estados que dividem politicamente o mercado).

\subsubsection{Diferenças entre lex mercatoria medieval e contemporânea (ou nova lex mercatoria)}

\footnotetext{
razão de interpretações à luz da própria cultura e tradição jurídica, impedirem a consecução do ideal do direito uniforme. BONELL (p. 16) recorda que "...le convenzioni internazionali o leggi uniformi sono spesso soggette ad interpretazione che differiscono da paese a paese e, in caso di lacune, vengono integrate sulla base di principi e di norme tratti dai rispettivi diritti interni non unificati”. À luz de todas as insuficiências dos instrumentos vinculantes de direito uniforme M.J. BONELL, The UNIDROIT Principles of International Commercial Contracts and CISG - Alternatives or Complementary Instruments, in Uniform Law Review, 1996, p. 29, tratando da CISG, uma das mais importantes convenções para o comércio internacional, e os Princípios UNIDROIT, expressão da nova lex mercatoria, como se verá no item 3.5.1.1 deste capítulo, lembra por exemplo que "it was both the merits and shortcomings of CISG which prompted UNIDROIT to embark a Project as ambitious as the Principles. In other words, if it had not been for the world-wide adoption of an international uniform sales law like CISG, any attempt at formulating rules for international rules for international commercial contracts in general would be unthinkable. At the same time, it was precisely because the negotiations leading up to CISG had so amply demonstrated that this Conventions was the maximum that could be achieved at the legislative level, which caused UNIDROIT to abandon the idea of a binding instrument and instead to take another road for its own Project".

332 A. RoseTT, Unification, Harmonization, Restatement, Codification and Reform in International Commercial Law, in The American Journal of Comparative Law, 1992, p. 688.

${ }^{333}$ B. GOLDMAN, Frontières..., p. 177-92.

${ }^{334}$ C. SCHMITTHOFF, International Business Law....

${ }^{335} \mathrm{R}$. DAVID, Il diritto del commercio internazionale....

${ }^{336}$ F. GALGANO, Lex mercatoria..., pp. 238-9.
} 
A própria existência da antiga lex mercatoria, como conjunto de regras de direito material é controvertida. A comparação ou a idéia de continuidade entre os dois fenômenos é ainda mais ${ }^{337}$.

GALGANO afirma que a utilização do termo lex mercatoria justifica-se porque "l'espressione ha origine colta: vuole alludere alla rinascita, in epoca moderna, di un diritto altrettanto universale quanto fu universale il diritto dei mercanti medioevoli" ${ }^{338}$.

O jurista italiano afirma, também, que o direito comercial retoma a idéia antiga de um direito despolitizado, ou seja, formado pela própria classe mercantil sem mediação política, e almejando uniformidade além das fronteiras estatais, independentemente de fragmentação política ${ }^{339}$. Ou seja, redescobre-se a internacionalidade - ou melhor, a transnacionalidade - do direito comercial.

Para CUTLER, 'the significant role that private authority has played in the creation and enforcement of merchant law in medieval and modern phases of the law merchant suggests considerable symmetry and unity between periods..." "340. A autora observa também que, além da autonomia na criação das regras de direito ${ }^{341}$, estão presentes no desenvolvimento da nova lex mercatoria a celeridade e informalidade de suas normas procedimentais, tal qual na lex mercatoria medieval ${ }^{342}$.

Não são raras as vezes em que, recentemente, a tentativa de explicação do direito nos dias atuais e, principalmente, da nova lex mercatoria passe por ou seja fundada em moldes medievais ${ }^{343}$.

\footnotetext{
${ }^{337}$ Vide n.r. 282.

${ }^{338}$ F. GAlgAnO, Lex mercatoria..., p. 238. Segundo H. J. Berman; C. KAUfMAN, The Law of ..., p. 273, "although it has been argued by some that the 'new law merchant' is an entirely different entity from its medieval predecessor, it seems more accurate to say that the 'old' law merchant of the eleventh to sixteenth centuries never died but continued to develop, even in the heyday of nationalism as part of the jus gentium". Também EVERARdo NóBrega QueIROZ, O Princípio da Boa-fé Objetiva..., p. 79, considera impróprio se atribuir à lex mercatoria nos dias atuais o atributo de novo, na medida em que não haveria diferença fundamental no que concerne ao caráter dos princípios fundamentais da lex mercatoria, mas diferenças decorrentes do desenvolvimento dos usos do comércio internacional, evolução das ordens públicas nacionais e internacionais e extensão das aplicações.

${ }^{339}$ F. Galgano, Lex mercatoria..., pp. 12-3.

${ }^{340}$ A. C. CUTLER, Private Power ..., pp. 105-6.

341 Esta autonomia pode ser traduzida na espontaneidade, isto é, na criação de regras jurídicas sem mediação político-legislativa.

${ }^{342}$ A. C. CUTLER, Private Power ..., p. 288. Especificamente em relação à arbitragem, Y. DEZALAY e B. GARTH, Merchants of Law as Moral Entrepreneurs..., p. 29, advertem que a arbitragem comercial internacional não é mais a mesma, se comparada com suas características nos anos 70 do século passado. Segundo os autores, “'arbitration' has become increasingly formal and more like U.S. style litigation as it has become more successful and institutionalized". A. FRIGNANI, L'arbitrato commerciale internazionale..., pp. 292-3 lamenta a procedimentalização da arbitragem.

${ }^{343}$ V. FERRARI, Quesiti sociologici sulla lex mercatoria..., p. 9, por exemplo, afirma que "divenuti incerti i confini, erose le certezze del positivismo giuridico statalistico degli ultimi tre secoli, è venuto naturale
} 
Entretanto, um contexto econômico, político e social fundamentalmente diferente não autoriza tratar o fenômeno da nova lex mercatoria e da antiga de maneira uniforme.

A redefinição e compressão de critérios espaço-temporais, como a criação de espaços virtuais (ou não-lugares), além do volume e dimensão do comércio internacional dos dias atuais por si só seriam suficientes para diferenciar os dois fenômenos ${ }^{344}$.

FERRARESE aponta que "quel pluralismo giuridico (medieval) trovava origine in diversi ordini sociali costituiti, nella varietà dei gruppi di appartenenza, nella sedimentazione di una ratio di tipo consuetudionario... il pluralismo odierno è riconducibile più ai cambiamenti indotti dai venti del capitalismo in evoluzione che alle sedimentazioni consuetudinarie prodotte dalla storia"345.

Por exemplo, ainda que tanto na antiga quanto na nova lex mercatoria os contratos-padrão exerçam papel fundamental na difusão dos usos, na nova lex mercatoria tais contratos estão sempre mais sujeitos e prontos a serem alterados, de forma cada vez mais veloz e de acordo com exigências mutáveis ${ }^{346}$.

Algumas diferenças pontuais podem ser apontadas em relação ao conteúdo das regras da nova lex mercatoria. O âmbito de aplicação da antiga abrangia questões societárias e falimentares, por exemplo. A nova, por sua vez, além de não compreender tais matérias, também não tem regras sobre a transferência de propriedade de um bem móvel - basta recordar da Convenção de Viena sobre a Compra e Venda Internacional de Mercadorias (CISG), de 1980, que exclui de sua aplicação os efeitos do contrato sobre a propriedade. Por outro lado, a nova lex mercatoria abrange o comércio de bens culturais $^{347}$.

BART afirma que a própria idéida de relações econômicas internacionais é anacrônica e que o melhor seria identificar como relações intersenhoriais ou de comércio de longa distância ${ }^{348}$.

gettare un ponte verso il mondo anteriore, caratterizzato da entità politico-territoriali diverse dallo stato moderno, e segnalarne le analogie col presente".

${ }^{344}$ A. C. CUTLER, Private Power ..., p. 190.

${ }^{345}$ M. R. FERRARESE, Le istituzioni della globalizzazione..., p. 150.

${ }^{346}$ F. GAlgAno, Lex mercatoria..., p. 58, n. 27, com base em E. Roppo (Il contratto e le fonti del diritto, 2001).

${ }^{347}$ F. MARRELLA, La nuova lex mercatoria tra controversie..., p. 250. As relações da lex mercatoria se dão, principalmente, com a ordem internacional e com o Estado. Por exemplo, questões como capacidade das partes continuam a ser reguladas pelo direito estatal. A relação entre a lex mercatoria e os demais ordenamentos jurídicos, especialmente o estatal e o internacional, é objeto do item 4.2.

${ }^{348}$ J. BART, La lex mercatoria au moyen age..., p. 21. 
Mas a diferença fundamental está na presença do Estado. De fato, “...in the medieval trading world merchants engaged in foreign trade were autonomous by virtue of the absence of political authorities desirous or capable of disciplining their activities. Local political authorities did exercise very general control in granting trade charters, providing for the safe-conduct of merchants, and securing the peace of market and fairs...In contrast, today merchant autonomy operates with full support of state authorities" ${ }^{349}$, o que é um legado da segunda fase da lex mercatoria, a de sua nacionalização. MARRELLA observa que "se il declino dell'antica lex mercatoria iniziò con l'avvento dello Stato moderno, attraverso la statalizzazione (e la centralizzazione) delle fonti del diritto commerciale e del potere giurisdizionale in subiecta materia, oggi accade che la nuova lex mercatoria si sviluppa con la connivenza degli Stati ${ }^{350}$.

$\mathrm{Ou}$ seja, a autonomia e/ou espontaneidade da nova lex mercatoria tem dimensões muito diferentes daquelas existentes na antiga ${ }^{351}$. Os pontos de intersecção entre a ordem da classe mercantil e das demais ordens jurídicas eram menos freqüentes e, talvez, menos agudos.

\subsection{Atores da nova lex mercatoria}

Como visto no segundo capítulo, o direito transnacional, da sociedade pósindustrial, é caracterizado pela pluralidade de atores, tanto produtores quanto destinatários das regras, sejam estatais, supranacionais ou infra-estatais.

Como um tipo de direito transnacional a nova lex mercatoria é resultado da atuação de uma multiplicidade de atores, caracterizada pela relevância da esfera e autoridades privadas, com distinção menos clara entre público e privado, assim como

\footnotetext{
349 A. C. CuTLER, Private Power ..., p. 190. R. DAVID, Il diritto del commercio internazionale..., p. 588, bem observa que "la prima (lex mercatoria medieval) è sorta per supplire alle insufficienze di un diritto statuale, fatto per comunità essenzialmente rurali, ripiegate su se stesse e con un modo di vita conforme alla tradizione. Nessuna autorità pubblica si riteneva allora competente ad elaborare un diritto nuovo, e tale compito fu assunto dalla nuova comunità costituita dai 'mercanti', dotata di privilegi ad opera dei publici poteri. Oggi esiste dappertutto un 'legislatore', e Il diritto si identifica, nella maggior parti dei casi, con la volontà di costui".

350 F. MARRELLA, La nuova lex mercatoria tra controversie..., p. 251, de acordo com quem “innanzitutto, la nuova lex mercatoria si differenzia dalla antica perché, mentre quest'ultima si era sviluppata ai margini del sistema feudale, la prima nasce e si sviluppa nel cuore della società postindustriale. Inoltre, se lo ius mercatorum di Baldo o Bartolo prosperava in un'epoca segnata dall'atomizzazione del potere politico, il mondo della nuova lex mercatoria risulta sudivviso in Stati".

351 J. BART, La lex mercatoria au moyen age..., p. 21, "si la formulation latine exprimée il y a un cinquantaine d'années est un image évocatrice, elle ne saurait en aucun cas à nos yeux, être considérée comme un protrait fidèle d'un ancêtre médiéval. Il s'agit certes toujours de répondre aux exigences du développement des échanges, mais dans ces conditions qui ne peuve être rapprochées ni comparées".
} 
pela horizontalidade e relevância da relação centro/periferia e dicotomia formalidade/informalidade das regras jurídicas ${ }^{352}$.

FERRARESE, para quem os atores seriam jogadores do jogo jurídico, na medida em que são eles que dão existência à nova lex mercatoria como direito das possibilidades, observa que o direito transnacional da sociedade industrial impõe desafios de ordem quantitativa e qualitativa em relação aos jogadores.

Em termos quantitativos, adverte que o número cada vez maior de jogadores torna inviável seu elenco exaustivo. Já as características inéditas desses atores, em medida considerável privados, mas de relevância pública ou coletiva, com identidade institucional, implica uma alteração qualitativa, com conseqüente reorganização das fontes e do sistema de produção de normas ${ }^{353}$.

FERRARESE acrescenta que, de maneira geral, os atores privados podem ser classificados em três categorias: os entusiastas, os competentes e os interessados ${ }^{354}$. Os primeiros consistem nas organizações não-governamentais $(O N G s)$. Os competentes, por sua vez, são as burocracias internacionais e os especialistas que a elas prestam assistência, contribuindo com conhecimento e competência profissional, técnica ou científica. É comum a referência ao termo tecnocracia ou tecnocratas também ${ }^{355}$. Os interessados, por fim, são aqueles portadores de interesses econômicos, entre as quais se incluem, principalmente, empresas transnacionais, que, diferentemente dos entusiastas, são movidas por interesse egoístas.

Já DeZalay e TrubeK, ao tratarem da internacionalização do campo jurídico, “conjunto de todos os personagens que fazem, interpretam e aplicam a lei, transmitem

\footnotetext{
${ }^{352} \mathrm{O}$ escopo deste item é unicamente descritivo. A reflexão a respeito da societas ou communitas mercatorum, business community, transnational capitalist class ou mercatocracy como elemento constituinte da nova lex mercatoria e de sua ordem jurídica é objeto do item 4.1.3.3.

${ }^{353}$ M. R. FERRARESE, Le istituzioni della globalizzazione..., pp. 32-4.

${ }^{354}$ M. R. FERrARESE, Diritto sconfinato..., pp. 32-3. A terminologia é de M. Shapiro, Administrative Law Unbounded - Reflections on Government and Governance, in Indiana Journal of Global Legal Studies, 8, 2001, pp. 369-77.

${ }^{355}$ As implicações da tecnocracia serão tratadas no item 4.2. Segundo cf. N. BOBBiO; N. MATEUCCI; G. PASQuino, Dizionario di Politica, pp. 1233-6 "a noção de Tecnocracia está entre as mais ambíguas de todo o corpo conceptual das modernas ciências sociais. Entrada na linguagem científica no início dos anos 30, a palavra Tecnocracia designava, originariamente, os físicos-químicos e o papel que vinham assumindo no processo de desenvolvimento da sociedade de então. A partir daí, ela foi também utilizada para evocar por vezes o poder ou a influência de outras variadas categorias sócio-profissionais... Em primeiro lugar, a ambigüidade está na identidade dos atores evocados pela noção... Um segundo ... está na amplitude histórica do fenômeno tecnocrático... Um terceiro ... diz respeito à essência e à natureza do kratos de que são detentores os tecnocratas... Um último traço de ambigüidade ... é o que se refere ao enquadramento social dos tecnocratas... A sociedade da organização (programação e planejamento) é, na verdade, o verdadeiro ambiente que constitui o genus tecnocrático, enquanto que a terceira revolução (a da automação ou do cimputador) comporta mais a emergência de novas espécies tecnocráticas...
} 
conhecimentos jurídicos e socializam os jogadores que se encontram no jogo do campo", identificam as seguintes posições estratégicas ${ }^{356}$ : praticantes, que poderiam ser equiparados aos prestadores de serviços jurídicos; aplicadores da lei (juízes, árbitros, funcionários administrativos); guardiões da doutrina (acadêmicos); educadores, que socializam o conhecimento, tanto em ambiente acadêmico, como faculdades, e em ambientes de trabalho; e os reguladores morais, formais, como instituições confiáveis, comitês disciplinares, promulgadores de éticas jurídicas ou informais, relacionados, por exemplo, a influências de ambiente de trabalho, redes sociais informais.

OSMAN afirma que são os Estados, as organizações internacionais governamentais e os profissionais que elaboram a lex mercatoria ${ }^{357}$. Segundo FRIGNANI, são todos pessoas físicas e jurídicas, privadas ou públicas que celebram contratos internacionais ${ }^{358}$.

Já Galgano e Marrella, por sua vez, classificam os atores do comércio internacional em Estados; organizações Internacionais, que incluem entes supranacionais, como União Européia, as organizações intergovernamentais como o Instituto Internacional para Unificação do Direito Privado (UNIDROIT) e outros organismos internacionais, como a Conferência das Nações Unidas sobre Comércio e Desenvolvimento (UNCTAD); e os atores não estatais, divididos, por sua vez, em ONGs e nas empresas multinacionais ${ }^{359}$.

Embora qualquer classificação dos atores possa ser passível de críticas, a sistematização adotada é baseada na proposta de GALGANO e MARRELLA, mas com alguns desvios, não necessariamente em razão da natureza do ator em questão, mas em razão da relevância. Além dos Estados, organizações e organismos internacionais, ongs e empresas transnacionais, serão abordados também as entidades profissionais de caráter coletivo e os prestadores de serviços jurídicos, especialmente os escritórios de advocacia, que exercem um papel fundamental para a lex mercatoria ${ }^{360}$.

\footnotetext{
${ }^{356}$ Y. DeZAlay; D. M. TRUBEK, A reestruturação global e o direito..., pp. 36-7. Os autores sustentam que o campo jurídico é um campo social, integrando uma sociedade com uma série de campos interrelacionados, semi-autônomos.

${ }^{357}$ F. OSMAN, Les principes généraux..., p. 457.

358 A. FRIGNANI, L'arbitrato commerciale internazionale..., p. 138.

${ }^{359}$ F. Galgano; F. MARRElla, Diritto del commercio internazionale, Padova, Cedam, 2005, pp. 17 e ss. Embora os autores utilizem empresas multinacionais, o termo mais apropriado seria transnacional, utilizado neste trabalho.

${ }^{360}$ Ressalte-se que os árbitros e também juízes internacionais produzem normas da nova lex mercatoria.
} 


\subsubsection{Estados}

Além das empresas transnacionais, os Estados, a partir do século XIX, passaram a representar importantes figuras comerciais, intervindo na economia, especialmente por monopólios em determinadas trocas e pela operação de ferrovias, navegação e serviços postais $^{361}$.

Os Estados, que outrora se mantinham afastados das atividades próprias e típicas da comunidade, restringindo-se à organização dos serviços públicos e à administração da coisa pública, adotaram progressivamente comportamento diverso, principalmente após a primeira e segunda guerra mundiais.

Desenvolveram, assim, caráter empreendedor, assumindo um novo papel no comércio internacional. Com o fim de atrair capitais estrangeiros e tecnologia estrangeira para seus propósitos de crescimento econômico, celebraram contratos de desenvolvimento, estimulando e incentivando a iniciativa privada ${ }^{362}$.

Outro importante fator para a constituição desse cenário foi o surgimento dos Estados socialistas e comunistas, que deram ainda maior relevância ao setor público na economia. Aos poucos, os State contracts passaram a incluir a cláusula compromissória, de modo que as controvérsias oriundas daquele contrato fossem dirimidas por arbitragem.

Nessas condições, a esfera de imunidade dos Estados foi progressivamente reduzida, principalmente com fundamento na teoria dos atos iure imperii e iure gestionis. Quando praticados atos desta natureza, o Estado se coloca na mesma condição da parte privada, de maneira tal que esta não ficasse em condições de inferioridade de direito ou de fato ${ }^{363}$.

\footnotetext{
${ }^{361}$ I. BROWNLIE, Principles of Public International Law, $5^{\text {a }}$ ed, Nova Iorque, Oxford, 1998, p. 327.

${ }^{362}$ J. C. DE MAGALHÃES, O Supremo Tribunal Federal e o Direito Internacional - Uma análise Crítica, $1^{\mathrm{a}}$ ed., Porto Alegre, Livraria do Advogado, 2000, p. 128.

${ }^{363}$ F. MARrella, La nuova lex mercatoria..., p. 133. I. BRownlie, Principles of Public, pp. 330 e ss., menciona que "after earlier doctrinal development Belgian and Italian courts responded to the extensions of state activity by developing a distinction between acts of government, jure imperii, and acts of a commercial nature, jure gestionis, denying immunity from jurisdiction in the latter case", discorrendo em seguida sobre os critérios para identificação da natureza do ato praticado pelo Estado segundo essa classificação.
} 


\subsubsection{Organizações internacionais e intergovernamentais}

As organizações internacionais, de vocação universal ou mesmo regional, também podem ser consideradas sujeitos da lex mercatoria, de duas formas.

Primeiro, quando figurarem como partes em contrato, na medida em que a elas se aplica também a doutrina que limita a imunidade jurídica na prática de atos ius gestionis $^{364}$.

Mas são também sujeitos do comércio internacional na medida em que podem estabelecer regulamentação e, de certa forma, moldar a estrutura do comércio internacional, como é o caso, por exemplo, da Organização Mundial do Comércio, de abrangência mundial, ou do Mercosul, de abrangência regional.

Além disso, outras organizações intergovernamentais também podem criar marcos e regras importantes para o comércio internacional. Sob os auspícios da Comissão das Nações Unidas para o Direito Comercial Internacional (UNCITRAL), por exemplo, foram elaboradas a Convenção de Nova Iorque sobre Reconhecimento de Laudos Arbitrais Estrangeiros, de 1958, hard law, ou a Lei Modelo de Arbitragem Comercial Internacional, de 1985, soft law ${ }^{365}$.

Da mesma maneira, também o Instituto Internacional para Unificação do Direito Privado (UNIDROIT), organização intergovernamental independente, com sede em Roma, Itália ${ }^{366}$, cujas atividades consistem, além da publicação da Revista de Direito Uniforme (Uniform Law Review), organização de seminários e conferências, dentre

\footnotetext{
${ }^{364}$ F. MARRELla, La nuova lex mercatoria..., p. 136.

365 Vide http://www.uncitral.org/uncitral/en/uncitral_texts.html para as demais realizações da UNCITRAL. Os termos hard law e soft law são utilizados em um sentido mais geral e relacionado a direito comercial internacional, para contrastar, respectivamente, instrumentos jurídicos vinculantes daqueles não vinculantes, cujo fundamento é a persuasão, na medida em que dependem de sua adoção pelas partes. Este sentido é adotado, e.g.., por M. J. BonELL, Unidroit Principles 2004 - The New Edition of International Commercial Contracts adopted by the International Institute for the Unification of Private Law, in Uniform Law Review, 2004, pp. 5-40 e A. S. HARTKAMP, Modernisation and Harmonisation of Contract Law -Objectives, Methods and Scope, in Uniform Law Review, 2003, pp. 8196. No direito internacional, o termo pode ter também um sentido distinto, que vai além da distinção entre vinculante e não vinculante, criando níveis e texturas diferentes de vinculação. Vide, por exemplo, R. R. BAXTER, International Law in "Her Infinite Variety", in International and Comparative Law Quarterly, v. 29, 1980, p. 549-566. M. DELMAS-MARTY, Les forces imaginantes du droit..., pp. 181-2, recorda que, em francês, o termo soft law (droit mou), cujo oposto é a hard law (droit mou), tem dois sentidos, um que poderia sugerir "que la faiblesse du droit ou sa suplesse si l'on veut rester neutre, peut affecter soit la force obligatoire (l'intensité des normes serait graduée entre dur et mou), soi la force contraignante (l'intensité des sanctions, entre dur et moux)". As 'externalidades' que se imputam à utilização da soft law serão abordadas nos itens 4.1.4 e 4.2.

${ }^{366}$ Foi originalmente criado em 1926 como um órgão auxiliar da Liga das Nações. Extinto com esta, foi reconstituído em 1940 por acordo multilateral (the UNIDROIT Statute), do qual foi signatário, e portanto um dos membros fundadores, o Brasil. Atualmente são 63 os Estados-membros do UNIDROIT, cf. disponível [on-line] in http://www.unidroit.org/english/members/main.htm [26-11-2009].
} 
outras atividades, na elaboração de convenções, leis-modelo, princípios gerais e guias legais.

As convenções de direito uniforme são a Convenção da Haia de 1964 relativa à Lei Uniforme sobre a Compra e Venda Internacional de Bens Móveis Corpóreos e Convenção da Haia de 1964 relativa à Lei Uniforme sobre a Formação dos Contratos de Compra e Venda Internacional de Mercadorias; Convenção de Bruxelas de 1970 relativa aos Contratos de Viagem; Convenção de Washington de 1973 relativa à Lei Uniforme sobre a Forma de um Testamento Internacional; Convenção de Genebra de 1983 sobre a Representação em Matéria de Venda Internacional de Mercadorias; Convenções do UNIDROIT de 1988 sobre Leasing Financeiro Internacional e sobre Factoring Internacional; Convenção do UNIDROIT de 1995 obre Bens Culturais Roubados ou Ilicitamente Exportados; Convenção de 2001 relativa às Garantias Internacionais referentes aos Equipamentos Móveis e seu Protocolos relativo às Questões Específicas dos Materiais dos Equipamentos Aeronáuticos e, mais recentemente o Protocolo de Luxemburgo de 2007 relativo às Questões Específicas dos Material Rolantes Aeronáuticos; e Convenção do UNIDROIT de 2009 sobre as Regras Materiais Relativas a Valores Mobiliários Intermediários.

O UNIDROIT adotou também a Lei Modelo sobre Divulgação de Informações em Matéria de Franquia, de 2002, e a Lei Modelo sobre Leasing, de 2008.

O Instituto elabora também os guias legais sobre novas técnicas empresariais, destinados aos profissionais com elas não familiarizados, como o Guia sobre Acordos Internacionais de Franquia Principal, de 1998 e com segunda edição de 2008.

São elaborados também sob seus auspícios os princípios gerais, soft law também, que têm como destinatários principais juízes, árbitros e partes de um contrato. Além da publicação, em conjunto com o American Law Institute, dos Princípios de Processo Civil Transnacional, o UNIDROIT publicou os Princípios para os Contratos Comerciais Internacionais, cuja primeira edição é de 1994, a segunda é de 2004 e uma terceira, em elaboração, está prevista para os próximos anos ${ }^{367}$.

A lista das organizações internacionais que influenciam a formação e desenvolvimento da nova lex mercatoria é longa, incluindo a Organização Internacional do Trabalho, a Organização de Aviação Civil Internacional, a Organização Mundial de

\footnotetext{
367 Vide item 3.5.1.1 a respeito do conteúdo e função dos Princípios UNIDROIT. Sobre o desenvolvimento do projeto da terceira edição, vide http://www.unidroit.org/english/workprogramme/study050/main.htm.
} 
Propriedade Intelectual, a Organização Mundial do Comércio, Banco Mundial, Fundo Monetário Internacional, entre outros ${ }^{368}$.

\subsubsection{Empresas transnacionais}

Embora por vezes referida como 'empresas multinacionais', a expressão não é a mais adequada para refletir o papel e a organização dos grandes grupos empresariais na sociedade pós-industrial.

O termo multinacional, que é fundado na idéia de nações, não é suficiente, na medida em que eram manifestações preliminares de sua capacidade de se desvincular de um território estatal. Mas, o crescimento da mobilidade do capital, e também das novas tecnologias, intensificou o processo, tornando essas empresas transnacionais ${ }^{369}$. Entretanto, a expressão faz referência não apenas a uma das sociedades, estabelecidas em um determinado Estado e, portanto, de direito interno, mas ao grupo multi- ou transnacional de empresas ${ }^{370}$.

No século $\mathrm{XX}$, os grandes grupos empresariais passaram a separar a administração estratégica e financeira da empresa das operações em si, com grande mobilidade do capital industrial. Assim, as holdings passaram a ter grande relevância, dirigindo as empresas controladas, que localizadas, muitas vezes, em outros países e continentes $^{371}$, são o instrumento utilizado para concretizar a transnacionalidade das empresas.

Interessante notar, como reflexo desse fenômeno, que, segundo estimativas, entre um quarto e um terço de todo o comércio mundial é feito entre empresas do

\footnotetext{
${ }^{368}$ Vide F. Galgano; F. MARrella, Diritto del commercio internazionale ..., pp. 29-62 e ss.

${ }^{369}$ M. R. FERRARESE, Il diritto al presente..., p.167.

${ }^{370}$ F. Galgano; F. MARRElla, Diritto del commercio internazionale..., pp. 71 e 88.

${ }^{371}$ F. GALGANO, La globalizzazione..., pp. 21-2, para quem a "holding si rivela una figura suscettibile di assumere una duplice e ben differenziata collocazione: a volte si presenta come un soggetto dell'economia industriale (são as holdings industrais), e anzi ne è la principale protagonista; altre volte si presta ad essere collocata in tutt'altro ambito, quale soggeto dell'economia finanziaria, del terziario avanzato". Complementa (p. 24), após dar o exemplo (p. 23) de uma holding financeira de uma montadora de automóveis, explicando que não a produção de veículos e vendas dependem diretamente da capacidade e decisões de investimento da holding, que as atividades das holdings e das controladas são extremamente complementares entre elas e que nenhuma das controladas pode, de forma realmente autônoma, decidir sua própria política. Para uma descrição mais detalhada dos grupos empresariais e das holdings, principalmente da perspectiva do direito italiano, vide F. GALGANO; F. MARRELlA, Diritto del commercio internazionale..., pp. 87-123.
} 
mesmo grupo ${ }^{372}$, o que constitui um importante desafio ao controle de parcela significativa do comércio internacional.

Segundo um relatório da UNCTAD, com base em dados de 2007, entre as 100 maiores não-financeiras do mundo, quase $85 \%$ tem um índice de transnacionalidade maior do que $50 \%$ (várias com índice superior a $80 \%$, e uma delas - uma mineradora inglesa - tem 94.1\%). Além disso, quase metade das empresas que têm índice abaixo de $50 \%$ estão entre as 40 maiores empresas ${ }^{373}$. Esses dados, por si, já demonstram a capacidade das empresas atuarem - principalmente por intermédio das holdings - além das fronteiras de seus países e a razão de denominá-las de empresas transnacionais ${ }^{374}$.

As empresas transnacionais exercem papel central na economia atual, sendo as instituições privadas dominantes, com forte influência no consumo e, de certa forma, na cultura, determinando rumos sobre estilo de vida, identidade, moda, e também, direta ou indiretamente, na política, principalmente por meio de lobbies $^{375}$. Basta notar que a economia interna de alguns grupos econômicos é maior do que o produto interno bruto de muitos países ${ }^{376}$.

Para FERRARESE, "la globalizzazione rappresenta un enorme processo di istituzionalizzazione del mercato su scala mondiale. Ciò significa una super-istituzione transnazionale, che attraversa le diversità culturali, economiche, religiose, giuridiche, ecc., combinandosi in modi vari con essi" ${ }^{\prime 377}$.

\footnotetext{
372 F. Galgano, La globalizzazione..., p. 27. A. C. Cutler, Private Power ..., p. 202 adverte que a proliferação de relações entre empresas do mesmo grupo desafia a própria identidade das empresas e, portanto, indiretamente minam a autoridade dos Estados. O fenômeno se agrava à luz da utilização das holdings e do law shopping e o forum shopping. Vide F. GALGANO, La globalizzazione ..., pp. 83 e ss. e 157 e ss., E. LoQuin, Où en est la lex mercatoria..., p. 43 e M. R. FerRARESE, Le istituzioni della globalizzazione..., pp. 42 e ss.

373 Transnational Index (TNI) calculado pela média das seguintes três razões: patrimônio no exterior/patrimônio total; vendas no exterior/total de vendas e empregados no exterior/total empregados. Vide http://www.unctad.org/sections/dite_dir/docs/wir2009top100_en.pdf. O World Investment Report da UNCTAD de 2009 apurou que o nível de transnacionalidade, diferentemente do que ocorreu entre 2006 e 2007, não aumentou de 2008 para 2009, principalmente em razão da crise. Vide http://www.unctad.org/en/docs/wir2009_en.pdf.

${ }^{374}$ F. Galgano, La globalizzazione..., p. 27. A. C. Cutler, Private Power ..., p. 201 lembra que, em razão mesmo dessa capacidade de se transnacionalizar, há uma questão significativa de normativo e de responsabilidade das empresas, até porque não há como garantir a nacionalidade dessas empresas. A autora (pp. 202-3) observa que a "...emphasis on the legal aspects of the corporate personality risks a formalism that mistakes the legal form for the actual conduct and practices of corporations and of states. It also risks obscuring how corporations use their nationality to avoid or evade responsibility". De qualquer modo, a questão será analisada no item 4.2.

${ }^{375}$ A. C. CutLer, Private Power ..., p. 21 e M. R. Ferrarese, Le istituzioni della globalizzazione..., pp. 113-4.

${ }^{376}$ F. MARRELLA, La nuova lex mercatoria tra controversie..., p. 252, com base no World Investment Report 2004 da UNCTAD.

${ }^{377}$ M. R. FERRARESE, Le istituzioni della globalizzazione..., pp. 113-4.
} 
As empresas transnacionais nem sempre exercem um papel jurídico, delegandoo aos escritórios de advocacia ${ }^{378}$. As empresas podem, no entanto, desenvolver funções jurídicas com seus contratos-padrão ou condições gerais destinados a regular todas as suas relações com clientes ou fornecedores. Embora tenham influência na cultura jurídica e sejam difundidos por meio das holdings e também do comércio entre empresas do mesmo grupo, esses contratos-padrão ou condições gerais, segundo FRIGNANI, não constituem usos comerciais ao menos até que se demonstre que "la stragrande maggioranza delle imprese del settore adottano clausole uguali",379.

\subsubsection{Entidades profissionais}

Como já observado ${ }^{380}$, as entidades profissionais são um dos fatores fundamentais do aparecimento e desenvolvimento da nova lex mercatoria. GOLDMAN, em seu clássico texto, menciona que no século XIX, em que se viu o renascimento dos usos profissionais comuns da venda internacional, a London Corn Trade Association criada em 1877 e reformulada em 1886 - criou e deixou à disposição dos operadores os contratos-tipo, que proveriam o comércio de cereais de "uniformidade de suas transações, favorecendo a adoção de usos fundados sobre princípios justos e equinânimes" 381 .

As entidades profissionais têm, assim, papel fundamental na difusão dos usos por meio de práticas contratuais repetidas pela classe mercantil. Essas entidades assumem, também, verdadeiro papel institucional ${ }^{382}$.

Mas, além dos contratos-tipo, as entidades profissionais, como também já observado, têm centros de arbitragem próprios, que, além de consolidar e difundir práticas e usos, podem enunciar regras aplicáveis a casos futuros. A relevância das

\footnotetext{
${ }^{378}$ M. R. Ferrarese, Le istituzioni della globalizzazione..., pp. 119. A autora acrescenta também que o papel do jurista da empresa seria diferente daquele das law firms, já que este manteria independência, aquele não - o que a nosso ver, na prática, nem sempre é verdadeiro.

379 A. FrIGNANI, L'arbitrato commerciale internazionale..., p. 153. Vide P. T. MUCHLINSKI, Global Burkowina Examined - Viewing the Multinational Enterprise as a Transnational Law-Making Community, in TEUBNER, Gunther (org.), Global Law Without a State, Burlington, Ashgate, 2006, pp. 94 e ss.

${ }^{380}$ Vide item 3.2.4.

${ }^{381}$ B. Goldman, Frontières..., p. 179. A discussão sobre se, efetivamente, os contratos-tipo de entidades profissionais dessa natureza são fundados ou levam a negócios mais justos e eqüinânimes foge do escopo deste trabalho, na medida em que dependeria de uma análise, caso a caso, desses instrumentos.

${ }^{382}$ Segundo W. KONRADI; H. FIX-FIERRO, Lex mercatoria in the mirror..., pp. 222-3, "legal sociology should primarily focus on the processes of norm creation, the mechanism for the stabilization of expectations within particular social systems, as well as on the structural consequences of this type of self-regulation for both global law and national law”. Sobre a noção de institucionalização, vide n.r. 153.
} 
regras enunciadas pelos tribunais arbitrais formados sob os auspícios dessas entidades profissionais tende a ser maior naquele setor econômico específico ${ }^{383}$, podendo constituir uma lex mercatoria setorial em cada um desses ramos ${ }^{384}$.

As entidades profissionais exercem outra função institucional na nova lex mercatoria: aplicar sanções. Ao lado das sanções aplicadas por meio dos Estados, quando os laudos arbitrais forem executados pelos tribunais estatais, as sanções de cunho moral (publicação do descumprimento, por exemplo) e/ou econômico (multa, por exemplo) são implementadas por meio dessas entidades ${ }^{385}$.

Além disso, as entidades profissionais são elemento constitutivo da societas mercatorum $^{386}$. Formam uma espécie de centro de coesão de interesses da classe mercantil, sendo um instrumento ou canal valioso para a representação dos interesses das empresas transnacionais e diálogo com os demais atores da nova lex mercatoria.

É comum associações dessa natureza em mercados de commodities. A título exemplificativo apenas, há as já mencionadas Liverpoool Cotton Exchange, London Stock Exchange e London Corn Trade Exchange e Coffee Trade Association, New York Stock, Produce, Mercantile, Cotton, and Coffee and Sugar Exchanges, Chicago Board of Trade, St. Louis Merchants' Exchange, Philadelphia Commercial Exchange, Kansas City Board of Trade, Milwaukee Grain Exchange. Grain and Feed Dealers Association, National Hay Association, the National Cotton Seed Products Association, the American Seed Trade Association ${ }^{387}$, London Corn Trade Association, Fosfa, Gasfa, Rucip, International Wool Textile Organization.

\subsubsection{Outras organizações não governamentais}

A sociedade civil, sob a forma de organizações não-governamentais (ONGs) de vocação econômica transnacional são também sujeitos da nova lex mercatoria. Ressalte-se que as ONGs não têm personalidade jurídica internacional, sendo associações regidas pelo direito interno ${ }^{388}$.

\footnotetext{
${ }^{383}$ Nada impede que as regras enunciadas ultrapassem o círculo de uma determinada indústria e alcance ares mais gerais.

${ }^{384}$ Vide item 3.6 abaixo.

385 A efetividade e as sanções da lex mercatoria são pontos controvertidos, suscitando críticas sobre a caracterização ou não da nova lex mercatoria como ordenamento jurídico e/ou de suas regras como jurídicas. Vide item 4.1.3.2.

${ }_{386}$ Vide item 4.1.3.3.

${ }^{387}$ A. C. CUTLER, Private Power ..., pp. 175 e ss.

${ }^{388}$ F. MARRELLA, La nuova lex mercatoria..., p. 140.
} 
As ONGs atuam tanto na elaboração do direito quanto no controle de sua aplicação, razão pela qual - nesta perspectiva - aproximam-se de tornar-se sujeitos também políticos. Representam outros atores que não o Estado, tutelando o interesse coletivo da sociedade civil transnacional, de modo que a distinção entre público e privado se torne cada vez menos nítida e a ordem pública se desnacionalize, ou melhor, transnacionalize ${ }^{389}$.

AS ONGs podem representar interesses tanto econômicos, quanto não econômicos. As primeiras assumem as mesmas funções que as entidades profissionais mencionadas acima, com a diferença de que sua atuação tem caráter geral, seja por não representar uma indústria especifica, seja por não representar um país ou território específico.

Enquadram-se nesta categoria, a título exemplificativo, a Câmara de Comércio Internacional (CCI), o Comité Maritime International (CMI), International Airport Association (IATA), International Accounting Standard Board (IASB), International Shipping Federation (ISF), International Pilots Association (IMPA), International Association of Independent Tank Owners (INTERTANKO); Féderation Internationale des Ingénieurs-Conseils (FIDIC), International Standard Organisation (ISO).

Já as outras ONGs podem constituir um importante contraponto aos efeitos negativos da globalização, devendo ser a plataforma de construção de diálogo para consecução de equilíbrio entre a nova lex mercatoria e os direitos humanos e do meioambiente, por exemplo.

\subsubsection{Prestadores de serviços jurídicos}

Os prestadores de serviços jurídicos exercem papel fundamental na criação da nova lex mercatoria, como também na sua comunicação, difusão, circulação, em um mercado que é mais um não lugar do que propriamente um lugar ${ }^{390}$. Embora haja outras formas de prestação de serviços jurídicos ou serviços relacionados relevantes, a análise do papel dos escritórios de advocacia permitirá estender, na medida cabível, aos demais prestadores de serviços jurídicos ${ }^{391}$.

\footnotetext{
${ }^{389}$ M. R. FERRARESE, Le istituzioni della globalizzazione..., p. 108-10.

${ }^{390}$ M. R. FERRARESE, Le istituzioni della globalizzazione..., p. 107.

${ }^{391}$ Podem ser equiparados também as grandes auditorias contábeis. M. R. FERRARESE, Le istituzioni della globalizzazione..., pp. 92-3.
} 
Assim como a inovação tecnológica, a inovação jurídica também é fator de competitivade e concorrência ${ }^{392}$. Segundo FERRARESE, "non si tratta di un ruolo di mero supporto economico...”, mas “...della costruzioni di nuovi percorsi di legalità che sono strettamente intrecciati con la vita e vicende delle imprese", na medida em que trabalham "...non solo per le imprese, ma anche a stretto contatto con la vita delle emprese; esse possono funzionare sia come convertitrici di dinamiche economiche in dinamiche giuridiche, sia come convertitrici di schemi giuridici in dinamiche economiche",393.

Em uma sociedade em que cada vez mais a distinção entre público e privado se torna menos nítida, as law firms criam pontos de encontro entre público e privado, atuando, por exemplo, na criação do direito (law making), planejamento tributário e, por vezes, fazendo lobby $y^{394}$.

Como já observado, um dos principais elementos de desenvolvimento da nova lex mercatoria é a circulação de usos, principalmente por meio de modelos contratuais uniformes, usualmente contratos atípicos, ou seja, medidas jurídicas novas, criativas e sob medida. Não são os legisladores nacionais que realizam tal tarefa, mas os advogados ${ }^{395}$. Em razão disso, FERRARESE aponta que "la cosiddetta lex mercatoria non è più, in tal senso, un corpo di misure giuridiche elaborata dalla tradizione del mondo commerciale e che esprime usi e consuetudini; diventano anzi piuttosto il suo contrario, ossia un universo normativo estremamente mobile, soggetto a continue manipulazioni e ritocchi che sono paralleli alla estrema mobilità del mercato"396.

DEZALAY e TRUBEK observam que o modo de produção do direito inclui, além da localização de papéis entre as várias posições no campo jurídico, relação entre

\footnotetext{
${ }^{392}$ M. R. FERRARESE, Le istituzioni della globalizzazione..., p. 95.

${ }^{393}$ M. R. FERRARESE, Le istituzioni della globalizzazione..., pp. 92-3 e Il diritto al presente..., p. 83.

${ }^{394}$ M. R. FERRARESE, Le istituzioni della globalizzazione..., pp. 92-3 e 136. Os lobbies certamente trazem algumas dificuldades do ponto de vista da legitimação das normas ou regras promulgadas ou criadas por sua influência, direta ou indireta. De maneira geral, o desafio da legitimidade e representação democrática será tratado no item 4.1.4 e 4.2. Embora os advogados criem novos percursos de legalidade e pontos de encontro entre o público e o privado, são os árbitros ou juízes que estabelecem a relação entre privado e público, local e global.

${ }^{395}$ F. GAlGANo, La globalizzazione ..., p. 94. M. R. FERRARESE, Il diritto al presente..., p.83, observa que "le grandi law firms transnazionali... hanno uno stile di lavoro eminentemente creativo anziché esegetico: la loro funzione non è tanto quella di interpretare un diritto considerato prescrittivo, quanto quella di contribuire a creare e adattare nuovi strumenti giuridici rispetto alle ossobilità ed ai bisogni di scambio".

${ }^{396}$ M. R. FERRARESE, Le istituzioni della globalizzazione..., p. 50. A autora complementa que o direito tende a se tornar mímese às necessidades do mercado e impõe um desafio à calculabilidade e certeza. $\mathrm{O}$ direito anglo-saxão é menos afetado do que o direito continental, de tradição romano-germânica, em razão de o primeiro ser um direito judicial. Vide n.r. 231.
} 
regulamentação e proteção, modo com que a profissão jurídica e a prestação de seus serviços são organizadas ${ }^{397}$.

O direito transnacional na sociedade pós-industrial também pode ser analisado sob a perspectiva de um modo particular de produção do direito, que emergiu primeiro nos Estados Unidos, se expandiu para Europa e exerce influência em todo o mundo ${ }^{398}$. DEZALAY e TRUBEK ressaltam que "o claro contraste entre... o modo americano de produção do direito e o sistema europeu reside na organização da prestação dos serviços jurídicos aos negócios...". O modelo americano "apresenta tanto características únicas como gerais da cultura jurídica norte-americana e tem um impacto que transcende o reino do direito econômico. Deste modo, a grande empresa de advogados é não só emblema como a máquina de todo o campo jurídico norte-americano"399.

O modo estadunidense de produção do direito é mais propenso a acompanhar as necessidades do direito transnacional, em razão da centralidade do papel dos advogados. Como conseqüência, "a relação entre hierarquia social e o campo jurídico é mais direta e aberta nos Estados Unidos do que tem sido na Europa Continental"400.

Ao contrário, segundo Dezalay e TrubeK, o campo jurídico europeu não se mostrou adequado às exigências da sociedade pós-industrial, ao passo que "... as firmas corporativas americanas possuem o exato tipo de organização, 'know-how' e tecnologia necessários para atender estas demandas... As grandes firmas corporativas americanas juntaram-se às Seis Grandes Firmas Contábeis ${ }^{401}$... Das firmas contábeis foi tomada a idéia de uma forte integração das práticas contábeis, econômicas e jurídicas (pluridiscipliariedade) e uma tradição empresarial ainda mais forte do que a das firmas americanas de serviços jurídicos”. As firmas européias criadas a partir dessas influências "mesclaram elementos retirados do antigo modelo europeu, incluindo a

\footnotetext{
${ }^{397}$ Entre outros aspectos, cf. Y. DEZAlay; D. M. TRUBEK, A reestruturação global e o direito... pp. 3940.

${ }^{398}$ Entre outros aspectos, cf. Y. DEZALAY; D. M. TRUBEK, A reestruturação global e o direito... p. 40.

399 Y. DeZAlay; D. M. TRUBEK, A reestruturação global e o direito... pp. 42-44. Os autores destacam ainda a influência direta e substancial que as law firms tem nas faculdades de direito.

${ }^{400}$ Y. DeZAlay; D. M. TRUBEK, A reestruturação global e o direito... pp. 46-7. Os autores apontam que “... a profissão jurídica nos Estados Unidos, mais do que qualquer outra, tem adotado a idéia do equilíbrio de forças jurídicas, dispondo de serviços jurídicos para os pobres, impondo um dever geral de serviço 'pro-bono' e adotando uma exclusiva 'empresa de defesa do interesse público' norte-americana. Estas formas de legitimação através de reformas neutras e do equilíbrio de forças encontram-se num forte contraste com o tradicional sistema europeu".

${ }^{401}$ Entre 1989 e 1998 as seis grandes firmas de auditoria eram Arthur Andersen, Coopers \& Lybrand, Ernst \& Young, Deloitte \& Touche, Peat Marwick Mitchell, Price Waterhouse. Em 1998, Price Waterhouse e Coopers \& Lybrand formaram a PricewaterhouseCoopers. Desde 2002, a Arthur Andersen, em razão do escândo Enron, foi absorvida pela Ernst \& Young, globalmente, Deloitte \& Touche no Reino Unido e Canadá e por PricewaterhouseCoopers na China e Hong Kong.
} 
proximidade de contato com acadêmicos de alto nível ou juristas 'notáveis', bem como o recrutamento de advogados cosmopolitas provindos das elites. Estes desdobramentos levaram à criação de um tipo híbrido de firma jurídica corporativa européia, que em alguns casos pode estar ainda melhor adaptada a um mercado de direito europeu do que as firmas de serviços jurídicos e contábeis americanas" ${ }^{\text {402 }}$.

\section{4. Âmbito de aplicação}

A lex mercatoria tem por conteúdo regras que são direito comercial internacional. Adverte GALGANO que "il diritto commerciale non é il diritto del commercio: non regola ne mai ha regolato, tutto il commercio; non é mai stato un sistema normativo auto-sufficiente, ordinante un intero settore della vita economica"403.

Assim, o primeiro e importante aspecto a destacar é que a lex mercatoria não só não regula todo o direito do comércio, como também seu conteúdo não compreende determinadas matérias que ficam a cargo dos demais ordenamentos jurídicos com os quais têm relação complementar e não alternativa. MARRELLA, por exemplo, recorda que a nova lex mercatoria não se aplica a questões falimentares ${ }^{404}$. OSMAN observa que a lex mercatoria não regula a totalidade das relações jurídicas que podem afetar a societas mercatorum, sendo excluídas, por exemplo, questões como capacidade das partes e responsabilidade por delitos ${ }^{405}$.

Em seu texto pioneiro sobre a nova lex mercatoria, GOLDMAN define comércio internacional como o conjunto das relações econômicas, aí incluídas as relações internacionais de troca de que participam ao menos uma empresa privada ou uma empresa pública não se utilizando de prerrogativas próprias aos Estados. A venda e compra, tradicionalmente, é a operação primeira nessas relações, apoiada pelos contratos de transporte e de crédito documentário ${ }^{406}$.

\footnotetext{
${ }^{402}$ Y. DeZAlay; D. M. TRUBEK, A reestruturação global e o direito... pp. 48-9.

${ }^{403}$ F. GALGANO, Lex mercatoria..., p. 10.

${ }^{404}$ F. MARRELLA, La nuova lex mercatoria tra controversie..., p. 250. As relações da lex mercatoria são principalmente em relação ao Estado. Por exemplo, questões como capacidade das partes continuam a ser reguladas pelo direito estatal. A relação entre a lex mercatoria e os demais ordenamentos jurídicos é analisada no item 4.2.

${ }^{405}$ F. OSMAN, Les principes généraux..., p. 456.

${ }^{406}$ B. Goldman, Frontières..., p. 177. Como salienta F. MARRELla, La nuova lex mercatoria..., p 153, "il contratto di compra e vendita..., da sempre, contistuisce il cuore del commercio ed è proprio di quel contratto che sono fiorite molte delle riflessione sulla nuova lex mercatoria".
} 
Os contratos internacionais, por função exercida, podem ser distinguidos em contratos para circulação de bens, entre os quais figura a compra e venda; contratos para realização ou promoção de negócios, tais como os contratos de representação comercial e os de distribuição; os contratos de transporte das mercadorias; os contratos financeiros e os instrumentos de pagamento; os contratos de seguro; os contratos de prestação de seguro; os contratos de circulação de tecnologia, como contratos de transferência de tecnologia; os contratos associativos entre empresas; os contratos ou instrumentos de garantia; e os contratos de investimento ${ }^{407}$.

FERRARESE recorda que a lex mercatoria composta, em grande parte, além de usos comerciais e decisões arbitrais, de módulos contratuais atípicos, que são principalmente os contratos em ing, tais como leasing, factoring, franchising (franquia), marketing, entre outros, obra principalmente dos grandes escritórios de advocacia dos Estados Unidos ${ }^{408}$.

Essas espécies contratuais, instrumentos pelos quais opera a nova lex mercatoria, enquadram-se no gênero dos contratos comerciais internacionais. Importa, assim, analisar o que caracteriza um contrato como internacional e como comercial, pois a lex mercatoria se aplica a esses contratos ${ }^{409}$.

No que concerne à internacionalidade, ao longo do século XX diversos foram os critérios propostos para que assim se pudesse caracterizar um contrato.

Um dos critérios que exerceu grande influência é aquele do Procurador-Geral francês Matter. Essa abordagem é essencialmente econômica e se caracteriza pela "transferência internacional, ou seja, movimento de fluxo e refluxo de divisas, ultrapassando fronteiras nacionais" ${ }^{, 410}$.

A Cour de Cassation, na década de 30, define que "contrato internacional é aquele que 'põe em jogo os interesses do comércio internacional'"411.

Em relação aos critérios jurídicos, observa STRENGER que os elementos referentes à "localização geográfica dos bens, das pessoas ou operações materiais"

\footnotetext{
${ }^{407}$ F. GALGANO; F. MARRELlA, Diritto del commercio internazionale....

${ }^{408}$ M. R. FERRARESE, La lex mercatoria tra storia e attualità - da diritto dei mercanti a lex per tutti?, in Sociologia del Diritto, v. 32, n. 2-3, 2005, p. 162.

409 A delimitação do âmbito de aplicação da nova lex mercatoria é importante a fím de clarear algumas críticas feitas, principalmente em momentos de crises econômicas. Vide item 4.2.

${ }^{410}$ I. STRENGER, Contratos Internacionais do Comércio, 3a ed., São Paulo, LTr, 1998, p. 73.

${ }^{411}$ I. STRENGER, Contratos Internacionais...., p. 74.
} 
exerce papel preponderante. Assim, passa-se a considerar o domicílio, sede social dos contratantes, nacionalidade e outros elementos de conexão territoriais ${ }^{412}$.

Não há critério unívoco para a caracterização de um contrato como internacional, adotando-se o mais amplo possível. Assim, não se deve optar pelo critério econômico ou jurídico. Basta a "presença de um elemento de estraneidade que o ligue a dois ou mais ordenamentos jurídicos"413, seja o fluxo de valores entre Estados, domicílio em territórios distintos ou transporte internacional de mercadoria.

O critério de internacionalidade exposto acima é confirmado pelos Princípios UNIDROIT, expressão da nova lex mercatoria ${ }^{414}$.

Com efeito, o Preâmbulo dos Princípios UNIDROIT delimita sua aplicação aos contratos comerciais internacionais, presumindo que ao atributo internacional "should be given the broadest possible interpretation, so as ultimately to exclude only those situations where no international element at all is involved, i.e. where all the relevant elements of the contract in question are connected with one country only" 415.

Destaque-se, porém, que apenas nacionalidades distintas, quando as partes tiverem domicílio no mesmo país não deve ser considerado como elemento de estraneidade para fins de caracterização de um contrato como internacional. Ressalte-se, porém, que as partes de um determinado contrato não são necessariamente definidas pela sua sede ou por sua matriz, mas sim pelo domicílio da sociedade que tiver relação mais próxima com o contrato, que o tiver negociado ${ }^{416}$.

\footnotetext{
${ }^{412}$ I. STRENGER, Contratos Internacionais...., pp. 30 e 78.

${ }^{413}$ N. de. ARAúJo, Direito Internacional Privado - Teoria e Prática Brasileira, Rio de Janeiro, Renovar, 2003. p. 312. Vide I. STRENGER, Contratos Internacionais...., pp. 25 e ss. a respeito da noção de contrato internacional e maiores referências quanto aos critérios para caracterização de um contrato como internacional. Para esse autor (p. 73), "o contrato é internacional quando houver algum elemento de estraneidade" (p. 79), critério que parece ser o mesmo de H. Batiffol. STRENGER (p. 84) afirma, então, que "são contratos internacionais do comércio todas as manifestações bi ou plurilaterais da vontade livre das partes, objetivando relações patrimoniais ou de serviços, cujos elementos sejam vinculantes de dois ou mais sistemas jurídicos extraterritoriais, pela força do domicílio, nacionalidade, sede principal dos negócios, lugar do contrato, lugar da execução, ou qualquer circunstância que exprima um liame indicativo de Direito aplicável".

${ }^{414}$ Vide item 3.5.1.1.

415 Não obstante, é a priori possível a aplicação dos Princípios também aos contratos domésticos entre partes privadas, sendo neste caso naturalmente aplicáveis todas as normas de ordem pública. Vide Comentário 3 ao Preâmbulo dos Princípios UNIDROIT 2004, cf. disponível [on-line] http://www.unidroit.org/english/principles/contracts/principles2004/integralversionprinciples2004-e.pdf [15.12.2009].

${ }^{416}$ O artigo 10(a) da Convenção de Viena sobre a Compra e Venda Internacional de Mercadorias (CISG), de 1980, estabelece que "for the purposes of this Convention: (a) if a party has more than one place of business, the place of business is that which has the closest relationship to the contract and its performance, having regard to the circumstances known to or contemplated by the parties at any time before or at the conclusion of the contract;..."
} 
Por sua vez, a questão da comercialidade dos contratos internacionais passa necessariamente pela identificação de quem são os sujeitos privados da nova lex mercatoria, como feito no item 3.3 acima.

Salienta MARRELla que "sul piano del commercio internazionale, la categoria dell'imprenditore vigente nel diritto interno dei paesi del sistema romano-germanico appare superata. Sembra prevalere, invece, una nozione di merchant affine a quella conosciuta dalla Common Law, in particolare attraverso lo Uniform Comercial Code statunitense, ove non si definisce ciò che si intende per 'contratti commerciali' ma si escludono dallo UCC i contratti conclusi con i consumatori e la menzione del termine merchant, per quanto vaga, vale a delimitare il campo di applicazione di poche norme a seconda che una delle parti agisca come acquirente occasionale o come operatore economico agente nell'esercizio della propria attività professionale. Una prova tangibile del superamento della nozione statale dell'imprenditore in un contesto internazionaleregionale viene offerta in misura crescente dalla Corte di Giustiza Europea che, dinanzi alla Babele del diritto interno degli Stati Membri, ha dovuto progressivamente forgiare una nozione communitaria dell'imprenditore fondata su di un criterio economico che non coincide ne con il commerçant, ne con l'imprenditore (seppure molte siano le affinità proprio con la nozione italiana), ne con il comerciante spagnolo ne con il beddriff olandese e, tantomeno, con la nozione tedesca di kaufleute in tutte le sue variante...."417.

Ainda de acordo com MARrella, se passa de uma noção positiva de comerciante ou de atos de comércio para uma definição negativa, isto é, estão excluídos os contratos celebrados com consumidores ${ }^{418}$. Ou seja, a lex mercatoria aplica-se somente aos contratos business to business ${ }^{419}$.

Os Princípios UNIDROIT também confirmam tal perspectiva, já que não há definição nos Princípios UNIDROIT quanto ao tema, mas apenas a presunção de que “...the concept of 'commercial contracts' should be understood in the broadest possible sense, so as to include not only trade transactions for supply or exchange of goods, but

\footnotetext{
${ }^{417}$ F. MARRELLA, La nuova lex mercatoria..., pp. 129-30.

${ }^{418}$ F. MARRELLA, La nuova lex mercatoria..., p. 130.

${ }^{419}$ F. MARRELLA, La nuova lex mercatoria tra controversie..., p. 250.
} 
also other types of economic transactions, such as investment and/or concession agreements, contracts for professional services, etc. ${ }^{420}$.

Assim, "l'idea è piuttosto quella di escludere dall'ambito di applicazione dei Principi UNIDROIT i cosidetti contratti con i consumatori ('consumer transactions'), ossia quei contratti in cui una delle parti non agisce nell'ambito della propria attività commerciale o comunque nell essercizio della propria professione" ${ }^{\mathrm{4} 21}$.

A noção é a mesma daquela contida na CISG, que exclui da sua esfera de aplicação os contratos de compra e venda que tenham por objeto bens adquiridos para uso pessoal, familiar ou doméstico.

\subsection{Fontes}

Embora não haja, em geral, dissenso quanto aos instrumentos que criam regras de direito pertencentes à nova lex mercatoria, sua sistematização freqüentemente costuma apresentar algumas diferenças. Em geral, a presença de princípios gerais e de decisões arbitrais não costuma ter objeções, mas por vezes os contratos-tipo ou padrão e as cláusulas gerais são tratados como fonte adicional da lex mercatoria.

FERRARESE, por exemplo, sustenta que lex mercatoria composta, em grande parte, de módulos contratuais atípicos ou contratos-tipo, usos comerciais e decisões $\operatorname{arbitrais}^{422}$. Já para BosCHIERO seriam o contrato, os usos e as decisões arbitrais que fazem referência aos princípios gerais de direito comercial ${ }^{423}$. Segundo GALGANO, seriam a difusão internacional das práticas contratuais comerciais, os usos comerciais e na jurisprudência arbitral ${ }^{424}$. PANNARALE, por sua vez, classifica as fontes em princípios gerais de direito, novos institutos e cláusulas contratuais de contratos já existentes no direito interno, novos tipos de contrato da prática comercial internacional e jurisprudência arbitral ${ }^{425}$.

Segundo LANDO, as fontes da nova lex mercatoria seriam o direito internacional público, as leis uniformes, os princípios gerais, as regras das organizações

\footnotetext{
420 Comentário 2 ao Preâmbulo dos Princípios UNIDROIT 2004, cf. disponível [on-line] http://www.unidroit.org/english/principles/contracts/principles2004/integralversionprinciples2004-e.pdf [15.12.2009].

${ }^{421}$ M. J. BONELL, Un "codice” internazionale ..., p. 76.

${ }^{422}$ M. R. FERRARESE, La lex mercatoria..., pp. 160-1.

${ }^{423} \mathrm{~N}$. BosChIERO, La lex mercatoria nell'era della globalizzazione - considerazioni di diritto internazionale pubblico e privato, in Sociologia del Diritto, v. 32, n. 2-3, 2005, p. 85.

${ }^{424}$ F. GALGANO, La globalizzazione ..., pp. 58-9.

${ }^{425}$ L. PANnARALE, Delocalizzazione del diritto..., pp. 315-6.
} 
internacionais, os usos e costumes, os contratos-tipo (standard form contracts ) e os laudos arbitrais ${ }^{426}$.

A classificação das fontes mais adequada é a de $\operatorname{VIRALLY}^{427}$, FrignANi ${ }^{428}$ e OSMAN $^{429}$, segundo a qual são fontes da nova lex mercatoria os princípios gerais de direito, usos e, finalmente, as regras estabelecidas pela jurisprudência arbitral ${ }^{430}$.

Antes de tratar especificamente de cada uma dessas fontes, é importante ressaltar que não há restrições em relação à origem de seu conteúdo. Não é porque a lex mercatoria é um corpo de regras desterritorializado ou desnacionalizado - no sentido de que não está atrelada a um território específico e não porque se desenvolve fora de qualquer Estado - que suas regras não podem ser provenientes de um determinado ordenamento jurídico nacional, como por exemplo o duty to mitigate, originariamente de common $l a w^{431}$. Mas, mais do que isso, refletindo a dicotomia formalidadeinformalidade característica do direito na sociedade pós-industrial, seu conteúdo pode advir de direito ou fonte nacional, internacional ou transnacional.

\subsubsection{Princípios gerais}

A análise dos princípios gerais como fonte da nova lex mercatoria suscita algumas questões, especialmente (i) o que são esses princípios gerais e sua relação ; (ii) os requisitos para que enunciados jurídicos se tornem princípios gerais; (iii) qual a sua função em relação à nova lex mercatoria; (iv) se existem princípios específicos da nova lex mercatoria; e (v) quais são esses princípios.

Os princípios da nova lex mercatoria são, segundo o laudo CCI 3896/1982, "principes que sont à la base de toute relation contractuelle, notamment dans les

\footnotetext{
426 O. LANDO, The Lex Mercatoria In International Commercial Arbitration, in International and Comparative Law Quarterly, v. 4, n. 34, 1985, pp. 749 e ss.

${ }^{427}$ M. VIRALLY, Un tiers droit?..., p. 384.

${ }^{428}$ A. FRIGNANI, L'arbitrato commerciale internazionale..., p. 139.

${ }^{429}$ F. OSMAN, Les príncipes généraux..., p. 18.

${ }^{430}$ Essa sistematização das fontes da nova lex mercatoria é similar àquela das fontes do ius mercatorum, que eram: os estatutos das corporações de ofício, os consuetudini mercantili e a jurisprudência das curiae mercatorum. F. GALGANO, Lex mercatoria..., p. 37.

${ }^{431} \mathrm{P}$. KAHN, Les principes généraux du droit devant les arbitres du commerce international, in Journal du Droit International, 1989, v. 116, n. 2, pp. 322-3. E. LoQUIN, Où en est la lex mercatoria?..., p. 40, lembra que os princípios são originários de vários países. A regra de minimizar os danos (duty to mitigate) é uma regra de common law consagrada pelo Uniform Commercial Code dos Estados Unidos, mas admitida por alguns países de tradição romana (Itália, Alemanha, Hungria, Holanda, Suíça) e também pela CISG. Especificamente sobre tal princípio no comércio internacional, vide S. REIFEGERSTE, G. WEISZBERG, Obligation de minimiser le dommage et 'raisonnable' en droit du commerce international in Revue du Droit des Affaires Internationaux, n. 2, 2004, pp. 181-97.
} 
rapports internationaux, et qui sont consacrés en particulier par les usages du commerce international e par le droit international" ${ }^{\prime 32}$.

Para se caracterizar como tal, um princípio deve ser dotado de abstração e generalidade. Na nova lex mercatoria, porém, ambos são de certa forma relativizados ou mitigados.

Em relação à generalidade, "per poter parlare di principi generali, la giurisprudenza arbitrale non richiede che la regola sia universalmente accolta: ci si accontenta che essa presenti una larga diffusione" ${ }^{, 433}$.

$\mathrm{Na}$ medida em que, ao contrário dos ordenamentos estatais, a nova lex mercatoria não contém muitas regras supletivas da vontade das partes ${ }^{434}$, os princípios de um lado tornam-se ainda mais importante e, de outro, devem ser suficientes para enunciar regras específicas de comportamento. Nesse sentido, KAHN afirma que "on a également beaucoup insistè sur la necessaire concrétisation ou d'une spécialisation du principe général pour qu'il soit efficace et effectif. En effet, seule la spécialisation des principes conduirait à une rèel structuration du système en ce sens qu'il devient lisible et son fonctionnement prévisible, et les solutions ainsi déterminées reproductibles" ${ }^{\$ 35}$.

MARRELLA, ao analisar a posição ocupada pelos princípios gerais na nova lex mercatoria, faz referência a círculos concêntricos. No primeiro e menor deles, estariam os usos do comércio internacional; no segundo círculo, situar-se-iam os princípios gerais do direito contratual, que consistiria em um nível superior de abstração em relação às regras contidas nos usos; e, por fim, o terceiro e maior círculo abrangeria os princípios gerais de direito, esculpidos no artigo 38 do estatuto da Corte Internacional de Justiça ${ }^{436}$. São fonte da nova lex mercatoria tanto os princípios gerais de direito e os princípios específicos do comércio internacional ${ }^{437}$.

Os princípios gerais fornecem o elemento de estrutura do espaço transnacional, deles é possível "dégager les grandes règles qui donneront du corps à un ensemble

\footnotetext{
${ }^{432}$ A. FRIGNANI, L'arbitrato commerciale internazionale..., p. 142.

${ }^{433}$ A. FRIGNANI, L'arbitrato commerciale internazionale..., p. 142. . O autor conclui que "da quanto sopra um'altra conclusione si impone e cioè che nell'arbitrato internazionale non è verificata l'egemonia della cultura americana".

${ }^{434}$ F. OSMAN, Les príncipes généraux..., p. 18.

${ }^{435}$ P. KAHN, Les principes généraux..., p. 319.

${ }^{436}$ F. MARRELLA, La nuova lex mercatoria..., p. 712.

${ }^{437}$ B. Goldman, The applicable law..., p. 115. O reconhecimento de que tanto os princípios gerais de direito, segundo o Direito Internacional Público, quanto os princípios específicos dos contratos comerciais internacionais são fundamentais para a relação da nova lex mercatoria com os Estados, Organizações Internacionais e ONGs, já que constituem uma espécie de ordem pública transnacional, ponto de partida para o equilíbrio com direitos humanos e meio-ambiente, por exemplo. Vide itens 3.7 e 4.2 .
} 
diffus, de structurer d'un point de vue juridique des relations commerciales par hypothèse transnationales" ${ }^{\prime 38} \mathrm{e}$, assim como nos ordenamentos jurídicos nacionais, na nova lex mercatoria os princípios servem de base para novas regras jurídicas ${ }^{439}$.

Recorrentemente a nova lex mercatoria é criticada em razão de ser um conjunto vago de poucos e esparsos princípios, que nada mais seriam do que princípios gerais existentes nos respectivos direitos estatais ${ }^{440}$.

De fato, os laudos arbitrais, que evidenciam ou enunciam os princípios gerais aplicáveis pela lex mercatoria ${ }^{441}$, de maneira geral recorrem ao direito comparado para fundamentar sua decisão. Às vezes, simplesmente para encontrar um denominador comum entre os direitos estatais de cada uma das partes envolvidas na controvérsia. Esta técnica do tronco comum (tronc commun ${ }^{442}$ ) fez com que os árbitros descobrissem como o direito comparado é indispensável ${ }^{443}$.

De fato, não é incomum que os princípios gerais sejam equivalentes aos princípios de direito interno e internacional ${ }^{444}$. Entretanto, o próprio ato de seu reconhecimento como conteúdo da nova lex mercatoria não só já pressupõe uma diferenciação do princípio em questão em relação ao respectivo direito nacional, como a reafirma.

Mesmo que uma parte dos princípios seja elaborada a partir de um trabalho de síntese dos direitos nacionais, sua juridicidade deriva não das ordens jurídicas estatais, mas da lex mercatoria, que exerce um papel de ordem jurídica receptora ${ }^{445}$. Ou seja, a aplicação de um determinado princípio ou regra a título de lex mercatoria se dá não porque ele pertence a um ou outro sistema jurídico, mas porque tem caráter transnacional ${ }^{446}$.

\footnotetext{
${ }^{438}$ P. KAHN, Les principes généraux..., pp. 307 e 319.

${ }^{439}$ K. P. BERGER, The Concept of the "Creeping Codification" of Transnational Commercial Law, cf. disponível [on-line] em www.trans-lex.org/000004 [12.12.2009].

${ }^{440}$ Vide item 4.1.2.2 abaixo.

441 P. KAHN, Les principes généraux..., p. 327, aponta que "on aura pu remarquer également que les arbitres ont utilisé les principes bien au-delà de la mise en place d'une organisation somme toute technique, mais également dans une vision éthique des relations économiques internationales".

${ }^{442}$ Vide B. ANCEL, The Tronc Commun Doctrine - Logics and Experience in International Arbitration in Journal of International Arbitration, pp. 65-72.

${ }^{443}$ A. FRIGNANI, L'arbitrato commerciale internazionale..., p. 140. Segundo o autor (p. 142), a referência a “'regole comuni ai vari ordinamenti' (tronc commun) ... mi sembra una visione troppo restritiva ed insufficiente a disciplinare un intero contratto, da un lato, e pur sempre legata ad un profilo di diritto statuale, dall'altro".

${ }^{444}$ Vide item 3.5.1.3 abaixo sobre a boa-fé objetiva.

${ }^{445}$ F. OSMAN, Les príncipes généraux..., 354.

${ }^{446}$ E. LoQUIN, Où en est la lex mercatoria?..., p. 37. Os Princípios UNIDROIT expressam conceitos jurídicos autônomos, isto é, não pertencentes a um ou outro sistema jurídico específico. Assim, por exemplo as noções de hardship e mitigation of damages são estranhas à tradição romano-germânica,
} 
Proclamados e utilizados pelos árbitros, observa KAHN, os princípios “subissent une double déformation ou ils reflètent une double originalitè. Tout d'abord, ils ont un domaine d'application mondial dans la sphère du commerce international; ensuite même s'ils trouvent leur origine ou leur équivalent dans un droit national, leur expression par les arbitres entrâine toujours une transformation, une simplification, un détachement de l'origine qui permettent la transnationalisation de la règle" ${ }^{\text {,47 }}$.

Aprofundando a aplicação à esfera do comércio internacional, FRIGNANI destaca que o objeto ao qual se aplicam os princípios e seu conteúdo, em razão de uma interpretação uniforme em escala transnacional, os diferencia do conteúdo atribuído no respectivo direito nacional.

Assim, parece evidente que existem princípios próprios e específicos da nova lex mercatoria. Resta, então, indagar quais princípios são esses.

De maneira geral, os princípios podem ser divididos em princípios relacionados à (i) negociação e formação do contrato, (ii) execução do contrato e (iii) sua interpretação $^{448}$. Ou também, novamente segundo FRIGNANI, (i) conclusão e validade do contrato; (ii) interpretação; (iii) execução; (iv) sanção e remédio contra inexecução ${ }^{449}$.

A eles, FrignANi acrescenta o que ele denomina de super-princípios (Oberbegriffe): pacta sunt servanda e boa-fé ${ }^{450}$.

De fato, o pacta sunt servnda, expressão da autonomia da vontade, é pressuposto da nova lex mercatoria e espaço essencial de seu desenvolvimento. Este princípio é a regra nos contratos internacionais, ao passo que o rebus sic stantibus é exceção. MARRELlA afirma que "chiavi di volta dei due opposti principi [pacta sunt servanda e rebus sic stantibus] è il principio di buona fede su cui convergono principi codificati, dottrina, prassi arbitrale e normativa, sai nazionale che internazionale" ${ }^{\text {}} 451$.

A boa-fé objetiva é, de fato, o fundamento da nova lex mercatoria, verdadeiro sobreprincípio que deve nortear todo o conteúdo do novo ius mercatorum.

sendo oriundas do common law. Contudo, seu significado não pertence a este sistema, mas assume significado próprio no contexto dos Princípios UNIDROIT. Vide F. MARRELlA, La nuova lex mercatoria..., p. 282.

${ }^{447}$ P. KAHN, Les principes généraux..., pp. 326-7.

${ }^{448}$ F. OSMAN, Les príncipes généraux....

${ }^{449}$ A. FRIGNANI, L'arbitrato commerciale internazionale..., p. 143. O autor (p. 142) menciona que E. LOQUIN (La realitè des usages du commerce international, 1989) os divide em quatro categorias: princípios de previsibilidade; adaptabilidade dos contratos; cooperação entre as partes; ética dos negócios. ${ }^{450}$ A. FRIGNANI, L'arbitrato commerciale internazionale..., p. 143.

${ }^{451}$ F. MARRELLA, La nuova lex mercatoria..., p. 712. 
Os outros princípios gerais podem ser abstraídos não só de laudos arbitrais, mas também de outras fontes de cognição. A obra de OSMAN, por exemplo, desenvolve o tema abordando princípios referentes à negociação, formação, execução e interpretação dos contratos ${ }^{452}$.

Outra fonte importante de cognição é aquela elaborada pelo Centro de Direito Transnacional (Center for Transnational Law - CENTRAL), de Colônia, Alemanha, dirigido por Klaus Peter Berger. A lista do sítio trans-lex.org ${ }^{453}$ tem como método a creeping codification proposto por BERGER ${ }^{454}$, elaboração de lista com regras, princípios e padrões do direito comercial transnacional, como black-letter-law, já aceitos na prática arbitral e contratual internacional, a partir da unificação de diversas fontes ${ }^{455}$.

A razão de tal método seria, não só dar publicidade aos princípios, mas também superar o fato de que as tentativas tradicionais de codificar direito comercial transnacional introduziriam elemento estático contrário à própria natureza desse direito como law-in-action ${ }^{456}$. Por isso, a característica destacada como principal por BERGER é o fato de a lista ser open-ended, isto é, não ser um produto considerado acabado e definitivo, mas em constante desenvolvimento e atualização, aberto.

Os Princípios UNIDROIT para os Contratos Comerciais Internacionais são uma importante fonte de cognição desta fonte da nova lex mercatoria, que, em razão de sua importância, merece ser tratado à parte.

\footnotetext{
${ }^{452} \mathrm{~F}$. OSMAN, Les príncipes généraux....

453 cf. disponível [on-line] em http://www.trans-lex.org/browse.php?what=digest [15.12.2009]. Ressaltese, porém, que a lista contém regras que fugiriam do escopo da nova lex mercatoria. K. P. BERGER, The Concept of the "Creeping Codification"..., ressalta que "another basic difference between the UNIDROIT- and Lando-Principles on the one hand and the list procedure on the other relates to the fact that the list is not limited to the field of international commercial contract law. Rather, the list follows the decision-making practice of international arbitration and therefore contains legal principles that are related to those fields of law which play a predominant role in international arbitral case law, such as international company law, conflict of laws, rules of evidence, the international law of expropriation and general arbitration law".

${ }^{454}$ Vide K. P. BERGER, The creeping codification of the lex mercatoria, The Hague, Boston, Kluwer Law International, 1999, cuja segunda edição foi lançada em agosto de 2009. No livro, o autor lista sessenta princípios da nova lex mercatoria.

${ }^{455}$ K. P. Berger, The Concept of the "Creeping Codification".... Segundo o autor a "emphasis on arbitral case law distinguishes the list from the UNIDROIT Principles... Arbitral procedures therefore perform a dual function in the context of the creeping codification of the lex mercatoria. Firstly, parties and arbitrators are the primary addressees of the rules and principles contained in the list. Secondly, international arbitral procedures provide the procedural substratum for the 'discovery' of new rules and principles of the lex mercatoria which will then be included in the list".

${ }^{456}$ K. P. BERGER, The Concept of the "Creeping Codification"....
} 


\subsubsection{Os Princípios UNIDROIT}

Os Princípios UNIDROIT, cuja primeira edição é datada de 1994 e a segunda de 2004, consiste em um conjunto de regras aplicáveis aos contratos internacionais.

Os Princípios UNIDROIT 2004 contêm o Preâmbulo (versão 1994 com a inclusão dos parágrafos 4 e 6, assim como notas de rodapé); Capítulo 1: "Disposições Gerais" (versão 1994 com a inclusão dos parágrafos 4 e 6); Capítulo 2: Seção 1: "Formação" (versão 1994); Seção 2: “Autoridade de Agentes" (versão 2004); Capítulo 3: "Validade" (versão 1994); Capítulo 4: "Interpretação" (versão 1994); Capítulo 5: Seção 1: "Conteúdo" (versão 1994 com inclusão do Artigo 5.1.9); Seção 2: "Direitos de Terceiros" (novo); Capítulo 6: Seção 1 "Adimplemento" (versão 1994); Seção 2 "Hardship" (versão 1994); Capítulo 7: Seção 1: "Inadimplemento" (versão 1994); Seção 2: "Direito à Prestação" (versão 1994); Seção 3: "Rescisão" (versão 1994); Seção 4: "Danos” (versão 1994); Capítulo 8: “Compensação”" (versão 2004); Capítulo 9: Seção 1: “Cessão de Direitos” (versão 2004); Seção 2: “Cessão de Obrigações” (versão 2004); Seção 3: "Cessão de Contrato" (versão 2004); Capítulo 10: "Prescrição" (versão $2004)^{457}$.

Atualmente, já são ao menos 215 as decisões que aludiram aos Princípios UNIDROIT, das quais 148 provêm de tribunais arbitrais e 67 de outros tribunais, incluindo os tribunais estatais, o Centro Internacional de Solução de Disputas de Investimento (ICSID), a Corte de Justiça Européia e o Tribunal Econômico dos Estados Independentes da Commonwealth ${ }^{458}$.

Os Princípios UNIDROIT podem ser utilizados quando as partes tiverem feito referência a eles para reger o contrato, ou quando as partes tiverem feito referência aos princípios gerais de direito, à lex mercatoria ou referência equivalente, ou ainda quando as partes não tiverem feito referência a eles ${ }^{459}$.

\footnotetext{
457 A terceira edição, em desenvolvimento, incluirá os seguintes temas: efeitos da extinção de contrato não cumprido, ilegalidade, pluralidade de credores e devedores, condições e resolução de contratos de longo prazo por justa causa, cf. disponível [on-line] in http://www.unidroit.org/english/workprogramme/study050/main.htm [28.11.2009].

${ }^{458} \mathrm{Cf}$. disponível [on-line] in http://www.unilex.info/dynasite.cfm? dssid $=2377 \& d s m i d=13618 \& x=I$ [2811-2009]. Ressalte-se que o número não necessariamente reflete todas as decisões, até porque nem todos os laudos arbitrais são publicados.

459 Preâmbulo dos Princípios UNIDROT 2004, cf. disponível [on-line] in http://www.unidroit.org/english/principles/contracts/principles2004/integralversionprinciples2004-e.pdf [28-11-2009]. Além dessas aplicações, de acordo com o Preâmbulo, os Princípios UNIDROIT podem ser utilizados para interpretar ou suplementar instrumentos internacionais de direito uniforme (vide, principalmente em relação à CISG, M.J. BONELL, The UNIDROIT Principles of International Commercial Contracts and CISG ..., pp. 26-39 e The UNIDROIT Principles and Transnational Law, in
} 
Este ponto merece ser esmiuçado, até porque seus resultados são aplicáveis para a possibilidade de escolha da nova lex mercatoria para reger o contrato.

\section{a) Os Princípios UNIDROIT como sistema normativo nos tribunais estatais}

Ainda que grande parte dos Estados reconheça a faculdade da electio juris, i.e., autorizam às partes a escolha do direito aplicável a seu contrato, a escolha da lex contractus normalmente deve se restringir ao direito e normas de origem estatal.

Assim como nos Estados Unidos da América, o entendimento majoritário é de que na Europa também não é possível, nos tribunais nacionais, recorrer a direito transnacional (ou a nacional) ${ }^{460}$.

Já no sistema da Convenção Interamericana sobre Direito Aplicável aos Contratos Internacionais, de 1994, (CIDP V), em virtude dos artigos $9^{\circ}$ e $10^{\circ 461}$, a lex

Uniform Law Review, 2000, pp. 199-218., F. MARRELlA, La nuova lex mercatoria..., p. 156, F. FERRARI, General Principles and International Commercial Law Conventions - A Study of the 1980 Vienna Sales Convention and the 1988 Unidroit Conventions, in Uniform Law Review, 1997, J. BASEDOW, International Uniform Law Conventions and the UNIDROIT Principles of International Commercial Contracts, in Uniform Law Review, 2000, pp. 129-39, e também laudos arbitrais, como CCI 8128/1995 e 8817/1997, cf. disponível, respectivamente, [on-line] in http://www.unilex.info/case.cfm?pid=2\&do=case\&id=637\&step=FullText [01-09-2004] e http://www.unilex.info/case.cfm?pid=2\&do=case\&id=659\&step=FullText), para interpretar ou suplementar lei nacional, assim como podem servir como modelo ou referência para legisladores nacionais ou internacionais. Também podem ser utilizados como guia para redação de contratos. Vide, para maiores referências, M. J. BONELL, Un “codice” internazionale ..., pp. 185 e ss.

${ }^{460}$ F. MARrella, La nuova lex mercatoria..., p. 119, aponta que "nel sistema della Convenzione di Roma, e quindi, dinanzi al giudice di uno degli Stati in cui essa sia in vigore, la lex mercatoria non può assumere il rilievo alla stregua di una legge applicabile...". Para M. J. BonELL, Un "codice" internazionale..., p. 193, "secondo l'opinione tradizionale e tutt'ora dominante, le regole di conflitto restringono la scelta del diritto applicabile ai contratti internazionali ai diritti statali attualmenti vigenti, ad esclusione di ogni sistema normativo sopranazionale o a-nazionale. Ciò è confermato dalla Convenzione di Romal del 1980 sulla legge applicabile alle obligazioni contrattuali che unifica le norme di diritto internazionale privato in materia di contratti degli Stati membri dell'Unione Europea: mediante l'uso di espressioni quali 'legge di uno Stato contraente' (art. 2), 'legge straniera' (art. 3, $3^{\circ}$ comma), 'legge del paese con cui [il contratto] è piú strettamente conesso'(art. 4, $1^{\circ}$ comma), 'legge del paese in cui [il consumatore] ha la residenza abituale'(art. 5, $2^{\circ}$ comma) e così via, tale Convenzione chiarisce che la legge applicabile in ciascun caso deve essere necessariamente quella di un determinato Stato".

${ }^{461}$ Esses artigos CIDIP-V têm a seguinte redação: “Art. $9^{\circ}$ - Não tendo as partes escolhido o direito aplicável, ou se a escolha do mesmo resulta ineficaz, o contrato reger-se-á pelo direito do Estado com o qual mantenha vínculos mais estreitos. / "O tribunal levará em consideração todos os elementos objetivos e subjetivos que se depreendam do contrato, para determinar o direito do Estado com o qual mantenha vínculos mais estreitos. Levar-se-ão também em conta os princípios gerais do direito comercial internacional aceitos por organizações internacionais. / "Não obstante, se uma parte do contrato for separável do restante do contrato e mantiver conexão mais estreita com outro Estado, poder-se-á aplicar a esta parte do contrato, a título excepcional, a lei desse outro Estado. / "Art. $10^{\circ}$ - Além do disposto nos artigos anteriores, aplicar-se-ão, quando pertinente, as normas, costumes, princípios do direito comercial internacional, bem como os usos e práticas comerciais de aceitação geral com a finalidade de assegurar as exigências impostas pela justiça e eqüidade na solução do caso concreto". 
mercatoria pode ser utilizada como lex contractus sob o título de princípios gerais de direito comercial internacional aceitos pelas organizações internacionais. Entretanto, sua aplicação é muito limitada, estando em vigor apenas entre México e Venezuela.

\section{b) Os Princípios UNIDROIT como sistema normativo nos tribunais arbitrais}

Assim, em um tribunal estatal, a referência aos Princípios UNIDROIT como sistema normativo será desconsiderada, sendo aplicáveis às leis de direito internacional privado daquele país ${ }^{462}$. Isto é, à luz dos ordenamentos jurídicos estatais, a referência aos Princípios UNIDROIT não seria tida como kollisionsrechtliche Verweisung, mas mero rinvio negoziale, materiellrechtliche Verweisung ${ }^{463}$. Nesses casos, então, as disposições dos Princípios UNIDROIT serão incorporadas ao contrato como cláusulas contratuais, e sujeitas não só à ordem pública nacional, como às demais regras cogentes aplicáveis aos contratos ${ }^{464}$.

O tratamento é oposto quando as partes adotarem a arbitragem como meio de solução das controvérsias oriundas de seu contrato ${ }^{465}$, já que em geral é facultado às partes escolherem regras de direito e não somente leis nacionais ou estatais ${ }^{466}$.

\footnotetext{
${ }^{462}$ F. BoRTOLOTTI, The Unidroit Principles...., pp. 147-8.

${ }^{463}$ M. J. BONELL, Un “codice” internazionale ..., pp. 193-4.

${ }^{464}$ M. J. BonELL, The UNIDROIT Principles and Transnational Law..., p. 201, observa que "the proper law of the contract will still have to be determined separately on the basis of the rules of private international law of the forum, and the UNIDROIT Principles will bind the parties only to the extent that they do not affect the mandatory provisions of the proper law from which the parties may not derogate by agreement".

${ }^{465}$ No comentário 4 ao Preâmbulo dos Princípios UNIDROIT, ressalta-se que as "Parties who wish to choose the Principles as the rules of law governing their contract are well advised to combine such a choice of law clause with an arbitration agreement", cf. disponível [on-line] http://www.unidroit.org/english/principles/contracts/principles2004/integralversionprinciples2004-e.pdf. ${ }^{466} \mathrm{Na}$ França, por exemplo, o artigo 1496 do Código de Processo Civil estabelece que "l'arbitre tranche le litige conformément aux règles de droit que les parties ont choisies; à défaut d'un tel choix, conformément à celles qu'il estime appropriées. Il tient compte dans tous les cas des usages du commerce". Na Itália, o artigo 834 do Código de Processo Civil estabelece que "Le parti hanno facoltà di stabilire d'accordo tra loro le norme che gli arbitri debbono applicare al merito della controversia oppure di disporre che gli arbitri pronuncino secondo equità. Se le parti non provvedono, si applica la legge con la quale il rapporto è più strettamente collegato. In entrambi i casi gli arbitri tengono conto delle indicazioni del contratto e degli usi del commercio" (vide comentários a respeito de F. MARRELLA, La nuova lex mercatoria..., pp. 127-8). Assim também na Holanda, Suíça, China, também em organismos internacionais, como OMPI, cf. M. J. Bonell, Un “codice” internazionale..., pp. 204 e ss. No Brasil, o artigo $2^{\circ}$ da lei de arbitragem (Lei 9.307/1996) faculta às partes optar pela arbitragem por eqüidade ou de direito, com aplicação de regras de direito que podem ser esolchidas pelas partes(" $\$ 1^{\circ}$ Poderão as partes escolher, livremente, as regras de direito que serão aplicadas na arbitragem, desde que não haja violação aos bons costumes e à ordem pública. $\S 2^{\circ}$ Poderão, também, as partes convencionar que a arbitragem se realize com base nos princípios gerais de direito, nos usos e costumes e nas regras internacionais de
} 
Um avanço importante nessa direção foi a Lei Modelo da UNCITRAL sobre Arbitragem Comercial Internacional (1985), que em seu artigo 28(1) estabelece que "the arbitral tribunal shall decide the dispute in accordance with such rules of law as are chosen by the parties as applicable to the substance of the dispute...".

Também nesse sentido, o artigo 17(1) do regulamento do Regulamento de Arbitragem da Câmara de Comércio Internacional dispõe que "as partes terão liberdade para escolher as regras jurídicas a serem aplicadas pelo Tribunal Arbitral ao mérito da causa. Na ausência de acordo entre as partes, o Tribunal Arbitral aplicará as regras que julgar apropriadas" $\$ 67$.

\section{c) Os Princípios UNIDROIT como sistema normativo na ausência de escolha das partes}

A utilização dos Princípios UNIDROIT, como sistema normativo, só é possível em tribunais arbitrais. Portanto, a investigação sobre a possibilidade de sua aplicação, a tal título, na ausência de escolha das partes limitar-se-á a este modo de solução de controvérsias.

A solução apresentada pela jurisprudência arbitral aos casos em que as partes não tenham expressamente se referido aos Princípios UNIDROIT baseou-se na teoria da vontade implícita negativa ou escolha negativa. O Laudo CCI 7375/1996 tornou-se referência. O tribunal arbitral decidiu que "in other words, if a contract such as Contract No. 1 does not contain a choice of law provision, then this must be viewed as a 'shouting silence', at least an 'alarming silence', 'un silence inquiétant'; thus, a silence which must ring a bell and requires the Tribunal to look 'behind' so as to understand why the Parties have failed to include 'the obvious'....The Majority of Arbitrators have no reason to doubt that, indeed, none of the Parties, when entering Contract No. 1, would have been prepared to accept the other Party's national law". Os árbitros decidiram, então, pelos Princípios UNIDROIT na medida em que eles pudessem refletir "generally accepted principles and rules" 468 .

comércio)". O artigo 11 faculta ainda às partes incluir no compromisso arbitral "a indicação da lei nacional ou das regras corporativas aplicáveis à arbitragem...”.

467 Cf. disponível [on-line] in http://www.iccwbo.org/uploadedFiles/Court/Arbitration/other/rules_arb_brazilian.pdf [28-11-2009]

${ }^{468} \mathrm{Cf}$. disponível [on-line] in http://www.unilex.info/case.cfm? pid=2\&do=case\&id=625\&step=FullText [02-09-2004]. F. MARRElla, La nuova lex mercatoria..., p. 415, relata que "il collegio (arbitral)... rilevava che, nella fattispecie, tale metodo (dos vínculos mais estreitos) non era adeguato, in quanto non 


\title{
d) Os Princípios UNIDROIT são expressão da nova lex mercatoria?
}

\author{
Os Princípios UNIDROIT para os Contratos Comerciais Internacionais
} (Princípios UNIDROIT) são para GALGANO uma compilação orgânica da nova lex mercatoria ${ }^{469}$ e para LALIVE "une expression particulièrement autorisée et valable de la lex mercatoria" ${ }^{\text {"470 }}$, ressalvando-se que constituem fonte de cognição não exaustiva da

teneva in conto di un elemento fodamentale e, cioè, che la mancata scelta del diritto applicabile, lungi dall'essere casuale, era stata intenzionalmente voluta dalle parti. Oltre al tradizionale criterio della scelta positiva della legge applicabile occorreva, dunque, tenere conto della scelta implicita negativa in base al quale si riscontrava la volontà di ciascuna delle parti di non volere l'applicazione delle legga nazionale della propria controparte". As partes, assim, antes de fazerem uma opção positiva, demonstram o que não querem: a aplicação de uma lei nacional. Para maiores detalhes sobre o caso e a teoria da vontade implícita negativa vide o mesmo autor e obra, pp. 412-9, ou também, para um relato mais sucinto, M. J. BONELL, The UNIDROIT Principles of International Commercial Contracts - The first 50 or so decisions, in New Trends in International Trade Law - Contributions on the Occasion of the 10th Anniversary of the International Trade Law Course, Torino, G. Giappichelli, 2000, pp. 75-7. M. J. BONELL, Un "codice” internazionale..., pp. 228-9, ressalta que "il solo fatto che gli arbitri decidano di disattendere qualsiasi diritto nazionali e di applicare invece regole a-nazionali, quali ad. es. quelle contenute nei Principi UNIDROIT, non sarebbe sufficiente per annullare la decisione. L'unico modo per impugnare la decisione sarebbe quello di dimostrare che, applicando i Principi UNIDROIT, gli arbitri hanno sostanzialmente agito come amiable compositeurs e così facendo hanno ecceduto i limiti del loro mandato. Le probabilità di succeso di una tale argomentazione si stanno, peraltro, rivelando sempre più remote, visto che di recente si è avuta in diverse parti del mondo una serie di pronunce di corti statali, che definivano anche le decisioni arbitrali basati su non meglio specificati 'principi generali di diritto' o sulla 'lex mercatoria' come diritto secondo diritto e non ex aequo et bono". De fato, o laudo CCI 7365/ 1997 utilizou para o mérito da controvérsia os Princípios UNIDROIT como fonte de cognição dos princípios gerais de direito internacional, princípios estes a que as partes haviam se referido. Referido laudo arbitral foi impugnado na District Court, S.D. California sob o fundamento de ter o tribunal excedido a competência que lhe fora estabelecida. A corte americana não considerou procedente tal impugnação e confirmou a validade do laudo. Vide The Ministry of Defense and Support for the Armed Forces of the Islamic Republic of Iran v. Cubic Defense Systems, Inc., in M. J. BONELL, "UNIDROIT Principles - a significant recognition by a United States Court”, in Uniform Law Review, 1999, pp. 651 e ss.

${ }^{469}$ F. GALGANO, Lex mercatoria..., p. 242. GALGANO faz referência ao UNIDROIT como filtro cultural da nova lex mercatoria, dando origem a uma espécie de tecnodemocracia que, na ausência de autoridade central em nível mundial e conseqüente crise de legitimação democrática, seria uma espécie de tecnodemocracia, que espera seja iluminada, citando Montesquieu e afirmando ser preferível a democracia ao despotismo iluminado apenas em razão de não haver garantia de que o último seja iluminado. Dessa maneira, para GALGANO, em substituição à mediação política dos interesses em jogo, própria do direito estatal, os Princípios UNIDROIT, ao combinar a prática contratual com os princípios gerais de direito universalmente reconhecidos, consistindo em verdadeira mediação cultural dos juristas, de certa maneira poderiam neutralizar o caráter despótico - porque unilateral - da nova lex mercatoria, conferindo equilíbrio às relações contratuais. A reflexão sobre esta questão será feita nos itens 4.1.4 e 4.2.

470 P. LALIVE, L'arbitrage international et les Principes UNIDROIT, in Contratti commerciali internazionali e Principi UNIDROIT, M. J. Bonell e F. Bonelli (ed.), Milano, 1997 p. 80 apud . M. J. Bonell, The Unidroit Principles and Transnational Law..., pp 204-5. Nesse texto, M. J. BonELL faz a seguinte observação sobre o assunto: "Whether the UNIDROIT Principles of International Commercial Contracts are part of transnational law depends of course on the meaning one intends to give to this latter notion. If one adopts a narrow definition whereby transnational law basically consists of generally recognised principles of law and trade usages, it may be difficult to consider the UNIDROIT Principles as a whole as falling in one category or the other. On the contrary, on the basis of a broader definition whereby transnational law includes virtually all principles and rules other than those established by a particular domestic law, the UNIDROIT Principles, like other 'private' instruments such as the INCOTERMS or the UCP, are definitely part of it" (pp. 199-200). 
nova lex mercatoria ${ }^{471}$. Os laudos arbitrais, de maneira geral, também entendem que, de um modo ou outro, os Princípios UNIDROIT refletem a nova lex mercatoria ${ }^{472}$.

Sendo os Princípios UNIDROIT expressão da nova lex mercatoria ${ }^{473}$, vale refletir se o são em sua integralidade, em bloco, ou se coincidem com o novo ius mercatorum apenas em parte.

Durante sua elaboração, os Princípios UNIDROIT não só tinham como objetivo refletir conceitos de vários sistemas jurídicos, mas também buscar soluções que melhor se adaptassem ao comércio internacional, ainda que não fossem as soluções mais $\operatorname{adotadas}^{474}$. BASEDOW afirma assim que, no contexto dos Princípios UNIDROIT, a identificação dos princípios gerais implica opção por uma solução, que nem sempre é a mais adotada, mas aquela que faz a regra de direito melhor. Esse autor enfatiza que "the Principles UNIDROIT do, of course, contain some specific provisions which cannot be reconciled with a particular national law, and the courts of that country are hardly likely to regard such provisions as expressions of general principles of law. But their number is small and not sufficient to reverse the assumption of conformity (que os Princípios UNIDROIT podem ser referidos no todo como princípios gerais dos contratos comerciais internacionais) ${ }^{\natural 75}$.

Contrariamente, BONELL sustenta que os Princípios UNIDROIT são princípios gerais dos contratos comerciais internacionais apenas em relação àquelas disposições que individualmente se identificam com aqueles princípios gerais ${ }^{476}$.

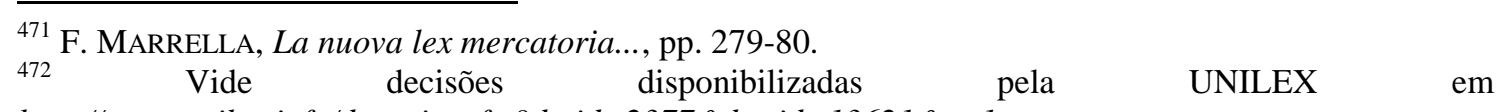
http://www.unilex.info/dynasite.cfm?dssid=2377\&dsmid $=13621 \& x=1$.

${ }^{473}$ Em sentido contrário, por exemplo, o laudo CCI 9029/1996 exclui a correspondência entre os Princípios UNIDROIT e a nova lex mercatoria, cf. A. FRIGNANI, L'arbitrato commerciale Internazionale..., p. 157.

474 Princípios UNIDROIT, 2004, Preâmbulo, p. viii, cf. disponível [on-line] in http://www.unidroit.org/english/principles/contracts/principles2004/integralversionprinciples2004-e.pdf [28-11-2009].

${ }^{475}$ J. BASEDOW, International Uniform..., p. 137.

${ }^{476}$ M. J. BonELL, The UNIDROIT Principles and Transnational Law..., pp. 204-5. O autor comenta que "scholarly opinion is divided in this point. Those in favour of this option recall that, given the uncertain nature and content such as 'general principles of law', 'lex mercatoria' or the like, it has hitherto been extremely difficult, if not impossible, to predict what arbitrators would decide when called upon to base their awards on them. Recourse to the UNIDROIT Principles would considerably reduce these uncertainties. Indeed, arbitrators would no longer be forced to work on solutions on an ad hoc basis, but have at their disposal a well defined set of rules such as the UNIDROIT Principles, considered to be 'a codification of general principles of law, lex mercatoria and the like or 'une expression particulièrement autorisée et valable de la lex mercatoria'. Those who espouse the opposite view point out that, as is openly admitted in the Introduction, the UNIDROIT Principles, far from containing only principles and rules found in many, if not all, legal systems, also lay down what are perceived to be the best solutions, even if not generally adopted. It follows that a reference by the parties to the 'general principles of law' can hardly be construed as an implicit of the UNIDROIT Principles. As to the 'lex mercatoria', this is 
Essa parece ser também a posição de MARRELLA, para quem um dos fatores para que os Princípios UNIDROIT sejam apenas codificação parcial da nova lex mercatoria é que “come insegna l'esperienza statunitense dei Restatements, i Principi possono contenere soluzione innovative che, come tali, risultano estranee agli usi del commercio internazionale, ${ }^{, 477}$.

Isto porque, como bem aponta BORTOLOTTI, há relevantes diferenças entre a noção de princípios gerais praticados pelos operadores econômicos e os Princípios UNIDROIT. Para ele, nem todas as disposições dos Princípios UNIDROIT podem ser tidas como regras da nova lex mercatoria. Sobre aquelas envolvendo hardship, afirma que "art. 3.10 in its present wording is unacceptable to international trade" and "does not reflect an actual opinio juris of the business community" 478 .

Em um dos poucos laudos que recusaram aplicação dos Princípios UNIDROIT, o tribunal arbitral decidiu que as disposições dos Princípios relativas ao hardship não refletiam a prática do comércio internacional ${ }^{479}$.

generally perceived as a very flexible and informal body of rules, so that a reference to it is even less likely to express the parties' intention to have the UNIDROIT Principles apply. Between these two extremes, the view has been expressed that precisely because the UNIDROIT Principles do not at all claim to enunciate only rules which are already accepted at international level, what is at stake is not their direct and exclusive applicability as 'general principles of law' or as the 'lex mercatoria', but merely the possibility to resort to them as one of the various sources to determine the content of these (or similar) rather vague formulations used by the parties".

${ }^{477}$ F. MARRELla, La nuova lex mercatoria..., p. 279.

${ }^{478}$ F. BORTOLOTTI, The Unidroit Principles and the arbitral tribunals, in Uniform Law Review, 2000, pp. 141 e ss.

${ }^{479}$ No Laudo CCI 8873 de 1997 decidiu-se: "En ce qui concerne les Principes des Contrats Commerciaux Internationaux rédigés par Unidroit (Principes UNIDROIT), leur Préambule prévoit expressément qu'ils s'appliquent 'lorsque les parties acceptent d'y soumettre leur contrat' et qu'ils 'peuvent s'appliquer lorsque les parties acceptent que leur contrat soit régi par les Principes généraux du droit, la lex mercatoria ou autre formule similaire. Etant donné que dans le contrat du [date] les parties n'ont fait aucune référence aux Principes en question et que la formulation de la clause sur la loi applicable permet d'exclure avec certitude que les parties aient voulu soumettre le contrat à la lex mercatoria ou aux principes généraux du droit, on ne voit pas comment les principes en question pourraient trouver application en tant que tels. Le seul moyen pour justifier leur application serait de dire qu'il s'agit d'une 'codification' des usages existants et que les 'Principes Unidroit' devraient être appliqués dans cette qualité d'usages 'codifiés' par Unidroit. Pour arriver à cette conclusion il faudrait prouver que les règles invoquées par la demanderesse (et en particulier celles sur la hardship, contenues dans les articles 6.2.1 et suivants) correspondent à un usage international généralement établi, auquel les personnes engagées dans le commerce international se considèrent liées sans besoin d'une stipulation expresse dans ce sens. Or, si l'on peut admettre l'existence d'une tendance, dans certaines branches, à stipuler avec une certaine continuité des clauses de hardship, il est certain que dans la pratique des affaires l'obligation de rééquilibrer le contrat (par la négociation et, le cas échéant, par l'intervention d'un tiers, comme prévu dans l'article 6.2.3, paragraphe 4 des Principes UNIDROIT), qui caractérise la hardship, constitue un principe tout-à-fait exceptionnel, qui n'est accepté que dans le cadre de clauses contractuelles, qui devront déterminer en détail les situations justifiant la hardship ainsi que les conséquences de celle-ci. Il est donc exclu que l'on puisse considérer les dispositions en matière de hardship contenues dans les 'Principes UNIDROIT' comme des usages du commerce. Il s'agit, au contraire, de règles qui ne correspondent pas, au moins à l'état actuel, à la pratique courante des affaires dans le commerce international et qui ne seront par conséquent applicables que lorsque les parties y ont fait une référence expresse, ce qui n'est pas le cas 
Assim, seria necessária uma análise caso a caso a fim de verificar se uma regra específica dos Princípios UNIDROIT pode ser considerada como fonte de cognição da nova lex mercatoria ${ }^{480}$. FRIGNANI, ressalta, porém, que esta posição “mortifica un po' la forza creatrice dei Principi UNIDROIT..."481.

\section{e) Como expressão da nova lex mercatoria, os Princípios UNIDROIT são princípios ou usos?}

Não há consenso sobre em qual das fontes da nova lex mercatoria se enquadram os Princípios UNIDROIT. Há decisões e doutrina caracterizando-os como usos e decisões e doutrina afirmando serem princípios.

FRIGNANI, por exemplo, sustenta que os Princípios UNIDROIT podem ser considerados como usos comerciais internacionais ${ }^{482}$. No mesmo sentido FERRARESE, para quem os Princípios UNIDROIT são uma compilação dos usos comerciais ${ }^{483}$. Há também decisões arbitrais, como, por exemplo, uma decisão de um tribunal arbitral ad hoc em Buenos Aires, de 1997, que afirmou que os Princípios UNIDROIT seriam usos

ici. Dans ces conditions, le tribunal arbitral conclut à l'inapplicabilité, dans le cas d'espèce, des 'Principes UNIDROIT' et en particulier des articles 6.2.1 et suivants en matière de hardship", cf. disponível [online] in http://www.unilex.info/case.cfm?pid $=2 \&$ do $=$ case \&id $=641 \&$ step $=$ FullText [30-08-2004].

480 O laudo arbitral 7375 proferido pela CCI (Paris) em 1996, baseando-se também no laudo 7110 de 1995 da mesma instituição, decidiu que "the Majority Arbitrators are aware that various terms are used, such as general principles of law, generally accepted principles of private law, a-national rules of law, transnational law rules, lex mercatoria, principles of international law etc. [...] As regards the reference to the UNIDROIT Principles [...] the Majority Arbitrators believe that these Principles, prepared by a working group established in 1981 and composed of leading experts and academics of all major legal systems, contain in essence a restatement of those 'principes directeurs' that have enjoyed universal acceptance and, moreover, are at the heart of those most fundamental notions which have consistently been applied in arbitral practice. On the other hand, the UNIDROIT Principles, as now laid down, have not as yet, in all their details, stood the test of detailed scrutiny in all their aspects, and thus it is at least conceivable that a particular rule would not seem to reflect the international consensus; because of this concern, the Tribunal has added the qualification 'as far as they can be considered to reflect generally accepted principles and rules"', cf. disponível [on-line] in http://www.unilex.info/case.cfm?pid $=2 \& d o=$ case $\& i d=625 \&$ step $=$ FullText, [28-08-2004]. Em relação à lei aplicável à controvérsia os árbitros decidiram da seguinte maneira: "the Tribunal will apply those general principles and rules of law applicable to international contractual obligations which qualify as rules of law and which have earned a wide acceptance and international consensus in the international business community, including notions which are said to form part of a lex mercatoria, also taking into account any relevant trade usages as well as the UNIDROIT Principles, as far as they can be considered to reflect generally accepted principles and rules".

481 A. FRIGNANI, L'arbitrato commerciale internazionale..., p. 157. F. BoRTOLOTTI, The Unidroit Principles...., pp. 144-5, por outro lado, assevera que essa identificação parcial não implica críticas aos Princípios UNIDROIT, já que estes foram elaborados para proporcionar, de forma justa e neutra, a melhor solução para o comércio internacional. $\mathrm{O}$ autor italiano afirma que "in the long run they can improve the international standard"

${ }^{482}$ A. FRIGNANI, L'arbitrato commerciale internazionale..., p. 154.

${ }^{483}$ M. R. FERRARESE, La lex mercatoria..., p 160. 
comerciais refletindo soluções de diferentes sistemas jurídicos e da prática contratual internacional $^{484}$.

$$
\text { Assim como sustentam BASEDOW }{ }^{485} \text { e } \text { BOSCHIERO }^{486} \text {, para MARRELLA, a }
$$
coincidência de alguns dos Princípios UNIDROIT com os usos é apenas pontual. Segundo ele, os Princípios UNIDROIT “comprendono certamente quella componente della lex mercatoria rappresentata dai principi generali di diritto...", caracterizando-se como princípios gerais de direito de que trata o artigo 38 do Estatuto da Corte Internacional de Justiça ${ }^{487}$. Nesse sentido, também o laudo CCI 8261/1996 relatou que "in a previous partial award on the question of the applicable law, the Arbitral Tribunal had declared that it would base its decision on the terms of the contract, supplemented by general principles of trade as embodied in the lex mercatoria. Subsequently, when dealing with the merits of the dispute, it referred, without further explanation, to individual provisions of the UNIDROIT Principles, thereby implicitly considering the latter a source of the lex mercatoria" ${ }^{488}$.

\footnotetext{
${ }^{484}$ M. J. BONELL, The UNIDROIT Principles of International Commercial Contracts - The first 50 or so decisions..., p. 79.

${ }^{485}$ J. BASEDOW, International Uniform..., p. 138. Analisando a relação dos Princípios UNIDROIT com as convenções internacionais de direito uniforme, o autor observa que "apparently judicial practice takes a different approach to what may be regarded as general: the general character of a principle does not refer to its content, but rather to its recognition by a greater number of States. If this is true, even the most technical rules contained in the principles may be treated as 'general principles' although, in practice, international uniformity will be less likely with regard to detailed rules than it is with respect to the more fundamental orientations".

${ }^{486}$ N. BOSCHIERO, La lex mercatoria nell'era della globalizzazione ..., p. 100.

${ }^{487}$ F. Marrella, La nuova lex mercatoria..., pp. 279 e ss. Segundo o autor (pp. 280-1), "i Principi Unidroit costituicono enunciazione di principi generali di diritto valevoli in materia contrattuale, enunciazione ascrivibile all'opera di un organismo internazionale. Come tali, quindi, sembra pacifico che essi vadano inquadrati tra 'i principi generali di diritto riconosciuti dalle Nazioni Civili' previsti appunto, come fonte di diritto internazionale, all'art. 38 dello Statuto della Corte Internazionale di Giustizia. I Principi Unidroit vanno inquadrati, infatti, come il risultato di un processo di specializzazione dei principi generali di diritto...”. O parágrafo $1^{\circ}$ artigo 38 da Corte Internacional de Justiça tem a seguinte redação: "A Corte, cuja função é decidir de acordo com o direito internacional as controvérsias que the forem submetidas, aplicará: a) as convenções internacionais, quer gerais, quer especiais, que estabeleçam regras expressamente reconhecidas pelos Estados litigantes; b) o costume internacional, como prova de uma prática geral aceita como sendo direito; c) os princípios gerais de direito reconhecidos pelas nações civilizadas; d) sob a ressalva do artigo 159, as decisões judiciárias e a doutrina dos juristas mais qualificados das diferentes Nações, como meio auxiliar para a determinação das regras de direito." Para a relação dos Princípios UNIDROIT com os "princípios gerais de direito reconhecidos pelas nações civilizadas" vide J. BASEDOW, International Uniform..., pp. 129 e ss., para quem "article 38 (1) (c) of the Statute of the International Court of Justice would therefore have to be read so as to mean that a uniform private law convention is to be construed in the light of general principles prevailing in the respective area of private law" (p. 134).

${ }^{488}$ Cf. disponível [on-line] in http://www.unilex.info/case.cfm?pid=2\&do=case\&id=624\&step=Abstract [19-07-2004]. Também o laudo CCI 8128/1995, por exemplo, ao fixar a taxa de juros aplicável a um determinado contrato, matéria não coberta pela CISG, declarou que o artigo 7.4.9 dos Princípios UNIDROIT pode ser considerado como um dos princípios gerais sobre os quais a CISG se fundamenta, conforme seu artigo 7(2).
} 
MARRELla adverte ainda que, embora fosse propósito da comissão de trabalho dos Princípios UNIDROIT que fossem fonte de cognição de usos comerciais internacionais, os usos são inerentes à prática dos operadores, devem refletir o "substrato sócio-econômico dos operadores". Desse modo, sendo essencialmente dinâmicos, mutáveis, os usos podem apenas ser direito não escrito de formação espontânea, com grau de abstração menor que a dos princípios gerais, não sendo possível uma codificação internacional dos usos, sob o risco de tornar os Princípios UNIDROIT obsoletos ${ }^{489}$.

Considerando o desenvolvimento histórico - continuidade e descontinuidades, principalmente com a estatização do direito comercial - a codificação de usos, como a feita pelo UNIDROIT em razão de seu processo de elaboração, realmente pode tirar-lhe a dinamicidade, necessária a seu desenvolvimento. Ressalte-se, entretanto, que usos podem ser codificados sem que tal ocorra, como é o caso dos INCOTERMS ou das Regras sobre Crédito Documentário da CCI, que seriam uma espécie de uso formulado $^{490}$.

De qualquer modo, ressalte-se que a classificação dos Princípios UNIDROIT como princípios ou usos tem pouco efeito prático. Os laudos arbitrais, como se viu, fundamentam suas decisões nos Princípios tanto de uma forma como de outra, sem que isto invalide a decisão dos árbitros.

\subsubsection{A autonomia da vontade como espaço vital da nova lex mercatoria}

No direito contratual, a autonomia da vontade se expressa "na liberdade propriamente dita de contratar, de estipular o contrato e seu conteúdo"491. Entretanto, a autonomia da vontade não é absoluta, na medida em que está sujeita a "limitações maiores ou menores ditadas pela equação do bem individual com o bem comum"492.

\footnotetext{
${ }^{489}$ F. MARRELLA, La nuova lex mercatoria..., pp. 282-3.

${ }^{490}$ Vide item 3.5.2.

${ }^{491}$ M. BASSO, A Autonomia da Vontade nos Contratos Internacionais de Comércio, in Direito e Comércio Internacional - Tendências e Perspectivas - Estudos em Homenagem ao Professor Irineu Strenger, São Paulo, LTr, p. 42. Vide, da mesma autora, Curso de direito internacional privado, São Paulo, Atlas, 2009, pp. 178-182.

${ }^{492}$ I. STRENGER, Direito do Comércio..., p. 89.
} 
A autonomia da vontade pode ser analisada sob três perspectivas ${ }^{493}$. A primeira delas diz respeito à autonomia contratual no direito interno, que se configura segundo os limites impostos por cada um dos Estados, no exercício da sua própria soberania.

MARRELla afirma que "in senso positivo, ..., l'autonomia contrattuale, esercitata nei limiti del rispetto delle norme imperative, dell'ordine pubblico e del buon costume, porta... tre applicazione distinte: $a$ ) autonomia nella scelta di un contratto tipico; $b$ ) autonomia di determinare il contenuto del contratto; $c$ ) autonomia di concludere contratti atipici" ${ }^{494}$.

O autor italiano ressalta ainda que "è quest'ultimo tipo di autonomia (contratos atípicos ou inominados ${ }^{495}$ ), concessa dallo Stato, che entra in gioco nella lex mercatoria, consetendo, dunque ai privati, di far ottenere pieno riconoscimento giuridico 'interno' a quei modelli contrattuali - sia nazionali che internazionali diffusi - che vengono ideati e praticati nel mondo degli affari, ${ }^{496}$.

No âmbito do direito internacional privado, a autonomia da vontade tem as mesmas características da autonomia da vontade sob a perspectiva do ordenamento jurídico interno, com uma diferença fundamental que guarda relação com a escolha da lei aplicável ao contrato. No ‘interior' do contrato, de acordo com a lei escolhida, há a autonomia para estabelecer o conteúdo do contrato ${ }^{497}$

Em se tratando de contratos comerciais internacionais, a lex voluntatis é amplamente reconhecida no cenário internacional, denotando-se, aliás, uma tendência à sua adoção, embora em alguns países não seja reconhecida ${ }^{498}$.

\footnotetext{
${ }^{493}$ F. MARRELLA, La nuova lex mercatoria..., p. 112.

${ }^{494}$ F. MARRELlA, La nuova lex mercatoria..., p. 112. I. STRENGER, Contratos Internacionais, p. 66, observa que "nos contratos internacionais, a vontade desempenha nítida função tipificadora, porquanto o comércio internacional, entendido como lex mercatoria que é, impõe, crescentemente, o desaparecimento dos formalismos, fazendo com que se alarguem os limites de ultrapassagem do Direito positivo, de modo a conquistar a produção de efeitos jurídicos, com penetração incontestada... Na esfera do comércio internacional, a validez e a eficácia negociais têm assentado seu princípio na máxima negotium constitutum sola voluntate".

495 Os contratos atípicos são para F. MARRELLA instrumentos de unificação espontânea do direito.

${ }^{496}$ F. MARRELLA, La nuova lex mercatoria..., p. 113.

497 E. LoQuin, Où en est la lex mercatoria?..., p. 42. O autor (p. 43) ressalta que "le principe de l'autonomie de la volontè met ainsi en concurrence l'ensemble des systèmes juridique et le jus shopping permet d'identifier et de sélectionner l'ordre juridique le plus favorable au modèle juridique contractualisé".

498 A Convenção de Roma sobre a Lei Aplicável às Obrigações Contratuais celebrada em 1980, atual Regulamento 593/2008 da União Européia, entre os países da União Européia adota a liberdade de escolha da lei aplicável. A quinta conferência interamericana sobre direito internacional privado (CIDIP V), convenção ratificada apenas por México e Venezuela (mas de que o Brasil é signatário) - cf. disponível [on-line] http://www.oas.org/juridico/english/sigs/b-56.html [1.12.2009]. No Brasil, entretanto, prevalece o entendimento de que a determinação da lei aplicável aos contratos internacionais é de ordem pública e não pode ser afastada pelas partes, aplicando-se o princípio locus regit actum (artigo $9^{\circ}$ da Lei
} 
No entanto, ao se tratar do tema, são duas as ordens a serem consideradas: a primeira relativa às cortes estatais e a segunda envolvendo a arbitragem comercial internacional.

A autonomia da vontade nos contratos internacionais é reconhecida pelos Estados não só em sede de convenções internacionais sobre direito internacional privado, mas também em convenções internacionais e leis internas em matéria de arbitragem.

Uma segunda discussão decorrente da análise da autonomia da vontade no âmbito do direito internacional privado diz respeito à possibilidade de as partes fazerem referência a lei que não tenha origem estatal, i.e., se às partes é facultada a remissão à nova lex mercatoria ${ }^{499}$.

Não obstante todas as controvérsias a respeito do tema, prevalece a opinião de que frente aos tribunais nacionais tal remissão é inválida e de que é válida em arbitragem comercial internacional ${ }^{500}$.

A terceira e última perspectiva da autonomia da vontade é aquela que envolve a derrogação da jurisdição e que se desenvolve no contexto da arbitragem. Menciona MARRELlA que "le parti godono di un'autonomia nella misura in cui l'ordinamento statale consenta alle parti di derogare alla giurisidizione del giudice interno disponendo, appunto, che l'eventuale controversia tra loro insorta venga risolta o da un giudice statale straniero oppure dagli arbitri" ${ }^{\circ 01}$.

$\mathrm{Na}$ arbitragem, essencial para a nova lex mercatoria, o princípio se desdobra na "1 - autonomia nella fissazione del locus arbitri; 2 - autonomia nella scelta del regolamento arbitrale e nella fissazione del diritto processuale applicabile; 3 autonomia nella scelta delle norme applicabili al merito della controversia; 4 autonomia nella fissazione della lingua del procedimento arbitrale; 5 - autonomia nella

de Introdução ao Código Civil). Vide M. BASso, A Autonomia da Vontade... p. 47 e ss. e, da mesma autora, Curso de direito internacional privado, São Paulo, Atlas, 2009, pp. 178-182.

${ }^{499}$ A possibilidade do depeçage e posterior liberdade quanto ao tempus eligendi iuris é um outro debate sobre a aplicação da autonomia da vontade. Vide, por exemplo, M. BASSO, A Autonomia da Vontade..., p. 53.

${ }^{500}$ As principais discussões centram-se na Convenção de Roma sobre a Lei Aplicável às Obrigações Contratuais. Vide F. MARRELla, La nuova lex mercatoria..., p. 118 e ss. Este autor, aliás, conclui que nessa perspectiva a admissão da nova lex mercatoria como lei aplicável aos contratos comerciais internacionais nos tribunais não é feita pela Europa e tampouco o é pelos Estados Unidos. No entanto, na América Latina, pelos artigos $9^{\circ}$ e $10^{\circ}$ da CIDIP - V, a lex mercatoria o seria após o filtro consubstanciado na preventiva aceitação do conteúdo por organismos internacionais.

${ }^{501}$ F. MARRELLA, La nuova lex mercatoria..., p. 125. 
nomina degli arbitri, nella fissazione delle qualifiche loro richieste e nell'esercizio dell'azione di ricusazione" ${ }^{\text {502 }}$.

Observa-se, assim, em consideração às três perspectivas apresentadas, que a autonomia da vontade é o espaço vital da nova lex mercatoria, propiciando sua existência e desenvolvimento. "Com efeito, o maior sustentáculo da lex mercatoria é a autonomia da vontade", afirma STRENGER ${ }^{503}$. Como visto, a autonomia da vontade, expressa no pacta sunt servanda, seria para FRIGNANI um super-princípio ${ }^{504}$.

Como já observado, esse espaço não é, porém, ilimitado ou absoluto. BASSO adverte que nos contratos internacionais "as limitações à autonomia das partes encontram-se justamente nas noções de ordem pública interna e internacional" ${ }^{505}$. Esta última, aliás, abrange inclusive a ordem pública própria do comércio internacional ${ }^{506}$.

\subsection{Os Princípios UNIDROIT e a autonomia da vontade}

Como expressão da nova lex mercatoria, os Princípios UNIDROIT pressupõem a autonomia da vontade, tanto é que em seu artigo 1.1. prescreve que "the parties are free to enter into a contract and to determine its content", fundamento para "an open, market-oriented and competitive international economic order" ${ }^{207}$.

Entretanto, essa liberdade não é absoluta. É condição necessária para seu exercício a harmonia com os mandamentos da boa-fé no comércio internacional. A segunda parte do artigo 1.7., segundo a qual é vedado às partes excluir ou limitar a aplicação da boa-fé, demonstra que em seu próprio cerne a autonomia da vontade é condicionada por aquele princípio.

Não obstante os Princípios UNIDROIT serem de natureza dispositiva e portanto facultarem aos contratantes "in each individual case either simply exclude their application in whole or in part or modify their content so as to adapt them to the specific

\footnotetext{
${ }^{502}$ F. MARRELLA, La nuova lex mercatoria..., p. 126.

${ }^{503}$ I. STRENGER, Direito do Comércio..., p. 91.

${ }^{504}$ A. FRIGNANI, L'arbitrato commerciale internazionale ..., p. 143.

505 M. BASSO, Curso de Direito..., p. 179. No mesmo sentido, da mesma autora, A Autonomia da Vontade... p. 53.

${ }^{506}$ I. STREnGER, Direito do Comércio..., p. 139.

507 Comentário 1 ao artigo 1.1. dos Princípios UNIDROIT 1994, cf. disponível [on-line] in http://www.unidroit.org/english/principles/contracts/principles2004/integralversionprinciples2004-e.pdf [28-11-2009]. O artigo 2.15. dispõe que "(1) a party is free to negotiate and is not liable for failure to reach an agreement", a não ser que tenha agido de má-fé. No comentário 1 a esse artigo, menciona-se que a liberdade de negociar "is essential in order to guarantee healthy competition among business people engaged in international trade".
} 
needs of the kind of transaction involved" ${ }^{108}$, parte de suas regras são cogentes e não podem assim ser afastadas por convenção entre as partes ${ }^{509}$.

Há outros exemplos de regras imperativas dos Princípios UNIDROIT, além daquelas versando sobre a boa-fé, como por exemplo as do capítulo 3, sobre validade do contrato. A esse respeito, o comentário ao artigo $3.19^{510}$, esclarece que "the provisions of this Chapter relating to fraud, threat and gross disparity to be of a mandatory character, $^{, 511}$.

GIARDINA critica a ineficácia de imputar a certas regras dos Princípios UNIDROIT natureza cogente. Afirma que "cette impossibilité de déroger à quelques uns des Principes pose des problèmes et des difficultés d'ordre général lorsque les Principes sont 1'objet d'une réception matérielle. L'autonomie contractuelle, qui dans un tel cas est exercée, ne peut - par définition - subir les limitations imposées par le caractère impératif auto-proclemé de certain Principes. Les parties restent libres d'excluire de leur contrat certaines des dispositions des Principes, indépendamment du fait que celles-ci s'autodéfinissent dispositions impératives" ${ }^{~} 512$. MAYER também é mais reticente quanto à possibilidade de um árbitro poder derrogar uma cláusula contratual clara, mas julgada excessivamente severa ou injusta em nome de princípio de força obrigatória, como a boa-fé ${ }^{513}$.

A esse respeito, BONELL observa que conferir-lhes caráter imperativo pode não ser muito muito eficiente, mas, por outro lado, "il fatto che nel sistema dei Principi UNIDROIT alcune regole assumono un valore tale da non potersi consentire alle parti di escluderle o derogarvi a proprio piacimento, è sicuramente importante per i giudici o arbitri, oppure gli stessi legislatori, allorchè dovessero richiamarvisi; ed anche le parti che intendano scegliere i Principi UNIDROIT come lex contractus possono trovare utile sapere che il loro accordo contrattuale è più corretto ed equilibrato, se non escludono

\footnotetext{
508 Comentário 1 ao artigo 1.5. dos Princípios UNIDROIT 2004, cf. disponível [on-line] in http://www.unidroit.org/english/principles/contracts/principles2004/integralversionprinciples2004-e.pdf [28-11-2009].

${ }^{509} \mathrm{O}$ artigo 1.5., in fine, estabelece que "the parties may exclude the application of these Principles or derogate from or vary the effect of any of their provisions, except as otherwise provided in the Principles" (grifos nossos).

${ }^{510} \mathrm{O}$ artigo 3.19 prescreve: "the provisions of this Chapter are mandatory, except insofar they relate to the binding force of mere agreement, initial impossibility or mistake".

511 Comentário ao artigo 3.19. dos Princípios UNIDROIT 2004, cf. disponível [on-line] in http://www.unidroit.org/english/principles/contracts/principles2004/integralversionprinciples2004-e.pdf [28-11-2009].

512 A. GIARDINA, Les PrincipesUNIDROIT sur les contrats internationaux, in Journal du droit international, 1995, p. 550 apud M. J. BONELL, Un “codice” internazionale ..., p. 99, n. 23.

${ }^{513}$ P. MAYER, Le Principe de Bonne Foi devant les Arbitres du Commerce International, in Festschrift Pierre Lalive, Basel, Frankfurt a.M., 1993, p. 549.
} 
regole fondamentali come quelle sulla buona fede o sul dolo, la violenza e l'eccesivo squilibrio, sulle clausole di esonero da responsabilità o sulla indennità stabilita per il caso di inadempimento" ${ }^{, 514}$.

Mas não apenas pelo conteúdo dos próprios Princípios UNIDROIT está limitada a autonomia da vontade. Os Princípios são de caráter não-obrigatório e, por isso, como assentado no artigo 1.4, "nothing in these Principles shall restrict the application of mandatory rules, whether of national, international or supranational origin, which are applicable in accordance with the relevant rules of private international law".

Enfatize-se que "even where, as may be the case if the dispute is brought before an arbitral tribunal, the Principles are applied as the law governing the contract, they cannot prejudice the application of those mandatory rules which claim application irrespective of which law is applicable to the contract (lois d'application nécessaire) ${ }^{, 515}$.

\subsubsection{Boa-fé objetiva}

O direito francês, no artigo 1.134 de seu Code Civil $^{516}$, estabelece a boa-fé como princípio norteador dos procedimentos e satisfação das obrigações contratuais. O BGB alemão, em seu artigo 242, em linhas gerais também o adota ${ }^{517}$.

Importante também o artigo 1.337 do Codice Civile ${ }^{518}$, que estabelece o dever de agir de boa-fé inclusive nas tratativas e formação do contrato. Essa visão foi seguida também pelo legislador português ${ }^{519}$.

No mesmo sentido, vale citar decisão do Tribunal de Roma, de 24 de janeiro de 1955, que, versando a respeito da responsabilidade pré-contratual e interesse negativo, decidiu: "la giurisprudenza della Suprema Corte e alcuni corti di merito ha assunto

\footnotetext{
${ }_{514}^{514}$ M. J. BonelL, Un “codice” internazionale ..., p. 99.

515 Comentário 3 ao artigo 1.4. dos Princípios UNIDROIT 2004, cf. disponível [on-line] in http://www.unidroit.org/english/principles/contracts/principles2004/integralversionprinciples2004-e.pdf [28-11-2009].

516 “Art. 1134: Les conventions légalement formées tiennent lieu de loi à ceux qui les ont faites. Elles ne euvent être révoquées que de leur consentement mutuel, ou pour les causes que la loi autorise. Elles doivent être exécutées de bonne foi".

517 "§ 242: Leistung nach Treu und Glauben. Der Schuldner ist verpflichtet, die Leisten so zu bewirken, wie Treu und Glauben mit Rücksicht auf die Verkehrssitte es efordern”.

518 “Art. 1337: Trattative e responsabilità precontrattuale: Le parti, nello svolgimento delle trattative e nella formazione del contratto, devono comportarsi secondo buona fede $(1366,1375,2208)$ ".

519 “Art. 227: Culpa na formação dos contratos: 1. Quem negocia com outrem para conclusão de um contrato deve, tanto nos preliminares como na formação dele, proceder segundo as regras da boa fé, sob pena de responder pelos danos que culposamente causar à outra parte".
} 
decisa posizione contro questa corrente dottrinaria ed in ripetute pronunce, ha stabilito il principio che l'obbligo di correttezza e di buona fede nelle trattative cobtrattuali deve essere inteso in senso oggetivo: non occorre cioè cercare ed accertare un particolare comportamento soggetivo di mala fede, determinato dalla prova intenzionale dell'un contraente di arrecare pregiudizio all'altro, in sé e per sé considerato indipendentemente dei motivi che l'hanno determinato, risulti o meno conforme all'obbligo generale della correttezza e della buona fede, obiettivamente intesa" ${ }^{420}$.

No Brasil, a boa-fé como regra de conduta "aparece... no Código Comercial brasileiro..., como regra genérica de interpretação dos contratos comerciais, art. 131, al. I, verbis: 'a inteligência simples e adequada, que for mais conforme à boa-fé, e ao verdadeiro espírito e natureza do contrato, deverá sempre prevalecer à rigorosa e restrita significação das palavras",521.

Apenas com o Código de Defesa do Consumidor (Lei 8.078/1990), que é informado pelo princípio da boa-fé objetiva, o direito positivo brasileiro retoma o tema. Foi porém com o artigo 442 do novo Código Civil (Lei 10.406/2002) que o princípio foi consagrado $^{522}$.

Nos contratos comerciais internacionais, nas últimas décadas, a estrita aplicação do pacta sunt servanda, porquanto essencial, esmaece-se em lugar de uma abordagem mais flexível, que se funda na imposição de obrigações de comportamento, ensejando assim um controle social dos contratos comerciais internacionais ${ }^{523}$.

O pacta sunt servanda passa, nesse contexto, a ser informado pelo princípio da boa-fé objetiva ou razoabilidade ${ }^{524}$, verdadeiro sobreprincípio e fundamento da nova lex mercatoria. OSMAN, ao apontar a boa-fé como chave para a lex mercatoria, destaca que

\footnotetext{
${ }^{520}$ in Rivista del Diritto Commerciale, v. LIV, Parte II, 1956, pp. 360, especialmente p. 369.

${ }^{521}$ LUIZ GASTÃo PAES DE BARRos LEÃES, Notas sobre a Boa-Fé e..., pp. 71 e ss.

522 "Art. 422: Os contratantes são obrigados a guardar, assim na conclusão do contrato, como em sua execução, os princípios de probidade e boa-fé".

523 K. P. BERGER, The relationship between the UNIDROIT Principles of International Commercial Contracts and the new lex mercatoria, in Uniform Law Review, 2000, p. 153. O autor menciona que a societas mercatorum necessita, além de praticidade e certeza jurídica, de flexibilidade (p. 154).

${ }^{524}$ EVERARDo NóBrega QueIRoz, O Princípio da Boa-fé Objetiva..., utiliza princípio da razoabilidade como sinônimo do princípio da boa-fé objetiva. No código civil holandês a noção de razoabilidade tem relação com boa-fé. Nos Princípios de Direito Europeu dos Contratos a noção de boa fé informa aquela de razoabilidade. Assim, conforme o artigo 1:302 (capítulo 1, seção 3), "under these Principles reasonableness is to be judged by what persons acting in good faith and in the same situation as the parties would consider to be reasonable. In particular, in assessing what is reasonable the nature and purpose of the contract, the circumstances of the case, and the usages and practices of the trades or professions involved should be taken into account".
} 
“le dénominateur commun des príncipes généraux dégagés par la jurisprudence arbitrale réside, sans aucun doute, dans le principe de bonne foi" ${ }^{525}$.

Diferentemente do pacta sunt servanda, a boa-fé abrange não só o aperfeiçoamento e execução do contrato, mas também a fase das negociações ou pourparlers $^{526}$. De fato, no laudo CCI 3131/1979, os árbitros argumentaram que "l'un des principes qui inspirent cette dernière est celui de la bonne foi qui doit présider à la formation et à l'exécution des contrats. L'accent mis sur la bonne foi contractuelle est d'ailleurs l'une des tendances dominantes que révèle 'la convergence des législations nationales en la matière...,",527.

A boa-fé objetiva é, nas palavras de Luiz Gastão PAES de Barros LEÃES, "regra de conduta, que interessa à formação e à execução dos contratos, como valor exterior à conduta dos contratantes" ${ }^{\text {} 528}$. Dela se distingue a boa-fé subjetiva, que é "o estado interior ou psicológico dos indivíduos relativamente ao conhecimento - ou ao desconhecimento - da intenção ou falta de intenção de alguém"

Denota-se, assim, que da conduta da pessoa honrada, como padrão de conduta no comércio internacional, dissocia-se o elemento subjetivo. Ou seja, trata-se de considerar o plano objetivo, exterior, da vontade. No mesmo laudo CCI 3131/1979, os árbitros apontaram que "la bonne foi exprime non seulement un état psychologique, la connaissance ou l'ignorance d'un fait, mais aussi une 'référence aux usages, à une règle morale de comportement...' ... Elle traduit alors une exigence de comportement qui peut être rapprochée du principe général de responsabilité" ${ }^{\circ 30}$.

\footnotetext{
525 OSMAN, Les príncipes généraux..., p. 18. Embora, por exemplo, EVERARDO NóBREGA QUEIROZ, $O$ Princípio da Boa-fé Objetiva..., sustente que a boa-fé sustentada por Osman é aquela de cunho éticosubjetivo. K. P. BERGER, The relationship between..., p. 160, considera a "notion of good faith and fair dealing as the Magna Charta of international trade law". Já P. MAYER, Le Principe de Bonne Foi..., p., 547, ao contrário, afirma que "la qualification (da boa-fé) de principe général du droit nous paraît abusive (est vrai que l'expression de 'principe général du droit' revêt plusieurs significations). Nous nous référons ici à la définition, à juste titre exigeante, proposée par BUREAU, D., dans sa thèse sur Les sources informelles du droit dans les relations privées internationales, Paris II, 1992, p. 61: ce sont 'des propositions non écrites dont la généralité permet de soutenir une large série de solutions positives'”.

${ }_{526} \mathrm{Com}$ a celebração - em grande escala - de contratos de longa duração (relacionais), e não mais apenas de execução imediata, reconhecer na fase negocial obrigações de caráter jurídico, e não somente moral, tornou-se imprescindível para a viabilização e desenvolvimento do comércio.

527 in Revue de l'Arbitrage, 1983, pp. 530-1, citado no laudo 5953 en 1989 cf. disponível [on-line] in www.trans-lex.org/205953 [1.12.2009].

${ }^{528}$ LuIZ Gastão PaEs De BARRos LeÃes, Notas sobre a Boa-Fé e a Lealdade Negocial, in Il Progetto UNIDROIT "Principi per i contratti commeciali internazionali" e l'unità e specifità del sistema giuridico latinoamericano, M.J. BONELl e S. CHIPANI (org.), Padova, Cedam, 1996, p. 71.

${ }^{529}$ LuIZ GaStÃo PAES de BarRos LeÃes, Notas sobre a Boa-Fé e..., p. 71.

${ }^{530}$ in Revue de l'Arbitrage, 1983, pp. 530-1, citado no laudo 5953 en 1989 cf. disponível [on-line] in www.trans-lex.org/205953 [1.12.2009].
} 
Na medida em que, ao contrário dos ordenamentos jurídicos nacionais, o novo ius mercatorum não dispõe de muitas regras supletivas, o papel da boa-fé na nova lex mercatoria tende a ser mais relevante ${ }^{531}$, sendo ponto de apoio para as decisões arbitrais. Ao ser recepcionada pela nova lex mercatoria, e se tornar seu princípio fundamental, a boa-fé objetiva assume um conteúdo transnacional, distinto daquele atribuído nos respectivos direitos nacionais. MAYER observa que o princípio da boa-fé "ne se borne pas à recevoir en son sein lés solutions consacrées par les droits étatiques; elle donne au principe de bonne foi un rôle plus dynamique, inconnu (ou invisible) dans le droit des Etats" ${ }^{, 532}$.

MARRELla observa que existe “... un generale dovere di cooperazioni tra le parti. In base a tale principio, ciascuna delle parti tenuta a cooperare con la controparte quando questa può ragionevolmente attendersi tale cooperazione per l'adempimento delle proprie obligazioni. Tale principio, che sprime in senso transnazionale di buona fede oggetiva (la corretezza dell'articolo 1175 in diritto italiano ${ }^{533}$ )..."534.

No entanto, ao sustentar a necessidade de concretização ou especialização de princípios gerais para que sejam eficazes e efetivos e, portanto, previsíveis, KAHN afirma que "l'utilisation si fréquente du principe général de droit du respecte de la bonne foi qui est le pivot du raisonnement de beaucoup de tribunaux arbitraux est plus une directive philosophique d'évaluation d'un comportement qu'une véritable règle en raison de son impécision" 535.

MAYER adverte que a boa-fé por si só é parâmetro muito genérico e que, em um caso concreto, a decisão baseada no princípio da boa-fé seria próxima da responsabilidade extracontratual, princípios de interpretação, vícios de consentimento, entre outros. Assim, segundo o jurista francês, a boa-fé não é a fonte de regras a partir das quais soluções são deduzidas. Trata-se, para ele, de uma indicação para guiar o árbitro ou juiz na tarefa de interpretação e não de um corretivo ao funcionamento das regras. MAYER conclui que a boa-fé é um conceito aberto, que insere no sistema uma forma discreta de eqüidade. Sua utilização pelos árbitros seria perfeitamente justificável, mas, em conjunto com a nova lex mercatoria, haveria um grau indesejável de imprevisibilidade. "Et il est temps, en tout cas," complementa MAYER, "de renoncer à la

\footnotetext{
${ }^{531}$ OSMAN, Les príncipes généraux..., p. 18

${ }^{532}$ P. MAYER, Le Principe de Bonne Foi..., pp. 543-4.

533 "Art. 1175 Comportamento secondo correttezza: Il debitore e il creditore devono comportarsi secondo le regole della correttezza (Cod. Civ. 1337, 1358)."

${ }_{534}$ F. MARRELLA, La nuova lex mercatoria..., p. 715.

${ }^{535}$ P. KAHN, Les principes généraux..., p. 319.
} 
croyance illusoire que l'on peut déduire de façon rigoureuse tout un corps de règles techniques à partir d'une notion morale vague, si respectable soit-elle" ${ }^{\wedge 36}$.

De fato, é essencial que o conteúdo do princípio da boa-fé objetiva seja evidenciado e delineado pela doutrina e, principalmente, por obra dos juízes e árbitros, extraindo-se deveres imponíveis às partes ${ }^{537}$.

O laudo CCI 2291/1975, por exemplo, afirmou que compreende a boa-fé a obrigação de colaboração total, leal e constante entre as partes; a obrigação de não se prejudicarem mutuamente; o dever de diligência normal, útil e constante na salvaguarda dos interesses mútuos; presunção de competência profissional; dever de minimizar perdas. Já de acordo com o laudo CCI 2508/1976, da mesma instituição, estão também compreendidos na noção de boa-fé o dever de abster-se de toda proposição ou conduta capaz de conduzir ao fracasso das negociações ou ao descumprimento dos contratos; dever de não fazer propostas insensatas ou recusar as razoáveis; ou também pelo laudo 4381/81 a obrigação de informação recíproca sobre particularidade das normas aplicáveis ao contrato; o dever de sigilo e o dever de minimizar os prejuízos de terceiros envolvidos $^{538}$. O laudo CCI 11849/2003 prevê obrigação de não se beneficiar de forma indevida dos remédios contratuais previstos em caso de inadimplemento ${ }^{539}$.

KAHN, além do dever de informar, menciona também, por exemplo, que foram evidenciados pela jurisprudência arbitral, o dever de indenizar e a responsabilidade contratual, compensação e o estoppel (ou venire contra factum proprium) ${ }^{540}$.

\footnotetext{
${ }^{536}$ P. MAYER, Le Principe de Bonne Foi..., pp. 547 e ss.

537 Vide http://daccess-dds-ny.un.org/doc/UNDOC/GEN/V04/547/56/PDF/V0454756.pdf?OpenElement para um apanhado geral dos desdobramentos da boa-fé e de sua aplicação, por julgados e laudos arbitrais, no contexto da CISG.

538 M. BASSO, Âmbito de Aplicação dos Princípios UNIDROIT sobre os Contratos Comerciais Internacionais, in Revista Jurídica UNIGRAN, 1999, pp. 55-6, e S. JARVIN e Y. DERAINS, Collection of ICC Arbitral Awards 1974-1985, The Netherlands, Kluwer Law and Taxation Publishers/Deventer, 1990, pp. 274-7; 292-6.

${ }_{539} \mathrm{Cf}$. disponível [on-line] in http://www.unilex.info/case.cfm? pid=1\&do=case \&id=1160\&step=FullText [15.12.2009].

${ }^{540}$ P. KAHN, Les principes généraux..., pp. 319 e ss. Vide P. PINSOLLE, Distinction entre le principe de l'estoppel er le principe de bonne foi dans le droit du commerce international, in Journal du Droit International, 1998, pp. 905 e ss. O autor estabelece interessante paralelo sobre a boa-fé objetiva e estoppel, conceito proveniente do direito inglês dos contratos. Afirma que o direito inglês não reconhece um princípio geral de boa-fé, mas apenas o estoppel, que naquele sistema é apenas instrumento de proteção das partes. Ao fim, mostra que o estoppel é princípio do comércio internacional.
} 


\subsection{A boa-fé objetiva nos Princípios UNIDROIT}

O princípio da boa-fé objetiva permeia todo o conteúdo dos Princípios UNIDROIT, assumindo várias formas. Exprime-se, por exemplo, na proibição de comportamento inconsistente ou venire contra factum proprium.

Desde a sua concepção, os Princípios UNIDROIT foram elaborados tendo como valor central e também objetivo a neutralidade, elaborando regras que pudessem ser aplicadas para estabelecer ou manter o equilíbrio entre as partes contratantes. Almejavase, assim, a melhor solução para o comércio internacional e não beneficiar qualquer sistema jurídico específico ou quaisquer países em determinado estágio e modelo econômico ou sofrer influências de determinados grupos de interesses.

Desta maneira, o princípio da boa-fé objetiva permeia todo o conteúdo dos Princípios UNIDROIT não só em prol do equilíbrio entre as partes contratantes, mas também da cooperação e honestidade - a correttezza italiana - entre elas.

Assim, enfatiza BERGER que "good faith and fair-dealing have thus become the central yardstick for the 'social control' of business behaviour and of the substantive fairness of any business agreement under the UPICC (Princípios UNIDROIT)”, ${ }^{, 541}$.

A primeira parte do artigo 1.7. dos Princípios UNIDROIT estabelece que "(1) todas as partes contratantes devem agir de acordo com a boa-fé e lealdade negocial (fair-dealing) no comércio internacional". A segunda parte desse artigo impede as partes de excluir ou limitar a aplicação deste princípio.

BERGER observa que "within the UPICC (Princípios UNIDROIT) the notion of good faith is qualified in that it is mentioned, in Article 1.7.(1), concurrently with the idea of 'fair dealing in international trade'. This was done so as to make it clear from the outset that the conduct of the parties is not to be measured according to the subjective standards of their bilateral (or multilateral) contractual relationship, nor according to the standards of their respective legal systems, but according to a far reaching objective standard to be found among business men in international trade, amounting to 'fairness in the market place'. This objective understanding of the notion of good faith in international business is not only in line with the approach taken in Sec 1-302 (b) UCC, but is also reflected in English legal practice where the principle of good faith is always

${ }^{541}$ K. P. BERGER, The relationship between..., p. 159. 
seen in the context of honesty, fairness and reasonableness that prevail in the relevant legal community".

Dessa forma, observa-se que os Princípios UNIDROIT são independentes quanto ao seu conteúdo. Ou seja, não estão vinculados ou têm necessariamente o mesmo significado que alguns conceitos e regras adquirem nos ordenamentos jurídicos nacionais.

É por isso que a referência à boa-fé é feita sempre em relação ao comércio internacional. Isto é, "the two concepts (good faith and fair dealing) are not to be applied according to the standards ordinarily adopted within different national legal systems. In other words, such domestic standards may be taken into account only to the extent that they are shown to be generally accepted among the various legal systems.... good faith and fair dealing must be construed in the light of the special conditions of international trade" ${ }^{, 542}$

Além disso, como elucida BonELL, o artigo 1.7.(1) "indica, innanzi tutto, che nel sistema dei Principi UNIDROIT il comportamento delle parti deve essere conforme al principio di buona fede durante l'intero ciclo vitale del contratto, inclusa la fase delle trattative. Sotto questo profilo, i Principi UNIDROIT seguono un approccio che, se è familiare alla generalità dei sistemi di civil law, non è altrettanto accettato nei sistemi di common law i quali, infatti, anche quando riescono la buona fede come principio generale, ne confinano la operatività espressamente alla sola fase esecutiva del contratto", 543 .

Ademais, é de fundamental relevância observar que mesmo nas relações comerciais internacionais o conteúdo da boa-fé objetiva não é uno. "Standards of business practice may indeed vary considerably from one trade sector to another, and even within a given trade sector they may be more or less stringing depending on the socioeconomic environment in which the enterprises operate, their size and technical skill, etc." ${ }^{544}$.

\footnotetext{
542 Comentário 2 ao artigo 1.7. dos Princípios UNIDROIT 2004, cf. disponível [on-line] in http://www.unidroit.org/english/principles/contracts/principles2004/integralversionprinciples2004-e.pdf [28-11-2009].

${ }_{543}$ M. J. BONELL, Un "codice” internazionale ..., p. 137.

544 Comentário 2 ao artigo 1.7. dos Princípios UNIDROIT 2004, cf. disponível [on-line] in http://www.unidroit.org/english/principles/contracts/principles2004/integralversionprinciples2004-e.pdf [28-11-2009].
} 
Esse princípio adquire no contexto dos Princípios UNIDROIT a função parâmetro de interpretação, tanto das suas próprias regras quanto das disposições contratuais, como se depreende dos artigos 4.1. e 4.8.

Os exemplos de desdobramentos da boa-fé nos Princípios UNIDROIT são inúmeros. Um deles é o disposto no artigo 2.1.16., que estabelece o dever de não divulgação ou utilização indevida em benefício próprio de informação sigilosa que tenha sido revelada por uma parte à outra em virtude de e durante a negociação do contrato.

Esse princípio traduz-se em grande parte na expectativa legítima gerada ao outro contratante quanto a determinado comportamento, como estabelecido de forma ilustrativa no artigo 2.1.15., segundo o qual a parte é responsável pelas perdas a que tenha dado causa em virtude da condução ou interrupção de má-fé das negociações.

A aplicação da boa-fé objetiva extrapola a formação do contrato, abrangendo também seu conteúdo e fase de execução. "In tema di adempimento", por exemplo, "si può ricordare, anzitutto, l'art. 5.1.2. ('Obbligazioni implicite') che indica la buona fede come una delle fonti di obbligazioni implicite alle parti da un determinato contratto, e l'art. 5.1.3. ('Cooperazione tra le parti') che statisce il dovere fondamentale di ciascuna parte '[di] cooperare con la controparte, quando questa può ragionevolmente attendersi tale cooperazione per l'adempimento delle proprie obbligazioni" ${ }^{\prime 545}$.

A boa-fé é de fundamental importância também no que respeita às hipóteses de renegociação do contrato, inclusive em virtude de hardship, sendo o parâmetro para a condução ao equilíbrio contratual entre as partes.

No capítulo regulando a não-execução do contrato, a boa-fé se revela, por exemplo, na impossibilidade de invocar cláusula excluindo responsabilidade se, nas circunstâncias, for injusto fazê-lo (7.1.6), nas regras sobre força maior (artigo 7.1.7.) ou também no dever de minimizar os danos gerados pelo inadimplemento da contra-parte (artigo 7.4.8.) $)^{546}$.

\footnotetext{
${ }^{545}$ M. J. Bonell, Un “codice” internazionale ..., pp. 153-4.

${ }^{546}$ Para maiores referências, vide, além das obras já citadas acima, E. A. FARnsworth E.A., Duties of Good Faith and Liability for Bad Faith Under the UNIDROIT Principles, Relevant International Conventions and National Laws, in Tulane Journal of International and Comparative Law, n. 1-2, 1994, pp. 47-63; no mesmo periódico, A. S. HARTKAMP, The Concept of Good Faith in the UNIDROIT Principles for International Commercial Contracts, pp. 65-71; G. RoBIN, Le principe de la bonne foi dans les contrats internationaux, in Revue de droit des affaires internationales, no. 6, 2005, pp. 695-727.
} 


\subsubsection{Usos Comerciais}

Como já observado ${ }^{547}$, na sociedade pós-industrial, o contrato é o instrumento de transformação do direito, na medida em que não só circula produtos jurídicos, como também os cria $^{548}$. Ou seja, o contrato é efetivamente fonte do direito. Segundo PELLET, ao traçar um paralelo entre a nova lex mercatoria e o direito internacional público, "les contrats sont, à l'ordre mercatique, ce que les traités sont au droit international; et, à leur tour, les contrats contribuent à la formations des usages, come les traités à celle de la coutume",549.

A prática contratual é, assim, talvez o mais importante elemento formador do uso comercial $^{550}$. De acordo com o laudo CCI 3540/1980, os usos comerciais consistem na "volontaria e ripetuta adozione degli stessi da parte della generalità degli operatori economici”, ressalvando-se, porém, que não é possível definir com precisão os termos ou critérios da repetitividade e generalidade, que têm uma certa elasticidade ${ }^{551}$.

Segundo o Uniform Commercial Code (UCC), "a usage of trade is any practice or method of dealing having such regularity of observance in a place, location or trade as to justify an expectation that it will be observed with respect to the transaction in question" ${ }^{552}$, definição esta próxima àquela do artigo $9^{\circ}$ da CISG e do artigo 1.9 dos Princípios UNIDROIT.

\footnotetext{
${ }^{547}$ Vide item 2.7

${ }^{548}$ F. GALGANO, Lex mercatoria..., p. 232.

${ }^{549}$ A. PELLET, La lex mercatoria “tiers ordre juridique”?..., pp. 62-3.

${ }^{550}$ Adota-se a preferência por usos comerciais em vez de costumes em razão de ser o termo mais utilizado em doutrina e laudos arbitrais, embora às vezes também façam referência aos costumes. A preferência também se justifica para distinção do direito internacional público e, por fim, porque tanto na antiga quanto na nova lex mercatoria os contratos-padrão exerçam papel fundamental na difusão dos usos, na nova lex mercatoria tais contratos estão sempre mais sujeitos e prontos a serem alterados, de forma cada vez mais veloz e de acordo com exigências mutáveis, fazendo com que o direito na sociedade industrial não seja consuetudinário na mesma medida que o direito medieval. Vide M. R. FERRARESE, Le istituzioni della globalizzazione..., p. 150 e F. GALGANO, Lex mercatoria..., p. 58, n. 27, com base em E. Roppo (Il contratto e le fonti del diritto, 2001). Além disso, ao tratar do fato de os usos do comércio internacional (distinguindo-os dos usos comerciais) na sociedade pós-industrial serem em parte escritos, por obra de entidades profissionais e outras organizações não governamentais, N. BOSCHIERO, La lex mercatoria nell'era della globalizzazione..., p. 113, ressalta que "il prodotto finale, è anch'esso molto diverso dalla tradizionale consuetudine o uso commerciale, inteso come norma astatuale non scritta, in quanto tali compilazioni di usi (como os UCP 600 da CCI, por exemplo) sono strumenti scritti che comportano regole formulate in modo preciso, in funzione delle varie situazioni considerate". Há, por fim, uma discussão sobre em que medida os usos comerciais podem efetivamente ser considerados como regras jurídicas - o que será objeto do item 4.1.2.1.

${ }_{551}$ A. FRIGNANI, L'arbitrato commerciale internazionale..., p. 143.

${ }^{552} \$ 1-303(\mathrm{c})$, disponível [on-line] in http://www.law.cornell.edu/ucc/1/article1.htm\#s1-303 [25.11.2009].
} 
Os usos, diferentemente dos princípios gerais - processo de abstração de normas jurídicas comuns a vários ordenamentos ${ }^{553}$, são a repetição no tempo de práticas difusas, modelos contratuais e de cláusulas, com a convicção de que tais práticas são ou devem ser jurídicas. Ou seja, além da repetição no tempo, o uso pressupõe a opinio iuris $^{554}$.

É a opinio iuris que preclui a possibilidade de condições gerais ou modelos contratuais de empresas se caracterizarem, de início, como usos comerciais. Dependem da adoção pelo restante dos operadores de tais condições gerais ou contratos ${ }^{555}$. Como adverte LOQUIN, “cependant, toutes les pratiques contractuelles ne peuvent être qualifièes d'usages du commerce. Même habituellment utilisées, elles ne sont pas fondées sur l'opinio juris, qui leur donnerait force obligatoire"

Alguns apontam os usos como o "nocciolo duro della lex mercatoria"557 e embora talvez não seja o mais correto ${ }^{558}$ - fato é que os usos comerciais são a principal fonte de desenvolvimento da nova lex mercatoria. Seja por sua flexibilidade - que

${ }^{553}$ E. GAILLARD, La distinction des principes généraux du droit et des usages du commerce international, in Etudes offertes à Pierre Bellet, 1991, relata como laudos arbitrais e também a doutrina por vezes se referem a uma determinada regra como uso ou princípio indistintamente, ou enquadrando tal regra de forma equivocada como um ou outro. Segundo o autor (p. 203), “dans le souci de mieux prouver son existence (da nova lex mercatoria), ses premiers partisans ont regroupé sous la même dénomination tous les éléments - usages professionnels codifiés, clauses contractuelles répétées, sentences arbitrales appliquant des principes généraux... - susceptibles de manifester la volonté des parties, des juges ou des arbitres de s'écarter de l'application d'une loi étatique désignée suivant la méthode traditionnelle des conflits de lois". Em seu texto, trata da forma com que os usos são referidos em legislação, em arbitragem e as conseqüências e, às vezes, restrições para a lei aplicável. Por fim, aponta que o alargamento da noção ou conteúdo de usos por árbitros, para acomodar algumas regras da lex mercatoria, às vezes é indevido, podendo afetar sua previsibilidade. Vide, a respeito, item 4.1.1. Segundo o autor (pp. 206-7), haveria duas concepções de usos comercrciais. De acordo com a primeira delas, "les usages du commerce international ne peuvent s'entendre que des pratiques contractuelles habituellement suivies dans une branche donnée du commerce. Il existe ainsi des usages du commerce maritime, des usages du commerce du blé ... Souvent très spécialisés, ces usages ne sont pas de nature à susciter un grand enthousiasme doctrinal. .... Ainsi compris, les usages permettent seulement, quelle que soit la loi applicable, d'interpréter la volonté des parties. Leur rôle est donc, au mieux, purement supplétif”. Já na segunda concepção, "la notion d'usage reçoit une définition beaucoup plus large. Comprenant toujours les pratiques contractuelles habituellement suivies, elle inclurait aussi les véritables règles de droit dégagées de l'observation du droit comparé ou d'autres sources internationales. Les usages se confondraient alors pour partie avec les principes généraux du droit du commerce international”.

${ }^{554}$ N. BosCHIERO, La lex mercatoria nell'era della globalizzazione..., p. 112. "Come ha osservato la Corte italiana", relata BosCHIERO, "questi usi trovano la propria origine nella spontanea adesione degli operatori del commercio internazionale a pratiche diffuse e nell'universale accettazione di clausole e modelli contrattuali utilizzati come base giuridica per determinate operazioni economiche. Ciò che transforma queste prassi in norme di diritto è appunto la loro ripetizione nel tempo e la presenza di un elemento soggetivo, dell'opinio juris generalizzata, necessária a far accetare tale prassi 'come diritto"'. A autora (p. 113) observa, ainda, que o fato de estar escrito ou codificado não diferencia o princípio do uso, como se verá a seguir.

${ }_{555}$ A. FRIGNANI, L'arbitrato commerciale internazionale..., p. 143.

${ }^{556}$ E. LOQUIN, Où en est la lex mercatoria..., p. 33.

${ }^{557}$ N. BOSCHIERO, La lex mercatoria nell'era della globalizzazione..., p. 113, com base em Fouchard.

558 Já que o núcelo duro seria formado pelos princípios gerais e, mais especificamente, por aqueles princípios que formam a ordem pública transnacional. Vide item 3.7. 
permite responder adequadamente ao desenvolvimento e às novas exigências das relações comerciais internacionais -, seja pela grande variedade de formas de expressão, os usos são a fonte mais dinâmica da nova lex mercatoria.

Recorde-se, neste ponto, como, por um lado, a estatização dos usos nos séculos XVIII e XIX $^{559}$ - a fase moderna da nova lex mercatoria - fez com que o desenvolvimento da nova lex mercatoria fosse obstado, tornando-a, em último grau, não adequada ou até obsoleta, e, por outro, a recondução dos usos como fonte de direito foi um dos fatores imprescindíveis para a formação da lex mercatoria contemporânea ${ }^{560}$. Segundo CuTLER, os usos têm sido considerados como a fonte mais consistente com o objetivo do direito privado, na medida em que "important efficiencies and economies are said to flow from the adoption of merchant custom as a source of law in comparison to negotiated international conventions" ${ }^{, 561}$.

Na nova lex mercatoria os usos, além de fonte, têm função ou relevância contratual, quando os contraentes de modo implícito ou expresso a eles fazem referência, e também meta-contratual, ou seja, de interpretação sistemática e integração das cláusulas contratuais e de preenchimento de lacunas ${ }^{562}$.

A CISG, por exemplo, determina - evidenciando a função contractual - que "the parties are bound by any usage to which they have agreed and by any practices which they have established between themselves" e que "the parties are considered... to have impliedly made applicable to their contract or its formation a usage of which the parties knew or ought to have known and which in international trade is widely known to, and regularly observed by, parties to contracts of the type involved in the particular trade concerned" $" 563$.

Já na função meta-contratual, a CISG estabelece que "in determining the intent of a party or the understanding a reasonable person would have had, due consideration is to be given to all relevant circumstances of the case including the negotiations, any practices which the parties have established between themselves, usages and any subsequent conduct of the parties"

\footnotetext{
${ }^{559}$ Vide item 3.2.3.

${ }^{560}$ Vide item 3.2.4.

${ }^{561}$ A. C. CUTLER, Private Power..., p. 220. A autora adverte que a utilização dos usos, porém, tem efeitos negativos, que serão discutidos no item 4.1.4.

${ }_{562}$ A. FRIGNANI, L'arbitrato commerciale internazionale..., pp. 158-9.

${ }^{563}$ Artigo $9^{\circ}(1)$ e (2).

${ }^{564}$ Artigo $8^{\circ}$ (1).
} 
Assim como os princípios gerais, os usos podem ser evidenciados por laudos $\operatorname{arbitrais}^{565}$. Mas há outras fontes de cognição de extrema relevância, inclusive instrumentos de soft law, na medida em que os usos dependem da adoção repetida e voluntária das partes - exatamente o fim a que se propõem esses instrumentos.

Mas, antes de serem exemplificadas algumas dessas fontes de cognição, cabe ressaltar que não é o fato de estarem escritos ou não que (des-)caracteriza um uso ou que o torna adequado à nova lex mercatoria ou obstáculo a seu desenvolvimento ${ }^{566}$.

Com efeito, BoschiERo ressalva que os modernos usos comerciais tendem progressivamente a perder a característica de fonte não escrita da criação do direito ${ }^{567}$. SCHMITTHOFF distingue entre os usos formulados e não-formulados. Os primeiros seriam atos deliberados, a cargo de entidades profissionais e outras organizações internacionais, intergovernamentais ou não governamentais ${ }^{568}$, como por exemplo a CCI, FIDIC, ORGALIME, UNCITRAL, entre outros. "Unformulated custom, in contrast", segundo CUTLER, "is constituted by practices that are in common usage, such as marine insurance certificates, but that have not been deliberately or formally articulated by formulating agencies" $" 569$.

Note-se como a noção de usos formulados e não-formulados compartilha pontos comuns com a idéia de neo-espontaneidade e espontaneidade de TEUBNER. Para ele, nem sempre os usos fundamentam-se na coordenação informal, mas surgem a partir de processos organizados, de modo que "estamos diante de uma mescla de processos espontâneos e organizados" ${ }^{\text {570 }}$.

\footnotetext{
565 E. LoQuin, Où en est la lex mercatoria..., pp. 32-3, que menciona os laudos CCI 3130/1981, 1675/1980 e 2139/195, assim como decisões da Cour d'appel de Paris e da Cour de cassation.

${ }^{566}$ Assim, os efeitos negativos da codificação dos usos nos séculos XVII e XVIII não provieram exatamente do fato de serem escritos ou não, mas principalmente do método da codificação e do espaço para desenvolvimento e mudança.

${ }_{567}$ N. BosChIERO, La lex mercatoria nell'era della globalizzazione..., p. 112. "Come ha osservato la Corte italiana", relata BOSCHIERO, "questi usi trovano la propria origine nella spontanea adesione degli operatori del commercio internazionale a pratiche diffuse e nell'universale accettazione di clausole e modelli contrattuali utilizzati come base giuridica per determinate operazioni economiche. Ciò che transforma queste prassi in norme di diritto è appunto la loro ripetizione nel tempo e la presenza di un elemento soggetivo, dell'opinio juris generalizzata, necessária a far accetare tale prassi 'come diritto"'. A autora (p. 113) observa, ainda, que o fato de estar escrito ou codificado não diferencia o princípio do uso, como se verá a seguir.

${ }_{568}$ C. SCHMITTHOFF, International Business Law... pp. 34-5.

569 A. C. CUTLER, Private Power..., p. 220. Segundo a autora, "while formulated international custom has unquestionably gained legitimacy as a source of law, as is evidenced by the widespread use of Incoterms and other standards developed by nongovernmental formulating agencies, the legitimacy of unformulated custom remains controversial".

${ }^{570}$ G. TEUBNER, Direito, Sistema e Policontexturalidade..., p. 109.
} 
Em relação aos usos formulados, a CCI tem importante influência na elaboração de cláusulas-padrão, tais como a cláusula arbitral, a de força maior, hardship, e também os INCOTERMS, relacionados a obrigações, transporte e regime de responsabilidade nos contratos de venda e compra internacionais. Além disso, a CCI publicou as Regras Uniformes para Garantias sob Demanda (Uniform Rules for Demand Guarantees $U R D G$ ), as Práticas e Costumes Uniformes para Créditos Documentários (Uniform Customs and Practice for Documentary Credits - UCP 600), Regras Uniformes para Cobrança (Uniform Rules for Collections - URC 522), as Regras para Documentos de Transporte Multimodal, em conjunto com a UNCTAD (UNCTAD/ICC Rules for Multimodal Transport Documents), entre outros ${ }^{571}$.

Ao lado das cláusulas-padrão, a prática contratual se apóia nos contratos-tipo ou modelos contratuais, principalmente aqueles atípicos ${ }^{572}$. Antes, importante recordar que a nova lex mercatoria se consubstancia essencialmente na referência a regras não vinculadas a um particular direito nacional. Ou seja, o contrato exige um grau de desnacionalização. Isto não significa, porém, que o contrato seja sem lei (contrat sans loi) ou é executado no espaço, até porque, como já observado, a lex mercatoria não regula determinadas matérias, como capacidade das partes, transferência de propriedade entre outras. Além disso, o contrato deve ser executado em um ou mais países - o que significa que ele estará sujeito às leis de aplicação necessária daquele(s) ordenamento(s) jurídico(s). De certa maneira, é possível afirmar que o contrato se desnacionaliza ou desterritorializa para, no momento da execução, se renacionalizar ou reterritorializar.

Segundo MARRELlA, "il contratto internazionale, dunque, al pari dei processi economici di cui è espressione, si desnazionalizza e si differenzia dal contratto interno trovando nei principi generali di diritto e nell'elaborazioni dottrinale il proprio spazio vitale" $" 573$.

A função desses contratos desnacionalizados é, da mesma forma que a própria lex mercatoria, buscar certa unidade do direito dentro da unidade do mercado ${ }^{574}$. É por isso que, nesse contexto, complementa GALGANO, "la produzione in serie su scala

\footnotetext{
${ }^{571}$ Vide www.iccwbo.org.

572 Como salienta F. MARRElla, La nuova lex mercatoria..., p. 162, principalmente aqueles contratos terminados em ing, tais como leasing, factoring, franchising, entre outros.

${ }^{573}$ F. MARRELLA, La nuova lex mercatoria..., p. 269.

${ }^{574}$ F. GALGANO, Lex mercatoria..., p. 235.
} 
planetaria esige una contrattazione altretanto in serie. Sui mercati mondiali le multinazionali debbono contrattare a condizioni uniformi" ${ }^{\text {,575. }}$.

A partir do século XIX, e com maior intensidade, no decorrer do século XX e agora XXI, as entidades profissionais cada vez mais elaboraram contratos-tipo. Contudo, esses modelos contratuais podem ser um fator de desequilíbrio das posições contratuais $^{576}$.

BONELL adverte que "tali strumenti contratuali sono stati predisposti prevalentemente da singole imprese o da associazioni di categoria operanti sulle principali piazze di commercio internazionale, quasi tutte situate nei paesi industrializzati. Di conseguenza, nella maggior parte presentano un carattere unilaterale, oltre ad essere inevitabilmente influenzati dai concetti giuridici dei respetti paesi d'origini" ${ }^{577}$.

Em um contexto como esse, torna-se fundamental então elaborar e disponibilizar contratos-tipo que sejam equilibrados, neutros.

A sua comissão de Prática Comercial Internacional da CCI tem elaborado alguns importantes contratos-tipo, como o modelo de contrato de representação comercial internacional (ICC Model Commercial Agency Contract), o modelo de contrato de distribuição (ICC Model Distributorship Contract), o modelo de contrato de intermediação ocasional de neócios (Model Occasional Intermediary Contract - NonCircumvention and Non-Disclosure agreement), o modelo de contrato de compra e venda de bens manufaturados para revenda (ICC Model International Sale Contract Manufactured goods intended for resale), o modelo de contrato de franquia internacional (ICC Model International Franchising Contract), o modelo de contrato de fornecimento turnkey de planta industral (ICC Model Contract for the Turnkey Supply of an Industrial Plant), o modelo de contrato de fusões e aquisições - aquisição de ações (ICC Model Mergers \& Acquisitions Contract - Share Purchase Agreement), modelo de acordo de confidencialidade (ICC Model Confidentiality Agreement), o modelo de contrato turnkey para grandes projetos (ICC Model Turnkey Contract for

\footnotetext{
${ }^{575}$ F. GALGANO, Lex mercatoria..., p. 235. O autor complementa que "l'uniformità internazionale di questi modelli è, per le imprese che li praticano, un valore sommo" em virtude da racionalidade de administração (em escala global) que as norteiam.

${ }_{577}^{576}$ Principalmente quando elaborados pelas grandes empresas e grupos empresariais.

${ }^{577}$ M. J. BONELL, Un “codice” internazionale ..., p. 18.
} 
Major Projects), o modelo de contrato de transferência internacional de tecnologia (ICC Model International Transfer of Technology Contract), entre outros ${ }^{578}$.

O cerne das vantagens dos modelos disponibilizados por essa instituição é o da neutralidade. Relata BORTOLOTTI que "the ICC model contracts do not have the purpose of providing the best possible contractual solutions for one of the parties involved..., but, on the contrary, they intend to state a set of contractual rules of a more neutral nature, equally acceptable to both parties"

Dois são os fatores dessa neutralidade. Além de não serem os modelos elaborados por qualquer das partes, o objetivo é o de facultar às partes a remissão a um padrão internacional em alternativa às leis nacionais que podem ser fator de desequilíbrio $^{580}$. E é exatamente por esse motivo que "the ICC has decided to base these agreements as far as possible on neutral ground, detached from specific national legislations, by having recourse to the so called lex mercatoria" ${ }^{" 581}$. No Model Occasional Intermediary Contract (Non-circumvention and Non-Disclosure agreement) faz-se referência ainda aos Princípios UNIDROIT para os Contratos Internacionais.

Outras diversas instituições elaboram contratos-tipo. Uma delas é a FIDIC, que publicou, por exemplo, as condições contratuais para construção, condições contratuais para construção e design, condições contratuais para contratos EPC (Engineering Procurement Contracts)/Turnkey, entre outros ${ }^{582}$.

Já o International Trading Centre UNCTAD/OMC reúne dezenas de contratostipo elaborados pelas mais diversas entidades ${ }^{583}$. Estão disponíveis, por exemplo, da GAFTA (The Grain and Feed Trade Association) o contrato C.A.F., ou seja, o contrato de condições gerais de custo, seguros e frete, assim como o F.O.B. (franco à bord ou free on board), contrato de fornecimento europeu - termos gerais, assim como contratos específicos, como aqueles para farinhas alimentares de carnes ou peixes em sacos,

\footnotetext{
578 Vide www.iccwbo.org.

${ }^{579}$ F. BoRTOLOTTI, The ICC Model Contracts, in New Trends in International Trade Law - Contributions on the Occasion of the $10^{\text {th }}$ Anniversary of the International Trade Law Course, Torino, G. Giappicheli, 2000, p. 82.

${ }^{580}$ F. BORTOLOTTI, The ICC Model Contracts..., p. 82. BORTOLOTTI assinala que "there is, of course, a practical way to overcome the problem of conflicting domestic rules, which consists in imposing the choice its own law on all foreign partners: so a powerful principal can submit all his contracts with a network of agents (or distributors) established in different countries to the same law, normally the law of its own country; or a strong buyer can insist on the application of his own law with sellers of different countries. However, this way of reaching uniformity at the cost of the weaker party cannot be considered as a fair solution, since it forces one of the parties to accept a law which it does not know, while giving the other party the advantage of negotiating the contract clauses under a law it is familiar with".

${ }^{581}$ F. BORTOLOTTI, The ICC Model Contracts..., p. 85.

${ }^{582}$ Vide www.fidic.org.

${ }^{583}$ Vide www.jurisint.org.
} 
contratos para entregas de produtos da Europa central e da Europa oriental, para entrega de leguminosas e outros alimentos a granel, entre outros tantos.

Estão também disponíveis contratos elaborados pela própria UNCTAD/OMC, como o contrato de compra e venda internacional de alimentos internacionais, acordo de confidencialidade e de transferência de tecnologia, assim como os elaborados pela União Internacional de Representantes e Agentes Comerciais, como o contrato de representação comercial, entre outras entidades.

\subsubsection{Arbitragem}

A escolha da nova lex mercatoria para reger um contrato ou uma disputa só é possível em arbitragens comerciais internacionais, em razão da possibilidade de escolha de regras de direito, que abrangem regras provenientes tanto de ordenamentos jurídicos estatais quanto de outras fontes não fundadas no(s) Estado(s).

Estima-se que aproximadamente $80 \%$ dos contratos comerciais internacionais contenham cláusula arbitral $^{584}$. Embora impossível de se aferir com precisão, uma vez que apenas uma parte pequena dos contratos efetivamente acaba em litígio, é possível afirmar que a previsão de solução de disputas por arbitragem, nesses contratos, é a larga maioria (embora tenda a menos do que os $80 \%$ ) e a atribuição da solução das disputas contratuais pelos tribunais estatais é menos comum ${ }^{585}$.

As vantagens normalmente atribuídas à arbitragem se pautam principalmente na celeridade, sigilo, relação custo benefício do procedimento ${ }^{586}$. Além disso, os árbitros são tidos como experts, familiarizados com a matéria e sua complexidade.

Segundo CUTLER, o racional da preferência pela arbitragem é a percepção de que é mais eficiente, mais neutra e mais confiável do que as cortes nacionais, sendo central a seu sucesso "the operation of large law firms and lawyers trained in the 'virtue' of arbitration. They are the 'organic' intellectuals who work to disseminate the arbitration ethos locally, through national government and business circles, and globally, through

\footnotetext{
584 Cf. pesquisa realizada pela CENTRAL, disponível [on-line] in http://www.translex.org/output.php?docid=000003 [15.12.2009] e F. MARRELLA, La nuova lex mercatoria tra controversie..., p. 258.

585 Alguns, como K. P. BERGER, The creeping codification... p. 70, e W. KONRADI; H. FIX-FIERRO, Lex mercatoria in the mirror..., p. 215, apontam que o índice seria de $90 \%$.

${ }^{586}$ A celeridade e custo benefício nem sempre são verificadas na prática, principalmente nos casos de arbitragens complexas e multiparty, cujos custos são bastante elevados e o prazo para solução definitiva do litígio ultrapassa o usualmente esperado.
} 
the operations of multinational law firms, international business associations, such as the ICC, and globalized arbitration practices" ${ }^{\text {"587. }}$.

Basta notar a convergência das legislações nacionais em relação à arbitragem nesses moldes. A Lei-Modelo da UNCITRAL, de 1985, foi adotada por mais de 60 países. Nos últimos 20 anos, diversos países, incluindo o Brasil, adotaram novas leis de arbitragem que, de maneira geral, não se distanciam da Lei-Modelo ${ }^{588}$. Ao lado de leis receptivas à arbitragem comercial internacional, são 144 os Estados que ratificaram a Convenção de Nova Iorque sobre o Reconhecimento e a Execução de Laudos Arbitrais Estrangeiros, de 1958, que facilita a efetividade das decisões arbitrais. Desses Estados, em quase 70 - dentre eles o Brasil (2002) - a Convenção entrou em vigor nos últimos 20 anos, o que demonstra o aumento da procura pela arbitragem também pelos países menos desenvolvidos, como, por exemplo, Afeganistão (em vigor desde 2005), Gabão (em vigor desde 2007) e Ruanda (em vigor desde 2009).

Entre 1999 e 2008, a CCI registrou um aumento de pouco mais de $25 \%$ nos pedidos de arbitragem (529 e 663, respectivamente), sendo que entre 2007 e 2008 houve um aumento de $10 \%$ (599 e 663, respectivamente) ${ }^{589}$.

$\mathrm{O}$ aumento é refletido também na proliferação dos centros de arbitragem. Em 1992, o Instituto Asser listou 120 instituições arbitrais pelo mundo ${ }^{590}$. Atualmente, segundo o International Trading Centre UNCTAD/OMC, seriam ao menos 175 instituições arbitrais ${ }^{591}$. Entre elas, as mais importantes são a CCI, a London Court of International Arbitration e a American Arbitration Association. Para investimentos, vale citar The International Centre for the Settlement of Investment Disputes, do Banco Mundial (ICSID).

Ao lado da autonomia da vontade, SchMitThOFF aponta que a arbitragem comercial internacional funda a nova lex mercatoria ${ }^{592}$. Segundo FRIGNANI, "la giurisprudenza arbitrale internazionale, grazie alla sempre più frequente pubblicazione

\footnotetext{
587 A. C. CUTLER, Private Power..., p. 226. Embora alguns juristas, como B. Goldman, Frontières..., pp. 177 e ss., tenham sustentado que a arbitragem tem o condão de preservar as relações das partes, de modo a organizar a convivência harmoniosa das partes no futuro - papel este que é exercido pela mediação, atualmente é possível perceber a arbitragem como procedimento adversarial.

588 Cf. disponível [on-line] in http://www.uncitral.org/uncitral/en/uncitral_texts/arbitration/1985Model_arbitration_status.html [15.12.2009].

${ }^{589}$ ICC International Court of Arbitration Bulletin, 2009, Vol. 20 No. 1, cf. disponível [on-line] in www.iccdrl.com [15.12.2009].

${ }^{590}$ Cf. relatado por A. C. CUTLER, Private Power..., p. 225.

${ }^{591}$ Vide http://www.jurisint.org/en/ctr/2_1_2.html. Para um apanhado das principais instituições arbitrais, vide A. FRIGNANI, L'arbitrato commerciale internazionale..., pp. 42 e ss.

${ }^{592}$ C. SCHMITTHOFF, International Business Law...., p. 29.
} 
dei lodi, che diventano di facile reperibilità per gli addetti ai lavori, è fonte di natura costitutiva" ${ }^{, 593}$. Da mesma forma, OSMAN afirma que "il existe donc une jurisprudence arbitrale, reflet d'un droit prétorien anational qui constitue, à côte des usages corporatifs, une source formelle de la lex mercatoria"

Para MARRELla, a arbitragem é o momento jurisdicional do novo ius mercatorum, sendo instrumento de leitura da "mundialização" do direito e instituto pelo qual a nova lex mercatoria emerge, se cristaliza e se coordena com o direito estatal e interestatal $^{595}$.

Os laudos arbitrais evidenciam - e em certa medida criam $^{596}$ - princípios da nova lex mercatoria. Segundo OSMAN, a tendência dos árbitros é de extrair regras jurídicas anacionais de conduta a partir da apreensão de exigências morais, sendo esta "la raison pour laquelle les principes généraux anationaux... ne peuve que procéder d'une ouevre prétorienne: celle des arbitres du commerce international, président positiviement à l'emergence et à la consécration desdits principes"597.

Tanto os princípios gerais como os usos próprios do comércio internacional enunciados em laudos arbitrais ${ }^{598}$ servem de referência para casos futuros.

Como observado no laudo CCI 4131/1982, as decisões dos tribunais arbitrais formam progressivamente uma jurisprudência que deve ser levada em consideração em laudos futuros - na medida em que deduz a conseqüência da realidade econômica e é conforme as necessidades do comércio internacional, às quais devem responder regras específicas, estas também elaboradas progressivamente, pela arbitragem internacional $^{599}$. São os árbitros que realizam a articulação entre regras de caráter geral e especial, elaborando regras cada vez mais especializadas para reger os contratos internacionais ${ }^{600}$.

Embora os laudos arbitrais não sejam precedentes no sentido do stare decisis da common law, na medida em que não há hierarquia organizada entre os tribunais

\footnotetext{
${ }^{593}$ A. FRIGNANI, L'arbitrato commerciale internazionale ..., p. 160.

${ }^{594}$ F. OSMAN, Les principes généraux..., p. 321.

${ }^{595}$ F. MARRELLA, La nuova lex mercatoria..., p. 125.

596 Segundo F. OSMAN, Les principes généraux..., p. 355, "les principes de la lex mercatoria sont en réalitè l'expression d'un droit prétorien, parce que l'autoritè qui les constate, qui est en même temps celle qui les crée, est l'arbitre".

597 Segundo F. OSMAN, Les principes généraux..., p. 355, "les principes de la lex mercatoria sont en réalitè l'expression d'un droit prétorien, parce que l'autoritè qui les constate, qui est en même temps celle qui les crée, est l'arbitre".

${ }^{598}$ E. LOQUIN, Où en est la lex mercatoria..., pp. 32-3.

${ }_{599}$ As críticas, como a de KASSIS, a respeito da jurisprudência arbitral serão tratadas no item 4.1.2.3.

${ }^{600}$ F. OSMAN, Les principes généraux..., p. 354.
} 
arbitrais, FRIGNANI destaca que, "infatti, ben raramente ci si discosta da una serie costante di precedenti arbitrali, se non per dire che essi non se applicano al caso concreto o che essi sono contrari ad una norma especifica (nazionale) da applicarsi nel caso concreto" 601 .

Além dos boletins dos centros de arbitragem, compilações e outros periódicos ${ }^{602}$, as bases de dados que disponibilizam laudos proferidos em arbitragens comerciais internacionais - na maioria dos casos, sem referência a dados que identifiquem as partes - são cada vez mais comuns.

A UNILEX ${ }^{603}$, por exemplo, é um valioso instrumento para acesso a decisões relacionadas aos Princípios UNIDROIT e à CISG. Em relação à CISG, há também a base de dados da UNCITRAL ${ }^{604}$ e do Instituto de Direito Comercial Internacional da Universidade Pace ${ }^{605}$, base esta que além de decisões arbitrais, disponibiliza decisões de tribunais estatais, comentários e doutrina relacionados a cada um dos artigos.

Há também a base de dados Kluwer Arbitration ${ }^{606}$, a Arbitration Database D07 $^{6}$ e a Dispute Resolution Library da CCI, em que é possível ter acesso a laudos arbitrais a partir de $1986^{608}$.

\subsection{Lex mercatoria setorial}

Paralelamente à vocação universal da nova lex mercatoria, desenvolve-se em seu bojo uma tendência de setorização comercial. Trata-se de uma relação de complementaridade e não paradoxal, à semelhança do que ocorre com a internacionalização e regionalização da economia. Nesse sentido, MARRELLA afirma que "accanto ad una lex mercatoria a vocazione universali, i cui principi tendono a regolare la totalità dei contratti internazionali, si giustappone, da sempre, una lex mercatoria a vocazione settoriale: ad un processo di specializzazione di principi ed usi

\footnotetext{
${ }^{601}$ A. FRIGNANI, L'arbitrato commerciale internazionale..., p. 161.

${ }^{602}$ Como por exemplo, The Collection of ICC awards, The ICC International Court of Arbitration Bulletin, o Journal of International Arbitration, a Revue de l'arbitrage e Uniform Law Review, entre tantas outras publicações.

${ }^{603}$ www.unilex.info.

${ }^{604}$ http://www.uncitral.org/uncitral/en/case_law/digests/cisg.html. A UNCITRAL disponibiliza também uma base de dados sobre a Lei-Modelo de Arbitragem: http://www.uncitral.org/uncitral/en/case_law/thesauri.html.

${ }^{605}$ www.cisg.law.pace.edu.

${ }^{606}$ www.kluwerarbitration.com e kluwerarbitrationblog.com.

${ }^{607}$ www.arbitration.fr.

${ }^{608}$ www.iccdrl.com.
} 
degli scambi si accompagna un processo di specializzazione degli stessi, limitatamente a alcune materie" ${ }^{\circ 09}$.

A principal razão para identificar essa espécie de lex mercatoria setorial consiste no papel dos usos e da arbitragem na nova lex mercatoria - isto é, dela são fontes constitutivas.

Tanto a CISG quanto os Princípios Unidroit prevêem expressamente a especialização das práticas e usos. $\mathrm{O}$ artigo $9^{\circ}$ da CISG prevê que "the parties are bound by any ... practices which they have established between themselves" e que "the parties are considered... to have impliedly made applicable to their contract or its formation a usage of which the parties knew or ought to have known and which in international trade is widely known to, and regularly observed by, parties to contracts of the type involved in the particular trade concerned".

De forma muito semelhante, segundo os Princípios UNIDROIT, “(1) the parties are bound by any usage to which they have agreed and by any practices which they have established between themselves; (2) he parties are bound by a usage that is widely known to and regularly observed in international trade by parties in the particular trade concerned except where the application of such a usage would be unreasonable".

A participação das entidades profissionais na formação dessa nova lex mercatoria circunscrita a uma determinada região ou setor econômico é decisiva. Por um lado, consolidam e difundem práticas e usos comuns a um determinado setor - que podem se expandir para outras searas -, principalmente com a elaboração dos contratostipo. Por outro, várias dessas entidades têm centros próprios de arbitragem, principalmente quando relacionadas ao comércio internacional de matérias primas e commodities. Como já observado, os laudos arbitrais também consolidam, difundem, evidenciam e enunciam princípios gerais e usos aplicáveis, interpretando-os em consideração às necessidades do setor específico.

FRIGNANI, por exemplo, destaca a existência da Corn Association, Federation of Oils, Seeds and Fats Associations (FOSFA), The Grain and Feed Trade Association (GAFTA), Europatat (RUCIP, ligada ao comércio de batatas), International Wool Textile Organization ${ }^{610}$. No setor marítimo, enfatiza o papel da Society of Maritime Arbitration, em Nova Iorque, da London Maritime Arbitration Association e do Instituto

\footnotetext{
${ }^{609}$ F. MARRELLA, La nuova lex mercatoria..., p. 89.

${ }^{610}$ A. FRIGNANI, L'arbitrato commerciale internazionale..., pp. 45 e ss.
} 
maritime de arbitraje y contratación, em Madri ${ }^{611}$. Na Itália, FRIGNANI realça também a existência da Camera Arbitrale Italiana delle Pelli, Camera Arbitrale Italiana per il Commercio dei Cereali e Semi, camera arbitrale italiana della Associazione granaria italiana e a Camera Arbitrale dell'Associazione Cotoniera Italiana.

Em outros setores, vale recordar do Tribunal Arbitral du Sport, em Lausanne, as arbitragens realizadas pela Organização Mundial da Propriedade Intelectual. Especial menção merece a Féderation Internationale des Ingénieurs-Conseils (FIDIC). Em seu contrato-tipo para construção de plantas industriais na modalidade turn-key há a previsão de escalonamento do recurso à arbitragem. Em caso de disputas, primeiro recorre-se ao Dispute Settlement Body (DSB), formado por pessoas muito mais próximas e cientes da execução do contrato em seu dia-a-dia, o que ajuda a solucionar controvérsias pequenas. Apenas após o $D S B$, as partes recorrem à arbitragem CCI.

KONRADI e FIX-FIERRO mencionam também a indústria madeireira, a indústria bancária, o setor de seguros e re-seguros ${ }^{612}$. OLGIATI menciona a lex petrolea e a lex maritime $^{613}$. Já Bernstein tem dois estudos interessantes, um sobre a indústria do algodão e outro sobre a indústria de diamantes ${ }^{614}$

\subsection{Ordem pública}

A autonomia da vontade, embora pressuposto da nova lex mercatoria, não é absoluta ou ilimitada, estando limitada à ordem pública interna e internacional ${ }^{615}$.

Os contratos comerciais são, na sua formação, desterritorializados e, na sua execução, re-territorializados, na medida em que seu cumprimento deve-se dar em algum Estado.

\footnotetext{
${ }^{611}$ Vide também T. TREVES, Lex Mercatoria Dei Naviganti, in Sociologia del Diritto, v. 32, n. 2-3, 2005, pp. 379-82.

${ }^{612}$ Vide também P. T. MUCHLINSKI, Global Burkowina Examined ..., pp. 86-7.

${ }^{613}$ W. KONRADI; H. FIX-FIERRO, Lex mercatoria in the mirror..., pp. 218-21.

${ }^{614}$ L. BERnSTEIN, Opting out of the Legal System - Extralegal Contractual Relations in the Diamond Trade, in Journal of Legal Studies, pp. 115-57, e Private commercial law in the cotton industry - creating cooperation through rules, norms and institutions, in Michigan law Review, 2001, pp. 1724-90.

${ }^{615}$ M. BASSO, Curso de Direito..., p. 179. No mesmo sentido, da mesma autora, A Autonomia da Vontade... p. 53. Ressalte-se, porém, que se por um lado a regra de ordem pública transnacional limita e condiciona a autonomia da vontade, por outro, pode favorecê-la. Isto porque, em certas condições excepcionais, um árbitro pode vir a desconsiderar regras de um determinado Estado contrárias à liberdade das partes quanto ao comércio. Vide P. LaLIVE, Ordre Public Transnational (ou Réellement International) Et Arbitrage International, trad. port. de P. B. CASELLA, Ordem pública transnacional e arbitragem internacional - conteúdo e realidade da ordem pública transnacional na pratica arbitral, in Revista do Direito do Comércio e das Relações Internacionais, v. 1, n. 1, 1989, p. 67.
} 
Por isso, a execução dos contratos comerciais internacionais está sujeita a graus distintos de limitação em razão de ordem pública. Em primeiro lugar, estão sujeitas à ordem pública interna daquele determinado Estado. O Regulamento (EC) 593/2008 do Parlamento Europeu e do Coselho Europeu, que converteu a Convenção de Roma de 1980 sobre a lei aplicável às obrigações contratuais em direito comunitário europeu, estabelece que "a escolha pelas partes de uma lei estrangeira, acompanhada ou não da escolha de um tribunal estrangeiro, não pode, sempre que todos os outros elementos da situação se localizem num único país no momento dessa escolha, prejudicar a aplicação das disposições não derrogáveis por acordo, nos termos da lei desse país, e que a seguir se denominam por 'disposições imperativas",

O mesmo regulamento estabelece que devem ser aplicadas também as leis de aplicação necessária ou lois de police, ou seja, a escolha do direito aplicável não pode "prejudicar a aplicação das regras do país do foro que regulem imperativamente o caso concreto, independentemente da lei aplicável ao contrato".

Além disso, o contrato também está sujeito a uma ordem pública internacional, estreitamente vinculada ao direito internacional privado, que "impede e condiciona: (i) a aplicação do direito estrangeiro; (ii) o reconhecimento dos atos praticados, das declarações de vontade de fatos ocorridos no exterior; e (iii) a execução de sentenças proferidas por tribunais estrangeiros" ${ }^{\prime 617}$. Note-se que esta noção, relacionada à análise da nova lex mercatoria, tem relevância na execução de laudos arbitrais proferidos em outro Estado, recordando-se que de maneira geral não é permitida a escolha de regras de direito anacionais como lei aplicável em tribunais estatais.

Especificamente em relação às arbitragens comerciais internacionais, vale mencionar que os árbitros não estão vinculados a nenhum Estado específico, não lhes sendo imposta uma ordem pública nacional ou estatal determinada, sem prejuízo, porém, da incidência das leis de aplicação necessária do foro onde a arbitragem é conduzida. De acordo com LALIVE, com base na ordem pública transnacional, os árbitros podem dar preferência à ordem pública de um determinado Estado em

\footnotetext{
${ }^{616}$ B. GoldMAN, Nouvelles reflexions sur la lex mercatoria, in Festschrift Pierre Lalive, Basel, Frankfurt a.M., 1993, p. 251, adota uma posição mais restrita, de certa maneira limitando a ordem pública estatal. GOLDMAN aponta que "il est fort douteux que la faculté puisse en être reconnue à l'arbitre, par application analogique de l'article 7 de la Convention de Rome du 19 juin 1980, car ce serait nier la transnationalité du contrat en cause. Pas davantage nous ne pensons qu'un arbitre soit tenu d'appliquer la loi de police d'un Etat, sauf si cette loi revêt un caractère d'ordre public transnational, ou véritablement international; mais dans ce cas, elle correspondrait à l'ordre public de la lex mercatoria, et serait de toute manière applicable au titre de la compétence de celle-ci".

${ }^{617}$ M. BASSO, Curso de direito internacional privado..., p. 267.
} 
detrimento da de outro ${ }^{618}$. Não obstante, o tribunal arbitral deve fazer o máximo para que sua decisão não contrarie a ordem pública do(s) Estado(s) em que o laudo pode vir a ser executado ${ }^{619}$.

As partes de um contrato comercial internacional em que a lex mercatoria é aplicável, e o árbitro que decida uma controvérsia dele decorrente, estão ademais sujeitos a uma ordem pública internacional. O código de processo civil francês, em seu artigo 1502, por exemplo, estabelece que é possível recorrer do laudo arbitral se, entre outras razões, "si la reconnaissance ou l'exécution sont contraires à l'ordre public international".

A ordem pública internacional reflete o jus cogens, é expressão dos valores de maneira geral compartilhados pela comunidade internacional ${ }^{620}$. O artigo 53 da Convenção de Viena sobre Direito dos Tratados estabelece que "uma norma imperativa de Direito Internacional geral é uma norma aceita e reconhecida pela comunidade internacional dos Estados como um todo, como norma da qual nenhuma derrogação é permitida e que só pode ser modificada por norma ulterior de Direito Internacional geral da mesma natureza".

A ordem pública internacional abrange também a ordem pública própria do comércio internacional $^{621}$, ou seja, compreende a ordem pública transnacional ${ }^{622}$ a que está sujeita a nova lex mercatoria ${ }^{623}$.

Segundo OSMAN, a nova lex mercatoria, em sua produção normativa, deve contribuir, por reciprocidade e cooperação, ao respeito das regras produzidas pelas ordens públicas das outras ordens jurídicas, em contrapartida ao fato de que as ordens jurídicas estatais e interestatais devem contribuir, quando necessário, em caso de excecução dos laudos arbitrais. É neste contexto que OSMAN identifica a existência de 'un corps de principes, qui constituent le sommet de la pyramide des normes 'mercatiques' ainsi que son noyau dur.... Nous y voyons, par analogie aus ordres

\footnotetext{
${ }^{618}$ P. Lalive, Ordre Public Transnational..., pp. 52-3.

${ }^{619}$ O artigo 35 do Regulamento de Arbitragem da Câmara de Comércio Internacional (CCI) estabelece que "em todos os casos não expressamente previstos no presente Regulamento, a Corte e o Tribunal Arbitral deverão proceder em conformidade com o espírito do presente Regulamento, fazendo o possível para assegurar que a decisão seja executável perante a lei".

${ }_{620}$ M. J. BONELL, Un “codice” internazionale ..., pp. 237-8.

${ }^{621}$ I. STRENGER, Direito do Comércio..., p. 139.

${ }^{622}$ Alguns autores, como F. OSMAN, Les príncipes généraux..., a denominam de ordem pública anacional.

${ }^{623}$ B. GOLDMAN, The applicable law..., p. 115.
} 
juridiques étatiques - ordre publique -, et interétatique - jus cogens -, la preuve de l'emergénce d'un ordre publique anational",624.

A ordem pública da nova lex mercatoria é formada pelos princípios gerais de direito $^{625}$, esculpidos no artigo 38 do estatuto da Corte Internacional de Justiça ${ }^{626}$, e pelos princípios gerais específicos do novo ius mercatorum ${ }^{627}$.

Além das decisões arbitrais e por vezes judiciais, a ordem pública transnacional é também afirmada por normas informais, pela própria classe mercantil, como é exemplo os códigos de boas práticas publicados por grandes grupos empresariais ${ }^{628}$. É também o caso das diretrizes e boas práticas publicadas pela Organização para a Cooperação e Desenvolvimento Econômico (OCDE) ${ }^{629}$.

São anuláveis, por violarem a ordem pública, os contratos de corrupção - que podem ser de mandato, comissão ou em outro formato. Também o são contratos que coloquem em risco ou envolvam transferência ilícita de bens culturais e patrimônio comum da humanidade, com base no famoso caso Plateau des Pyramides. Assim também aqueles relacionados a tráfico de drogas, tráfico de armas, seqüestros, assissantos ou que violem embargos decorrentes de sanções econômicas e direitos humanos $^{630}$.

Segundo LALIVE, "no direito internacional privado da arbitragem existe princípio geral que obriga o árbitro a respeitar as legítimas expectativas das partes, tais como emergem do contrato em conformidade com a missão a ele confiada". O jurista jurista suíço, mencionando uma decisão da Suprema Corte dos EUA (Mitsubishi v. Solar), que reputa necessária "sensibilidade à necessidade do sistema comercial internacional da previsibilidade na resolução de litígios", conclui que "a previsibilidade $^{631}$ é, indubitavelmente, um valor fundamental neste campo..."632. Por

\footnotetext{
${ }^{624} \mathrm{~F}$. OSMAN, Les príncipes généraux..., 456.

${ }^{625}$ P. KAHN, Les principes généraux..., p. 307, afirma que "il est vrai, les principes généraux du droit expriment un ordre public transnational fondamental auquel les parties ne peuve porter atteinte".

${ }^{626}$ F. MARRELLA, La nuova lex mercatoria..., p. 712.

${ }^{627}$. B. GOLDMAN, The applicable law..., p. 115.

${ }^{628}$ E. LoQuin, Où en est la lex mercatoria..., p. 31.

${ }^{629}$ Vide $h t t p: / / w w w . o e c d . o r g / p u b l i c a t i o n s / 0,3353$, en_2649_201185_1_1_1_1_1,00.html.

${ }^{630}$ E. LOQUIN, Où en est la lex mercatoria..., p. 49, P. KAHN, Les principes généraux..., pp. 314 e ss., e P. LaLIVE, Ordre Public Transnational..., pp. 36 e ss.

${ }^{631}$ A previsibilidade reflete a proteção à expectativa legítima das partes. Isto é, é legítima na medida em que não contraria a ordem pública transnacional.

${ }^{632}$ P. Lalive, Ordre Public Transnational..., pp. 52-3.
} 
isso, "deveriam existir comparativamente poucas oportunidades para o árbitro internacional recorrer ao conceito de ordem pública transnacional"633.

Também KAHN sustenta que a intervenção dos árbitros em nome de ordem pública, embora possa ser alargada, deve se limitar ao essencial, suficiente para "assumer la cohésion et la cohérence d'un système dans des circonstances exceptionelles de façon à ne pas faire de milieux d'affaires des sociétés fermées, indifférentes" $" 634$. FRIGNANI ressalta que "si registra infatti una tendenza a dare alla nozione di ordine pubblico... un significato restrittivo: l'eccezione è stata assai raramente accolta e quelle poche volte il vizio invocato poteva avere un'altra qualificazione" ${ }^{, 635}$.

A intervenção dos árbitros em nome da ordem pública transnacional ou internacional é um valioso instrumento para imprimir coerência à nova lex mercatoria $\mathrm{e}$ compatibilizar sua existência e desenvolvimento com outros valores da sociedade que não econômicos. Mesmo assim, essa intervenção deve ser interpretada de maneira restritiva e fundamentada em valor protegido pela ordem internacional.

${ }^{633}$ P. Lalive, Ordre Public Transnational..., p. 25.

${ }^{634} \mathrm{P}$. KAHN, Les principes généraux..., p. 318.

${ }^{635}$ A. FRIGNANI, L'arbitrato commerciale internazionale..., p. 270. 


\section{REFLEXÃO CRÍTICA SOBRE A LEX MERCATORIA NA SOCIEDADE PÓS-INDUSTRIAL: DESAFIOS E LIMITES}

\subsection{Críticas à nova lex mercatoria}

O capítulo anterior buscou descrever e analisar a nova lex mercatoria retomando aspectos históricos de seu aparecimento e identificando seus agentes, fontes e conteúdo. Cabe, então, indagar as dificuldades com as quais a nova lex mercatoria se depara.

As críticas à nova lex mercatoria são recorrentemente relacionadas à indefinição ou escassez de seu conteúdo, e conseqüente imprevisibilidade de suas soluções, na ajuridicidade de suas regras e na impossibilidade de caracterizá-la como ordenamento jurídico. De maneira geral, este último tipo de crítica se funda na incompletude de seu conteúdo; na ausência de uma autoridade central e na inexistência de sanções próprias a tal ordem jurídica e em outros argumentos fundados no Estado, bem como na inexistência da societas mercatorum ou na impossibilidade da individualização dos sujeitos que a compõem.

Após quase meio século de debates a respeito, é fundamental recordar que algumas dessas questões suscitadas, altamente controversas ao longo das últimas décadas, passaram a ser - ao menos na prática - de menor interesse do que outras questões mais recentes.

GAILLARD afirmou que o debate sobre a nova lex mercatoria suscitou reações apaixonadas dos mercatoristas e antimercatoristas ${ }^{636}$. Entretanto, para esse autor, "it would be a mistake ... to consider that the debate has gone around in circles, always dwelling on the same issues. On the contrary, it has been strongly renewed. Initially, the controversy focused on the very existence of rules other than those found in a given legal system.... Among practitioners, this initial controversy was for a time so inflamed that the positions taken seemed to be driven more by act of faith than by rational argument. These positions were all the more futile when, at the same time, the players of international commerce were already making full use of their options by selecting, where appropriate, transnational rules to govern their contracts" ${ }^{637}$.

\footnotetext{
${ }^{636}$ E. GAILLARD, Trente ans de lex mercatoria..., p. 6.

${ }^{637}$ E. GAILlARD, Transnational Law - A Legal System or a Method of Decision Making?, in Arbitration International, v. 17, n. 1, 2001, p. 60.
} 
Segundo GAILlARD, a nova lex mercatoria (ou as regras transnacionais), independentemente de sua forma, já está suficientemente assentada para que a discussão se concentre na forma de estabelecimento mais detalhado de seu conteúdo ou em método para fazê-lo de forma mais sistemática ${ }^{638}$.

Mais do que questões em relação a seu conteúdo, os principais desafios e limites da nova lex mercatoria dizem respeito à sua relação com as demais ordens jurídicas e compatibilização ou harmonização com outros interesses que não econômicos. É assim essencial iniciar uma reflexão sobre a relação da nova lex mercatoria com o Estado e a ordem internacional e, principalmente, com interesses que extrapolam a esfera puramente contratual e individual.

Mesmo assim, ainda que de forma breve, é bastante valioso para o fim a que se propõe este trabalho repassar os vários tipos de crítica à nova lex mercatoria, inclusive aquelas cujo interesse prático possa ser secundário.

\subsubsection{A nova lex mercatoria teria conteúdo vago, incerto e insuficiente e sua aplicação resultado imprevisível}

Uma das objeções mais comuns à nova lex mercatoria é aquela que indaga sua viabilidade e efeitos práticos em razão de um conteúdo que seria insuficiente e também em contante formação e transformação e, por isso, pouco conhecido.

Sendo de natureza prática, tal questionamento é expressado também por alguns advogados. DEZALAY e GARTH relatam que "um advogado especialista em arbitragem, de um grande escritório em Paris, afirmou que a lex mercatoria pode ser sujeita a abuso quando o árbitro não quiser escolher uma lei nacional ou quando decidir que alguma coisa é lex mercatoria porque é uma resposta que o árbitro considera certa. A questão é se as partes comerciantes sentem que proporciona segurança e previsibilidade suficientes"639. Um outro advogado afirmou que uma das razões pelas quais "as counsel

\footnotetext{
${ }^{638}$ E. GAILlARD, Transnational law..., p. 60. Segundo o jurista francês (p. 61), a discussão principal seria se a nova lex mercatoria é definida por seu conteúdo ou fontes.

${ }^{639}$ Y. DeZAlay; B. GARTh, Merchants of law..., p. 40. Segundo M. Mustill, The New Lex Mercatoria - The First Twenty-five Years, in Arbitration International, 1988, pp. 86 e ss., cf. disponível [on-line] in www.trans-lex.org/126900 [15.12.2009], “...one may take stock of the lex mercatoria as it stands today by asking. Does it provide the businessman with a set of rules which is sufficiently accessible and certain to permit the efficient conduct of his transactions? Is the lex manifestly superior, in its content and methodology, to establish national systems of commercial law? If so, is its superiority so obvious that it can now be said to have imposed itself, whether by the very fact of its existence or by a notion of implied consent, on the international business community as a whole, and on all transactions in which it is not expressly excluded? In short, has the lex mercatoria stolen the international commercial scene, pushing
} 
I would not rely on principles of international law: Advising clients to use these principles might imply my responsibility, since the predictability of their application is low. In negotiations, one tends not to innovate too much. Negotiating with another party by invoking these principles requires that the other party is as well assisted by somebody who is aware of these principles and knows how to handle them. This is not always the case"

MANN, por sua vez, afirmou, a respeito da nova lex mercatoria como meio de superar o método da localização de conflitos, "it is difficult to imagine a more dangerous, more undesirable and more ill-founded view which denies any measure of predictability and certainty and confers upon the parties to an international commercial contract or their arbitrators powers that no system of law permits and no court could exercise", 641 .

Segundo GIARDINA, além de favorecer os mais fortes, a nova lex mercatoria "conduce a dei resultati incerti ed insicuri che contraddicono alla base quelle esigenze di prevedibilità e di stabilità dei rapporti e delle soluzioni che sono comunemente ritenute fondamentali per l'ordinato svolgimento e lo sviluppo del commercio e degli investimenti internazionali, ${ }^{642}$.

BONELL também afirma que "in assenza di una definizione sufficientemente precisa della natura e dei contenuti di tali principi generali di diritto o della ipotetica lex mercatoria, una scelta del genere rischia di dar luogo ad una situazione di incertezza e imprevidibilità ancora maggiori" ${ }^{643}$.

Como já observado, a previsibilidade, que reflete as legítimas expectativas das partes - na medida em que não contrarie a ordem pública internacional -, é um valor fundamental no sistema comercial internacional ${ }^{644}$.

Segundo parte dos críticos da nova lex mercatoria, sua utilização como sistema jurídico ou conjunto de regras afetaria a previsibilidade principalmente por duas razões.

national laws into the wings? In each case, the detached observer must, I believe, be driven to answer 'no'. More sympathetically, he might add... at least not yet".

640 Cf. pesquisa realizada pela CENTRAL, disponível [on-line] in http://www.translex.org/output.php?docid=000003 [15.12.2009].

641 F. A. MANN, England rejects 'delocalized' contracts and arbitration, in International and Comparative Law Quarterly, 1984, v. 33, n. 1, p. 197.

642 A. GIARDINA, La lex mercatoria e la certezza del diritto nei commerci e negli investimenti internazionali, in Rivista di Diritto Internazionale Privato e Processuale, v. 28., n. 3, 1972, p. 463.

${ }^{643}$ M. J. BONELL, Un “codice” internazionale ..., p. 23.

${ }^{644}$ P. LALIVE, Ordre Public Transnational..., p. 25 e pp. 52-3. 
A primeira delas seria a imprecisão no recurso à nova lex mercatoria. Isto é, o novo ius mercatorum é aplicado quando há referência a princípios gerais de direito ou usos comerciais internacionais ou direito comercial internacional. O preâmbulo dos Princípios UNIDROIT - expressão da nova lex mercatoria ${ }^{645}$-, por exemplo, prevê que eles podem ser aplicados quando as partes tiverem escolhido os princípios gerais de direito, a nova lex mercatoria ou semelhante ${ }^{646}$.

As críticas são mais veementes ${ }^{647}$ quando os árbitros recorrem à nova lex mercatoria na ausência de escolha da lei aplicável pelas partes. Na edição de 2004 dos Princípios UNIDROIT acrescentou-se que eles poderiam ser aplicados "when the parties have not chosen any law to govern their contract" ${ }^{\prime 648}$. Ou seja, em que medida pode a decisão dos árbitros ser previsível se não se sabe quais regras de fundo os árbitros utilizarão para decidir a controvérsia. Ora, superar exatamente este tipo de problema, recorrente quando utilizado o método clássico de direito internacional privado ou de localização dos conflitos, não é um dos objetivos da nova lex mercatoria - como direito privado transnacional?

Nos comentários ao preâmbulo dos Princípios UNIDROIT, esclarece-se que esta possibilidade reflete a possibilidade de os árbitros aplicarem as regras de direito que julgarem mais apropriadas, como prevê o Regulamento de Arbitragem da CCI, por exemplo. Nesta hipótese, os árbitros podem entender que o silêncio das partes reflete o desejo das partes de excluir a aplicação de qualquer lei nacional ou quando um contrato for igualmente relacionado a diversas ordens jurídicas sem que nenhuma delas seja suficientemente predominante para que a aplicação de suas regras seja justificável ${ }^{649}$. Como já observado, o laudo CCI 7375/1996 qualificou a ausência de escolha das partes como um silêncio inquietante e, utilizando a ratio acima (teoria da escolha implícita

${ }^{645}$ Vide item 3.5.1.1.

646 Cf. disponível [on-line] in http://www.unidroit.org/english/principles/contracts/principles2004/integralversionprinciples2004-e.pdf (p. 1).

647 Vide, por exemplo, M. Mustill, The New Lex Mercatoria.... A. KASSIS, L'autonomie de l'arbitrage..., p. 422, por exemplo afirma que a utilização da teoria da vontade implícita negativa significa não serem aplicadas regras de direito. Conseqüentemente, o julgamento seria ex aequo et bono e, portanto, o laudo poderia ser impugnado.

648 Cf. disponível [on-line] in http://www.unidroit.org/english/principles/contracts/principles2004/integralversionprinciples2004-e.pdf (p. 1).

649 Cf. disponível [on-line] in http://www.unidroit.org/english/principles/contracts/principles2004/integralversionprinciples2004-e.pdf (pp. 4-5). 
negativa), decidiu por aplicar os Princípios UNIDROIT - na medida em que eles pudessem refletir "generally accepted principles and rules"650.

Note-se que a simples referência à nova lex mercatoria (ou as Princípios UNIDROIT) na ausência de referência expressa pelas partes não é suficiente para invalidar o laudo. Segundo Bonell, a única forma de impugnar tal decisão seria demonstrar que os árbitros agiram como amiable compositeurs, excedendo os limites dos respectivos mandatos. Ressalta porém, apoiado na decisão do Tribunal da Califórnia no caso The Ministry of Defense and Support for the Armed Forces of the Islamic Republic of Iran $v$. Cubic Defense Systems, que a probabilidade de êxito de tal argumentação está cada vez menor ${ }^{651}$.

Desde que limitada às hipóteses em que as partes efetivamente procuraram escapar do direito estatal do outro contratante ou de um terceiro direito, completamente estranho às partes, a aplicação da nova lex mercatoria em razão da teoria da escolha implícita negativa em vez de afetar a previsibilidade da decisão pode reafirmá-la, na medida em que afasta as partes das particularidades de cada um dos direitos nacionais ou não deixa ao arbítrio dos árbitros a escolha do direito aplicável ${ }^{652}$.

A segunda razão para que, segundo os críticos, a aplicação da nova lex mercatoria tenha resultado imprevisível e, portanto, indesejável, seria a vagueza, indefinição e escassez de seu conteúdo.

\footnotetext{
${ }^{650}$ Cf. disponível [on-line] in http://www.unilex.info/case.cfm?pid $=2 \&$ do $=$ case \&id $=625 \&$ step $=$ FullText [2. 9.2004]. Vide item 3.5.1.1.

${ }^{651}$ M. J. BONELL, The UNIDROIT Principles of International Commercial Contracts - The first 50..., pp. 75-7. M. J. BONELL, Un "codice" internazionale..., p. 229 "UNIDROIT Principles - a significant recognition by a United States Court", in Uniform Law Review, 1999, pp. 651 e ss. Vide item 3.5.1.1.

${ }^{652}$ Vide item 4.1.4 sobre os efeitos ao equilíbrio das partes e da decisão arbitral da utilização do direito de uma das partes ou de um dos árbitros e como a utilização de regras anacionais podem implicar menores custos de informação às partes. E. GAILlARD, Transnational law..., p. 70, afirma que "in actual practice, transnational principles are primarily used in three different situations. The first one occurs when the parties agree to the application of a given law, generally that of the State or the State-owned entity which is party to the transaction, but also agree to temper the application of that law by resorting to transnational rules of some sort. When dealing with a sovereign State, there is no doubt that the 'ordinary businessman' would favour transnational rules or, at a minimum, transnational rules tempering the laws of that sovereign State, over the laws of that sovereign State alone. The second situation arises when the parties could not agree on a given legal system, generally because of the perceived advantage that each party would obtain through the application of its own law, thus they selected transnational rules to govern their transaction. In such a situation, the predictability of the outcome is to be assessed in comparison with the parties' other option of remaining silent on the applicable law. Assuming that all potentially applicable laws would lead to the same result on a given issue, the question is likely to be moot but, should they diverge on the validity of a provision of the contract, for example, would it really be more predictable to leave the determination of its validity to the discretion of the arbitrators to select the applicable law, as opposed to accepting, through general principles, to have the contract governed by the rules which are, for any specific issue, the most generally accepted in the world? The third situation is precisely where the parties have remained silent as to the law applicable to their transaction. There, the reasoning is the same as the one which sometimes leads the parties to select transnational rules when they cannot agree on a given law".
} 
MAYER, por exemplo, afirma que "la lex mercatoria ne comporte qu'un nombre infime de règles précises en matière de théorie des obligations. Les usages, qui constituent sa partie la plus développée, sont presque toujours spécifiques à un type particulier d'opérations. A l'opposé, les principes généraux du droit ont un niveau de généralité tel qu'ils ne peuvent fournir directement la solution d'un litige" ${ }^{\text {653 }}$. Essa também é a opinião de MUSTILL ${ }^{654}$, LAGARDE ${ }^{655}$ e de KASSIS, que, por sua vez, afirma não serem os princípios gerais passíveis de resolver conflitos ${ }^{656}$.

Enfrentando esse tipo de argumento, BORTOLOTTI, ao analisar os contratos-tipo da Câmara de Comércio Internacional (CCI), anota que "as to the absence of precise (and foreseeable) rules, it is true that there is no established set of generally recognised principles of the lex mercatoria with respect to specific contracts and that there is consequently a certain risk of leaving too much discretion to the arbitrators. However, since the contract itself contains detailed rules which cover the most important issues, I do not think that the absence of precise rules on the remaining matters may be more dangerous that the recourse to domestic rules of one of the parties, which will often not be in line with the expectations of the other. And, as concerns more general contractual issues (formation, liability, etc.), the uncertainty can be substantially reduced by incorporating the Unidroit principles" ${ }^{\circ 57}$.

\footnotetext{
${ }^{653}$ P. MAYER, Le Principe de Bonne Foi..., p. 550.

${ }^{654}$ M. MustiLl, The New Lex Mercatoria..., após listar 20 princípios da nova lex mercatoria, salienta que "this list, incomplete as it may be, seems rather a modest haul for 25 years of international arbitration".

${ }^{655}$ P. LAGARDE, Approche critique..., p. 135.

${ }^{656}$ A. KASSIS, L'autonomie de l'arbitrage..., p. 405. A. KASsIS, Théorie générale des usages..., p. 549, afirma que a lex mercatoria comporta princípios contraditórios, como o pacta sunt servanda e rebús sic stantibus. Em verdade, não são contraditórios: um é regra e o outro é exceção. Segundo F. Marrella, La nuova lex mercatoria..., p. 712, n.r. 238, "Chiavi di volta dei due opposti principi [pacta sunt servana e rebus sic stantibus] è il principio di buona fede su cui convergono principi codificati, dottrina, prassi arbitrale e normativa, sia nazionale che internazionale". E. GAILLARD, Transnational law..., pp. 67-8 observa que "although general in scope, the binding force of contracts is by no means without exceptions. Just as an excessive penalty clause will be reduced or disregarded despite the pacta sunt servanda principle, a party cannot necessarily rely on a contract which has been dramatically rendered inoperable by unforeseen circumstances. Here the relationship is one of principle-exception, not one of principleapplication. Thus, the rebus sic stantibus rule, where applicable, will be construed narrowly, whereas the rule according to which the intent should override the letter or the contra preferentem rule can be expanded by analogy. All of the above rules operate within the general principles arena exactly as they would in the context of a given national law and therefore of a genuine legal order. In light of the above, it is not sustainable to argue that general principles are composed of vague and contradictory rules such as pacta sunt servanda and rebus sic stantibus. As we have seen, these two principles are not contradictory; they are interrelated in a principle-exception logic. Just like legal systems which recognize the imprévision rule frame it as an exception to the binding force of contracts, general principles can accept both, with one tempering the other".

${ }^{657}$ F. BORTOLOTTI, The ICC Model Contracts..., p. 88.
} 
Os Princípios UNIDROIT, como expressão da nova lex mercatoria, embora incompletos, de fato proporcionam mais clareza e transparência à nova lex mercatoria $\mathrm{e}$, conseqüentemente, aumentam a previsibilidade das decisões nela fundadas.

Note-se que uma boa parte das críticas dessa natureza à nova lex mercatoria foi formulada antes da publicação, difusão e solidificação na prática de meios muito relevantes de cognição e consolidação de princípios gerais da nova lex mercatoria, usos do comércio internacional e da jurisprudência arbitral. A criação de bases de dados online às quais não só os contratantes, mas também os árbitros podem ter acesso, tem um peso fundamental no aumento da transparência e previsibilidade da nova lex mercatoria. Segundo OSMAN, "le constat de l'existence d'instruments écrits de manifestation de la lex mercatoria rend le gried d'indétermination du contenu du droit anational infondé" 658 .

Assim, além dos Princípios UNIDROIT, a lista de princípios elaborada pelo Centro de Direito Transnacional (Center for Transnational Law - CENTRAL) ${ }^{659}$ é um

\footnotetext{
${ }^{658}$ F. OSMAN, Les príncipes généraux..., p. 308.

659 Vide trans-lex.org e http://www.trans-lex.org/browse.php?what=digest. Mesmo E. GAILLARD,
} Transnational law..., p. 65, reconhece que as listas, sejam os Princípios UNIDROIT ou os Princípios do CENTRAL, são de extrema importância, já que "these lists will in many instances, in the absence of any conflict or ambiguity, enormously facilitate the task of arbitrators having to rule on the basis of transnational rules". Segundo o jurista francês, porém, (pp. 62 e ss.) "however extensive they may be, these lists will never render the role of arbitrators dealing with general principles of law a mechanical", na medida em que não podem ser completas. Por isso, sugere uma outra abordagem para definir o conteúdo das regras transnacionais, com base não em uma lista, mas em um método de decisão, que consiste "in any given case, of deriving the substantive solution to the legal issue at hand not from a particular law selected by a traditional choice-of-law process, but from a comparative law analysis which will enable the arbitrators to apply the rule which is the most widely accepted, as opposed to a rule which may lie peculiar to a legal system or less widely recognized. The transnational law method should thus, in our opinion, be conducted in the following three steps. First, the utmost attention should be given to the parties' intentions. Second, the arbitrators will determine, on the basis of the comparative law sources mentioned above, whether the contentions made by the parties are supported by a widely accepted rule, or whether they merely reflect the idiosyncrasies of one legal system, in which case they should be rejected. Third, in determining whether the acceptance of a given rule is sufficiently wide for that rule to qualify as a general principle of law...". K. P. BERGER, The Concept of the "Creeping Codification"..., ao contrário, atribui mais vantagens ao método de listar e consolidar os princípios do que ao método sugerido por Gaillard, embora reconheça que um não exclui o outro, havendo uma contribuição cruzada entre os dois métodos. Segundo BERGER, o método de Gaillard não seria aceitável por duas razões. "First", Segundo Berger, "it underestimates the considerable problems that are related to the determination of the contents of the lex mercatoria. These problems were exemplified in the Eurotunnel arbitration. Gaillard maintains that it was the methodical task of the arbitrators in this case to ascertain the relevant jurisdictions from which the general principles, referred to in the complex choice of law clause of the construction contract, should be derived. In actual practice, however, the arbitrators decided to have recourse to the UNIDROIT Principles as a pre-fabricated set of rules of authoritative persuasiveness. Thus, the pragmatism of international arbitral practice lends itself much more to a collection of highly sophisticated rules and principles of transnational law than to the application of a transnational method of decision-making which requires 'access to a huge volume of comparative law studies'. Secondly, the idea of codifying the lex mercatoria through the drafting of lists on one side and the functional comparative methodology on the other do not constitute two antagonistic approaches to the same problem. It is true that the functional comparative method constitutes a topical approach that begins 
importante meio de cognição. Também a $\mathrm{CCI}^{660}$ e a Dispute Resolution Library da $\mathrm{CCI}^{661}$, o International Trading Centre UNCTAD/OMC ${ }^{662}$, UNILEX ${ }^{663}$, UNCITRAL $^{664}$, o Instituto de Direito Comercial Internacional da Universidade Pace ${ }^{665}$, Kluwer Arbitration ${ }^{666}$ e a Arbitration Database ${ }^{667}$ são fontes de cognição da maior importância.

Por outro lado, recorde-se também que, de fato, a nova lex mercatoria contém muito menos regras supletivas da vontade das partes do que os ordenamentos estatais, razão pela qual os princípios exercem um papel fundamental, principalmente o da boafé objetiva ou razoabilidade, que ocupa o lugar mais alto na hierarquia da nova lex mercatoria $^{668}$. Nesse contexto, é necessário que os princípios se concretizem ou especializem para que sejam eficazes ${ }^{669}$. Embora as listas ou compilações contribuam para tanto, tal tarefa é essencialmente realizada, no dia-a-dia, pelos árbitros ${ }^{670}$, de forma que alguns, como OSMAN, adjetivam a nova lex mercatoria como direito pretoriano ${ }^{671}$.

Independentemente de sê-lo ou não, fato é que a jurisprudência arbitral exerce um papel constitutivo em relação ao conteúdo da nova lex mercatoria. Como fonte desse novo ius mercatorum, os precedentes arbitrais são construção de longo prazo, a partir do julgamento de mais e mais demandas e da publicação dos laudos arbitrais, amplamente facilitada pelo acesso à internet .

with the analysis of an individual legal problem. It is, however, a particular characteristic of the lists that they allow to a far greater extent than domestic laws a topical approach to the finding of the law. It has already been emphasized in this study that it is one of the main tasks of scientific and practical research in the field of the lex mercatoria to avoid the creation of an inflexible, rigid and predetermined system that leaves no or only little room for the further development of this doctrine. This leads to a constant process of cross-fertilization between the decision-making work of international arbitral tribunals and the list. ...This means, that the lists are never 'completed' or 'closed'. Although in its initial form, a list may not contain the solution to a certain legal issue of transnational law, a later version may very well include a principle or rule that has been acknowledged in international arbitral or contract drafting practice".

${ }^{660}$ Vide www.iccwbo.org.

${ }^{661}$ Vide www.iccdrl.com.

${ }^{662}$ Vide www.jurisint.org.

${ }^{663}$ Vide www.unilex.info.

664 Vide http://www.uncitral.org/uncitral/en/case_law/digests/cisg.html. A UNCITRAL disponibiliza também uma base de dados sobre a Lei-Modelo de Arbitragem: http://www.uncitral.org/uncitral/en/case_law/thesauri.html.

${ }^{665}$ Vide www.cisg.law.pace.edu.

${ }^{666}$ Vide www.kluwerarbitration.com e kluwerarbitrationblog.com.

${ }^{667}$ Vide www.arbitration.fr.

${ }^{668}$ F. OSMAN, Les príncipes généraux..., p. 18.

${ }^{669}$ P. KAHN, Les principes généraux..., p. 319.

${ }^{670}$ Vide item 3.5.3.

${ }^{671}$ Segundo F. OSMAN, Les principes généraux..., p. 355, "les principes de la lex mercatoria sont en réalitè l'expression d'un droit prétorien, parce que l'autoritè qui les constate, qui est en même temps celle qui les crée, est l'arbitre". 
Assim, o conteúdo da nova lex mercatoria é hoje mais completo e transparente do que há uma década ou duas e a tendência é de sê-lo cada vez mais com o passar dos anos.

Vale, porém, uma ressalva em relação aos usos. Como já observado, o fato de os usos serem reduzidos a escrito não os descaracterizam, por si só, como uso ${ }^{672}$. Entretanto, não é viável que todos os usos seja reduzidos a escrito, sejam elencados ou identificados de forma geral. Primeiro, porque alguns devem ser mais adaptáveis - ou a menos sê-lo de forma mais rápida - do que outros. Segundo, porque poucos são os usos gerais como os princípios. Com algumas exceções, como por exemplo os INCOTERMS, os usos são circunscritos a um setor econômico, a um comércio, dando lugar em alguns casos à nova lex mercatoria setorial ${ }^{673}$. Nesses meios os usos são geralmente difundidos, conhecidos ou cognoscíveis ${ }^{674}$. Mesmo assim, aponta OSMAN, em um quadro em que os usos são heterogêneos e “en effet, même s'il n'y a pas une loi internationale générale des marchands, mais des usages très spécifiques, il existe entre les différents usages corporatifs des points de convergence suffisament solides pour conclure à une certaine unitè de l'ensemble"

Sob outra perspectiva, também interessante, LOQUIN afirma que as críticas em relação à pobreza do conteúdo da nova lex mercatoria circunscrevem-se à sua manifestação nos laudos arbitrais, não levando em conta que "la lex mercatoria s'est toujours nourrie des pratiques contractuelles en permanente évolution, mais aussi, et le phénomène est plus récent, du droit comparé" ${ }^{\prime 676}$.

De qualquer forma, não parece fundado o receio de que, freados os abusos, a utilização da nova lex mercatoria leve a resultados imprevisíveis. GAILLARD, que já atuou como árbitro em mais de 300 arbitragens internacionais, afirma que "contrary to

\footnotetext{
${ }^{672}$ Vide item 3.5.2 acima. A questão fundamental é garantir que os usos reflitam e sejam adequados às expectativas e práticas comerciais internacionais, que, muito dinâmicas, requerem um grau elevado de adaptabilidade e renovação desses usos. Para não se tornarem obsoletos ou defasados, requer-se, assim, que esses usos escritos possam ser revistos de forma periódica e célere para atender novas exigências impostas pela prática.

${ }^{673}$ Vide item 3.7.

${ }^{674}$ F. OSMAN, Les principes généraux..., p. 306, com base em J. Simon (Le commerce international des céréales, 1982).

${ }^{675}$ F. OSMAN, Les príncipes généraux..., p. 308.

${ }^{676}$ E. LoQUIN, Où en est la lex mercatoria?..., pp. 28 e ss. O autor menciona as euro-obligatoires, que existem graças à prática contratuais uniformes, afirmando que o mesmo raciocínio é aplicável a outros setores, como agrícola, comércio eletrônico. O jurista francês recorda também (p. 31) dos novos tipos de seguros e garantias (como as comfort letters e as garantias de first demand). Vide, a respeito desses novos tipos de garantia, H. LEGUILlONS (org.), As garantias bancárias nos contratos internacionais, trad. port. e anotações de L. O. BAPTISTA e J. A. T. GUERREIRO, São Paulo, Editora Saraiva, 1985, e M. BASSO, Contratos Comerciais do Comércio - Negociação, Conclusão, Prática, $2^{\mathrm{a}}$ ed., Porto Alegre, Livraria do Advogado, 1998.
} 
common wisdom, transnational rules offer as much predictability, if not more predictability, then genuine legal systems" ... críticas dessa natureza (sobre a insuficiência do conteúdo e imprevisibilidade de sua atuação) são, segundo o autor "based on a remarkably abstract perception of the law, totally detached from the realities of commercial transactions and the actual needs of "ordinary businessman" "677.

Segundo a pesquisa realizada pela CENTRAL, a alegada incompletude da nova lex mercatoria tem menor relevância prática do que a exeqüibilidade de um laudo arbitral. Além disso, os resultados da pesquisa revelaram que os efeitos da vagueza e incerteza relacionada à nova lex mercatoria são menos importantes do que a falta de experiência prática dos operadores, muitas vezes ocasionada pela falta de acesso às fontes da nova lex mercatoria ${ }^{678}$.

Este é um problema que, como se verá mais adiante, tende a ser relativizado, com a consolidação da nova lex mercatoria e maior acesso às suas fontes, de modo que os custos de informação com a escolha desse direito transnacional tendem a diminuir ${ }^{679}$.

\subsubsection{O conteúdo da nova lex mercatoria não seria jurídico}

A afirmação de que o conteúdo da nova lex mercatoria não seria jurídico é fundada em três tipos de argumento. O primeiro, de que o conteúdo é alguma coisa outra que não fonte do direito. O segundo, de que, ainda que fosse fonte do direito, nada mais seria do que fonte dos direitos nacionais e seu resultado nada mais seria do que direito comparado. Ou seja, o conteúdo da nova lex mercatoria não teria elementos que a diferenciem dos ordenamentos jurídicos estatais. Por fim, o terceiro consiste na inexistência da própria fonte ou conteúdo.

Para KASSIS, a nova lex mercatoria é um "accident de parcours dans l'histoire de la théorie du droit" 680 , sendo "un mythe qui a trop longtemps fourvoyé une bonne partie de la pensée juridique..."681.

\footnotetext{
${ }^{677}$ E. GAILLARD, Transnational law..., p. 70.

${ }^{678}$ Cf. disponível [on-line] in http://www.trans-lex.org/output.php?docid=000003 [15.12.2009]. M. R. FERRARESE, Le istituzioni della globalizzazione..., p. 175, com base em M. A. Eisenberg (The Nature of the Common Law, 1988), destaca, a respeito da common law - a que caracteriza como open ended, que " $\mathrm{i}$ principi istitzionali dell'adjudication fanno sì che 'il contenuto del diritto dipenda in parte da norme morali, da policies, da proposizioni di esperienza che hanno il requisito di un certo grado di consenso (support)'. In tal senso il common law è necessariamente incerto, anchorché ciò non significhi chi esso sia inconciliabile con la pianificazione e la prevedibilità, poiché ciò che è necessario per pianificare 'non è la certezza della regola, ma la fiducia nei risultati".

${ }^{679}$ F. MARRELLA, La nuova lex mercatoria tra controversie..., pp. 284-5.

${ }^{680}$ A. KASSIS, Théorie générale des usages du commerce..., p. 11.
} 


\subsubsection{Usos comerciais}

O primeiro questionamento em relação à juridicidade da nova lex mercatoria diz respeito às suas fontes (usos, princípios gerais e jurisprudência arbitral. Em relação aos usos, a objeção principal é a de que a existência de práticas contratuais não é suficiente para formação de uma regra jurídica.

Assim, segundo KASSIS, os usos comerciais não são regras de direito costumeiro, mas somente uso convencional. Isto é, uma prática repetida de tal forma no curso dos negócios que os contratantes não consideram mais necessário fazer referência expressa a ela, passando a ser sub-entendida. Os usos convencionais não têm, de acordo com KASSIS, o elemento psicológico necessário - a opinio necessitatis. "Cette caractéristique", observa aquele jurista, "marque la difference entre l'usage conventionnel qui n'est pas une règle de droit et la coutume qui est une régle de droit". Assim, tal qual no direito francês ou alemão, tratar-se-ia de questão de fato, de prova, não de direito ${ }^{682}$.

KASSIS apresenta duas outras objeções aos usos. Não podem ser caracterizados como fonte do direito já que as práticas da nova lex mercatoria não são obrigatórias, na medida em que as partes podem afastá-la por acordo expresso. Além disso, ainda que fossem considerados como direito costumeiro, não haveria nada que diferenciasse os usos do comércio internacional daqueles do comércio. Ainda que esses usos se formem à margem dos direitos estatais, não haveria "un trait distinctif des usages du commerce international",683.

\footnotetext{
${ }^{681}$ A. KASSIS, L'autonomie de l'arbitrage..., p. 423.

${ }^{682}$ A. KASSIS, L'autonomie de l'arbitrage..., pp. 396 e ss. O autor (pp. 397-8) afirma que "cette notion d'usage conventionnel différent d'une règle de droit coutumière est consacrée en France par ... l'article $1160 \mathrm{du}$ Code Civil, aux termes duquel 'on doit suppléer dans les conrats le clauses qui y sont d'usage, quoiqu'elles n'y soient point exprimées. Ce texte... voit dans l'usage... une clause contactuelle généralisée à un point tel que les contractants la considèrent comme évidente et n'éprouvent plus le besoin de l'expressément. Elle s'ajoute au contrat en tant que clause sous entendue, suppléée par une présomption de fait. Or une présomption de fait n'est pas une règle de droit, loin s'en faut. On trouve dans tous les systèmes juridiques étatiques cette notion d'usage conventionnel.... On la trouve en droit allemand sous le nom d'usages d'affaires ou d'usage du commerce (Verkehrssiten ou Handelsgebräuche) différents de la coutume (Gewohnheitsrecht). Elle est connue en droit anglais comme implied term". Também G. TEUBNER, 'Global Burkowina' - Legal Pluralism in the World Society, in G. TeuBNER, (org.), Global Law Without a State, Burlington, Ashgate, 2006, p. 9.p. 9, salienta que "no adequate conceptualization of opinio juris on the global level is provided". O jurista alemão (p. 17) conclui, assim, que a nova lex mercatoria "has nothing to do with customary law because empirical evidence shows that it is not based on practices nobilitated by opinion juris".

683 A. KASSIS, L'autonomie de l'arbitrage..., pp. 400-1.
} 
Assim também MustiLl, que afirma que "nobody could deny that usage ... can be an important element in the assessment by a tribunal of the rights and duties created by the contract, either because in a codified or inexplicit form it is tacitly incorporated into the contract, or because it has been received into the relevant national law. But there is nothing special about international trade in this respect, nor anything special about arbitration. Any worthwhile national court ought to be capable of taking usage into account, without the need to accord to usage the status of a prime element in selfcontained system of law"684.

A nova lex mercatoria, como direito da sociedade pós-industrial, não requer grandes rupturas das formas jurídicas, até porque não pretende ser ordem jurídica exclusiva ou supra-nacional. Não requer a exclusão das ordens jurídicas estatais. Ao contrário, com elas co-existe. Mesmo porque o conteúdo da lex mercatoria não compreende determinadas matérias que são reguladas por direito nacional ou internacional. Nesse contexto, é importante reconhecer que a função dos contratos principal meio de formação dos usos - extrapola a esfera puramente bilateral, tendo efeitos coletivos e atuando, muitas vezes, como meio de transformações jurídicas. $\mathrm{O}$ contrato não deve ser, assim, concebido como mera aplicação do direito, mas como fonte do direito ${ }^{685}$.

Em seu interessante paralelo entre o direito internacional público e a nova lex mercatoria, PELLET recorda que "l'internationaliste de droit public ... n'éprouve aucune difficulté pour admettre qu'une pratique répétée qui en vient à être 'acceptée comme étant le droit' ... constitue une norme coutumière... et force est de reconnaître que les usages du commerce ... paraissent en tous points analogues à des coutumes internationales" ${ }^{686}$. Para o jurista francês, assim como no direito internacional público, "l'opinio juris des destinataires des normes et des juges ou des arbitres... ne fait pas doute: les uns et les autres ont le sentiment très vif qu'ils sont tenus de les respecter c'est la marque même du droit"687. Como já mencionado, PELlET afirma que "les contrats sont, à l'ordre mercatique, ce que les traités sont au droit international; et, à leur tour, les contrats contribuent à la formations des usages, come les traités à celle de la coutume" 688 .

\footnotetext{
${ }^{684}$ M. MustiLl, The New Lex Mercatoria...

${ }^{685}$ F. GALGANO, Lex mercatoria..., p. 232. Vide item 2.7.

${ }^{686}$ A. PELLET, La lex mercatoria "tiers ordre juridique"?..., pp. 66-7.

${ }^{687}$ A. PELLET, La lex mercatoria "tiers ordre juridique"?..., p. 67.

${ }^{688}$ A. PELLET, La lex mercatoria "tiers ordre juridique”?..., pp. 62-3.
} 
OSMAN é contrário à distinção entre usos convencionais e usos como regra de direito, porque, ao contrário do que sustenta Kassis, não reflete a inserção dos usos na nova lex mercatoria e não reflete as características da maioria dos sistemas jurídicos ${ }^{689}$. De acordo com OSMAN, "les usages anationaux revêtent, en effet, un caractère juridique. Ils se distinguent donc nettement des pratiques d'affaire..." ${ }^{690}$. E a distinção, para o jurista francês, está justamente na existência da opinio iuris. Em sua ausência, "l'usage a la valeur d'une 'règle' interpretative de la volonté des parties et tire sa force exclusivement de cette dernière".

É possível observar que, de certa forma, o ponto de discórdia entre Kassis e Osman reside na possibilidade de as práticas contratuais do comércio internacional serem dotadas de opinio iuris, isto é, de haver consciência dos destinatários de estarem juridicamente vinculados a elas ${ }^{691}$. A questão, sob esta perspectiva, passa necessariamente pela discussão a respeito da (in-)existência da societas mercatorum, que será objeto de análise a seguir. De qualquer forma, OSMAN conclui pela "existence incontestable d'un réseau dense d'interactions et de rétroaction entre pratique, règle écrite e jurisprudence" suficientes para caracterizar a opinio iuris ${ }^{692}$.

Segundo GALGANO, a opinio iuris resultaria da aplicação das práticas contratuais pelas câmaras arbitrais na convicção de que devem ser aplicadas ${ }^{693}$.

KONRADI e FIX-FIERRO, sob uma perspectiva mais prática do que teórica, também afirmam a juridicidade dos usos. Para eles, "trade usages should be considered as a part of the lex mercatoria... it is a fact that contracts, arbitral awards and codified commercial law, all open the door to the actual practices of merchants as a source of standards of decision and interpretation"694.

A controvérsia sobre a juridicidade dos usos parece ter menos interesse prático do que teórico. De fato, na prática, os usos têm sido considerados como regras jurídicas

\footnotetext{
${ }^{689}$ F. OSMAN, Les príncipes généraux..., p. 429. O autor complementa que "même dans les ordres juridiques qui la consacrent, elle semble être un recul, qu'il s'agisse de faire l'application d'usages du commerce interne ou international". Segundo OSMAN (pp. 416-7), a distinção entre usos convencionais e usos como regra de direito, pela Cour de Cassation, existe por questões meramente utilitárias. Para ele, a Cour de Cassation tem dificuldades em tratar de forma uniforme um direito em mutação constante, perpétua.

${ }^{690}$ F. OSMAN, Les príncipes généraux..., p. 429.

${ }^{691}$ No mesmo sentido, F. Galgano, La globalizzazione ..., p. 60, afirma que "l'opinio iuris atque necessitatis... non è l'ubbidienza ad una superire autorità, che qui non esiste, ma è il rispetto, da parte di ciascun operatore economico, di ciò che gli altri operatori economici si ritengono legitimati ad attendersi da lui, quantunque si tratti di doveri non imposti dal contratto".

${ }^{692}$ F. OSMAN, Les príncipes généraux..., p. 298.

${ }^{693}$ F. Galgano, La globalizzazione ..., p. 76.

${ }^{694}$ W. KONRADI; H. FIX-FIERRO, Lex mercatoria in the mirror ..., p. 209, n. 5.
} 
e fontes da nova lex mercatoria por juízes e árbitros em disputas internacionais ${ }^{695}$. E a distinção entre os usos de direito interno e direito transnacional é dada pela prática contratual, doméstica ou internacional, do meio ou comércio em que se forma (como por exemplo, comércio internacional de grãos ou de açúcar).

Além disso, a opinio iuris - a consciência, pelos destinatários, de estarem juridicamente vinculados a uma prática - parece ser fundada e resultar da própria necessidade de previsibilidade, basilar ao comércio internacional. Ou seja, havendo repetição e generalidade ${ }^{696}$ de determinada prática, desde que compatível com a boa-fé objetiva, pela interação entre os operadores, as regras escritas e a jurisprudência, passa a existir a expectativa legítima ou previsibilidade razoável de vinculação dessa prática. Ou seja, torna-se uso e constitui regra jurídica e fonte da nova lex mercatoria. É esse o tratamento previsto, por exemplo, no artigo $9^{\circ}$ da CISG e 1.9 dos Princípios UNIDROIT $^{697}$.

\subsubsection{Princípios gerais}

Assim como os usos, os princípios gerais também são questionados como fonte da nova lex mercatoria, não porque seus enunciados não consistiriam em princípios ou em regras jurídicas, mas porque não seriam transnacionais.

Nesse sentido, KASSIS afirma que “à y regarder de près, les règles que l'on cite comme principe de la lex mercatoria son tout principes que l'on rencontre dans les différents droits nationaux. Porquoi donc en faire des principes spécifiques de la lex mercatoria au lieu d'y voir des principes commun aux droits nationaux?"698.

\footnotetext{
${ }^{695}$ Vide item 3.5.3. F. OSMAN, Les príncipes généraux..., p. 295, afirma "qu'au delà des fluctuations terminologiques, les arbitres ne distingue aucunement pratiques et usages, en tant que sources formelles distinctes de la lex mercatoria".

${ }^{696}$ Recorde-se que o termo generalidade comporta elasticidade e, tratando-se de usos, adquire contornos distintos, na medida em que os usos muitas vezes estão circunscritos a um determinado setor econômico.

${ }^{697}$ Art. $9^{\circ}$ CISG: (1) The parties are bound by any usage to which they have agreed and by any practices which they have established between themselves. (2) The parties are considered... to have impliedly made applicable to their contract or its formation a usage of which the parties knew or ought to have known and which in international trade is widely known to, and regularly observed by, parties to contracts of the type involved in the particular trade concerned. Art. 1.9 dos Princípios UNIDROIT (1) The parties are bound by any usage to which they have agreed and by any practices which they have established between themselves. (2) The parties are bound by a usage that is widely known to and regularly observed in international trade by parties in the particular trade concerned except where the application of such a usage would be unreasonable.

${ }_{698}$ A. KASSIS, L'autonomie de l'arbitrage..., p. 390. KASSIS (pp. 425-37) dedica algumas páginas para criticar o método sugerido por Gaillard (vide n.r. 659 acima), afirmando (p. 426) que, com ele, "la lex mercatoria est réduite à une simple méthode qui n'a rien de spécifique, elle est ravalée à une banale analyse de droit comparé...".
} 
Como já observado, embora fundada no direito comparado, a utilização ou recepção de um princípio como princípio da nova lex mercatoria decorre não em razão de pertencer a um ou outro sistema jurídico, mas sim pelo fato de ter caráter transnacional - que decorre, não de seu universalismo, mas de sua adaptação às necessidades do comércio internacional ${ }^{699}$.

Ou seja, ao se tornarem princípios da nova lex mercatoria, observa KAHN, os princípios têm como âmbito de aplicação não vinculado a um território específico na esfera do comércio internacional. Os árbitros transformam, simplificam, destacam o princípio do(s) respectivo(s) ordenamento(s) nacional(is), permitindo sua transnacionalização ${ }^{700}$.

Às colocações de Loquin e Kahn, KASSIS apresenta a objeção de que, se assim for, caberia a pergunta se seria possível a esta sociedade (dos mercadores) não tomar consciência dessas regras estatais comuns aos sistemas jurídicos, sendo inconcebível que pudessem desafiá-las. Além disso, KASSIS não vê como e onde há a transformação ou transnacionalização do princípio. Afirma que "il est donc illogique que les principes généraux du droit communs aux systèmes nationaux puissent être conçus comme des règles anationale". Além disso, não se tornariam princípios em razão de um número reduzido de laudos arbitrais ${ }^{701}$.

A prática parece, porém, não refletir a opinião de Kassis. A prática arbitral tem demonstrado como os princípios da nova lex mercatoria, evidenciados ou enunciados por ocasião da solução de um determinado litígio, adquirem um sentido distinto daquele atribuído por uma determinada ordem jurídica. Seu conteúdo não se reduz ou equipara, assim, a uma mera síntese ou resultado de direito comparado. Basta analisar o histórico dos trabalhos dos Princípios UNIDROIT e seu resultado final ${ }^{702}$ ou, por exemplo, o conteúdo da boa-fé no comércio internacional ${ }^{703}$ ou o desenvolvimento do dever de minimizar os danos ou hardship ${ }^{704}$.

Observe-se que são fonte da nova lex mercatoria tanto os princípios gerais de direito, tal como previstos no artigo 38 do estatuto da Corte Internacional de Justiça, e

\footnotetext{
${ }^{699}$ F. OSMAN, Les príncipes généraux..., 354 e E. LOQUIN, Où en est la lex mercatoria?..., pp. 37-9. Vide item 351.

${ }^{700}$ P. KAHN, Les principes généraux..., pp. 326-7.

${ }^{701}$ A. KASSIS, L'autonomie de l'arbitrage..., pp. 403-4.

${ }^{702}$ Vide item 3.5.1.1 e M. J. BonELL, Un “codice” internazionale.., pp. 27 e ss.

${ }^{703}$ Vide item 3.5.1.3.

${ }^{704}$ P. KAHN, Les principes généraux..., p. 322 e ss. Vide também F. GALGANO, La globalizzazione ..., pp. 64 e ss.
} 
os princípios específicos do comércio internacional ${ }^{705}$. Por isso, a crítica de LAGARDE de que não seria admissível que os princípios de direito internacional passem para nova lex mercatoria por um tipo de osmose $\mathrm{e}^{706}$. São princípios distintos, com funções distintas, como torna evidente a análise da ordem pública internacional e da ordem pública transnacional $^{707}$.

\subsubsection{Jurisprudência arbitral}

A atividade dos árbitros é fundamental para o desenvolvimento e sedimentação da nova lex mercatoria, na medida em que os laudos reconhecem, enunciam princípios e usos aplicáveis e servem de referência para casos futuros. Entretanto, questiona-se se essa atividade constitui jurisprudência e, portanto, é fonte normativa.

KASSIS afirma enfaticamente que "la jurisprudence arbitral internationale est un mythe" ${ }^{\text {708 }}$. Para o jurista francês, o simples fato de que os laudos arbitrais fazem, de forma regular, referência a precedentes de outros laudos proferidos em situações análogas não é suficiente para caracterizar a jurisprudência arbitral como fonte de direito. Isto porque "une jurisprudence est l'apanage d'une justice obligatoire e organisée, investie d'un pouvoir institutionnel", não ficando sua existência a cargo da boa vontade de particulares. Para tanto, seria necessário uma hierarquia e uma corte suprema que assegure a unidade da jurisprudência ${ }^{709}$.

Segundo KASSIS, não seria correto afirmar que, embora tal hierarquia e corte suprema não existam, a arbitragem tem um centro - a CCI. Primeiro, porque tal "centro" não seria em nada comparável com a estrutura judicial das ordens estatais, capazes de garantir a unidade da jurisprudência. Para ele, mesmo que fosse comparável, a CCI não é toda a arbitragem comercial internacional. E, mesmo assim, nada autorizaria afirmar que os laudos arbitrais se distinguiriam por um grau elevado de coerência.

Para TEUBNER, além do problema da hierarquia, os laudos arbitrais são de certa forma episódicos e as câmaras arbitrais são deficientes em comunicar uns com os

\footnotetext{
${ }^{705}$ Vide item 3.5.1.

${ }^{706}$ P. LAGARDE, Approche critique..., p. 131.

707 Vide item 3.7.

708 A. KASSIS, L'autonomie de l'arbitrage..., p. 404. Vide também Théorie générale des usages du commerce..., pp. 501-18.

${ }^{709}$ A. KASSIS, L'autonomie de l'arbitrage..., p. 43.
} 
$\operatorname{outros}^{710}$. Também MuSTILL aponta que, não só a maioria dos laudos não é publicada, como aqueles laudos que vêm à luz são, quase sem exceção, relacionados à aplicação de leis nacionais. Segundo o jurista britânico, um número muito menor do que o aclamado pelos mercatoristas realmente diz respeito à nova lex mercatoria ${ }^{711}$.

MAYER, por sua vez, ao advertir sobre os perigos da utilização do princípio da boa-fé na nova lex mercatoria, compara a jurisprudência arbitral com aquela das instituições estatais, observando naquela um problema de coerência e envergadura em razão da inexistência de um centro regulador. Mas o jurista francês vai além. Segundo ele, 'en l'absence d'une cour régulatrice, et compte tenu de la culture juridique hétérogène des arbitres: chacun a tendance à donner à la lex mercatoria un contenu proche des solutions de son propre droit national", o que resultaria "pour les parties une insécurité particulièrement grande, à laquelle peut même succéder, la sentence une fois rendue, une impression d'arbitraire" ${ }^{\text {712 }}$.

OSMAN, ao contrário, aponta que os árbitros, na ausência de legislador internacional apto a reger as relações comerciais internacionais, exercem uma função

\footnotetext{
${ }^{710}$ G. TEUBNER, 'Global Burkowina'..., p. 20.

${ }^{711}$ M. MustiLl, The New Lex Mercatoria... Segundo MustiLl, "although the number cited is rather greater, the present author believes that not more than about 25 are really concerned with it. Furthermore, as more than one author has pointed out, the selection for publication is made, quite legitimately, to illuminate some aspect of the doctrine. The practitioner has no way of finding out whether there have been other awards in which the application of the lex mercatoria was raised and rejected, or never raised at all". Segundo um levantamento de F. DASSER, Lex Mercatoria..., pp. 2-4, aponta que, baseado em uma amostra de publicações entre 1989-99, foram 34 os laudos que utilizaram somente regras anacionais, dos quais 18 foram escolhidos pelos árbitros (sendo 4 com base em amiable composition), 13 pelas partes (sendo 3 em conjunto com amiable composition), 6 por escolha implícita. O autor levantou 20 laudos que utilizaram regras não estatais combinadas com direito nacional. O relatório estatístico de 2008 da CCI verificou que, em 2008, 84\% dos contratos que deram causa a disputas continha escolha expressa de lei nacional. Em 3\% dos casos, as partes escolheram regras anacionais, como a CISG (mais freqüente), os Princípios UNIDROIT. Apenas em alguns poucos contratos havia referência à nova lex mercatoria por meio da aplicação do direito internacional, direito internacional comercial, princípios gerais universalmente reconhecidos. Em 2007, segundo o relatório daquele ano, foram 3 contratos, um se referindo à CISG, outro aos Princípios UNIDROIT e outro às regras da Organization for the Harmonization of Business Law in Africa (OHADA). Em 2006, 2\% dos quase 600 casos, sendo que metade deles com referência à CISG, alguns da outra metade se referiram ao direito internacional comercial, princípios gerais universalmente reconhecidos. A base de dados da Unilex informa que já são ao menos 215 decisões que fazem referência aos Princípios UNIDROIT cf. disponível [on-line] in http://www.unilex.info/dynasite.cfm?dssid=2377\&dsmid=13618\&x=I [28-11-2009].. A análise dos números deve ser feita em conjunto com o fato que a nova lex mercatoria é utilizada muitas vezes como filtro cultural, em conjunto com direito nacional. A base de dados da Unilex dá notícia de 112 decisões, 59 das quais laudos arbitrais, que utilizam os Princípios UNIDROIT para interpretar ou suplementar o direito nacional aplicável, cf. don-line] isponível in http://www.unilex.info/dynasite.cfm?dssid=2377\&dsmid=13621\&x=1 [4.1.2009]. Por fim, deve-se levar em conta que a lex mercatoria não se reduz somente à arbitragem, mas também se expressa na elaboração de instrumentos uniformes para o comércio internacional.

${ }^{712}$ P. MAYER, Le Principe de Bonne Foi..., p., 549. Embora, segundo citação de F. OsMAN, Les príncipes généraux..., p. 314, a opinião expressada por MAYER (L'autonomie de l'arbitre dans l'appréciation de as propre compétence, 1989) seria outra.
} 
normativa justificando sua atividade em certa medida criadora ou inventiva em relação aos princípios $^{713}$.

Já STRENGER afirma que as decisões dos tribunais arbitrais como fontes da nova lex mercatoria "têm sido verdadeiros guias de sentenças posteriores, transformando-se, com as permanentes publicações, em autênticos repositórios jurisprudenciais, pois a jurisprudência, como é concebida, não se constitui em apanágio do Estado" ${ }^{\text {714 }}$. Com efeito, o laudo CCI 4131/1982 anotou que as decisões dos tribunais arbitrais formam progressivamente uma jurisprudência, moldada pelas necessidades do comércio internacional $^{715}$ - necessidades essas que dão origem à opinio iuris, para a formação da qual, aliás, o papel da jurisprudência arbitral é essencial ${ }^{716}$.

Segundo FRIGNANI, não só existe tal jurisprudência arbitral, na medida em que "ben raramente ci si discosta da una serie costante di precedenti arbitrali, se non per dire che essi non si applicano al caso concreto o che essi sono contrari ad una norma specifica (nazionale) da applicarsi nel caso concreto", como ela é fonte constitutiva da nova lex mercatoria ${ }^{717}$. Esta posição é reforçada principalmente em razão da crescente publicidade dos laudos e facilidade de acesso a seu conteúdo em razão da criação de bases de dados on-line e outros meios de publicação $^{718}$.

Ademais, as críticas de que não haveria como garantir que os precedentes sejam adotados ou não sejam desconsiderados sem motivo, ou mesmo que o laudo poderia soar até arbitrário em razão de cada árbitro tender atribuir à nova lex mercatoria conteúdo próximo a seu próprio direito nacional, não se sustentam na prática.

Primeiro, pela própria necessidade de previsibilidade. Considerando-se que (i) os árbitros são nomeados pelas próprias partes, (ii) o meio arbitral é pequeno e fechado, em que a reputação tem um grande valor ${ }^{719}$, (iii) os árbitros são remunerados para atuarem nas disputas, não é razoável admitir que, houvesse uma divergência gritante dos precedentes ou uma distorção indevida da nova lex mercatoria, (iv) os agentes do

\footnotetext{
${ }_{713}$ F. OSMAN, Les príncipes généraux..., p. 321.

${ }^{714}$ I. STRENGER, Direito do Comércio..., p. 133.

${ }^{715}$ Vide item 3.5.3 acima.

${ }^{716}$ F. Galgano, La globalizzazione ..., p. 76. F. Osman, Les príncipes généraux..., p. 412, observa que "le besoins du commerce international confèrent par conséquent une plus grande assise et légitimité aux solutions retenues par l'arbitre ... l'arbitrage doit tendre à une previsibilité des solutions susceptible d'être retenues lors d'un différend. Cela signifie que l'effet relatif de la chose jugée doit s'effacer devant les nécessités d'unifier de telles solutions, afin de répondre aux besoins de la communauté internationale de commerçants... Ce sont les besoins du commerce international qui confèrent sa raison d'être à l'activité de production normative des arbitres et, par suite, à l'apparition d'une jurisprudence arbitrale".

717 A. FRIGNANI, L'arbitrato commerciale internazionale..., p. 160.

718 Vide item 3.5.3.

${ }^{719}$ Y. DEZALAY; B. GARTH, Merchants of law..., pp. 36 e ss.
} 
comércio internacional, principalmente as empresas transnacionais, estariam satisfeitos com o resultado da arbitragem, (v) e, portanto, continuariam a nomear ou recomendar os mesmos árbitros, (vi) e que os árbitros de maneira generalizada correriam o risco de descrédito, perda de reputação e de fonte de renda ${ }^{720}$, (vii) aproximadamente $80 \%$ dos contratos internacionais conteriam cláusula arbitral e, por fim, não seria razoável admitir que (viii) entre $80-90 \%$ dos laudos fossem executados espontaneamente ${ }^{721}$.

Aliás, é justamente para garantir a previsibilidade do laudo, afastando as especificidades e tecnicidades dos direitos nacionais, que os árbitros utilizam a nova lex mercatoria, em especial os Princípios UNIDROIT, como filtro cultural ${ }^{722}$.

Já as críticas fundadas na inexistência de autoridade e institucionalização dos órgãos de arbitragem são moldadas na organização estatal, que não é o único, e não levam em conta certas características do direito na sociedade pós-industrial, como pluralismo jurídico, o papel das autoridades privadas ou a função do contrato. Esses argumentos serão levados em conta no item a seguir.

\subsubsection{A nova lex mercatoria não constituiria ordenamento jurídico}

É recorrente a crítica de que a nova lex mercatoria não constitui ordenamento jurídico autônomo. A rigor, da inexistência da nova lex mercatoria como ordem jurídica própria decorrem críticas que, apenas para facilitar a compreensão, foram elencadas em itens acima. LAGARDE, por exemplo, afirma que a existência de um tal conjunto de regras, com princípios gerais próprios, somente pode ser reconhecida se admitida sua caracterização como ordem jurídica ${ }^{723}$.

\footnotetext{
${ }^{720}$ F. MARRELLA, La nuova lex mercatoria tra controversie..., pp. 274-5, pontua que "se il giudice togato è un funzionario dello Stato, l'arbitro è vincolato alle parti da uno specifico rapporto, un contratto di arbitrato. All'inamovibilità del giudice ordinario ed ai necessari vincoli che ne fanno un organo del potere giurisdizionale dello Sato, si contrappongono la mobilità e la precarietà del ruolo dell'arbitro, un soggeto privato che viene abilitato a decidere solo per volontà delle stesse parti in funzione della propria reputazione, reputazione sottoposta a continua verifica arbitrato dopo arbitrato, decisione dopo decisione. ... La fiducia, regola d'oro degli operatori del commercio internazionale, diviene fondamento dell'attività del rendere giustizia, un'attività che diviene un servizio valutabile alla stregua di criteri di mercato".

${ }^{721}$ É claro que deve haver casos em que, embora a parte envolvida na arbitragem quisesse questionar o laudo arbitral, ela não o faz em razão do custo-benefício, seja porque os custos e tempo envolvidos seriam altos ou porque haveria sanções se o fizesse. Mas, mesmo assim, parece difícil crer que a porcentagem de execução espontânea dos laudos diminuísse drasticamente.

${ }^{722}$ Vide item 3.5.1.1.

${ }^{723}$ P. LAGARDE, Approche critique..., p. 131.
} 


\subsubsection{A incompletude da nova lex mercatoria}

As objeções à caracterização da nova lex mercatoria são de ordens distintas. Argumenta-se, por exemplo, que a nova lex mercatoria não constitui ordenamento jurídico porque suas regras não têm conteúdo jurídico e, se o tiver, não é conteúdo próprio ou mesmo suficiente. KASSIS afirma, como relatado acima, que os usos, os princípios gerais e a jurisprudência arbitral não são fontes normativas. Além disso, sustenta o jurista francês, a tese da lex mercatoria como ordem jurídica autônoma encontra dificuldade também no fato de que não é, ou não é ainda, completa, na medida em que não regula certas matérias, como vício de consentimento ou capacidade das $\operatorname{partes}^{724}$.

GOLDMAN reconhece que a lex mercatoria não é - ao menos por ora ${ }^{725}-$ completa, não regulando questões como as indicadas acima, mas não considera tal fato impeditivo à caracterização da nova lex mercatoria como ordenamento jurídico ${ }^{726}$. Essa também é a opinião de STRENGER ${ }^{727}$. BOBBio, em sua teoria do ordenamento jurídico, assim como KERCHOVE e OST, salienta que a necessidade da completude da ordem

\footnotetext{
${ }^{724}$ A. KAssis, L'autonomie de l'arbitrage..., p. 406. M. MustiLl, The New Lex Mercatoria ..., ressalta que "the lex mercatoria has not yet laid claim to the whole territory of potential disputes arising from international commerce. Thus: (i) there appears to be no instance in which the lex has been invoked in a case of pure delict: (ii) the left has rarely been applied where the issues are those of consent, fraud in the making of a contract, and so on; (iii) the left has not, as far as the present author is aware, ever been credited in the literature with a power to create rights to rem, valid as against third parties - for example, by way of a transfer of title of corporeal assets, or pledge, or the creation of a monopoly such as patent or copyright".

${ }^{725}$ M. J. Bonell, Un "codice" internazionale.., p. 41, relata, por exemplo, que a edição de 2004 implicou também extrapolar, de certa maneira, a relação puramente contratual, de natureza bipolar. Isto porque foram objeto do novo projeto as relações tripartites, como o agenciamento e a cessão, e também matérias tradicionalmente reguladas por normas cogentes, como prescrição. A terceira edição, em desenvolvimento, incluirá os seguintes temas: efeitos da extinção de contrato não cumprido, ilegalidade, pluralidade de credores e devedores, condições e resolução de contratos de longo prazo por justa causa, cf. disponível [on-line] in http://www.unidroit.org/english/workprogramme/study050/main.htm [28.11.2009]. Pode ser um indicativo de caminhos adicionais a serem percorridos pela nova lex mercatoria.

${ }^{726}$ B. Goldman, Nouvelles reflexions..., pp. 248-9. E. GaIlLARD, Transnational law..., pp. 66 e ss, ao contrário, afirma que um dos elementos necessários para a caracterização de uma ordem jurídica é sua completude, entendida como a capacidade de prover resposta a qualquer questão jurídica surgida entre as partes, mesmo que seja necessário recorrer a princípios gerais de direito. Ao lado da completude, são elementos que caracterizam uma verdadeira ordem jurídica seu caráter estrutural (composto de regras organizadas e inter-relacionadas em graus distintos de generalidade, como, por exemplo, a boa-fé), sua capacidade de desenvolvimento (para fazer frente às necessidades da sociedade à qual suas regras se destinam) e previsibilidade. Afirma que a lex mercatoria, baseada no método por ele sugerido (vide n.r. 659 acima), é ordem jurídica completa. A afirmação de Gaillard resulta em algumas dificuldades. A nova lex mercatoria não se pretende suficiente e, ao menos atualmente, não regula algumas questões, tais como capacidade das partes, vício de consentimento, entre outras.

${ }^{727}$ I. STRENGER, Direito do Comércio..., p. 124: "a lex mercatoria é um processo e, ainda que não seja um ordenamento jurídico completo, fatalmente chegará a sê-lo".
} 
jurídica para que seja reconhecida teria como conseqüência o reconhecimento de que o direito não tem lacunas ${ }^{728}$, o que é infundado - tanto em teoria (já que o direito, como expressão social, deve mudar, se adaptar), quanto na prática, como lembra FARALLI. GOLDMAN questiona, então, assim como FRIGNANI $^{729}$, se, mesmo sendo incompleto, o direito internacional público não é também ordem jurídica ${ }^{730}$.

VIRALLY aponta que a natureza das transações comerciais multiplicam os vínculos de pertencimento a uma determinada ordem jurídica, de modo que se torna difícil ou mesmo impossível submetê-la a uma só ordem jurídica. Assim, conclui o internacionalista francês, “un ordre juridique n'est pas nécessariement complet e totalement auto-suffisant. C'est le cas de l'ordre juridique international qui, pour um certain nombre de problèmes, est obligè de renvoyer leur solution aux droits internes" $" 731$.

FERRARESE destaca que a incompletude não é característica exclusiva só da nova lex mercatoria. Para a socióloga do direito italiano, seria "il segno di un cammino ancora incompiuto sulla strada della giuridicità appare invece un tratto che segna un po' tutto il diritto, sia esso nazionale, internazionale, sovranazionale o transnazionale, se pure in forme e consistenze diverse" ${ }^{, 732}$.

\subsubsection{O problema da autoridade, sanções e outros argumentos fundados no}

\section{Estado}

Sob outra perspectiva, a nova lex mercatoria também não poderia, sustenta-se, constituir ordem jurídica autônoma na medida em que não se funda em uma autoridade central. Não tem jurisdição própria, na medida em que não se funda em um território. Não teria, portanto, sistema próprio de sanções, na medida em que deve recorrer ao Estado. Este tipo de argumento, que assume várias formas e desdobramento, se calca em

\footnotetext{
${ }^{728}$ N. BobBiO, Teoria dell'ordinamento giuridico..., pp. 115 e ss e M. V. D. KeRChOve, F. OsT, Legal system between order and disorder, New York, Oxford, 1994, p. 53. C. FARALLI, Certezza del diritto..., p. 91 e pp. 101 e ss. destaca que a sociedade atual é caracterizada pela insegurança e instabilidade em razão das rápidas transformações, da enorme mobilidade e da contínua diversificação de grupos sociais, que não compartilham de valores comuns e têm interesses distintos. Novas relações econômicas surgem e demanam novos institutos e relações jurídicas de modo a intensificar o papel criador do juiz. Este fato, somado à proliferação de legislação especial e de normas regulamentares, torna difícil atribuir ao direito um caráter de certeza, afetando os alicerces da noção de segurança.

${ }^{729}$ A. FRIGNANI, L'arbitrato commerciale internazionale..., pp. 138-9.

${ }^{730}$ B. GOLDMAN, Nouvelles reflexions..., p. 250.

${ }^{731}$ M. VIRALLY, Un tiers droit?..., pp. 377-8.

732 M. R. FERRARESE, Diritto sconfinato..., p. 101.
} 
uma abordagem monista do direito, tendo por pressuposto a necessária origem estatal, direta ou indireta, para que uma regra possa ser jurídica. Ou seja, sustenta-se que, ainda que existisse, o novo ius mercatorum só existiria por autorização dos Estados. Isto é, em última instância, esse direito comercial internacional estaria fundado nos Estados. Para MARrella, essas críticas seriam as "dogmático-estatais".

KASSIS afirma que o problema das sanções constitui o calcanhar de Aquiles da nova lex mercatoria na medida em que "la sanction est l'élément nécessaire pour qu'il y ait une règle de droit, et si la lex mercatoria est faite de règles de droit, pour qu'elle soit effectivement appliquée, une condition supplementaire est requise: cella de la sanction". A inexistência de sanções é, para KASSIS, suficiente para afastar a juridicidade dessas regras, já que é a sanção distingue uma regra jurídica da moral. "Sans la contrainte sociale", sustenta o jurista francês, "il n'y a pas de norme juridique”. Para ele, os organismos profissionais da societas mercatorum não poderiam - como sugerido por GOLDMAN $^{733}$ - ser caracterizados como autoridade porque os contratos-tipo, os usos codificados e as condições gerais e outros instrumentos são soft law e não regras imperativas. Dessa forma, a intervenção da força pública de um Estado é necessária, condição de sua existência - o que, em último grau, demonstraria que a nova lex mercatoria não só não tem sanções próprias, como também não tem jurisdição própria. Por isso, conclui KASSIS, se assim fosse e existisse uma lex mercatoria, "elle n'aurait alors plus aucune spécificité, elle ferait partie du droit étatique et de l'ordre juridique étatique, elle ne serait et ne saurait être 'un droit anational', un ordre juridique autonome, distinct des ordres juridiques étatiques" ${ }^{\$ 734}$.

No antigo ius mercatorum, inexistente o Estado moderno, as guildas impunham multas, suspensões, e exclusão e os mercadores estavam também sujeitos à falência e à perda de reputação ${ }^{735}$.

O direito canônico, fruto da ordem jurídica da Igreja Católica, também tem sanções próprias que não são fundadas no Estado, como a excomunhão e, ao menos no passado, a recusa do enterro cristão ${ }^{736}$, sem que tal suscite resistência equivalente à imposta à nova lex mercatoria sobre sua juridicidade ou a caracterização como ordenamento jurídico.

\footnotetext{
${ }^{733}$ B. Goldman, Frontières..., p. 190.

${ }^{734}$ A. KASSIS, L'autonomie de l'arbitrage..., pp. 408-12.

735 A. C. CuTLER, Private Power..., pp. 124 e 136.

736 A. C. Cutler, Private Power..., p. 124. Vide também A. Pellet, La lex mercatoria "tiers ordre juridique”?..., p. 72.
} 
A analogia entre a nova lex mercatoria e o direito internacional público é, mais uma vez, muito útil. Comenta VIRALly que a definição do direito pela previsão de sanção resulta em sérias dificuldades sob a perspectiva do direito internacional, na medida em que "la seule conclusion logique qui s'impose est que le droit international n'est pas du droit"737 ou não constitui ordem jurídica própria.

Nesse sentido, PEllet enfatiza que, assim como o direito das gentes, a lex mercatoria "repose sur des mécanismes de sanction imparfaits...", afirmando que, em certa medida pelo menos, os mecanismos de coação desse direito transnacional é "sans doute moins aléatoires que ceux dont le droit international est doté" ${ }^{738}$.

De fato, as sanções de que dispõe a nova lex mercatoria têm natureza distinta daquelas existentes nos ordenamentos jurídicos estatais, mas isso não faz com que percam tal natureza, ainda que sejam imperfeitas. São, como aponta, MARRELLA, market based sanctions ${ }^{739}$, sanções específicas e complementares àquelas previstas na ordem jurídica estatal.

MARRELlA elenca como sanções específicas da nova lex mercatoria a reprovação ou juízo negativo (biasimo); difusão da notícia de não execução espontânea do laudo entre os membros da business community; a contratação em condições mais onerosas - como, por exemplo, pedido de garantias maiores ou condições diversas de pagamento que inviabilizem a permanência do inadimplente no mercado ${ }^{740}$; boicote privado, que pode atingir um ou mais Estados; não admissão em uma associação ou entidade profissional ou outra organização não governamental; exclusão de uma associação ou entidade profissional; além de sanções pecuniárias impostas pelas entidades profissionais $^{741}$. Existe também a possibilidade de suspensão da qualidade de membro, a vedação de utilizar no futuro determinada instituição $\operatorname{arbitral}^{742}$ ou de vedação à participação de concorrências ${ }^{743}$.

\footnotetext{
${ }_{737}^{737}$ M. VIRALLY, Un tiers droit?..., p. 375.

738 A. PELlET, La lex mercatoria "tiers ordre juridique”?..., pp. 59 e 73. Vide também A. FRIGNANI, L'arbitrato commerciale internazionale..., p. 162.

${ }^{739}$ F. MARRELLA, La nuova lex mercatoria tra controversie..., p. 259. B. GoldMAN, Frontières..., pp. 191-2, cunhou parte dessas sanções como sanções morais com implicações profissionais e econômicas.

${ }^{740}$ A. FRIGNANI, L'arbitrato commerciale internazionale..., p. 162.

${ }^{741}$ F. MARRELLA, La nuova lex mercatoria tra controversie..., pp. 270-2. Em relação ao último tipo de sanção, MARRELLA relata que "è il caso, ad esempio, della International Air Transport Association (Iata), ove l'osservanza delle regole astatuali stabilite nel quadro delle 'conferenze di traffico' viene sistematicamente controllata da ispettori privati inviati dall'associazione medesima nella sedi delle compagnie aeree associate ed in caso di violazione sono comminate delle penali pecuniarie particolarmente elevate".

${ }^{742}$ I. STRENGER, Direito do Comércio..., p. 131.

743 A. FRIGNANI, L'arbitrato commerciale internazionale..., p. 162.
} 
A título exemplificativo, é interessante o resultado do estudo empírico de KONRADI e FIX-FIERRO sobre os mecanismos sociais de produção e execução de normas da indústria madeireira na Alemanha. Com base em questionários feitos às madeireiras internacionais operando na Alemanha, os autores constataram a existência dos seguintes mecanismos: divulgação de informação, incluindo circulação de lista negra de empresas estrangeiras que não cumpriram contratos ou laudos arbitrais; substituição de uma transação fracassada por uma com sucesso, com base na autorização do contrato-tipo da associação que permite o vendedor a revender as mercadorias em caso de descumprimento; exclusão do membro da própria associação; e, por fim, arbitragem intra-indústria, cujas decisões tem precisado ser executadas em um tribunal estatal apenas em casos muito excepcionais ${ }^{744}$.

FRIGNANI recorda que, além dessas sanções indiretas, as cláusulas penais, as garantias contratuais e os seguros já compõem um sistema sancionatório próprio dos $\operatorname{contratos}^{745}$.

Segundo MARRELA, a efetividade da nova lex mercatoria consiste em um market based contract enforcement ${ }^{746}$. E, como observa FRIGNANI, o que é essencial a uma regra jurídica é sua aplicação se as partes não a excluem ou a ela nãp renunciam e não, contrario sensu, o fato de ser imperativa, de não poder ser afastada pelas partes ${ }^{747}$. Complementa FRIGNANi que uma norma é efetiva pelo reconhecimento por parte de seus destinatários e não em razão de sua promulgação pela autoridade do Estado ${ }^{748}$.

Tanto a maioria dos contratos como a maioria dos laudos arbitrais são executados espontaneamente. Em relação aos primeiros, deve-se considerar o peso cultural das regras ${ }^{749}$ e também a existência de mecanismos antecipados que aumentam tal índice, como garantias, seguros e cláusulas penais ${ }^{750}$.

\footnotetext{
${ }^{744}$ W. KONRADI; H. FIX-FIERRO, Lex mercatoria in the mirror..., pp. 223-4. Vide também os relatos de L. BERnSTEIn, Opting out of the Legal System..., pp. 115 e ss., e Private commercial law in the cotton industry..., pp. 1724 e ss.

745 A. FRIGNANI, L'arbitrato commerciale internazionale..., p. 162.

${ }^{746}$ F. MARRELLA, La nuova lex mercatoria tra controversie..., p. 272.

747 A. FRIGNANI, L'arbitrato commerciale internazionale..., p. 161.

748 A. FRIGNANI, L'arbitrato commerciale internazionale..., p. 161.

${ }^{749}$ M. R. FERRARESE, Le istituzioni della globalizzazione..., p. 67, que enfatiza uma cultura contratual, por parte das empresas, mais de cooperação do que do conflito, às vezes retardando a utilização de remédios contratuais e às vezes até renunciando a eles. I. STRENGER, Contratos Internacionais..., p. 80, comenta que "as partes ... não se preocupam somente com salvaguardar suas boas relações recíprocas, mas também de não se isolarem no meio negocial em que atuam, por exercício excessivamente detalhista de seus direitos, ou violação demasiado flagrante de suas obrigações. Essas diferentes características provocam enfraquecimento aparente do caráter jurídico, dos contratos em questão: afastamento dos direitos positivos, derrogações importantes a diversos princípios básicos do Direito das Obrigações, repugnância
} 
Já as soluções arbitrais, segundo GOLDMAN, não são realmente ignoradas no meio profissional a que elas dizem respeito ${ }^{751}$. Estima-se que o índice de execução espontânea dos laudos arbitrais seja de aproximadamente $80 \%$ a $90 \%{ }^{752}$.

Contribui também para um índice alto de aceitação das decisões arbitrais o fato de que, diferentemente dos juízes estatais, as partes nomeiam os árbitros. E a indicação dos árbitros, que consiste, na verdade, em contratação desses árbitros, leva em consideração alguns fatores. Primeiro, as partes podem - e normalmente o fazem nomear árbitros que, diferentemente dos juízes estatais, são especialistas em comércio internacional e/ou, por vezes, especialistas no setor econômico específico envolvido na disputa. Conta também a confiança e reputação, que é construída a longo prazo. Assim, a probabilidade de execução espontânea do laudo é maior do que no caso de sentenças proferidas nos tribunais nacionais ${ }^{753}$.

Além disso, acrescenta MARRELLA, a execução espontânea dos laudos arbitrais decorre, do ponto de vista da análise econômica do direito, da necessidade de minimizar os custos de reputação para manter o próprio posicionamento no mercado, custos estes que podem ser muito elevados como mostram as experiências jurídicas japonesa e chinesa $^{754}$.

Mesmo assim, "il recurso al braccio secolare dello Stato ed alle sue sanzioni non sminuisce il carattere di ordinamento giuridico della lex mercatoria ma, anzi, ne mette in evidenza il riconscimento ad opera dell'ordinamento tale.... Pertanto, attraverso il

em recorrer à via jurisdicional, mesmo à via arbitral, predominância dos aspectos técnicos, psicológicos e comerciais".

${ }^{750}$ V. FERRARI, Quesiti sociologici..., p. 9. W. KONRADI; H. FIX-FIERRO, Lex mercatoria in the mirror, p. 224, ressaltam que esses instrumentos são normalmente utilizados para novos participantes naquele comércio específico.

${ }^{751}$ B. GOLDMAN, Frontières..., p. 183.

${ }^{752}$ F. MARRELla, La nuova lex mercatoria..., p. 652 e Alcuni appunti..., p. 269 e I. STRENGER, Direito do Comércio..., p. 127, respectivamente. A. PELlET, La lex mercatoria "tiers ordre juridique”?..., p. 71.

${ }^{753}$ F. MARRELLA, La nuova lex mercatoria tra controversie..., pp. 273-5. O jurista italiano (p. 274) aponta também que, principalmente em relação a contratos de longo prazo (p. 275) "proprio in quanto l'arbitro risulta munito della bilancia e non della spada della giustizia si verificano le maggiori chances di pervenire ad una soluzione mutualmente accetabile, senza dover ricorrere all'ausilio della forza pubblica", o que alguns passam a questionar em razão da 'F. MARRELLA, La nuova lex mercatoria..., p. 125, americanização' da arbitragem, intensificação de seu caráter litigioso, bem como de sua formalização e procedimentalização. Além do próprio MARRELlA (p. 267), vide Y. DEZALAY e B. GARTH, Merchants of Law..., p. 29 e A. FRIGNANI, L'arbitrato commerciale internazionale..., pp. 292-3, que lamenta tal fato. Além disso, W. KONRADI; H. FIX-FIERRO, Lex mercatoria in the mirror..., p. 215, com base em F. Dasser (Internationale Schiedsgerichte und Lex Mercatoria, 1989), "such 'voluntary' compliance refers to those awards that, as a rule, are known to be enforceable. By contrast, it is to be doubted that the rate of compliance is as high when the losing party knows that the award cannot be enforced".

${ }^{754}$ F. MARRELLA, La nuova lex mercatoria tra controversie..., p. 273. Vide também A. SUPIOT, Homo Juridicus..., pp. 102-3. Se assim é em relação a laudos arbitrais, o ato de acatar outras penalidades privadas também deve estar sujeito a ponderações semelhantes. 
riconoscimento non si tramuta una norma da metagiuridica a giuridica bensì lo Stato aggiunge all'efficacia intrinseca propria dell diritto di tali ordinamenti un'ulteriore efficacia che è propria delle sue norme per conseguire gli effeti che sono propri a queste ultimi" ${ }^{755}$.

Dessa maneira, como recorda BOSCHIERO, críticas como a de Kassis refletem "un'idea doppiamente errata: in primis perchè misconosce l'esistenza di sanzioni specifiche nella lex mercatoria, ed in secondo luogo perchè muove dal principio per il quale una vera sanzione è solo quella che può accordare lo Stato",756. Além disso, é de se questionar a correção da definição do direito pela sanção ${ }^{757}$.

\subsubsection{A questão da societas mercatorum}

Uma terceira objeção à caracterização da nova lex mercatoria, ainda que se admita a possibilidade de um pluralismo jurídico, se baseia na inexistência da societas mercatorum, entendida como um conjunto de operadores do comércio internacional ligados por laços de solidariedade ${ }^{758}$. Ou seja, como salienta BosCHIERO, na inexistência "un gruppo sociale identificabile con sufficiente precisione, una società appunto nel senso istituzionale del termine, idonea a costituire (anche formalmente ed estrinsicamente) un'unità concreta, distinta dagli individui in essa compressi",759.

Segundo LAGARDE, Goldman e alguns outros mercatoristas, que atribuem à nova lex mercatoria o caráter de ordem jurídica, fazem - seja direta ou indiretamente, explicita ou implicitamente - referência à concepção institucional de ordem jurídica, freqüentemente àquela elaborada por Santi Romano.

\footnotetext{
755 F. MARrella, La nuova lex mercatoria..., p. 652. A. Pellet, La lex mercatoria "tiers ordre juridique"?..., p. 72, observa que "l'application du droit international dans son ensemble repose sur la bonne volonté des Etats; et il n'est pas jusqu'au droit communautaire qui ne dépende, por l'essentiel au moins, des Etats membres por sa mise en ouvre effective". O jurista francês afirma também que "il ne viendrait à l'espirit de personne de contester l'autonomie du droit italien par rapport au droit français au pretéxte que les jugements et arrêts rendus par les tribunaux de la Péninsule ne sont exécutoires en France que s'ils y ont obtenu l'exequatur d'un juge français". N. BOSCHIERO, La lex mercatoria nell'era della globalizzazione ..., p. 128, complementa que "in altre parole, nessun ordinamento può fare astrazione (se non in astratto) degli altro, e il fatto che ciascuno sia dotato di autonomia ed individualità non implica in alcun modo che non possoano o debbano venire tra loro in correlazione... ciò che si vuole sottolineare è che l'autonomia di una istituzione (ordem jurídica) non deve necessariamente essere assoluta... Degli altri ordinamenti bisogna tener conto nella misura in cui ad essi si fa richiamo per realizzare determinati fini". ${ }^{756}$ N. BOSCHIERO, La lex mercatoria nell'era della globalizzazione ..., p. 124.

${ }^{757}$ G. TEUBNER, 'Global Burkowina'..., p. 12, destaca que "'sanction' is losing the place it once held as the central concept for definition of law - for the delineation of the legal from the social and from the national". Vide também M. VIRALLY, Un tiers droit?..., pp. 374-5.

${ }^{758}$ Vide B. GOLDMAN, Frontières...

${ }^{759}$ N. BosCHIERO, La lex mercatoria nell'era della globalizzazione ..., p. 118.
} 
De acordo com SANTI RomANO, cuja concepção do direito é pluralista ${ }^{760}$, a instituição - um corpo social que é expressão da natureza social e não puramente individual do homem ${ }^{761}$ - é a manifestação por excelência originária e essencial do direito. O direito “ne peut se révéler qu'en une institution, et l'institution existe comme telle en tant que le droit la cré et et la mantient en vie"762.

Desse modo, relata LAGARDE, para os mercatoristas bastaria a constatação da existência da societas mercatorum (ou business community, mercatocracy, classe mercantil) para a caracterização da ordem jurídica ${ }^{763}$.

Segundo o jurista francês, a existência de normas não estatais não prova a existência de uma ordem jurídica mercantil. Ademais, sustenta, a comunidade de interesses que faz com que os agentes do comércio de grãos se agrupem em uma associação até pode ser origem de uma ordem jurídica de vocação limitada, mas tal ordem jurídica pode entrar em concorrência com uma associação rival com o mesmo objeto. Não há, para ele, relação orgânica necessária que pudesse fazer com que agentes do comércio de setores específicos se associem entre si. Além disso, mesmo que instituições de caráter geral tenham se desenvolvido ou se desenvolvam, não há como garantir que cada uma dessas instituições se considere como servidora ou órgão de uma ordem jurídica única de vocação geral ${ }^{764}$.

LAGARDE afirma ainda que o meio em que se desenvolve o comércio internacional é de tal maneira diversificado e fragmentado que se torna questionável a possibilidade de uma comunidade provida de um mínimo de organização nele se fundar. Inexiste, complementa o jurista francês, verdadeira organização do meio transnacional, estável, que não resulta automaticamente da existência de relações comerciais internacionais. LAGARDE então afirma que "ce soient seulement des îlots d'organisation

\footnotetext{
${ }^{760}$ S. RomAno, L'ordinamento giuridico, trad. franc. de Lucien François e Pierre Gothot, L'ordre juridique, $2^{\mathrm{a}}$ ed.,Paris, Dalloz, 2002, pp. 77 e ss.

${ }^{761}$ S. RomANo, L'ordinamento giuridico..., pp. 26 e ss. Segundo o jurista italiano (p. 28), "l'institution est une unitè stable et permanente, qui ne perd donc pas nécessairement son identitè à la suite de mutations intervenues dans tels ou tels de ses éléments: les personnes qui en font partie, son patrimoine, ses moyens". Mas, salienta F. OSMAN, Les príncipes généraux..., p. 409, "Santi Romano n'a... jamais défini l'institution comme une unitè organique, un tout formant un corps physisque".

${ }^{762}$ S. ROMANO, L'ordinamento giuridico..., p. 31. Segundo N. BOSCHIERO, La lex mercatoria nell'era della globalizzazione ..., p. 119, a ordem jurídica é assim como instrumento de auto-organização, autoinstitucionalização do corpo social, que realiza a própria unidade e identidade coletiva, dando expressão formal à própria ordem social.

${ }^{763}$ P. LAGARDE, Approche critique..., pp. 133-5. I. STRENGer, Direito do Comércio..., p. 135, afirma que, "com efeito, parece não haver discordância quanto ao fato de que uma vez organizada a 'societas mercatorum', implicitamente estaremos diante de uma ordem jurídica”.

${ }^{764}$ P. LAGARDE, Approche critique..., pp. 135 e ss.
} 
qui apparaissent dans le commerce international, non une organisation unique" e, portanto, que a nova lex mercatoria não pode ser caracterizada como ordem jurídica ${ }^{765}$.

Mesmo após as críticas de Lagarde, GOLDMAN afirma que a societas mercatorum existe, assim como existiu no mundo europeu da Idade Média, o que seria comprovado pela generalidade da aplicação dos princípios, regras e usos comerciais que formam a lex mercatoria, pois não seriam constatáveis se os usos tivessem valor separadamente dentro de uma das societates mercatorum parciais e restritas ${ }^{766}$.

Embora não rejeite a idéia da nova lex mercatoria e o pluralismo jurídico, TEUBNER também é contrário à concepção do ius mercatorum fundado na societas mercatorum, tal como sustentado por Goldman e outros mercatoristas. Segundo o jurista alemão, "they construe a droit corporatif of global economic actors, vaguely resembling medieval merchant law ... This institutionalist vision perceives a close-knit world community of merchants - a societas mercatorum - almost as a formal organization. For the competitive dynamics of today's world markets such a corporatism on the global scale seems somewhat antiquated, to put it mildly"767.

Para outros, como GIARDINA, mesmo que se admitisse sua existência, não seria possível se estabelecer ou individualizar com certeza suficiente quem pertence à societas mercatorum $^{768}$.

As objeções apresentadas por Lagarde, Teubner e Giardina sobre a existência da societas mercatorum levam a uma série de questões. A primeira delas se o caráter fragmentário do comércio internacional atual e a concorrência entre os atores impediriam a formação da societas mercatorum. Em seguida, e talvez mais importante, qual o fundamento desta sociedade, que une os comerciantes e faria com que sejam considerados seus membros. E, por fim, quem seriam seus os membros.

Em relação à primeira das questões, STRENGER anota que "o fato de não existir uma sociedade única dos comerciantes em decorrência das especializações comerciais não implica inexistir (a lex mercatoria); ... A existência de uma pluralidade de sociedades comerciais também não desvirtua a lex mercatoria porque o mesmo fenômeno se pode notar no regime estatal, que também necessita de leis especiais e dirigidas a certas comunidades" $" 769$.

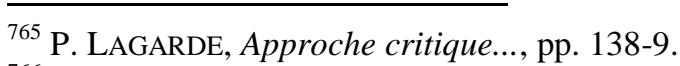

${ }^{766}$ B. GOLDMAN, Nouvelles reflexions..., p. 249.

${ }^{767}$ G. TEUBnER, 'Global Burkowina'..., p. 9.

768 A. GIARDINA, La lex mercatoria e la certezza..., p. 463.

${ }^{769}$ I. STRENGER, Direito do Comércio..., p. 126.
} 
Segundo PELLET, o fato de os atores transnacionais estarem em concorrência entre si não impede a formação da societas mercatorum e a caracterização da nova lex mercatoria como ordenamento jurídico. O jurista francês observa que esse fenômeno é comum a todas as coletividades humanas e complementa que "un ordre juridique n'est pas le signe d'une société consensuelle.... Il ne vise pas à une harmonie universelle et eternelle, mais à la coexistence d'inteérêts divergents aussi longtemps que cela est compativle avec l'évolution de leurs equilibres changeants". Além disso, complementa PELlET, as rivalidades, as oposições e iniqüidades entre os Estados não impede a formação da sociedade internacional e a existência da sociedade internacional. Ao contrário, "elles le rendent... particulièrment nécessaire",770.

Já em relação à segunda questão, KAHN enfatiza que a ordem da nova lex mercatoria, além da coerência externa para estabelecer sua originalidade e autonomia em relação às outras ordens jurídicas, deve manter também uma coerência interna para evitar a dispersão de seus componentes. Essa coerência interna é estabelecida "selon une méthode qui n'a rien de spécialement original, puisqu'elle consiste à mettre em place em résau de règles qui assure le fonctionnement de l'ensemble"771. MARRELLA vê na CCI um agente importante na aglomeração dos operadores e na unificação e disponibilização de regras e práticas para o comércio internacional ${ }^{772}$.

Note-se que, ao passo que aqueles que sustentam a sua existência parecem fazêlo com base em um argumento teleológico, as principais objeções à existência da societas mercatorum tendem a se basear em nas entidades individualmente consideradas e em uma realidade factual "física" fragmentada, o que para OSMAN seria equivocado $^{773}$. Como observado ${ }^{774}$, na sociedade pós-industrial, com a existência de espaços jurídicos, são criadas comunidades de interesse, que não necessariamente se baseiam em um mesmo espaço geográfico.

\footnotetext{
770 A. Pellet, La lex mercatoria "tiers ordre juridique”? ..., pp. 69-70. Vide também N. BosChIERO, La lex mercatoria nell'era della globalizzazione ..., p. 121, para quem o fato de haver concorrência entre seus membros e terem interesses divergentes não implica como conseqüência necessária a impossibilidade de considerá-la como corpo social. A autora italiana complementa que (p. 122) se não existisse um corpo único, homogêneo e etc, as críticas de que a business community é hegemônica e arbitrária não se sustentariam. Vide item 4.1.4.

${ }^{771}$ P. KAHN, Droit international économique, droit du developpement, lex mercatoria - concept unique ou pluralisme des ordres juridiques?, in Droit des relations economiques internationales - etudes offertes a Berthold Goldman, Paris, Litec, 1982, p. 100.

${ }_{772}$ F. MARRELLA, La nuova lex mercatoria..., p. 648.

${ }^{773}$ F. OSMAN, Les príncipes généraux..., p. 409, pontua que "l'erreur reside... dans ce que MM. Rigaux Lagarde assimilent chaque association professionnelle, chaque centre d'arbitrage à un corps unique formant un tout indivisible et ayant prétention à constituer une institution. Or, il ne s'agit nullement de cela, ces différents acteurs on les (voire des) éléments qui composent l'institution".

${ }^{774}$ Vide item 2.9.
} 
A coesão da societas mercatorum, independentemente da fragmentação do comércio e consequiente existência de sociedades específicas para um ou mais setores do comércio, baseia-se em "uma aglomeração geral de interesses subordinados em torno de inúmeros procedimentos operacionais, como é o caso da venda internacional, dos créditos documentários, dos Incoterms, das condições gerais de contratos, das garantias contratuais, etc."775.

De acordo com KAHN, diferentemente da ordem estatal e da ordem internacional, em que os laços de solidariedade estão baseados no interesse econômico, apenas de forma muito relativa e não essencial, 'l'ordre mercatique est la juridicité d'un corps social émietté qui n'a qu'un seul objectif, qui est son pôle d'attraction et sa seul responsabilité: 1'interêt economique"776. É em função de laços de interesses comuns geridos pelas entidades profissionais e pelas organizações não governamentais (CCI, principalmente), cuja função é de aglomerar os operadores a fim de unificar regras e práticas do comércio em vários setores atuantes em um espaço imaterial, transnacional, que BosCHIERO afirma ser difícil contestar a existência de um milieux fortemente homogêneo dos operadores do comércio internacional ${ }^{777}$.

Assim, a despeito da diversidade dos atores da nova lex mercatoria, OSMAN enfatiza que o caráter institucional, que embasa a societas mercatorum "provient de ce que tous les acteurs aspirent à une même fin, un idéal marchand unique: répondre aux besoins du commerce international". Ainda que sejam diferentes ou até mesmo concorrentes, as necessidades do comércio internacional são o denominador comum dos atores da nova lex mercatoria ${ }^{778}$.

Resta, assim, o exercício de individualizar quem forma a societas mercatorum.

Para GOLDMAN, os operadores do comércio internacional seriam as empresas e os Estados, quando praticarem atos de gestão- que concluem contratos que envolvam

\footnotetext{
${ }^{775}$ I. STRENGER, Direito do Comércio..., p. 126.

${ }^{776}$ P. KAHN, Droit international économique..., p. 99. KAHN (p. 100) afirma que o limite e fraqueza da nova lex mercatoria, como expressão da juridicidade da societas mercatorium, é o fato de ter como finalidade servir interesses de tipo econômico. A. C. CUTLER, Private Power..., pp. 185-6, com base em R. Cox (Critical Political Economy, 1995), reconhece, que a mercatocracia constitui uma força social transnacional baseada na consciência de uma preocupação comum de manter um sistema que possibilite àquela classe a manutenção de uma posição dominante. Efeitos negativos dessa natureza da nova lex mercatoria serão tratados nos próximos itens deste capítulo.

${ }^{777}$ N. BOSCHIERO, La lex mercatoria nell'era della globalizzazione ..., pp. 122-3. No mesmo sentido, E. LOQUIN, Où en est la lex mercatoria?..., pp. 26-7, afirma que "il existe un milieu fortement homogène de commerçants liés par des intérêts communs et organisés par des institutions ayant les moyens d'imposer des normes et de les faire sanctionner le plus souvent par l'intermédiaire d'un recours systématique à l'arbitrage".

${ }^{778}$ F. OSMAN, Les príncipes généraux..., p. 409.
} 
interesses do comércio internacional, as instituições privadas que participam de tal organização e os tribunais arbitrais ${ }^{779}$.

KAHN sugeriu, em 1961, uma sociedade de vendedores e compradores operando de forma habitual na esfera internacional, sem vínculo a um Estado específico ${ }^{780}$. Duas décadas depois, KAHN apontou que a ordem mercatique seria composta e elaborada pelas empresas que controlam as trocas internacionais ou as unidades de produção e pelas instituições financeiras ${ }^{781}$.

Segundo CUTLER, a mercatocracia (mercatocracy) seria uma elite composta pelos mercadores (merchants) transnacionais (instituições financeiras, bancos $\mathrm{e}$ empresas transnacionais) e suas associações (CCI, por exemplo), advogados privados e suas associações (International Law Association, por exemplo), contadores e auditores, oficiais da esfera governamental e representante das organizações internacionais e intergovernamentais $^{782}$.

Já FRIGNANI rejeita a objeção de que não é possível individualizar os membros da societas mercatorum e afirma, ao contrário, que seus membros são todos pessoas físicas e jurídicas, privadas ou públicas que dão vida (pongono in essere) aos contratos internacionais $^{783}$.

A (não-)individualização de FRIGNANI parece dar margem à confusão quanto aos papéis desses participantes. Por exemplo, como a lex mercatoria aplica-se a contratos comerciais internacionais, business-to-business, a participação das pessoas físicas deve ser na qualidade de representante das empresas, organizações internacionais, entidades profissionais ou de árbitro. Além disso, não esclarece os papéis exercidos, diferenciando o papel imediato e mediato das empresas do essencialmente mediato e institucional das associações e organizações internacionais, por exemplo.

Em síntese, a societas mercatorum é formada por Estados, organizações internacionais e intergovernamentais, ONGs e empresas transnacionais, entidades profissionais de caráter coletivo e os prestadores de serviços jurídicos e contábeis ${ }^{784}$, cujos laços expressam interesses comuns relacionados às necessidades do comércio

\footnotetext{
${ }^{779}$ B. GOLDMAN, La lex mercatoria dans les contrats..., p. 478.

${ }^{780}$ P. KAHN, La vente commercial internationale, Paris, Sirey, 1961, pp. 35 e ss.

${ }^{781}$ P. KAHN, Droit international économique..., p. 100.

782 A. C. Cutler, Private Power..., pp. 21-2, 185, 192-3. Segundo CuTLER (pp. 180-1) "global mercatocracy" é "an elite association of public and private organizations engaged in the unification and globalization of transnational merchant law. This elite exercises near hegemonial influence as the 'organic intellectuals' of the international capitalist class, materially, ideologically, and institutionally".

783 A. FRIGNANI, L'arbitrato commerciale internazionale..., p. 138.

${ }^{784}$ Vide item 3.3.
} 
internacional, geridos por organizações internacionais, organizações intergovernamentais e entidades privadas de caráter coletivo, sejam entidades profissionais ou outras organizações não governamentais.

\subsubsection{A nova lex mercatoria como ordenamento jurídico}

De qualquer modo, independentemente de quem são os membros da societas mercatorum, é evidente que a nova lex mercatoria não deve ser analisada sob a perspectiva monista, a partir do Estado, e que as objeções a ela formuladas com base em ou em comparação com tal paradigma tendem a não ser sustentáveis. O Estado é apenas uma forma de organização da sociedade e o direito comercial não nasceu ou mesmo, de certa forma, nunca coincidiu integralmente com o Estado. A definição do direito pela sanção não é a única forma ou necessariamente a mais adequada para se definir ou moldar fenômenos transnacionais cuja juridicidade se pretenda ${ }^{785}$.

TEUBNER, por exemplo, adverte que o direito transnacional - a que o jurista alemão denomina de global law ${ }^{786}$ - é uma ordem jurídica que não deve ser caracterizada como um conjunto subdesenvolvido de regras com certas deficiências estruturais em relação à ordem estatal ${ }^{787}$.

Se os padrões estatais fossem os únicos meios de medir os fenômenos jurídicos, o ordenamento da Igreja Católica e o ordenamento jurídico esportivo, por exemplo, não existiriam, assim como o ordenamento interestatal ou internacional ${ }^{788}$.

PELLET afirma que ao menos quatro características aproximam a lex mercatoria do direito internacional público. Assim como este, aquela é “"non territorialisée'; elle s'applique à des activités, des 'espaces juridiques' et non des espaces geógrapiques determinés;”. Além disso, à semelhança do direito das gentes, a nova lex mercatoria "est marquée par une forte décentralisation normative; elle émane des sujets mêmes auxquels elle s'applique et le droit 'spontané', qui n'est pas formellement 'posé' par

\footnotetext{
${ }^{785}$ Vide M. VIRALly, Un tiers droit?..., pp. 374-5 e H. J. MERTENS, Lex Mercatoria - A Self-applying System Beyond National law?, in G. TEUBNER (org.), Global Law Without a State, Burlington, Ashgate, 2006, pp. 32-5. Este autor (p. 32) aponta que "if lex mercatoria is defined as a body of international legal practice, if a legal system is further defined as a system of norms which renders judicial decisions possible and if the term 'independent' is defined as 'relatively independent from national laws', international legal and economic practice reveals that lex mercatoria does exit as an independent legal system".

${ }^{786}$ Vide item 4.2.

${ }^{787}$ G. TEUBnER, 'Global Burkowina'..., p. 4.

788 F. MARrella, La nuova lex mercatoria..., p. 650. Também, nesse sentido, N. BobBio, Teoria dell'ordinamento giuridico..., p. 164 e M. V. D. KERCHOVE, F. OST, Legal system between..., 134.
} 
leur volonté y joue un grand rôle". Uma terceira característica é que esse direito transnacional também "repose sur des mécanismes de sanction imparfaits...". Por fim, assim como o direito internacional público, a nova lex mercatoria tem como fonte normativa os princípios gerais de direito ${ }^{789}$.

Segundo Teubner, trata-se de um direito 'proximamente acoplado' com processos sócio-econômicos, sem apoio político ou institucional ${ }^{790}$.

Embora algumas reservas devam ser feitas à afirmação de Teubner $^{791}$, ela demonstra que a investigação a respeito da nova lex mercatoria deve ao menos iniciar por uma abordagem pluralista e sociológica ${ }^{792}$. De acordo com KONRADI e FIX-FIERRO, "legal sociology should primarily focus on the processes of norm creation, the mechanism for the stabilization of expectations within particular social systems, as well as on the structural consequences of this type of self-regulation for both global law and national law,"793.

CUTLER alerta que, atualmente, há uma crescente e mais aguda assimetria ou disjunção entre o status jurídico formal das empresas transnacionais e demais participantes privados na societas mercatorum e seus respectivos significados políticos efetivos, o que leva a uma crise de identidade. Há uma expansão de fato da autoridade desses atores na criação da lei que, embora mais consistente com a cultural mercantil, não é refletida pelas ordens jurídicas estatais ou pela ordem internacional ${ }^{794}$.

É assim necessário compreender o caráter institucional de alguns dos atores privados da nova lex mercatoria. Segundo KonRADI e FIX-FIERRO, "institutionalization implies the existence of a more or less dense network of organizations and associations which accomplish several functions. First, they promote the building of connection and links between merchants within the industry. Second, they represent the collective

\footnotetext{
${ }^{789}$ A. PELLET, La lex mercatoria “tiers ordre juridique”?..., p. 59.

${ }^{790}$ G. TEUBNER, 'Global Burkowina'..., p. 4.

${ }^{791}$ Vide capítulo 2.

${ }^{792}$ V. OlgIATI, Lex mercatoria e communitas..., p. 357, salienta que "nell'ordiena realtà sociale... si vanno estendendo rapporti sia di co-esistenza che di co-varianza tra vecchi e nuovi fenomeni di corporatismo sociale e vecchi e nuovi fenomeni di pluralismo giuridico", relações estas que "alimentano una crescente cortocircuitazione, spaziale e temporale, tra le più diverse variabili sociali: tra produzione $\mathrm{e}$ consumo, tra potere economico e controllo politico, tra bisogni esistenziali primari e rappresentazione sociale degli stessi, e così via".

${ }^{793}$ W. KONRADI; H. FIX-FIERRO, Lex mercatoria in the mirror ..., p. 222.

794 A. C. Cutler, Private Power..., p. 113, pp. 194-6. Segundo a autora (p. 21), "today transnational corporations are significant de facto subjects of law, notwithstanding their analytical status as 'objects' and not 'subjects' of law and their theoretical insignificance or 'invisibility' under international law". Segundo M. R. FERRARESE, Le istituzioni della globalizzazione..., p. 95, o direito é influenciado por sujeitos (como as grandes empresas transnacionais) que não são jurídicos (seriam objeto, na linguagem de Cutler), o que torna os meios de legitimação e legalização mais privados e secretos, fazendo do direito um jogo de claro-escuro.
} 
interests and autonomy of the merchant community. Third, they elaborate specific policies and standards to which members of the trade must conform. And finally, they provide formal or informal mechanisms for inducing compliance with such internal policies and standards, as well as for the settlement of disputes" ${ }^{\text {"795. }}$.

GOLDMAN anota que os "organismos profissionais com certeza não são autoridades públicas...; mas os operadores do comércio internacional não os consideram menos qualificados para definir as normas"796. Em mais de uma ocasião, já foi recordado, por exemplo, o papel das entidades profissionais e das outras organizações não governamentais, especialmente da CCI. Essas associações, privadas mas de relevância pública ou interesse coletivo, têm caráter institucional, exercem uma certa medida de autoridade e têm atividade normativa.

Essa atividade não repousa no comportamento individual ou em um fato isolado, mas sim - e aqui valem os comentários já tecidos ao caráter normativo dos usos e dos princípios gerais - na repetição e difusão dos comportamentos e na sua aceitação e vinculação como jurídicos ${ }^{797}$. MARRELLA conclui, assim, que a lex mercatoria não consiste em mera manifestação de autonomia privada, como sugerem análises do ponto de vista estatal, mas sim em um ordenamento jurídico toda vez que aquela manifestação for assimilada pela business community ${ }^{798}$.

FRIGNANI, que também afirma a juridicidade da nova lex mercatoria com base no fato de ser "percepita ed applicata come un corpo di norme giuridiche dalla comunità internazionale dei 'mercanti' (nel senso che si applica anche in assenza di un esplicito o implicito richiamo ad opera delle parti)", acrescenta que ela é jurídica também por ser "riconosciuta dagli organi legislativi e/o giurisdizionali degli Stati come fonte di un ordinamento autonomo" 799 .

\footnotetext{
${ }^{795}$ W. KONRADI; H. FIX-FIERRO, Lex mercatoria in the mirror ..., pp. 222-3.

${ }^{796}$ B. GOLDMAN, Frontières..., p. 184.

797 Segundo F. MARRELLA, La nuova lex mercatoria tra controversie..., p. 255, "non sono i comportamenti individuali degli operatori o il singolo fatto posto in essere che hanno di per sé un carattere normativo. La loro rilevanza sul piano del diritto, cioè la loro idoneità a produrre effetti giuridici, non dipende tanto dalla forza che quei comportamenti avvrebero in sé, ma dal loro realizzarsi in modo ripetitivo e diffuso nella business community. Cioè il fulcro della lex mercatoria non è nei comportamenti isolatamente considerati, ma nel loro essere acompagnati dall'atteggiamento di approvazione o disapprovazione che assume la business community rispetto ai comportamenti stessi. Pertanto, la normatività della lex mercatoria e dei suoi singoli elementi costitutivi ... non è tanto una qualità intrinseca ai singoli elementi quanto un carattere che va rapportato al contesto in cui realizzano e cui sono connessi".

${ }^{798}$ F. MARRELLA, La nuova lex mercatoria tra controversie..., p. 259.

799 A. FRIGNANI, L'arbitrato commerciale internazionale..., pp. 138-9. De acordo com a classificação de J. VANDERLINDEN, Le pluralisme juridique..., p. 27, a nova lex mercatoria constituiria uma ordem jurídica para realizar a especificidade de uma instituição. Vide item 2.5.
} 
Por fim, Pellet observa, em síntese, que a nova lex mercatoria comporta, sem dúvida, regras de conduta que seus destinatários observam, de forma ao menos tão satisfatória quanto os Estados na ordem jurídica internacional. Além disso, conta com juízes (essencialmente os árbitros) que aplicam suas regras, cuja intervenção, embora menos sistemática que aquela dos juízes estatais, está à frente em relação à intervenção dos juízes internacionais para aplicação do direito internacional público. Da mesma forma, as sanções da nova lex mercatoria são menos aleatórias do que aquelas do direito internacional público ${ }^{800}$. Dessa forma, conclui o internacionalista francês, "si l'observation de la réalité (juridique) conduit à constater qu'il existe bien un corps de règles, fonctionnant selon une logique (juridique) qui lui est propre, on ne voit pas pourquoi cette qualification lui serait refusée, ni pourquoi l'on n'y verrait pas le signe qu'il existe une societas mercatorum, moins éclatée et inexistant qu'on ne le dit, tant il est vrai que le droit est un révélateur, raisonnablement fiable, de la réalité des rapports sociaux. Ubi jus, ibi societas"

De qualquer modo, a caracterização da nova lex mercatoria como ordenamento jurídico, e a controvérsia a seu redor, parece ser questão mais secundária do ponto de vista prático. Os Estados, seja em sua legislação - por meio da autonomia da vontade para celebração de contratos atípicos (do ponto de vista do direito interno) e da abertura à escolha e aplicação de regras de direito na arbitragem somada à adoção em larga escala da Convenção de Nova Iorque sobre o Reconhecimento e a Execução de Laudos Arbitrais Estrangeiros - seja por meio de seus tribunais, tem dado suporte à existência da nova lex mercatoria.

Desse modo, a reflexão crítica a seu respeito deve se concentrar não tanto sobre sua existência, mas nos efeitos a que dá causa.

\subsubsection{A nova lex mercatoria como fator de desequilíbrio e a questão da legitimidade}

É recorrente a afirmação de que a nova lex mercatoria pode ser fator de desequilíbrio em níveis distintos. Entre as partes durante as negociações, celebração e execução dos contratos. Em uma disputa, seja entre as partes, seja entre o tribunal

\footnotetext{
${ }^{800}$ A. PELLET, La lex mercatoria "tiers ordre juridique”?..., p. 73. Vide também M. VIRALLY, Un tiers droit?..., pp. 384-5.

${ }^{801}$ A. PELLET, La lex mercatoria “tiers ordre juridique”?..., pp. 69-70.
} 
arbitral e uma ou mais partes. E, por fim, em relação a terceiros, estranhos à societas mercatorum. Isto é, os efeitos do desenvolvimento e aplicação da nova lex mercatoria podem ser nocivos à sociedade como um todo ${ }^{802}$.

A premissa das objeções dessa natureza pode ser refletida na afirmação de CUTLER de que a mercatocracia (ou business community ou societas mercatorum) constitui uma força social transnacional, baseada na consciência de uma preocupação comum de manter um sistema que possibilite àquela classe a manutenção de uma posição dominante, buscando o estabelecimento de uma economia global sem fronteiras, com erradicação do nacionalismo econômico, de forma a harmonizar, unificar e globalizar a merchant law ${ }^{803}$.

Ou seja, essas objeções podem ser traduzidas, resumidamente, na afirmação de KAHN de que a finalidade da nova lex mercatoria, como expressão da juridicidade da societas mercatorum, é servir interesses econômicos, o que constitui, a um só tempo, seu limite e fraqueza ${ }^{804}$. Teme-se um surto de liberalização selvagem das contratações, salienta MARRELLA ${ }^{805}$. GALGANO observa que "il particolarismo del diritto commerciale è, in termini gramsciani, economismo $;. .$. L'economismo nel diritto del nostro tempo è la pretesa di separare il diritto dalla politica, di astrarlo dalla società, quale mero acessorio dell'economia, pura tecnica di regolazione dei rapporti di produzione" ${ }^{\circledR 06}$.

Esse economismo, segundo OlgIATI, reflete uma nova forma de fundamentalismo jurídico, o das grandes corporações econômico-financeiras orientadas ao mercado para afirmar sua própria dominação organizacional sobre a dinâmica de todo o sistema social. Esse fundamentalismo cresceu não somente dentro dos confins simbólicos e materiais do Estado, mas também além dele e, paradoxalmente, com base em garantias do próprio Estado. E por não estar necessariamente radicado em um Estado, pode se relacionar de forma elástica e conjuntural com o ambiente, o que levaria, segundo OLGIATI, a uma total autonomia e irresponsabilidade política ${ }^{807}$. Nesse

\footnotetext{
${ }^{802}$ N. BOSCHIERO, La lex mercatoria nell'era della globalizzazione ..., p. 129, rotula essas considerações de natureza política de "l'horror legis mercatoriae".

${ }^{803}$ A. C. Cutler, Private Power..., pp. 181-6, também com base em L. Sklair (The Transnational Capitalist Class, 2001) e em R. Cox (Critical Political Economy, 1995). Segundo a autora (p. 181) "global mercatocracy" é "an elite association of public and private organizations engaged in the unification and globalisation of transnational merchant law. This elite exercises near hegemonial influence as the "organic intellectuals' of the international capitalist class, materially, ideologically, and institutionally".

${ }^{804}$ P. KAHN, Droit international économique..., p. 100.

${ }^{805}$ F. MARRELla, La nuova lex mercatoria..., p. 638.

${ }^{806}$ F. GALGANO, Lex mercatoria, pp. 12-3.

${ }^{807}$ V. OlgIATI, Lex mercatoria e communitas..., p. 362-3. Segundo OlgiATI (p. 361), a forma clássica do fundamentalismo jurídico seria direito positivo da 'forma-Estado', assim como proclamada pelo projeto
} 
contexto, ressalta o autor italiano, "non sorprende, quindi, che la Lex Mercatoria sia stata via via strumentalizzata allo scopo, in virtù dei 'vantaggi competitivi' offerti dalla sua specifica configurazioni funzional-strutturale"... quanto più essa (lex mercatoria) ha ... via via perso la sua originale e primaria ratio juris quale estremo e residuale rimedio tecnico giuridico rispetto al diritto ufficiale (assumendo, per contro, una diffusa e pervasiva valenza ideologico-politico antagonistica), tanto più gli interessi e la lealtà politica della intera Communitas Mercatorum si sono identificati bensì con la logica generale del mercato, ma piegandosi alla logica organizzativa particolare delle corporazioni di appartenenza o riferimento".

A objeção do economismo pode ser expressa também na pretensão de universalismo da nova lex mercatoria. Mas universalismo não sentido, histórico, de que o direito comercial sempre se aspirou cosmopolita, para além das fragmentações territoriais (políticas), mas sim no sentido dado por WALLERSTEIN ${ }^{808}$. Isto é, um modo a que ele denomina particularmente europeu - de tentativa de dominação pela imposição de valores propriamente europeus como valores globais, universais.

SANTOS e RoDRíGUEZ-GRAVITO, por sua vez, ressaltam que "more often than not... cosmopolitan and legal projects have been as Western ${ }^{809}$ - or North-centric and exclusionary as the global designs they oppose" ${ }^{\wedge 10}$. CUTLER, por exemplo, faz menção a um imperialismo jurídico do ocidente, a partir da evocação de costumes próprios e influência na criação das instituições, leis e padrões de arbitragem ${ }^{811}$, principalmente quando a arbitragem é concebida como um clube fechado ${ }^{812}$.

político liberal burguês. Para ele (p. 362), esse novo fundamentalismo, pela "potenza di mezzi, capacita di radicamento, vocazione universalistica, ecc., non ha certo nulla da invidiare rispetto a quello tuttora (ma a stento) connesso alla forma Stato".

${ }^{808}$ I. WALLERSTEIN, European Universalism..., p. 60. O autor (p. 73) comenta que "não há nada tão etnocêntrico, tão particularista quanto a pretensão ao universalismo". P. S. BERMAN, From international law..., pp. 541-2, por outro lado, adverte que "cosmopolitismo não pode ser confundido com universalismo. Para ele, "a cosmopolitan conception of law... aims to capture a middle ground between strict territorialism on the one hand and expansive universalism on the other. ... cosmopolitan conception does not require a universalist belief in a single world community"

${ }^{809}$ N. BoschIERo, La lex mercatoria nell'era della globalizzazione ..., p. 130 relata, por exemplo, que para M. Sornarajah (The Uncitral Model law - A Third World Point of View, 1989) que nova lex mercatoria seria "a creation of Western scholars and arbitrators who have loaded it with norms entirely favourable to international business".

${ }^{810}$ B. DE S. SANTOS; C. A. RoDRIGUEZ-GRAVITO, Law, politics, and the subaltern in counter-hegemonic globalization, in B. DE S. SANTOS; C. A. RodRIGUEZ-GRAVITO (ed.), Law and Globalization from Below Towards a Cosmopolitan Legality, Cambridge, 2005, p. 13.

${ }^{811}$ A. C. CUTLER, Private Power..., p. 234.

${ }^{812}$ Y. DeZAlAY; B. GARTH, Merchants of law..., pp. 27 e ss. Os autores (pp. 39 e ss.) apontam para a existência de uma nova geração de árbitros, técnicos, empreendedores, profissionais da arbitragem, que vêem a necessidade de racionalizar e institucionalizar a arbitragem, de forma acompanhar seu boom, em contraposição aos great old men, eminentemente professores. A nova geração conta com o apoio também 
Esse universalismo é, assim, não só europeu, mas também ocidental. O debate pode ser analisado, assim, sob perspectiva da relação norte-sul/ocidente-oriente, dominada pelo norte e pelo ocidente ${ }^{813}$. KONRADI e FIX-FIERRO argumentam que, embora a lex mercatoria tenha sido único meio para buscar um meio termo nas disputas entre as empresas transnacionais e os países em desenvolvimento (disputas norte-sul), o que lhe garantiu sucesso prático, sua utilização acabou por proteger o poder econômico e interesses do Ocidente ${ }^{814}$.

De qualquer forma, para alguns autores, como CUTLER a nova lex mercatoria não representaria globalização da cultura jurídica, mas globalismo localizado da cultura e práticas dos EUA pelo domínio de práticas e leis de empresas estabelecidas nos EUA - um exemplo poderia ser a própria americanização da $\operatorname{arbitragem~}^{815}$. Aos países periféricos não restaria senão a escolha desse globalismo localizado, ao passo que os países centrais se especializam em localismos globalizados ${ }^{816}$.

Analisando primeiramente os efeitos "internos" da nova lex mercatoria, é comum afirmações como a de GIARDINA, segundo quem "i mecanismi spontanei di formazione dei principi e delle regole della lex mercatoria favoriscono indubbiamente l'affermarsi ed il consolidarsi di soluzioni che tutelano maggiormente i membri più forti e attivi dela c.d. societas mercatorum".

Salienta PANNARAle que a autonomia pode também ser autoritária e de forma muito mais opressora sempre que o poder tecnológico de um número pequeno de empresas está em condições de influenciar todo o planeta ${ }^{817}$. O fenômeno se agrava

das law firms. A respeito de um jovem árbitro suíço, um advogado americano afirmou que "it's the younger generation I like, because all of them have gone to school in the United States. They all speak fluent English. They know how to deal with Americans and English, and they move cases along". Mas mesmo, assim, muitos árbitros da nova geração são discípulos dos great old men e, além disso, os mais velhos continuam a ser chamados nos casos mais sensíveis.

${ }^{813}$ Essa é uma das críticas que HERMES MARCELO HUCK desenvolve em Sentença Estrangeira ... Em um primeiro momento da nova lex mercatoria, o antagonismo era entre o capitalismo e o socialismo, principalmente no que dizia respeito aos State contracts. Um dos maiores expoentes dos países socialistas em matéria de lex mercatoria foi A. Goldstajn.

${ }^{814}$ W. KONRADI; H. FIX-FIERRO, Lex mercatoria in the mirror..., p. 216, com base em Y. Dezalay e B. Garth (Dealing in virtue - International Commercial Arbitration and the Construction of a Transnational Legal Order 1996).

${ }^{815}$ Vide n.r. 753 acima.

${ }^{816}$ A. C. CuTler, Private Power..., p. 235, com base em B. de. S. Santos (Toward a New Common Sense - Law, Science, and Politics in the Paradigmatic Transition, 1995). CuTLER relata (p. 235) também, sempre com base em B. de. S. Santos, que na China, a lex mercatoria convive com influências do capitalismo e modernização chineses, com prioridade à state policy, tradição, cultura e quanxi ("a highly personalized system of familial, clan, and friendship networks regulating social and economic relations and mediates the interface of foreign and domestic practices"), razão pela qual a lex mercatoria estaria sendo 'quanxified'.

${ }^{817}$ L. PANNARALE, Delocalizzazione del diritto..., p. 318. 
quando considerado que, na sociedade pós-industrial, o contrato é entendido mais como fonte normativa, sendo um dos importantes instrumentos pelos quais o direito muda ${ }^{818}$. O autor italiano observa, porém, que o caráter impositivo das condições gerais das grandes empresas transnacionais é fonte de relevante assimetria entre as partes ${ }^{819}$.

Embora tal colocação e afirmação sejam corretas e devam levar à reflexão e reconsideração de algumas questões, sua relação com a nova lex mercatoria deve ser relativizada.

Por um lado, não é exatamente claro como tal fenômeno é diferente quando as condições gerais estão submetidas a um direito nacional. Como já observado, tanto a nova lex mercatoria como os direitos de origem estatal são formados por um conjunto de princípios voltados ao estabelecimento, tanto quanto possível, de equilíbrio entre as partes durante a negociação e execução do contrato, como por exemplo o princípio da boa-fé objetiva (e os conseqüentes deveres de informação, cooperação, entre outros) ou a regra contra proferentem, para interpretação dos contratos (art. 4.6 dos Princípios UNIDROIT).

Por outro lado, mesmo que as práticas contratuais - sejam os contratos-tipo, as cláusulas padrão ou as condições gerais - possam de fato, levar à formação de usos que são por sua vez fonte da nova lex mercatoria - a simples repetição de sua utilização é insuficiente para tanto. Sempre que não haverá a formação de uso normativo sempre que faltar a opinio iuris - convicção de que tais práticas são ou devem ser jurídicas - às condições gerais ${ }^{820}$.

Ocorre que, para alguns autores, como CUTLER, a posição atribuída à soft law e ao uso na nova lex mercatoria é estratégica e reflete os interesses dos Estados ocidentais desenvolvidos e favorece as grandes empresas transnacionais. Basta, segundo a autora britânica, analisar o processo de negociação da CISG em que os Estados Unidos e a Inglaterra lutaram pelo papel dos 'regularly observed trade usages ${ }^{\text {, }}{ }^{81}$. De maneira

\footnotetext{
${ }^{818}$ Vide item 2.7.

${ }^{819}$ L. Pannarale, Delocalizzazione del diritto..., p. 319. Segundo A. C. Cutler, Private Power..., pp. 220-1, typically, asymmetrical relations are built right into such contracts (contratos-tipo, condições gerais), but this is obscured by their technical nature, their general acceptance, and the frequency of their use".

${ }^{820}$ Vide A. FRIGNANI, L'arbitrato commerciale internazionale..., p. 143, E. LOQUIN, Où en est la lex mercatoria..., p. 33 e itens 3.5.2, 3.5.3 e 4.1.2.1.

821 A. C. CUTLER, Private Power..., pp. 222 e ss. Vide também, especificamente a respeito do direito internacional, J.M. PUREZA, Defensive and oppositional counter-hegemonic uses of international law from the international criminal court to the common heritage of humankind, in B. DE S. SANTOS, C. A. RoDriguEZ-GRAVITO (ed.), Law and Globalization from Below - Towards a Cosmopolitan Legality, Cambridge, 2005, pp. 267-80, particularmente pp. 276-7. A. ROSETT, The many paths to harmony in
} 
geral, os usos e os instrumentos de soft law são mais eficientes porque mais flexíveis, adaptáveis e mais fáceis de negociar. Ocorre que a escolha estratégica da soft law, para CUTLER, pode ser fator de desequilíbrio, beneficiando "only those businesses that are large and dispersed enough to carry risks generated by uncertain standards ${ }^{\prime 822}$. Esses instrumentos criam, para a autora britânica, uma aparência de consenso, reprimindo e neutralizando o dissenso por parte dos Estados mais periféricos. Mais uma vez, o exemplo dado é o processo de negociação da CISG, em que alguns temas foram excluídos das discussões ${ }^{823}$.

Note-se, porém, que a escolha e a aplicação da nova lex mercatoria, embora de um lado possa conduzir a desequilíbrios que pendam à parte economicamente mais forte, pode, de outro lado, tornar a solução da disputa mais previsível e até mais justa ou imparcial.

LANDO ressalta que "by choosing the lex mercatoria, the parties oust the technicalities of national legal systems and they avoid rules which are unfit for international contracts. Thus, they escape peculiar formalities, brief cut-off periods, and some of the difficulties created by domestic laws which are unknown in other

international commercial law, in New Trends in International Trade Law - Contributions on the Occasion of the $10^{\text {th }}$ Anniversary of the International Trade Law Course, Torino, G. Giappicheli, 2000, p. 323 enfatiza que a "soft law, be it embodied in case law, private rules, or arbitral decisions is likely to be a private law. Its inaccessibility is increased by the need to place statements of the law in some hierarchichal setting. The same powerful economic forces and technological changes that mandate legal change in international transactions through international conventions are felt at the national level. As nations reconsider their own laws in response to those forces, they are likely to arrive parallel conclusions, thus reducing the differences among laws of these nations.... This convergence reflects the truth that, in economic terms, the lines between domestic and international transactions are being eroded within global markets. The result will be a harmonized legal approach to all similar commercial transactions.... Emphasis on private, rather than state rules, also is the core of the approach to harmonization taken in numerous industries, trade practices, uniform contract forms, and trade association rules".

${ }^{822}$ A. C. Cutler, Private Power..., pp. 220 e ss. Segundo CuTLER, os Estados em desenvolvimento, ao contrário, tendem a preferir a formação de regras pelo processo da hard law, já que ele pode garantir, ao menos, algum nível mínimo de acessibilidade - algumas regras têm funcionado como barreiras que impedem a entrada desses atores em um comércio - e transparência. Isto porque, para ela, "hard law norms, in contrast, regulate the terms of competition more closely and visibly, probably benefiting smaller businesses which face high transaction costs in collecting information about national rule differences".

${ }^{823}$ Idem. Para CUTLER, "in a similar vein, the increasing informality and personalized nature of law merchant discipline assists in locking peripheral states into neoliberal market disciplines by disarming them and neutralizing their dissent. Arguably, major conflicts of interest are much more visible in formal negotiations of hard treaty law where the scope of concessions granted by the more powerful states are obvious. In contrast, soft discipline is by definition unenforceable and, as a result, even the most generous concessions may in actuality be quite meaningless". Vide M. J. BonELL, The UNIDROIT Principles of International Commercial Contracts and CISG..., p. 28. 
countries... ${ }^{924}$. É nesse sentido, por exemplo, que GAILLARD aponta que, às vezes, a não escolha de um direito aplicável ou a referência direta ao direito transnacional reflete a intenção das partes de neutralizar ou excluir a vantagem que cada parte obteria pela aplicação do direito de seu país ${ }^{825}$.

Assim, a escolha de um direito transnacional - da nova lex mercatoria -faz com que os custos de informação sobre o direito aplicável sejam igualmente distribuídos entre as partes, com conseqüente diminuição das assimetrias de informação, permitindo um ponto de partida contratual mais equilibrado. E, além disso, com a crescente consolidação e difusão dos princípios gerais da nova lex mercatoria, dos usos e da jurisprudência arbitral, o conteúdo da nova lex mercatoria será cada vez mais acessível e conhecido pelos operadores, de modo que os custos de informação com a escolha desse direito transnacional tendem a diminuir ${ }^{826}$.

Já em caso de disputas resolvidas por arbitragem, a discussão se desdobra. Além da afirmação de que o conteúdo em si da nova lex mercatoria favoreceria uma das partes, alguns, como MAYER, sustentam que a aplicação da nova lex mercatoria, em razão da freqüente utilização de princípios gerais como o da boa-fé, poderia dar ensejo a arbitrariedade por parte dos árbitros ${ }^{827}$.

A afirmação de MAYER é rejeitada por LANDO, uma vez que, quando aplicada a nova lex mercatoria, "those involved in the proceedings - parties, counsel and arbitrators - plead and argue on an equal footing; nobody has the advantage of seeing it governed by his own law, and nobody has the handicap of seeing it governed by a foreign law" ${ }^{\prime 828}$. Especificamente em relação aos árbitros, o jurista dinamarquês observa que "those who have participated in an international arbitration governed by foreign law have experienced the frustration of being told the law by a participant who is a 'native' of that legal system. If the native is not the sole arbitrator or the president of the tribunal, but one who is or may be suspected of being interested in the outcome of the

${ }^{824}$ O. LANDO, The lex mercatoria in international commercial arbitration, in The Lex Mercatoria In International Commercial Arbitration, in International and Comparative Law Quarterly, v. 4, n. 34, 1985 , p. 748.

${ }^{825}$ E. GAILLARD, Transnational law..., p. 70.

${ }^{826}$ F. MARRELLA, La nuova lex mercatoria tra controversie..., pp. 284-5. A afirmação é verdadeira mesmo quando comparada a escolha da nova lex mercatoria com a escolha do direito de um terceiro país. O autor observa que a utilização da nova lex mercatoria, como fator de redução de custo de informação, faz ainda mais sentido do ponto de vista da holding em relação às operações entre empresas do mesmo grupo.

${ }^{827}$ P. MAYER, Le Principe de Bonne Foi..., p., 549. Embora, segundo citação de F. OsMAN, Les príncipes généraux..., p. 314, a opinião expressada por MAYER (L'autonomie de l'arbitre dans l'appréciation de as propre compétence, 1989) seria outra.

${ }^{828}$ O. LANDO, The lex mercatoria in ..., p. 748. 
dispute you may have reason to fear that you are not always told the whole truth about the law. Nevertheless, you remain the foreigner who speaks without authority, you are the dilettante where the other is the expert. If he is your co-arbitrator you have often very little to say" ${ }^{\$ 29}$. É até por isso que GAILLARD afirma que é mais equânime a utilização do direito transnacional do que deixar ao arbítrio dos árbitros a escolha da lei aplicável $^{830}$.

Com o intuito de minimizar tais problemas, mesmo em caso de aplicação de um direito nacional, os árbitros muitas vezes recorrem à nova lex mercatoria, especialmente aos Princípios UNIDROIT, a fim de garantir que a decisão proferida seja compatível com a solução que seria dada se o novo ius mercatorum fosse aplicado, a que MARRELlA denomina de "filtro cultural" ou "teste de transnacionalidade" 831 .

Mesmo assim, como salientado, o desequilíbrio pode ser cunhado no próprio contrato, até porque, como salienta BORTOLOTTI, os contratos internacionais tendem a ser mais completos, deixando menos espaço para disposições supletivas ${ }^{832}$. E, embora os árbitros tenham algum poder para corrigir eventual desequilíbrio, por meio da aplicação do princípio da boa-fé e seus desdobramentos, a questão que se coloca é: até que ponto o tribunal arbitral pode fazê-lo sem exceder o seu mandato e de forma compatível com a previsibilidade (essencial, mas não absoluta) de suas decisões?

Por outro lado, a intervenção dos árbitros em razão de ordem pública é, e deve ser, limitada, seja em relação ao número de intervenções, seja em relação ao escopo ou conteúdo da exceção fundada em ordem pública ${ }^{833}$.

${ }^{829}$ O LANDO, Assessing the Role of the UNIDROIT Principles in the Harmonization of Arbitration Law, in Tulane Journal of International and Comparative Law, 1994, pp. 140-1.

${ }^{830}$ E. GAILlARD, Transnational law..., p. 70.

831 A base de dados da Unilex dá notícia de 112 decisões, 59 das quais laudos arbitrais, que utilizar os Princípios UNIDROIT para interpretar ou suplementar o direito nacional aplicável, cf. disponível [online] in http://www.unilex.info/dynasite.cfm?dssid=2377\&dsmid=13621\&x=1 [4.1.2009]. F. MARRELLA, La nuova lex mercatoria..., p. 431, recorda que os Princípios UNIDROIT são utilizados como filtro das normas nacionais aplicáveis com base em um "test di transnazionalità (T-test o TNT-test) effettuato $a$ posteriori dagli arbitri. In base ad esso, gli arbitri, una volta determinata la legge competente, potranno verificare se le norme dell'ordinamento interno richiamato non divergano da quei principi elementari ed universali di disciplina generale del contratto espressi nei Principi Unidroit. L'arbitro in tale contesto potrebbe applicare solo le norme che si trovano in linea o in un rapporto di coerenza con i Principi disapplicando nel contempo le norme di contenuto troppo localistico".

${ }^{832}$ F. BoRTOLOTTI, The ICC Model Contracts..., p. 88.

${ }^{833}$ Isto não significa, porém, que o conteúdo atual da ordem pública é ideal ou suficiente, como se verá mais adiante. E. LoQuin, Où en est la lex mercatoria?..., pp. 50-1, "l'important ... est que la lex mercatoria fait prévaloir, au-delà des lois du marché, des intérêts supérieurs". "L'utilitarisme de la lex mercatoria s'accommode peu des préoccupations éthiques. Condamner la corruption n'est peut-être qu'une manière de préserver les intérêts du commerce international. Il n'est pas sûr que cet ordre publique protège ... 'des intérêts supérieurs à ceux de la société des marchands', mais bien plutôt 'les intérêts immédiats de la société des marchands". De acordo com A. C. CUTLER, Private Power..., p. 230, "others, 
É porque os árbitros nem sempre estão em condição de estabelecer um equilíbrio material entre as partes que PANNARALE sustenta a necessidade de uma tutela específica voltada mais à formação do contrato do que à sua execução ${ }^{834}$.

Por essas razões, PANNARALE pondera a importância de individualizar quem são os sujeitos da nova lex mercatoria: seriam só as empresas grandes ou todos que habitualmente estão envolvidos em atividades do comércio internacional, de modo que aceitar as regras da nova lex mercatoria "diventa quasi un prezzo da pagare o un rischio da correre per essere ammessi a far parte della societas mercatorum?" Mais do que isso, essa societas mercatorum, questiona, é capaz de desenvolver, em seu interno, uma dialética de tipo democrático ou não se caracteriza como fortemente oligárquica? ${ }^{835}$.

Como bem aponta MARrella, "l'esistenza e la diffusione della nuova lex mercatoria indica che la governance dei mercati mondiali è di tipo pluridimensionali e post-statale nel senso che accanto agli Stati ed alle Organizzazioni intergovernative un ruolo non secondario è svolto da enti privati di autoregulamentazioni” ${ }^{, 836}$.

Com a política neoliberalista e o advento do competing State, a mercatocracia, sustenta CUTLER, "unites private and public authorities comitted to the expansion of capitalism through further disembedding international commerce from national, social and democratic controls and reembedding it in the private sphere" ${ }^{~} 837$. Os atores privados, incluídas as empresas transnacionais, passam a ter um papel normativo. Mas, se por um lado produzem de fato regras jurídicas, os meios de legitimação e legalização se tornam mais secretos, fazendo do direito um jogo de claro-escuro ${ }^{838}$. Segundo

too, note that the public policy exception to the enforcement of awards is significant only in theory and not in practice". A autora (p. 233), aliás, afirma que o regime da Convenção de Nova Iorque sobre o Reconhecimento e Execução de Laudos Arbitrais Estrangeiros "expands the private sphere considerably, delocalizing transactions by narrowing the potential for judicial and public policy interventions". Além disso, o aumento do leque de questões arbitráveis (p. ex., questões concorrências ou de propriedade industrial - vide A. FRIGNANI, L'arbitrato commerciale internazionale..., pp. 69 e ss.) "when combined with the secretive, closed and highly discretionary and informal nature of international commercial arbitration, forms a powerful challenge to democratically accountable institutions", já que passa a assumir funções públicas em matérias cogentes.

${ }_{834}^{83}$ L. PANNARALE, Delocalizzazione del diritto..., p. 320.

${ }^{835}$ L. PANNARALE, Delocalizzazione del diritto..., p. 320.

${ }^{836}$ F. MARRELLA, La nuova lex mercatoria tra controversie..., p. 286.

${ }^{837}$ A. C. CUTLER, Private Power..., pp. 186 e ss., especialmente p. 191. Neoliberalismo, para autora britânica, deve ser entendido como meio mais apropriado para administrar a globalização, alcançar competitividade internacional e assegurar justiça nas relações comerciais internacionais. CUTLER (pp. 188-9) afirma que, embora reconhecendo interesse legítimo do Estado em regular o comércio internacional, a classe mercantil enfatiza que a regulamentação deve ser permissiva, supletiva e facultativa, assim como a ordem pública nacional, que deve ser sensível à dimensão internacional dos negócios.

${ }^{838}$ M. R. FerRARESE, Le istituzioni della globalizzazione..., p. 95. 
TEUBNER, 'global economic law is law with an underdeveloped 'centre' and a highly developed 'periphery' 839 .

Se o direito é um jogo de claro-escuro e se uma parcela sua é criada na periferia - isto é, na fronteira com os outros sistemas e mais longe dos auspícios Estatais - há então uma importante questão de legitimidade a ser analisada, principalmente quando considerado o interesse econômico que motiva essa produção de normas.

A questão da legitimidade envolve análise sob duas perspectivas, naturalmente inter-relacionadas. A primeira consiste na disjunção entre teoria e prática jurídica.

Segundo CUTLER, "westphalian-inspired notions of state-centricity, positivist international law, and 'public' definitions of authority are incapable of capturing the significance of nonstate actors, informal normative structures, and private, economic power in global political economy" ${ }^{\$ 40}$. O contexto do direito internacional, assim, para aquela autora, é de crise de legitimidade empírica, teórica e normativa. Do ponto de vista empírico, o direito sobre a personalidade jurídica não representa a natureza das empresas trasnacionais, a autoridade por elas exercida e sua relação com os Estados. Já em termos teóricos, o direito internacional não é capaz de acomodar a empresa transnacional a não ser de modo formalista e artificial. "The corporation is undertheorized, while the state is overtheorized", afirma CUTLER. E, por fim, as implicações normativas dessa autoridade das empresas transnacionais também não são consideradas da forma como deveriam ${ }^{841}$.

Já a segunda perspectiva envolve uma crise de legitimação democrática em relação à produção de regras de direito pela societas mercatorum e seus efeitos externos. "Infine occorre chiedersi", escreve PANNARALE, "l'organizzazione e le regole della comunità dei mercanti esauriscono i loro effetti all'interno di quella communità oppoure non hanno importanti ricadute anche su soggetti che le sono affato estranei: uomini comuni, piccole imprese, stati, organizzazioni internazionali, i quali si trovano a dover subire le conseguenze di un assetto di regole e di interessi, al quale sono

\footnotetext{
${ }^{839}$ G. TEUBNER, 'Global Burkowina'..., p. 12.

840 A. C. CUTLER, Private Power..., p. 242. CUTLER (pp. 239-40), após recordar que, como afirmou Giddens, a globalização tem movimentos contraditórios, observa que "more significant than incoherence, however, is the legitimacy crisis facing international law. The disjunction between theory and practice is in actuality a reflection of deeper disjunction between law and society that goes to the very heart of the constitution of the political identity, subjectivity, and legitimacy in the global political economy. International law is facing a profound legitimacy crisis, because its theory is so out of keeping with its practices...all constitutional orders require some measure of correspondence between their theory and their practices and a profound disjunction of the two portends a crisis of legitimacy".

${ }^{841}$ A. C. CUTLER, Private Power..., p. 255.
} 
formalmente estranei ed al quale non sono in grado di opporsi quanto più versino in situazioni di precarietà e debbolezza". Mas, mais do que isso, deve-se questionar também os efeitos da nova lex mercatoria em relação a outras ordens e conjunto de direitos fundamentais. Isto é, se uma lex mercatoria, cuja produção de regras de direito fundadas primordialmente no interesse econômico, refletindo uma aspiração hegemônica da societas mercatorum, sem uma legitimação democrática clara, não tem efeitos nocivos e pode conduzir à inexistência de tutela, por exemplo, do meio-ambiente ou dos direitos humanos ${ }^{842}$.

De certa forma, a objeção pode ser sintetizada na afirmação de CUTLER, para quem a classe mercantil não estaria mais liderando, mas sim dominando ${ }^{843}$.

É nesse contexto e a fazer face às críticas de natureza política à nova lex mercatoria que alguns destacam o papel da tecnocracia, que funcionaria como uma espécie de filtro cultural exercido pelos juristas.

GALGANO afirma que "in una società che tende, come l'ordiena società, a organizzarsi su basi planetarie, oltre la frammentazione dei singoli Stati nazionali, la legittimazione del potere si sposta su basi diverse da quelle tradizionali. Democrazia significa pur sempre governo basato sul consenso dei governati; tecnodemocrazia è un concetto nuovo, che però sembra fare a meno della ricerca del consenso" ${ }^{844}$.

O nascimento de uma espécie de tecnodemocracia por si também não soluciona o problema da representatividade e a legitimação democrática. GALGANO então, citando Montesquieu, afirma ser preferível a democracia ao despotismo iluminado apenas em razão de não haver garantia de que o último seja iluminado. Por isso, o importante para o jurista italiano é assegurar que o despotismo seja iluminado.

Vendo nos Princípios UNIDROIT verdadeira mediação ou filtro cultural por parte dos juristas, substituindo a mediação política intrínseca à formação do direito

\footnotetext{
${ }^{842}$ L. Pannarale, Delocalizzazione del diritto..., p. 320. PANNARAle afirma que (p. 323) "gli stessi diritti fondamentali si sono affermati, nelle società, al fine di stabilizzare in punti critici la distanza del sistema politico da quei processi sociali che rendono possibilie la differenziazione ed evitare così che essi siano integrati politicamente, equiparando un ordine politico e ordine generale. Nella fase attuale $\mathrm{i}$ pericoli di una possibile de-differenziazione non sono, tuttavia, ormai riconducibili ne al sistema religioso, nonstante l'enfasi con cui spesso si sottolineano qualli provenienti dai principi fondamentali dell'umanesimo islamico, e nenche più soltanto al sistema politico; essi appaiono, in misura crescente, connessi al sistema dell'economia: in questa fase e sopratutto l'ordine economico che tende ad autorappresentarsi come un ordine generale almeno in riferimento al fenomeno della globalizzazione".

${ }^{843}$ A. C. CUTLER, Private Power..., p. 255.

${ }^{844}$ F. Galgano, Lex mercatoria..., pp. 241 e ss. Também F. MARRELlA, La nuova lex mercatoria..., pp. 638 e ss., observou que "una possibile risposta a tale domanda (crítica política) può provenire dalla tecnocrazia: all'inesistenza di un vero potere politico legislativo mondiale in materia di contratti transnazionali può porsi rimedio ricorrendo alla naturale universialità del discorso tecnocratico".
} 
estatal, GALGano afirma que os Princípios UNIDROIT poderiam fazer frente à dominação desenfreada dos interesses econômicos na nova lex mercatoria, de forma a conferir equilíbrio às relações contratuais. GALGANO conclui, assim, que os Princípios UNIDROIT são fruto de uma tecnodemocrazia iluminada.

Embora de fato represente um avanço em relação ao economismo da nova lex mercatoria e possa constituir uma importante defesa contra interesses hegemônicos, a tecnocracia - especialmente Princípios UNIDROIT - apenas não é suficiente para corrigir o curso da nova lex mercatoria e também não resolvem a questão da legitimidade, na medida em que os tecnocratas têm uma grande responsabilidade política, sem ter a necessária representatividade ou legitimação democrática ${ }^{845}$.

As crises econômicas cíclicas, como a vivenciada a partir do segundo semestre de $2008^{846}$, cujos efeitos ainda se sentem, parecem de certa forma confirmar esses questionamentos. Isto é, a crise dos créditos sub-prime, que teve origem nos Estados Unidos, se alastrou por outros países, regiões e continentes, afetando crédito, consumo, produção e emprego. Além disso, não só diversas empresas severamente afetadas ou que foram à falência, como algumas tradicionais instituições financeiras (p.ex. Lehman Brothers) faliram. Outras tantas tiveram sérios problemas e foram socorridas pelos respectivos governos ou foram vendidas. Outras instituições, como a AIG, maior seguradora do mundo, foram nacionalizadas. No Brasil, outras empresas foram duramente afetadas pela variação cambial e por derivativos, como é o caso da Sadia e da Aracruz, cujas perdas estimadas somam, em conjunto, $\mathrm{R} \$ 2,7$ bilhões. Em razão deste emaranhado de causas e conseqüências, o desemprego aumentou, as economias retraíram ou estagnaram, a arrecadação de tributos caiu, os investimentos diminuíram e uma série de outros efeitos nocivos foram percebidos.

\footnotetext{
${ }^{845}$ N. BOSCHIERO, La lex mercatoria nell'era della globalizzazione ..., pp. 140-1. BosCHIERO aponta que “se non si può escludere a priori che la cd. razionalità 'tecnica' possa certamente costituire in alcuni casi una importante difesa contro l'influenza esercitata da interessi privati, non è affatto detto che questa forma di regulatory decision-making sia sempre dato di tenere adeguatamente in conto di interessi di tipo pubblicistico; ne che proceda attraverso una deliberative democracy. Il difeto di adeguate forme di governance e di legittimazione democratica di molte norme prodotte da queste epistemic communities è del resto il principale e più fondato argomento 'politico' contro la lex mercatoria, al pari dell'accentuata tendenza ad accantonare a livello di regulamentazione globale la democrazia a favore della "tecnocrazia". Já L. PANNARALE, Delocalizzazione del diritto..., p. 322, afirma "che... l'esito tecnocratico, per ora prevalente, sia l'unico esito possibile appare, nonostante tutto, assai più problematico".

${ }^{846}$ Vide a respeito, por exemplo, relatório da UNCTAD “"The Global Economic Crisis: Systemic Failures and Multilateral Remedies (2009) cf. disponível [on-line] in http://www.unctad.org/en/docs/gds20091_en.pdf [15.12.2009]
} 
Neste cenário negativo que, mesmo em vias de ser superado, deixa marcas, as atenções e críticas ficaram concentradas sobre o mercado financeiro, seja na falta de regulação ou supervisão dos governos sobre as instituições financeiras, nos bônus milionários aos executivos ou, em última instância, a mão livre do mercado.

As críticas de cunho político, fundadas no déficit democrático da nova lex mercatoria, se intensificam e se tornam mais aguda nesses momentos de crise. Ao menos duas reações foram naturais. A primeira delas, os Estados voltarão a intervir de forma mais intensa. A segunda, a nova lex mercatoria falhou, não deu certo ${ }^{847}$.

É por isso que a questão mais relevante à nova lex mercatoria, em que os debates e reflexão deveriam se concentrar, diz respeito não tanto em relação a sua existência ou inexistência, juridicidade ou ajuridicidade - questão sobre a qual os Estados não parecem divergir ${ }^{848}$, mas sim em sua viabilidade ${ }^{849}$. A crítica política à nova lex mercatoria é, assim, a que apresenta maiores desafios e proporciona os parâmetros para uma reflexão crítica da nova lex mercatoria. Assim, cabe ao jurista procurar meios para compatibilizar a existência e desenvolvimento da nova lex mercatoria com outros interesses e valores. "Infine (e sopratutto)", como afirma PANNARALE, "il sistema dei diritti della globalizzazione non può limitarsi alle merci, ignorando altri aspetti essenziali della convivenza tra gli uomini e tra i popoli ${ }^{, 850}$.

Assim, em consequiências dessas ponderações, alguns vêem como inevitável a repolitização da nova lex mercatoria ${ }^{851}$. De fato, a nova lex mercatoria deve corrigir seu curso para apreender e salvaguardar interesses que vão além da esfera econômica. Mas é pouco provável e mesmo viável que sejam repetidos os processos políticos experimentados até o momento.

\footnotetext{
${ }^{847}$ Como por exemplo afirmou António Manuel Hespanha, em resposta a uma pergunta do autor deste trabalho, durante a conferência "O iudicium no ius commune e a ideia contemporânea de ponderação" proferida pelo jurista português na Faculdade de Direito da Universidade de São Paulo em 17.4.2009.

${ }^{848}$ Como mostram julgados das cortes austríacas, belgas, italians, francesas, por exemplo. Vide F. MarRella, La nuova lex mercatoria tra controversie..., 249-85; L. PANNARALE, Delocalizzazione del diritto..., pp. 315-6 e T. RENSMANn, Anational arbitral awards..., p. 38, n. 23.

${ }^{849}$ F. OSMAN, Les principes généraux..., p. 459.

${ }^{850}$ L. PANnARALE, Delocalizzazione del diritto..., p. 322.

${ }^{851}$ G. Teubner, 'Global Burkowina'..., p. 4, por exemplo, afirma que "its relative distance from international politics will not protect global law from its re-politicization. ... We can expect global law to become politicized not via traditional political institutions but within the various processes under which law engages in 'structural coupling' with highly specialized discourses". Também A. C. CUTLER, Private Power..., pp. 255, afirma que "in a word, what is required is the reengagement of law and politics". A autora (p. 243) sugere uma crise de autoridade da mercatocracia, na medida em que forças sociais, tais como as organizações internacionais, intergovernamentais e não-governamentais (pp. 245-6), contestam os resultados por ela atingidos.
} 


\subsection{A nova lex mercatoria na sociedade pós-industrial: noção, limites e desafios}

Anotou-se como noção mínima e preliminar da nova lex mercatoria um (i) direito material; (ii) de origem transnacional, isto é, não produzido em nível nacional ou internacional por nenhum Estado específico; (iii) comportando, de outro lado, uma dimensão local transnacionalizada; cujas regras são (iv) criadas de forma espontânea, em maior ou menor escala, pela própria classe mercantil; (v) aplicáveis aos contratos comerciais internacionais; e que (vii) tem um aspecto comunicativo importante.

As fontes desse direito transnacional são (i) os usos, formulados ou não ${ }^{852}$, compreendidos pelas práticas adotadas pelos operadores, inclusive as contratuais (contratos-tipo, cláusulas-padrão, entre outros), dotadas de opinio iuris, isto é, consciência da juridicidade pelos membros da societas mercatorum conformidade de determinada prática com as necessidades do comércio internacional; (ii) os princípios gerais de direito, tal como identificados no artigo 38 do estatuto da Corte Internacional de Justiça, e os princípios específicos da nova lex mercatoria, sendo a boa-fé objetiva o princípio fundamental e os Princípios UNIDROIT sua mais importante fonte de cognição; e (iii) jurisprudência arbitral, que extrai, evidencia e enuncia os princípios gerais e os usos.

O conteúdo da nova lex mercatoria é especificamente limitado aos contratos comerciais internacionais. Embora a eles voltado, não abrange - ao menos ainda determinadas matérias, como capacidade das partes, vícios de consentimento, transferência de propriedade, entre outros ${ }^{853}$. Além disso, a nova lex mercatoria está sujeita à ordem pública internacional e à ordem pública transnacional.

Como salienta OSMAN, "la lex mercatoria constitue un ordre juridique soumis au principe de spécialité, qui cantonne son champ d'intervention dans des domaines précisément délimités ${ }^{\prime 854}$.

\footnotetext{
${ }^{852}$ Vide item 3.5.2.

${ }^{853}$ A nova lex mercatoria não se reduz à sua aplicação em arbitragens, mas consiste também na criação e circulação de instrumentos voltados ao comércio internacional, tais como os INCOTERMs, as regras sobre garantias bancárias, crédito documentário, entre outros.

854 F. OSMAN, Les principes généraux..., p. 454. De acordo com V. OlgIATI, Lex mercatoria e communitas..., p. 368, "la Lex Mercatoria ... non solo transcende qualunque ordinamento corporativo, ma è sempre stata ed è un tipico caso di particolarismo giuridico ... riprodotto a diversi livelli: basti osservare la specialità tecnica dei suoi standard;... la diversificazione deu suoi campi d'azione;... la assensa di organicità sistematica teorico-pratica; l'occasionalità contestuale del suo impiego; la limitata qualità e quantità dei casi trattati; la tipologia selettiva dei giuristi e delle parti coinvolte, la frammentaria validità ed efficacia delle procedure decisionali, ecc. ... l'odierna Lex Mercatoria altro non è se non un local legal
} 
Por isso, uma parte das críticas à nova lex mercatoria de que ela se aspira supranacional e exclusiva, a fim de substituir o Estado (e por isso a caracterizando como supranacional), é equivocada. Seu escopo não compreende a criação de regras jurídicas não relacionadas ao comércio internacional ${ }^{855}$.

Ademais, em que pese a relativização da soberania dos Estados na sociedade pós-industrial, não parece correto afirmar que todas as questões serão decididas a nível global, que o Estado, por um lado, não detém mais qualquer parcela de soberania e, por outro, deixa de ter capacidade de influenciar, em maior ou menor intensidade, os processos de formação do direito ${ }^{856}$. Basta recordar, como nível mínimo de influência, a ordem pública nacional, que pode ser suficiente para afastar a execução de um laudo, as leis de aplicação necessária e demais regras que condicionam a execução dos contratos em seu território.

Tal qual o direito internacional, a nova lex mercatoria pode ser entendida como ordenamento jurídico autônomo, fundada não em um espaço geográfico, mas em um espaço jurídico, imaterial, transnacional. Isso não implica, porém, que se prescinda do Estado. "Les relations économiques internationales sont, de facto", destaca VIRALLY, "soumises sous de nombreux aspects aux droits internes parce qu'elles ne s'établisse pas 'en l'air' et que toutes les surfaces habitables de notre planète sont aujourd'hui soumise à une souveraineté étatique ou à un autre". De certa forma, há uma dinâmica de desnacionalização/desterritorialização, para referir-se à nova lex mercatoria, e (re-) nacionalização/(re-)territorialização, quando executados em um determinado Estado ${ }^{857}$.

A autonomia significa apenas que é direito originário, próprio, mas não significa absoluta independência em relação às demais ordens e nem que estas não possam (e de certa forma devam) influir na formação de conteúdo ${ }^{858}$. A caracterização como ordenamento jurídico é apoiada em uma abordagem sociológica e pluralista do

system, e dunque, perciò stesso, un caso esemplare della pluralità delle forme contemporanee di pluralismo giuridico".

${ }^{855}$ É direito comercial e não do comércio, no sentido indicado por F. GALGANO, Lex Mercatoria..., p. 10: "il diritto commerciale non é il diritto del commercio: non regola ne mai ha regolato, tutto il commercio; non é mai stato un sistema normativo auto-sufficiente, ordinante un intero settore della vita economica". ${ }^{856}$ L. Pannarale, Delocalizzazione del diritto..., p. 322.

857 Assim, A. C. CutLer, Private Power..., p. 20, que aponta que "in some cases, merchant laws operate dialectically creating deterritorialized transactions and agreements, but then reterritorializing them to facilitate enforcement". O mesmo é aplicável mesmo para os contratos relacionados à internet, que, mesmo se mais difícil de "localizá-los", têm aspectos (inclusive prévios) sujeitos a um ordem jurídica estatal.

${ }^{858}$ N. BOSCHIERO, La lex mercatoria nell'era della globalizzazione ..., p. 146. 
direito $^{859}$, considerando a nova lex mercatoria como expressão de juridicidade da societas mercatorum, que comporta tanto uma dimensão transnacional quanto local.

A societas mercatorum, business community, mercatocracy ou classe mercantil, é formada por Estados, organizações e organismos internacionais, ONGs e empresas transnacionais, entidades profissionais de caráter coletivo e os prestadores de serviços jurídicos e contábeis. $\mathrm{O}$ elemento de coesão são os interesses comuns relacionados às necessidades do comércio internacional, geridos por organizações internacionais, organizações intergovernamentais e entidades privadas de caráter coletivo, sejam entidades profissionais ou outras organizações não governamentais, com destaque para a CCI.

A nova lex mercatoria pode ser entendida, dessa forma, também como mentalidade ${ }^{860}$. Portanto, pode servir finalidades ou interesses distintos ${ }^{861}$. Por um lado, como instrumento para superar as barreiras estatais e favorecer o comércio internacional. Por outro, como veículo da societas mercatorum para prevalecimento de interesses econômicos mediante a privatização da produção de regras jurídicas às vezes sem a representatividade ou legitimidade para tanto, a fim favorecer interesses econômicos. Assim, na prática, o denominador comum - necessidades do comércio internacional - pode coincidir com o puro e simples interesse econômico. Pode se exercer autoridade privada para fazer da nova lex mercatoria mero economismo.

Os impactos adversos da mais recente crise econômica parecem ter deixado tal aspecto evidente. Assim como não é correto afirmar que nova lex mercatoria substituirá os Estados ${ }^{862}$, também não parece porém razoável afirmar que os Estados re-assumirão por completo o espaço ocupado pela nova lex mercatoria, privilegiando ou tentando retomar uma concepção monista do direito, com o conseqüente desaparecimento da

\footnotetext{
${ }^{859}$ F. OSMAN, Les principes généraux..., p. 455, p. ex., “il s'agit ni plus ni moins que d'une manifestation contemporaine du pluralisme juridique".

${ }^{860}$ A. GAMBARO, Alcuni appunti sugli aspetti istituzionali della cosidetta globalizzazione, in Sociologia del Diritto, v. 32, n. 2-3, 2005, p. 247. V. OlgIATI, Lex mercatoria e communitas..., p. 360, por sua, vez afirma que "l'odierno revival della stella Lex Mercatoria può agevolmente essere inteso... come un fenomeno di insurgency normativa, datta la irreducibile differenza, insofferenza ed estraneità rispetto ai vincoli imposti dall'ordine giuridico formale-ufficiale". Ou seja, recordando F. GALGANO, Lex mercatoria..., pp. 12-3, mais do que um ramo do direito, a lex mercatoria significa um modo de criá-lo.

${ }^{861}$ Como destaca A. C. Cutler, Private Power..., p. 261, "reconceiving transnational merchant law as praxis thus involves recognizing the historic effectivity of the law in its material, ideological, and institutional dimensions. Transnational merchant law has served different interests and purposes over history".

${ }^{862}$ B. DE S. SANTOS, law - A Map of Misreading..., p. 298, ressalta que "in a polycentric legal world the centrality of the state law, though increasingly shaken, is still a decisive political factor"
} 
nova lex mercatoria ${ }^{863}$. Certo, haverá (e deveria havê-la) maior intervenção dos Estados. Mas, assim como o saldo da nova lex mercatoria nos dias atuais, também os resultados pelo Estado não estão imunes a críticas. Por isso, talvez seja o caso de interpretar o fenômeno como parte de um processo histórico, dialético do desenvolvimento desse ramo do direito. $\mathrm{O}$ esquema proposto pela modernidade do direito, tese. A nova lex mercatoria como expressão preponderantemente econômica e operando em favor dos mais fortes, assim como apontado pelos seus mais severos críticos, antítese. Busca-se a síntese, que por sua vez, em resposta às necessidades evolutivas da sociedade, buscará novo equilíbrio, e assim por diante ${ }^{864}$.

O desaparecimento da nova lex mercatoria parece muito menos provável do que sua consolidação e expansão. A exigência de ampliação e unificação dos mercados, entendida como a ausência de fronteiras (e não unificação política) é uma constante do comércio, que o acompanha desde a antigüidade. O comércio, e assim também o direito comercial internacional, naturalmente se aspira cosmopolita. Assim, em resposta a tal anseio, a criação de um direito privado material transnacional é razoável. O essencial é corrigir seu curso a fim de garantir co-existência harmoniosa com a ordem estatal e a ordem internacional.

Mas, para tanto, sua não pode ser feita sob a perspectiva clássica. $\mathrm{Na}$ sociedade pós-industrial, o direito assume também outras características, a respeito das quais a consciência é imprescindível.

Como fenômeno jurídico, a nova lex mercatoria é uma das expressões do direito na sociedade pós-industrial. Muitas vezes, é identificada como direito global ou com o direito da globalização ${ }^{865}$.

\footnotetext{
${ }^{863}$ E por isso re-politização da nova lex mercatoria, embora necessária, deve ser vista com cautela. $\mathrm{O}$ essencial, mais do que re-politizar ou não, é como fazê-lo.

${ }^{864}$ M. DELMAS-MARTY, Les forces imaginantes du droit..., pp. 397, observa que "le droit nécessite donc des synthèse, même si celles-ci doivent rester modestes, provisoires, ni à une vérité qui serait désormais immuable et définitive".

865 Vide, por exemplo, G. Teubner, 'Global Burkowina'.... Segundo V. Olgiati, Lex mercatoria e communitas..., pp. 367-8 "di qui dunque la lotta a tutto campo per la 'investitura' ufficiale - il riconoscimento delle corporazioni economiche quali vere e proprie istituzioni - tale da Poter imporre autonomamente la regione sociale della propria mission con una forza cogente ed un appeal ideologico indiscutibile perchè, appunto, legittimo. All'interno di questo scenario ora descritto si stua senz'altro anche l'utilizzo strumentale della Lex Mercatoria... Tanto è vero che si scorre la letteratura sociogiuridica orientata a sostenere l'ipotesi della globalizzazione, in generale, della globalizzazione del diritto, in particolare, la Lex Mercatoria appare come il campo nel quale i giuristi della Communitas Mercatorum operano come veri e propri moral entrepeneurs, così creando le condizioni più congruenti - dealing with virtue - per prmovere un nuovo ordine mondiale finalmente centrato sui valori imperativi del mercato. Di conseguenza, non può sorprendere che la stessa Lex sia altresì continuamente richiamata comme esempio più computo ed evidente di global law".
} 
Como observado ${ }^{866}$, o direito global, porém, como um fenômeno único, unificado, não existe na realidade ${ }^{867}$. Se a expressão for entendida como um gênero, assim como direito transnacional, pode ajudar a compreender as espécies ou expressões desse direito, como a nova lex mercatoria. O mesmo vale para a expressão direito da globalização.

Além disso, considerando que uma parte da criação se desloca do centro à periferia - entendida como fonte normativa e cognitiva que se situa na fronteira com a sociedade, a economia ${ }^{868}$, os fatos - novos meios de legitimação democrática devem surgir.

A tecnocracia, atuando como verdadeiro filtro cultural (assim os Princípios UNIDROIT, os contratos-tipo e demais instrumentos elaborados pela CCI, por exemplo) é certamente útil nessa tarefa. Contudo, não é suficiente.

Assim, a questão permanece não resolvida. Cabe, em realidade, cuidar para que a societas mercatorum não se reduza à expressão unilateral dos interesses das empresas transnacionais. Recorde-se que a societas mercatorum não é composta apenas das grandes empresas transnacionais. A seu lado, figuram os Estados, as organizações internacionais, organizações intergovernamentais e entidades privadas de relevância coletiva ou pública, além de outros entes privados.

Esses demais membros da business community devem considerar que a nova lex mercatoria expressa, tal qual o direito na sociedade pós-industrial, um work in progress, open-ended. Assim, consiste mais em processo do que em procedimento e constitui instrumento de comunicação fundamental ${ }^{869}$. Isto é, é função essencial sua comunicar, circular as informações, estabelecer diálogos, processos de formação de consenso, das trocas.

\footnotetext{
${ }^{866}$ Vide item n.r. 103.

${ }^{867}$ F. CASUCCI, Il diritto 'plurale'..., p. 29 e V. OlgIATI, Lex mercatoria e communitas..., p. 368. OlgIATI afirma que "la... Lex Mercatoria non può essere affato indicata come un modello di 'diritto globale', o la prova provata della 'globalizzazione del diritto' per il semplice fatto che queste definizioni sono tanto fantasiose, quanto prive di riscontro empirico".

${ }^{868} \mathrm{Na}$ perfireria ocorre a transformação jurídica das relações econômicas. O centro seria a produção arbitral e associativa, cf. G. TEUBNER, Breaking Frames, p. 32.

${ }^{869}$ M. R. FERRARESE, Le istituzioni della globalizzazione..., pp. 62-3. Identificar o direito com um processo implica afirmar que o direito não é resultado de seqüência formalizada de etapas, o que levaria à idéia de um produto acabado. Como processo, o direito está constantemente se desconstruindo e reconstruindo, por meio de múltiplos impulsos, em vários níveis e provenientes de atores diversos. M. R. FERRARESE (pp. 143-5) salienta que a idéia típica de "procedimento" é aquela de "'sequenza formalizzata di tappe che conducono a um esito definitivo, certo e accertabile". Assim, para a autora "il diritto, pensato come 'procedimento' era innazitutto una riserva di legittimità perchè rimandava a una decisione e persino una pretesa si verità... Ma il procedimento era anche garanzia... di compiutezza... Ora, non si può dire che il diritto globale abbia perso ogni legame con il procedimento.... Ma esso non sembra promettere grandi ritorni all'idea pura di procedimento".
} 
Por isso, para que a nova lex mercatoria não se reduza a mero economismo ${ }^{870}$, esses demais membros da societas mercatorum devem se conscientizar dos interesses públicos ou coletivos, identificáveis com a sociedade civil transnacional, que permeia os contratos comerciais internacionais. E, assim, esses outros participantes devem exercer um papel mais ativo para estabelecer diálogos e processos dialéticos de legitimação.

DELMAS-MARTY observa que é da "figure du triangle des acteurs, public, privés et civils (neste contexto, membros da societas mercatorum)", isto é, "c'est de la pluralité des acteurs et de la cohérence de leur action que naîtra la possibilité d'un ordre mondial non hégémonique. On retrouve ici, même s'il s'agit d'une notion très polysémique, voire d'un myth, la notion de société civile. Placée entre les pouvoirs politiques publics et les pouvoirs privés économiques, la société civile conçue comme un 'milieu', à la fois un centre et un entre-deux, relie alors, plus qu'elle n'oppose, les deux sphères"

Além disso, devem levar em conta que o contrato na sociedade pós-industrial assume função normativa e deve transcender a esfera puramente individual ${ }^{872}$. Segundo BOSCHIERO, mais do que buscar garantias contra o exercício abusivo da autonomia em um mercado regulado pelos poderes públicos, deve-se concentrar nos parâmetros de justiça e equilíbrio em relação ao próprio contrato, já que, para ela, o mercado seria o resultado global da autonomia privada que encontra expressão mediante os contratos ${ }^{873}$. Para BosCHIERo trata-se, assim, de tradução normativa na nova lex mercatoria de um princípio de justiça contratual $^{874}$.

${ }^{870}$ L. Pannarale, Delocalizzazione del diritto..., p. 326, observa que "la sottrazione di spazi comunicativi ai condizionamenti dell'economia si dimostra affatto indispensabile per evitare il rischio che venga meno la fiducia nella possibilità di comunicare liberamente e ogni messaggio appaia sospetto, determinato da interessi di tipo esclusivamente o almeno prevalentemente economico, bisognoso di essere filtrato attraverso estenuanti processi di decriptazione, in mancanza dei quali la coisa più sensata si rivela il sceticismo metodologico".

${ }^{871}$ M. DELMAS-MARTY, Les forces imaginantes du droit..., p. 327.

${ }^{872}$ Evoca-se, assim, a cooperação juntamente com a troca, recriando um diálogo simultâneo com a justiça distributiva e com a justiça comutativa.

${ }^{873}$ N. BOSCHIERO, La lex mercatoria nell'era della globalizzazione ..., p. 133. Segundo BosChIERO, a presunção de fraqueza só dos consumidores é superada pela experiência contratual da nova lex mercatoria. "essendo ormai pacifico che la mera qualità di imprenditore non è più idonea di per sé oggi a rendere gli operatori del commercio inter- (o) transnazionale immuni da eventuali vessazioni negoziali", cabendo aos árbitros e juízes o direito e o dever de avaliar se a autonomia é abusiva e, neste caso, reconstruir a relação contratual.

${ }^{874}$ N. Boschiero, La lex mercatoria nell'era della globalizzazione ..., p. 139: "si tratta pertanto della traduzione normativa a livello di lex mercatoria di un principio generale di giustizia contrattuale che si risolve in limiti stringenti all'autonomia inibendo le pratiche contrarie al buon costume economico e indiscutibilmente distorsive, principio che è stato ulteriormente rafforzato da istituti (per così dire 'endogeni' alla lex mercatoria stessi) di etica civile di mercato (quali l'ipotesi di rescissione per lesione enorme o per stato di pericolo, il divieto di intese restrittive della concorrenza e l'abusi di posizione 
Como já salientado, o conceito de pluralismo jurídico - a partir de concepção, não mais apenas de espaços geográficos, mas também de diferentes espaços jurídicos sobrepostos, interpenetrados e misturados - é fundamental para compreensão do direito na sociedade pós-industrial ${ }^{875}$.

Como consequiência do pluralismo jurídico, a vida jurídica é constituída, segundo SANTOS, de uma intersecção de ordens jurídicas diferentes, denominada de interlegalidade ${ }^{876}$.

A interlegalidade deve conduzir e refletir um equilíbrio entre a economia, a sociedade e a política. Aponta OlgIATI que a "lex mercatoria... è un modello sui generis di "interlegalità", mas ocorre que, atualmente, "infatti, ciò che davvero conta per la Communitas Mercatorum è sempre stato ed è, appunto, la dinamica del contesto sociale: tanto della aspettative quanto dei rapporti di forza" ${ }^{\text {877 }}$. A correção do curso da nova lex mercatoria está, portanto, no reequilíbrio da interlegalidade ou - na linguagem de TEUBNER - no seu acoplamento equilibrado não só com processos econômicos economia, como atualmente, mas também com os processos políticos e sociais ${ }^{878}$.

E, para tanto, é necessário reforçar o particularismo e caráter limitado da nova lex mercatoria e enfatizar o modo com que deve co-existir com a ordem estatal e internacional, bem como com a proteção de direitos humanos, do meio-ambiente e de outros direitos inalienáveis.

Em relação ao Estado, tem relação complementar e não alternativaa ${ }^{879}$ : são relações de independência, autonomia, complementaridade integração e também de concorrência ${ }^{880}$. Salienta LOQUIN, "une analyse attentive de la lex mercatoria montre que celle-ci se nourrit des ordre juridiques étatiques" ${ }^{\text {} 81}$. Não só absorvem de certa forma suas normas, que são transnacionalizadas, mas também deles extraem força

dominante), che oggi risultano codificati in meccanismi di autodisciplina, codici di condotta, norme di business ethics, che pongono limiti di natura interna all'autonomia privata, sostituendosi agli stessi pubbilici poteri nella protezione di interessi di carattere generale dell'intera colletività mercantile".

${ }_{875}$ B. DE S. SANTOS, law - A Map of Misreading..., p. 298.

${ }^{876}$ B. DE S. SANTOS, law - A Map of Misreading..., p. 298. Segundo BoAventura DE Sousa SANTOS, uma vez que os espaços jurídicos distintos não são sincrônicos, o modo pelo qual a interlegalidade é realizada consiste em um processo dinâmico.

${ }^{877}$ V. OLGIATI, Lex mercatoria e communitas..., p. 364.

${ }^{878}$ Vide, por exemplo, G. TEUBNER, 'Global Burkowina'....

879 A. FRIGNANI, L'arbitrato commerciale internazionale..., p. 139. P. KAHN, Droit international économique..., pp. 106-7, observa que "tous les rapports ne sont pas de subordination ou d'hostilité mais aussi de coopération".

${ }_{880}^{80}$ D. TERRE, Le pluralisme et le droit..., p. 77.

${ }^{881}$ E. LoQuin, Où en est la lex mercatoria?..., p. 27. 
coercitiva, principalmente por meio da arbitragem ${ }^{882}$. Como recorda MARRELLA, "a garanzia dell'efficacia della nuova lex mercatoria contribuiscono potentemente gli stessi Stati, giacchè, rinunciando a disciplinare il commercio internazionale, spingono, ipso facto, gli operatori ad elaborare delle regole per disciplinare direttamente i loro rapporti. Si può ravvisare dunque, in questo contesto, un fenimeno jellinekiano di autolimitazione dello Stato, una sorta di self-restraint cui corrisponde l'autoregulamentazione del ceto degli affari", 883

Em contrapartida, como salienta OSMAN, por reciprocidade e cooperação, a nova lex mercatoria deve contribuir ao respeito da ordem pública estatal, refletida na intervenção dos árbitros em razão das leis de aplicação necessária ${ }^{884}$.

A reflexão a respeito da relação da nova lex mercatoria com a ordem internacional, com o direito internacional, é a que mais pode contribuir para a viabilidade da nova lex mercatoria.

Primeiro, a caracterização das empresas transnacionais efetivamente como sujeitos (e não só por intermédio dos respectivos Estados) e não objeto talvez possa conduzir a resultados positivos. De acordo com CUTLER, a proliferação de relações inter-company indiretamente mina a autoridade dos Estados, Além disso, a atuação transnacional das empresas dá ensejo a um grande problema normativo de responsbilização dessas empresas. De maneira geral, o Estado dificilmente estará disposto a assumir a responsabilidade por delas, até porque não tem como garantir a nacionalidade das empresas ${ }^{885}$.

Por isso, com o reconhecimento da capacidade jurídica das empresas transnacionais no direito internacional, criando direitos, obrigações e responsabilidades, inclusive junto aos Estados, parece ser favorável. Propicia a criação de espaços

\footnotetext{
${ }^{882}$ P. LAGARDE, Approche critique..., p. 146.

${ }^{883}$ F. MARRELLA, La nuova lex mercatoria tra controversie..., p. 251, n. 7.

${ }^{884}$ F. OSMAN, Les príncipes généraux..., 456. P. KAHN, Droit international économique..., pp. 106-7, afirma que "tout d'abord il faut que les règles impératives existent... Il faut ensuite qu'il y ait des points de contact, des points de rencontre entre les ordres (comunidade internacional - ordem pública econômica internacional) ... Les points de contat sont don numbreux et l'ordre étatique et interétatique pourrait s'imposer beaucoup plus qu'il ne fait sans bouleversement des règles de droit".

885 A. C. CUTLER, Private Power..., pp. 202-3. Segundo CUTLER "emphasis on the legal aspects of the corporate personality risks a formalism that mistakes the legal form for the actual conduct and practices of corporations and of states. It also risks obscuring how corporations use their nationality to avoid or evade responsibility".
} 
comunicativos e estabelecimento de diálogos entre as empresas e os demais atores da nova lex mercatoria, buscando novos caminhos de legitimidade ${ }^{886}$.

É por meio do direito internacional que consecução de um equilíbrio entre os processos sociais, políticos e econômicos é possível.

A lex mercatoria é subordinada ao direito internacional, destaca VIRALLY ${ }^{887}$. Os interesses superiores - a que LOQUIN ${ }^{888}$ se refere - que devem ser observados pela nova lex mercatoria são aqueles estabelecidos pela ordem internacional. Isto porque, como recorda KAHN, "la Communauté internationale représentant des solidarités beaucoup plus larges, beaucoup plues intense que la solidarité de l'ordre mercatique, on peut affirmer que son droit dans ses éléments fondamentaux constitue un droit d'application immédiate, qui brise toute autre tentative d'établir une règle de droit different et concurrente..." ${ }^{889}$.

A nova lex mercatoria deve, primeiro, fundar novos meios de legitimação em relação a seu conteúdo. E, mais do que isso, reforçar o respeito ao ius cogens tanto por meio dos princípios gerais, como pela intervenção em nome da ordem pública internacional, mais do que da transnacional. Nos últimos anos, a jurisprudência arbitral tem se mostrado sensível às demandas da ordem internacional. Não têm as câmaras arbitrais legitimidade, porém, para fazê-lo por conta própria - até por uma questão de fundamentação e previsibilidade do próprio laudo.

Resta, assim, reforçar a construção do direito internacional ${ }^{890}$. Tal como sugere MARTY, "pour garantir la previsibilitè d'un... droit à textures múltiples, allant du droit dur au droit souple il serait en outro nécessaire d'apprendre à utiliser toute le palette des logiques: la logique binaire classique quand'il s'agit de concepts durs (e.g. direitos humanos, meio-ambiente), comme les droits indérogeables ou plus largement le jus cogens; ..... ${ }^{, 891}$. À construção da nova lex mercatoria como direito das possibilidades, impõe-se a composição dos atores públicos, privados e sociedade civil para a construção

\footnotetext{
${ }^{886}$ A título exemplificativo, a fim de construir um diálogo para obtenção de consenso em relação a um código de conduta das empresas transnacionais. Vide, a respeito das iniciativas para tanto, como as da OECD, A. C. Cutler, Private Power..., p. 200 e P. T. MuCHlinski, Global Burkowina Examined..., pp. 94 e ss.

${ }^{887}$ M. VIRALLY, Un tiers droit?..., p. 385. No mesmo sentido, F. OSMAN, Les principes généraux..., pp. 457-8 e N. BOSCHIERO, La lex mercatoria nell'era della globalizzazione ..., pp. 143-4.

${ }^{888}$ E. LoQUIN, Où en est la lex mercatoria?..., p. 50.

${ }^{889}$ P. KAHN, Droit international économique..., pp. 106-7.

${ }^{890}$ N. BOSCHIERO, La lex mercatoria nell'era della globalizzazione ..., p. 146. Segundo L. PANNARALE, Delocalizzazione del diritto..., p. 325, o primeiro passo é o reequilíbrio interno dos organismos internacionais, políticos e econômicos. Para ele, "anche a livello internazionale occorre avere il coraggio di passare da un sistema di tipo oligarchico ad un sistema di tipo democratico".

${ }^{891}$ M. DELMAS-MARTY, Les forces imaginantes du droit..., pp. 413-4.
} 
e consolidação de uma ordem das necessidades ${ }^{892}$ a fim de evitar a monetização ou mercantilização dos direitos ${ }^{893}$.

O direito internacional deve do alargar o rol de direitos indisponíveis, inalienáveis, seja com o aprofundamento dos direitos humanos e do meio-ambiente, seja com o reconhecimento de novos direitos, e com o estabelecimento e regulação de uma estrutura, um framework de desenvolvimento da nova lex mercatoria ${ }^{894}$, dando a medida de compatibilidade entre o local e o global, entre o duro e o mole. $\mathrm{O}$ direito internacional deve alargar o rol de direitos indisponíveis e inalienáveis, seja a partir do aprofundamento dos direitos humanos e do meio-ambiente, seja a partir do reconhecimento de novos direitos.

\footnotetext{
${ }^{892}$ M. R. FERRARESE, Le istituzioni della globalizzazione..., p. 152.

${ }^{893}$ L. PANnARAle, Delocalizzazione del diritto..., p. 324, reafirma a necessidade de "porre dei limiti non valicabili alla monetizzabilità o alla mercificazione di alcuni diritti, non solo nel senso... di allungamento della lista di diritti indisponibili e inalienabili, bensì anche nel senso di una allocazione e distribuzione di determinati beni e diritti secondo modalità che prescindano da qualsivoglia considerazione di tipo economico e impognano la loro assoluta gratuità. Inoltre occorrerebbe configurare tali diritti non più soltanto come diritti individuali, ma piuttosto come diritti di cui sono titolari i popoli"

${ }^{894}$ Por exemplo, M. R. FERRARESE, Le istituzioni della globalizzazione..., pp. 36-38 e pp. 221-2, salienta que as crises relacionadas ao mercado financeiro são resultado de uma série de não-decisões, principalmente dos EUA. Com a desmaterialização e volatibilidade da propriedade e da moeda, a especulação (incerteza) passa a ocupar uma posição importante. São criadas, assim, novas formas entre racionalidade e risco, a que o direito deve responder. $\mathrm{O}$ direito pode ser visto, sob tal perspectiva, como meio de transferência de risco. O risco não é mais questão política, como antigamente. Interessante notar a criação recente do European Journal of Risk Regulation. E talvez seja esse também um caminho a ser percorrido pelo direito internacional.
} 


\section{CONCluSÃo}

A transição da sociedade industrial à sociedade pós-industrial, moldada pela globalização, conduz a perspectivas jurídicas que vão além da concepção do fenômeno jurídico na modernidade, razão pela qual considera-se útil recorrer à teoria pós-moderna como ponto de partida.

Assim, as características do direito da sociedade pós-industrial que este trabalho buscou destacar são aquelas, inéditas ou não, que diferenciam o direito com o qual a sociedade ocidental, especialmente aquele conjunto de países cujo sistema jurídico é de tradição romano-germânica, está habituada há dois ou três séculos. Observe-se, porém, que a sociedade pós-industrial se desenvolve mais pela continuidade do que pela ruptura das instituições, razão pela qual as características da sociedade pós-industrial não sucedem ou substituem definitivamente aquelas da sociedade moderna, mas apenas com elas convivem.

A perspectiva iluminista e juspositivista do direito sedimentou uma noção territorializada e oficial do direito, que a sociedade pós-industrial pretende revisitar e ir além.

O contexto jurídico da sociedade pós-industrial é preenchido pela pluralidade de ordens jurídicas (de escopo limitado ou não, completas ou não) fundadas em espaços geográficos, políticos ou também jurídicos (transnacionais ou não, assim como as comunidades de que são expressão).

A intersecção entre essas ordens jurídicas (interlegalidade, segundo SANTOS ${ }^{895}$ ) revela relações de independência, autonomia, complementaridade integração e também concorrência.

A redefinição das fronteiras jurídicas altera as esferas de relevância pública e, com isso, a soberania dos Estados - o que não implica seu desaparecimento, ao contrário. O sentido dessa alteração não é unidirecional. Isto é, em alguns contextos a soberania dos Estados aumenta, em outros diminui -verificação esta que depende de uma análise caso a caso.

Reconhecidas a pluralidade de ordens jurídicas, a reconfiguração da soberania dos Estados e a reorganização das fontes do direito, a noção de autoridade (isto é, ente apto a criar e aplicar as regras jurídicas) deve ser reavaliada. A concepção de autoridade

${ }^{895}$ B. DE S. SANTOS, law - A Map of Misreading ..., p. 298. 
como construção social leva à conclusão de que existe autoridade além do Estado. Isto não significa que o Estado deixa de existir, de produzir e aplicar regras, e deixa de exercer papel fundamental no contexto atual, sendo importante fonte de legitimidade.

Além das autoridades que se situam acima dos Estados (supranacionais), existem outras a seu lado (como a ordem eclesiástica ou a nova lex mercatoria), cuja condição é baseada no reconhecimento como tal pelo próprio grupo social.

Esse quadro indica um entrelaçamento profundo entre esferas públicas e privadas, que torna difícil a distinção entre direito público e privado. Esta distinção, aliás, existe de forma mais nítida apenas a partir da modernidade e, mesmo assim, não é comum a todos os sistemas jurídicos. Direito público e privado permeiam-se cada vez mais.

O direito da sociedade pós-industrial é um direito que está se fazendo e refazendo constantemente. É, assim, open-ended, work in progress e, por isso, mais processo que procedimento (embora ambos coexistam). É um direito que valoriza, ao lado das esferas formais, as esferas informais, com impulsos espontâneos e organizados, orais e escritos. Revela-se, assim um direito mais horizontal, plural, factual, em rede, do que outrora. O direito, assim, é constituído de múltiplas texturas. Uma delas mostra que o direito é também um produto negociável, isto é, fruto de consenso entre os participantes. Nesse contexto, o papel criador e inventivo dos juízes ganha relevância e segurança e certeza do direito, como propostas no direito moderno, são revisitadas.

O grande desafio desse direito é superar o déficit democrático, isto é, construir uma ordem jurídica que não penda para forças econômicas ou políticas, mas que proporcione harmonia, equilíbrio entre esses processos e os processos sociais.

Este contexto de intersecção de ordens jurídicas e, à luz daquelas outras características do direito, conduz o direito a Hermes, o mediador universal, o grande comunicador. Circulação das informações e de diálogos, novos meios para construção de consensos e de trocas são assim dados aos quais o direito deve responder.

Esse quadro teórico do direito na sociedade pós-industrial conduz à concepção da nova lex mercatoria como um direito material transnacional, cujas regras são formadas pela própria business community, com maior ou menor grau de espontaneidade e aplicáveis aos contratos comerciais internacionais (não regulando, por ora ao menos, temas como capacidade das partes, vícios de consentimento e transferência de propriedade). 
As fontes normativas da nova lex mercatoria são três. A primeira, que aliás garante o caráter dinâmico desse direito transnacional, são os usos comerciais - quer sejam formulados ou não-formulados - compreendidos em larga escala pelas práticas contratuais (e.g. contratos-tipo e cláusulas-padrão) desde que fundadas na consciência, pelos membros da societas mercatorum, da juridicidade de que determinada prática se adequa às necessidades do comércio internacional (opinio iuris).

A segunda fonte e núcleo duro da nova lex mercatoria são os princípios gerais, sejam os princípios gerais de direito deduzidos a partir do artigo 38 do estatuto da Corte Internacional de Justiça, sejam princípios gerais específicos da nova lex mercatoria. Estes princípios são próprios do novo ius mercatorum porque, mesmo se existentes em um ou mais direito(s) nacional(is), são objeto de uma transnacionalização e recepção pela nova lex mercatoria. Entre esses princípios, merece destaque a boa-fé objetiva, que atua como sobreprincípio. Os Princípios UNIDROIT são a mais importante e completa fonte de cognição desses princípios gerais.

Por fim, a nova lex mercatoria se apóia nos precedentes arbitrais que, extraindo, evidenciando e enunciando os princípios gerais e os usos, são utilizados de referência para (e por) decisões futuras, formando uma jurisprudência arbitral, cuja estrutura e características são diferentes daquelas da jurisprudência formada pelos tribunais estatais.

Além disso, a nova lex mercatoria está sujeita à ordem pública. Primeiro, os contratos são desnacionalizados (desterritorializados) ao optarem pela nova lex mercatoria. Mas a desterritorialização é limitada. Os contratos são obrigatoriamente (re-)nacionalizados (re-territorializados) ao serem executados em um determinado Estado. Estão, assim, sujeitos às leis de aplicação necessárias. A nova lex mercatoria, assim, não se pretende supranacional (é de escopo limitado a determinados aspectos do comércio internacional).

Além disso, a nova lex mercatoria é limitada pela ordem pública transnacional, que reflete valores próprios do comércio internacional (e.g. anulação de contratos que têm por fim a corrupção).

A nova lex mercatoria também é sujeita à ordem pública internacional, ao ius cogens.

A nova lex mercatoria, à semelhança do direito internacional, constitui ordenamento jurídico autônomo - o que não impede a influência de outras ordens jurídicas em seu desenvolvimento. 
A societas mercatorum ou business community é uma comunidade de interesses (e não de lugar) fundada nos interesses comuns relacionados às necessidades do comércio internacional. É formada por atores públicos, privados e pela sociedade civil (Estados, organizações e organismos internacionais, ONGs e empresas transnacionais, entidades profissionais de caráter coletivo e os prestadores de serviços jurídicos e contábeis).

A utilização da nova lex mercatoria pode reduzir custos de transação (informação) na medida em que, como direito aplicável principal ou como filtro cultural, pode afastar as especificidades e tecnicalidades dos direitos nacionais que não correspondam às expectativas dos operadores do comércio internacional. Os custos de transação (informação) da utilização da própria nova lex mercatoria tendem a diminuir com o seu desenvolvimento e também com a consolidação e acessibilidade de suas fontes cognitivas.

Mas, por outro lado, a aplicação da nova lex mercatoria pode levar a resultados indesejados sempre que expressar apenas os interesses econômicos dominantes em detrimento de outros interesses a serem protegidos e que tocam o restante da sociedade (os interesses econômicos não coincidem exatamente com as necessidades do comércio internacional, que abrangem também valores non marchands ${ }^{896}$ ). As crises econômicas comprovam como a nova lex mercatoria pode ter efeitos negativos.

Mesmo assim, é provável que a lex mercatoria continue a existir, na medida em que a premência de diminuir a fragmentação política e jurídica do comércio internacional persiste. Resta, então, cuidar para que esse direito transnacional se torne viável, isto é, que se desenvolva em harmonia com o restante da sociedade.

A produção privada de regras jurídicas conduz a uma crise de legitimidade democrática que a tecnocracia (p. ex. filtro cultural dos juristas, como na formação dos Princípios UNIDROIT) pode amenizar, mas não resolver.

Para tanto, todos os membros da business community - e não só as empresas transnacionais - devem se conscientizar de um direito que tem sínteses provisórias, que está sempre se reconstruindo e que, para tanto, depende do estabelecimento de processos comunicativos (circulação de informações, estabelecimento diálogos, processos de formação de consenso e das trocas). Devem também identificar o interesse coletivo, a relevância pública do direito privado e das relações comerciais

\footnotetext{
${ }^{896}$ M. DELMAS-MARTY, Les forces imaginantes du droit..., p. 154.
} 
internacionais. Na sociedade pós-industrial, o contrato deve transcender a esfera puramente individual.

O curso da nova lex mercatoria deve ser corrigido para que ela reflita um equilíbrio entre a economia, a sociedade e a política. É necessário reconhecer seu escopo específico e seus limites para que desenvolva relações harmônicas com a ordem estatal e internacional e seja compatível com a proteção de direitos humanos, do meioambiente e de outros direitos inalienáveis.

Para tanto, é preciso enfatizar a relação de subordinação que a nova lex mercatoria guarda em relação à ordem internacional.

Assim, além da caracterização das empresas transnacionais efetivamente como sujeitos de direito internacional, imputando-lhes, diretamente, direitos e obrigações (e, portanto, responsabilidade) nessa esfera, a noção de ordem pública internacional (ius cogens) deve ser fortalecida pela ampliação dos direitos indisponíveis (e.g. aprofundamento dos direitos humanos e do meio-ambiente e reconhecimento de novos direitos).

Assim, os árbitros terão fundamentos para, aplicando a nova lex mercatoria, proporcionar soluções mais adequadas ao equilíbrio social, afastando determinados valores econômicos quando contrários ao ius cogens. Um tal desenvolvimento não significa que a nova lex mercatoria, por seu turno, deva produzir novos meios de legitimação de seu conteúdo.

A um direito de texturas múltiplas, devem corresponder lógicas também múltiplas. O direito (e também a nova lex mercatoria, portanto) deve saber construir e distinguir, ao lado de um direito das possibilidades, uma ordem das necessidades que filtre interesses de natureza puramente econômica e conduza a um ambiente mais equilibrado. 


\section{BIBLIOGRAFIA}

ANCEL, Bertrand, The Tronc Commun Doctrine - Logics and Experience in International Arbitration, in Journal of International Arbitration, 1990, pp. 65-72.

ARAÚJO, Nádia de, A Nova Lei de Arbitragem e os "Princípios Uniformes dos Contratos Comerciais Internacionais", elaborados pelo UNIDROIT, in CASELLA, Paulo Borba (coord.), Arbitragem - Lei Brasileira e Praxe Internacional, $2^{\mathrm{a}}$ ed., São Paulo, LTr, 1999, pp. 133-62.

ARNAUD, André Jean, Entre modernité et mondialisation - Leçons d'histoire de la philosophie du droit et de l'Etat, $2^{\mathrm{a}}$ ed., Paris, LGDJ, 2004.

ATIYAH, Patrick Selim, The rise and fall of freedom of contract, New York, Oxford, 1985.

AZEVEDO, Luiz Carlos de, Introdução Histórica do Direito, São Paulo, Revista dos Tribunais, 2005.

BAPTISTA, Luiz Olavo, "O Projeto de princípios para Contratos Comerciais internacionais da UNIDROIT - Aspectos de direito internacional privado, in BONELL, Michael Joachim e CHIPANI, Sandro (org.), Il Progetto UNIDROIT "Principi per $i$ contratti commeciali internazionali" e l'unità e speificità del sistema giuridico latinoamericano, Padova, Cedam, 1996, pp. 23-33.

BART, Jean, La lex mercatoria au moyen age - mythe ou realitè?, in LEBEN, Charles; LOQUIN, Eric; SALEM, Mahmoud (org.), Souveraineté étatique et marchés internationaux à la fin du 20ème siècle, à propos de 30 ans de recherche du CREDIMI - mélanges en l'honneur de Philippe Kahn, Paris, Litec, 2000, pp. 10-22.

BASEDOW, Jürgen, International Uniform Law Conventions and the UNIDROIT Principles of International Commercial Contracts, in Uniform Law Review, 2000, pp. 129-39.

BASSO, Maristela, A Autonomia da Vontade nos Contratos Internacionais de Comércio, in Direito e Comércio Internacional - Tendências e Perspectivas - Estudos em Homenagem ao Professor Irineu Strenger, São Paulo, LTr, pp. 42-62. Âmbito de Aplicação dos Princípios UNIDROIT sobre os Contratos Comerciais Internacionais, in Revista Jurídica UNIGRAN, 1999, pp. 48-57. 
Contratos Comerciais do Comércio - Negociação, Conclusão,

Prática, 2a ed., Porto Alegre, Livraria do Advogado, 1998.

, Curso de Direito Internacional Privado, São Paulo, Atlas, 2009.

BAXTER, R. R. International Law in "Her Infinite Variety", in International and Comparative Law Quarterly, v. 29, 1980, pp. 549-566.

BERGER, Klaus Peter, The concept of the “creeping codification” of transnational commercial law, cf. disponível [on-line] in www.Trans-Lex.org/000004 [15.12.2009].

, The creeping codification of the lex mercatoria, The Hague,

Boston, Kluwer Law International, 1999.

, The relationship between the UNIDROIT Principles of

International Commercial Contracts and the new lex mercatoria, in Uniform Law Review, 2000, pp. 153-70.

BERGER, Peter L., LUCKMANN, Thomas, Modernität, Pluralismus und Sinnkrise Die Orientierung des modernen Menschen, trad. port. de Edgar Orth, Modernidade, Pluralismo e Crise de Sentido - A Orientação do Homem Moderno, Petrópolis, Vozes, 2004.

BERMAN, Paul Schiff, From international law to law and globalization, in Columbia Journal of Transnational law, v. 43, n. 2, 2005, pp. 485-556.

BERMAN, Harold J.; KAUFMAN, Colin, The Law of International Commercial Transactions (Lex Mercatoria), in Harvard International Law Journal, Cambridge, 1978, pp. 221-77.

L. BeRnsteIn, Opting out of the Legal Sytem - Extralegal Contractual Relations in the Diamond Trade, in Journal of Legal Studies, pp. 115-57;

, Private commercial law in the cotton industry - creating cooperation through rules, norms and institutions, in Michigan law Review, 2001, pp. 1724-90.

BOBBIO, Norberto, Da Estrutura à função - novos estudos de teoria do direito, São Paulo, Manole/Bovespa, 2006.

Il positivismo giuridico, trad. port. de Márcio Pugliesi, Edson

Bini, Carlos E. Rodrigues, O Positivismo Jurídico - Lições de Filosofia do Direito, São Paulo, Ícone, 2006.

Teoria dell'ordinamento giuridico, trad. port. de Maria Celeste

Cordeiro Leite dos Santos, 10ª ed., Brasília, Universidade de Brasília, 1999. 
BOBBIO, Norberto; MATEUCCI, Nicola; PASQUINO, Gianfranco, Dizionario di Politica, trad. port. de Carmen C. Varriale et al., Dicionário de Política, $12^{\mathrm{a}}$ ed., v. 1 e v. 2, Brasília, Universidade de Brasília, 2004.

BODIN, Didier, Le pluralisme juridique en droit international privé, in Archives de philosophie du droit, n. 49, 2006, pp. 275-316.

BONELL, Michael Joachim, Do we need a Global Commercial Code, in Uniform Law Review, 2000, pp. 469-82.

, The UNIDROIT Principles and Transnational Law, in Uniform

Law Review, 2000, pp. 199-218.

, The UNIDROIT Principles of International Commercial

Contracts - The first 50 or so decisions, in New Trends in International Trade Law Contributions on the Occasion of the 10th Anniversary of the International Trade Law Course, Torino, G. Giappichelli, 2000, pp. 65-80.

, The UNIDROIT Principles of International Commercial

Contracts and CISG - Alternatives or Complementary Instruments, in Uniform Law Review, 1996, pp. 26-39.

, Un "codice" internazionale del diritto dei contratti - I Principi

UNIDROIT dei contratti commerciali internazionali, $2^{\mathrm{a}}$ ed. Milano, Giuffrè, 2006.

, Unidroit Principles 2004 - The New Edition of International

Commercial Contracts adopted by the International Institute for the Unification of Private Law, in Uniform Law Review, 2004, pp. 5-40.

BORTOLOTTI, Fabio, Manuale di diritto commerciale internazionale, v. 1, $2^{\mathrm{a}}$ ed., Padova, Cedam, 2003.

The ICC Model Contracts, in New Trends in International Trade

Law - Contributions on the Occasion of the $10^{\text {th }}$ Anniversary of the International Trade Law Course, Torino, G. Giappicheli, 2000, pp. 81-97.

The UNIDROIT Principles and the arbitral tribunals, in Uniform

Law Review, 2000, pp. 141-52.

BOSCHIERO, Nerina, La lex mercatoria nell'era della globalizzazione considerazioni di diritto internazionale pubblico e privato, in Sociologia del Diritto, v. 32, n. 2-3, 2005, pp. 83-155.

BROWNLIE, Ian, Principles of Public International Law, $5^{\mathrm{a}}$ ed, New York, Oxford, 1998. 
BLULFINCH, Thomas, The Age of Fable, trad. port. de David Jardim Júnior, O livro de ouro da mitologia - história de deuses e heróis, $5^{\text {a }}$ ed., Rio de Janeiro, Ediouro, 1999.

CALliGAN, Dennis J., Law in Modern Society, New York, Oxford University Press, 2007.

CASELLA, Paulo Borba, Utilização no Brasil dos Princípios UNIDROIT Relativos aos Contratos Comerciais Internacionais, in CASELLA, Paulo Borba (coord.), Arbitragem - Lei Brasileira e Praxe Internacional, 2a ed., São Paulo, LTr, 1999, pp. 99-105.

CASTELLS, Manuel, The rise of the network society, trad. port. de Roneide Venâncio Majer, A sociedade em rede - A era da informação - economia, sociedade e cultura, v. 1, São Paulo, Paz e Terra, 1999.

CASUCCI, Felice, Il diritto 'plurale' - Pluralismo delle fonti e libera circulazione delle norme giuridiche, Napoli, Edizioni Scientifiche Italiane, 2004.

COQUILlETTE, Daniel R., Incipit Lex Mercatoria, Que, Quando, Ubi, Inter Quos et de Qubius Sit - El Tratado de Lex Mercatoria en el Little Red Book de Brístol, in PETIT, Carlos (org.), Del Ius Mercatorum al Derecho Mercantil - 3 Seminario de Historia del Derecho Privado, Sitges 28-30 de Mayo de 1992, Madrid, Marcial Pons, 1997.

CORDEIRO, António Menezes, Da Boa-Fé no Direito Civil, Coimbra, Almedina, 2001.

CUTLER, A. Claire, Private Power and Global Authority - Transnational Merchant Law in the Global Political Economy, Cambridge, Cambridge, 2003.

DAL RI JÚNIOR, Arno, História do Direito Internacional - Comércio e Moeda Cidadania e Nacionalidade, Florianópolis, Fundação Boiteux, 2004.

DASSER, Felix, Lex Mercatoria - Critical Comments on a Tricky Topic, 2003, cf. disponível [on-line] in http://www.homburger.ch/fileadmin/publications/LMCRIT.pdf [4.1.2009].

DAVID, René, Il diritto del commercio internazionale - un nuovo compito per $i$ legislatori nazionali o una nuova lex mercatoria?, in Rivista di Diritto Civile, 1976, I, pp. $577-90$.

Les Grands Systèmes du Droit Contemporains, trad. port. de

Hermínio A. Carvalho, Os Grandes Sistemas do Direito Contemporâneo, $4^{\mathrm{a}}$ ed., São Paulo, Martins Fontes, 2002.

DELMAS-MARTY, Mireille, Les forces imaginantes du droit - le relatif e l'universel, Paris, Seuil, 2004. 
DEL VECCHIO, Giorgio, Storia della filosofia del diritto, trad. esp. de Luis Legaz y Lacambra, Historia de la filosofía del derecho, $2^{\mathrm{a}}$ ed., Barcelona, Bosch, 1964.

DE MASI, Domenico (org.), L'avvento post-industriale, trad. port. de Ana Maria Capovilla, Luiz Sérgio do Nascimento Henrique et al., A sociedade pós-industrial, $3^{\mathrm{a}}$ ed., São Paulo, Senac, 2000.

DEZALAY, Yves; GARTH, Bryant, Merchants of Law as Moral Entrepreneurs Constructing International Justice from the Competition for Transnational Business Disputes, in Law \& Society Review, v. 29, n. 1, 1995, pp. 27-64.

DEZALAY, Yves; TRUBEK, David M., A reestruturação global e o direito - a internacionalização dos campos jurídicos”, in FARIA, José Eduardo Campos de (org.), Direito e globalização econômica, São Paulo, Malheiros, 1998, pp. 29-80.

FARALLI, Carla, Certezza del diritto o diritto alla certezza?, in Materiali per una Storia della Cultura Giuridica, v. 27, n. 1,1997, pp. 89-104. La filosofia del diritto contemporanea, trad. port. de Candice Premaor Gullo, A filosofia contemporânea do direito - Temas e desafios, Martins Fontes, São Paulo, 2006.

, Vicende del pluralismo giuridico - tra teoria del diritto, antropologia e sociologia, in Sociologia del Diritto, v. 26, n. 3, 1999, pp. 89-102.

FERRARESE, Maria Rosaria, Diritto sconfinato - inventiva giuridica e spazi nel mondo globale, Roma-Bari, Laterza, 2006.

, Maria Rosaria, Il diritto al presente - globalizzazione e tempo delle istituzioni, Bologna, Il Mulino, 2002.

La lex mercatoria tra storia e attualità - da diritto dei mercanti a lex per tutti?, in Sociologia del Diritto, v. 32, n. 2-3, 2005, pp. 157-78.

Le istituzioni della globalizzazione - diritto e diritti nella società transnazionale, Bologna, Il Mulino, 2000.

FERRARI, Franco, General Principles and International Commercial Law Conventions - A Study of the 1980 Vienna Sales Convention and the 1988 Unidroit Conventions, in Uniform Law Review, 1997, pp. 465-73.

FERRARI, Vincenzo, Quesiti sociologici sulla lex mercatoria, in Sociologia del Diritto, v. 32, n. 2-3, 2005, pp. 7-27.

FORTIER, L. Yves, New trends in governing law - the new, new lex mercatoria, or, back to the future, in ICSID Review - Foreign Investment Law Journal, v. 16, n. 1, 2001, pp. 10-9. 
FORTUNATI, Maura, La lex mercatoria nella tradizione e nella recente ricostruzione storico-giuridica, in Sociologia del Diritto, v. 32, n. 2-3, 2005, pp. 29-41.

FRIGNANI, Aldo, L'arbitrato commerciale internazionale - v. XXXIII - Trattato di diritto commerciale e di diritto pubblico dell'economia diretto da Francesco Galgano, Padova, Cedam, 2004.

GAILLARD, Emmanuel, La distinction des principes généraux du droit et des usages du commerce international, in Etudes offertes à Pierre Bellet, Paris, Litec, 1991, pp. 203-17.

Transnational Law - A Legal System or a Method of Decision Making?, in Arbitration International, v. 17, n. 1, 2001, pp. 59-71.

, Trente ans de lex mercatoria - pour une application selective de la methode des principes generaux du droit, in Journal du Droit International, v. 122, n. 1, 1995, pp. 5-30.

GALGANO, Francesco, La globalizzazione nello specchio del diritto, Bologna, Il Mulino, 2005. , Lex Mercatoria, Bologna, Il Mulino, 2001.

GALGANO, Francesco; MARRELLA, Fabrizio, Diritto del commercio internazionale, Padova, Cedam, 2005.

GAMBARO, Antonio, Alcuni appunti sugli aspetti istituzionali della cosidetta globalizzazione, in Sociologia del Diritto, v. 32, n. 2-3, 2005, pp. 241-7.

GIARDINA, Andrea, La lex mercatoria e la certezza del diritto nei commerci e negli investimenti internazionali, in Rivista di Diritto Internazionale Privato e Processuale, v. 28, n. 3, 1972, pp. 461-70.

GILISSEN, John, Introduction historique au droit, trad. port. de António Manuel Botelho Hespanha e Manuel Luís Macaísta Malheiros, Introdução Histórica ao Direito, $4^{\mathrm{a}}$ ed., Lisboa, Calouste Gulbenkian, 2003. , Introduction a l'etude comparee du pluralisme juridique, in GILISSEN, John (org.), Le pluralisme juridique, Bruxelles, Université de Bruxelles, 1971.

GOLDMAN, Berthold, Frontières du droit et lex mercatoria, in Archives de philosophie du droit, n. 9, 1964, pp. 177-92. , Nouvelles Réflexions sur la Lex Mercatoria, in Festschrift Pierre Lalive, Basel, Frankfurt a.M., 1993, pp. 241-55. 
La lex mercatoria dans les contrats et l'arbitrage internationaux

- réalité et perspectives, in Journal du Droit International, 1979, pp. 475-99.

, The applicable law - general principles of law - the "lex

mercatoria", in Contemporary problems in international arbitration, Julian D.M. Lew,

Center for commercial Studies, London, 1986, pp. 113-25.

GOLDSCHMIDT, Levin, Universal-geschichte des Handelsrecht, trad. it. de Vittorio

Pouchain, Storia universale del diritto commerciale, Torino, Unione tipografico-editrice torinese, 1913.

GROSS, Charles, The Court of Piepowder, in The Quarterly Journal of Economics, v. 20, n. 2, 1906, pp. 231-249, cf. disponível [on-line] in http://www.jstor.org/stable/1883654 [20.4.2009].

GROSSI, Paolo, L’Europa del Diritto, Roma-Bari, Laterza, 2007.

Mitologie giuridiche della modernità, trad. port. de Arnaldo Dal

Ri Júnior, Mitologias jurídicas da modernidade, Florianópolis, Fundação Boiteaux, 2007.

HARTKAMP, Arthur S., Modernisation and Harmonisation of Contract Law Objectives, Methods and Scope, in Uniform Law Review, 2003, pp. 81-96.

HESPANHA, António Manuel, Cultura Jurídica Européia - Síntese de um Milênio, Florianópolis, Fundação Boiteux, 2005.

, O Caleidoscópio do Direito - O Direito e a Justiça nos Dias de

Hoje, Coimbra, Almedina, 2007.

HUCK, Hermes, Marcelo, Sentença Estrangeira e lex mercatoria - Horizontes e fronteiras do comércio internacional, Saraiva, São Paulo, 1994.

HYLAND, Richard, Pacta Sunt Servanda - Una reflexión, in PETIT, Carlos (org.), Del Ius Mercatorum al Derecho Mercantil, Marcial Pons, Madrid, 1997, pp. 359-81.

JARVIN, Sigvard e DERAINS, Yves, Collection of ICC Arbitral Awards 1974-1985, Kluwer Law and Taxation Publishers/Deventer, The Netherlands, 1990.

JESSUP, Philip C., Transnational Law, trad. port. de Carlos Ramires Pinheiro da Silva, Direito transnacional, Rio de Janeiro, Fundo de Cultura, 1956.

KAHN, Philippe, Droit international économique, droit du developpement, lex mercatoria - concept unique ou pluralisme des ordres juridiques?, in Droit des relations economiques internationales - etudes offertes a Berthold Goldman, Paris, Litec, 1982, pp. 97-107.

, La vente commercial internationale, Paris, Sirey, 1961. 
Les principes généraux du droit devant les arbitres du commerce international, in Journal du Droit International, v. 116, n. 2, 1989, pp. 304-27.

KASSIS, Antoine, L'autonomie de l'arbitrage commercial international - le droit français en question, L'Harmattan, Paris, 2005.

Théorie générale des usages du commerce - droit comparé,

contrats et arbitrage internationaux, lex mercatoria, Libr. générale de droit et de jurisprudence, Paris, 1984.

KELSEN, Hans, Reine Rechtslehre, trad. port. de João Baptista Machado, Teoria Pura do Direito, $6^{\circ}$ ed. São Paulo, Martins Fontes, 1999.

KERCHOVE, Michel van der; OST, François, Legal system between order and disorder, New York, Oxford, 1994.

KONRADI, Wioletta; FIX-FIERRO, HÉCTOR, Lex mercatoria in the mirror of empirical research, in Sociologia del Diritto, v. 32. n. 2-3, 2005, pp. 205-27.

LAGARDE, Paul, Approche critique de la lex mercatoria, in Droit des relations economiques internationales - etudes offertes a Berthold Goldman, Paris, Litec,1982, pp. $125-50$.

LALIVE, Pierre, Ordre Public Transnational (ou Réellement International) Et Arbitrage International, trad. port. de CASELLA, Paulo Borba, Ordem pública transnacional e arbitragem internacional - conteúdo e realidade da ordem pública transnacional na pratica arbitral, in Revista do Direito do Comércio e das Relações Internacionais, v. 1, n. 1, 1989, pp. 25-69.

LANDO, Ole, Assessing the Role of the UNIDROIT Principles in the Harmonization of Arbitration Law, in Tulane Journal of International and Comparative Law, 1994, pp. 129-43. Contract law in the EU - The Commission Action Plan and the

Principles of European Contract Law, disponível [on-line] in http://web.cbs.dk/departments/law/staff/ol/commission_on_ecl/literature/Lando/Respon se\%2016\%20May\%2003.doc [19-07-2004].

Some Features of the Law of Contract in the Third Millennium, disponível [on-line] in http://web.cbs.dk/departments/law/staff/ol/commission_on_ecl/literature/lando01.htm [19-07-2004]. The Lex Mercatoria In International Commercial Arbitration, in International and Comparative Law Quarterly, v. 4, n. 34, 1985, pp. 747-68. 
LEÃES, Luiz Gastão Paes de Barros, Notas sobre a Boa-Fé e a Lealdade Negocial, in Il Progetto UNIDROIT "Principi per i contratti commeciali internazionali" e l'unità e specifità del sistema giuridico latinoamericano, BONELL, Michael Joachim e CHIPANI, Sandro (org.), Padova, Cedam, 1996, pp. 71-3.

LOPES, José Reinaldo de Lima, As palavras e a lei - Direito, ordem e justiça na história do pensamento jurídico moderno, São Paulo, Ed. 34/Edesp, 2004.

O Direito na História - Lições Introdutórias, $2^{\mathrm{a}}$ ed., São Paulo,

Max Limonad, 2002.

LOQUIN, Eric, Oú en est la lex mercatoria?, in LEBEN, Charles; LOQUIN, Eric; SALEM, Mahmoud (org.), Souveraineté étatique et marchés internationaux à la fin du 20ème siècle, à propos de 30 ans de recherche du CREDIMI - mélanges en l'honneur de Philippe Kahn, Paris, Litec, 2000, pp. 23-51.

MACINTYRE, Alasdair, After Virtue, $2^{\mathrm{a}}$ ed., Notre Dame, University of Notre Dame Press, 2003.

MAGALHÃES, José Carlos de, "Lex Mercatoria" - Evolução e Posição Atual, in Revista dos Tribunais 709/1994, pp. 42-45.

O Supremo Tribunal Federal e o Direito Internacional - Uma análise Crítica, $1^{\mathrm{a}}$ ed, Porto Alegre, Livraria do Advogado, 2000.

MANN, Frederick A., England rejects 'delocalized' contracts and arbitration, in International and Comparative Law Quarterly, n. 33, v. 1, 1984, pp. 193-8.

MARCHI, Eduardo César Silveira Vita, Guia de Metodologia Jurídica - Teses, Monografias e Artigos, Lecce, Edizioni del Grifo, 2001.

MARRELLA, Fabrizio, La nuova lex mercatoria, Principi Unidroit ed usi dei contratti del commercio internazionale - v. XXX - Trattato di diritto commerciale e di diritto pubblico dell'economia diretto da Francesco Galgano, Padova, Cedam, 2003.

La nuova lex mercatoria tra controversie dogmatiche e mercato delle regole - Note di analisi economica del diritto dei contratti internazionali, in Sociologia del Diritto, v. 32, n. 2-3, 2005, pp. 249-85.

MAYER, Pierre, Le Principe de Bonne Foi devant les Arbitres du Commerce International, in Festschrift Pierre Lalive, Basel, Frankfurt a.M., 1993, pp. 543 e ss.

MERTENS, Hans-Joachim, Lex Mercatoria - A Self-applying System Beyond National law?, in TEUBNER, Gunther (org.), Global Law Without a State, Burlington, Ashgate, 2006, pp. 31-43. 
MONATERI, Pier Giuseppe, Lex mercatoria e competizione fra ordinamenti, in Sociologia del Diritto, v. 32. n. 2-3, 2005, pp. 229-40.

MUCHLINSKI, Peter T., Global Burkowina Examined - Viewing the Multinational Enterprise as a Transnational Law-Making Community, in TEUBNER, Gunther (org.), Global Law Without a State, Burlington, Ashgate, 2006, pp. 79-108.

MUSTILL, Michael, The New Lex Mercatoria - The First Twenty-five Years, in Arbitration International, 1988, pp. 86 e ss, cf. disponível [on-line] in www.translex.org/126900 [15.12.2009].

OLGIATI, Lex mercatoria e communitas mercatorum nell'esperienza giuridica contemporanea, in Sociologia del Diritto, v. 32, n. 2-3, 2005, pp. 351-78.

OPPETIT, Bruno, Philosophie d l'arbitrage commercial international, in Journal du Droit International, 1993, pp. 811-27.

OSMAN, Filali, Les principes généraux de la lex mercatoria - contribution à l'étude d'un ordre juridique anational, Paris, Libr. générale de droit et de jurisprudence, 1992.

OST, François, Jupiter, Hercules, Hèrmes - Trois Modelés du Juge, in BOURETZ, Pierre (org.), La Force du Droit - panorama des débats contemporains, Paris, Esprit, 1996, pp. 241-72.

PADOA-SCHIOPPA, Antonio, Brevi note storiche sulla lex mercatoria, in Sociologia del Diritto, v. 32, n. 2, 2005, pp.75-82.

PANNARALE, Luigi, Delocalizzazione del diritto e lex mercatoria - linee-guida per una politica dei diritti in una società transnazionale, in Sociologia del Diritto, v. 32, n. 2-3, 2005, pp. 309-28.

PICCIOTO, Sol, Regulatory Networks and Global Governance, cf. disponível [on-line] in http://eprints.lancs.ac.uk/232/1/reg_networks_\&_glob_gov.pdf [3.1.2010]

PELLET, Alain, La lex mercatoria "tiers ordre juridique"? - remarques ingenues d'un internationaliste de droit publique, in LEBEN, Charles; LOQUIN, Eric; SALEM, Mahmoud (org.), Souveraineté étatique et marchés internationaux à la fin du 20ème siècle, à propos de 30 ans de recherche du CREDIMI - mélanges en l'honneur de Philippe Kahn, Paris, Litec, 2000, pp. 54-74.

PINSOLLE, P., Distinction entre le principe de l'estoppel er le principe de bonne foi dans le droit du commerce international, in Journal du Droit International, 1998, pp. 905-931.

PUREZA, José Manuel, Defensive and oppositional counter-hegemonic uses of international law - from the international criminal court to the common heritage of 
humankind, in SANTOS, Boaventura de Sousa; RODRIGUEZ-GRAVITO, César A. (ed.), Law and Globalization from Below - Towards a Cosmopolitan Legality, Cambridge, 2005, pp. 267-80.

QUEIROZ, Everardo Nóbrega de, O Princípio da Boa-fé Objetiva ou da Razoabilidade como fundamento Jurídico da Lex Mercatoria, in AMARAL JÚNIOR, Alberto do (coord), Direito do Comércio Internacional, Juarez de Oliveira, São Paulo, 2002, pp. 79104.

RECHSTEINER, Beat Walter, Direito Internacional Privado - Teoria e Prática, $8^{\mathrm{a}}$ ed., São Paulo, Saraiva, 2005.

REIFEGERSTE, Stephan, WEISZBERG, Guillaume, Obligation de minimiser le dommage et 'raisonnable' en droit du commerce international in Revue du Droit des Affaires Internationaux, n. 2, 2004, pp. 181-97.

RENSMANN, Thilo, Anational arbitral awards - legal phenomenon of academic phantom?, in Journal of International Arbitration, v. 15, n. 2, 1998, pp. 37-65.

ROMANO, Santi, L'ordinamento giuridico, trad. franc. de Lucien François e Pierre Gothot, L'ordre juridique, $2^{\mathrm{a}}$ ed., Paris, Dalloz, 2002.

ROSETT, Arthur, The many paths to harmony in international commercial law, in New rends in International Trade Law - Contributions on the Occasion of the 10th Anniversary of the International Trade Law Course, Torino, G. Giappicheli, 2000, pp. 319-24.

Unification, Harmonization, Restatement, Codification and

Reform in International Commercial Law, in The American Journal of Comparative Law, 1992, pp. 688-97.

ROULAND, Norbert, Aux confins du droit, trad. port. de Maria Ermantina de Almeida Prado Galvão, Nos Confins do Direito, $1^{\mathrm{a}}$ ed., São Paulo, Martins Fontes, 2003.

SACCO, Rodolfo, Antropologia giuridica - contributo ad una macrostoria del diritto, Bologna, Il Mulino, 2007.

SACHS, Stephen E., From St. Ives to cyberspace - the modern distortion of the medieval law merchant, in American University International Law Review, v. 21, n. 5, 2006, pp. 685-812.

SANTOS, Boaventura de Sousa (org.), Conhecimento Prudente para uma Vida Decente - Um Discurso sobre as Ciências Revisitado, São Paulo, Cortez, 2004. 
SANTOS, Boaventura de Sousa, Notas sobre a História Jurídico-Social de Pasárgada, pp. 107-17, in SOUTO, Cláudio; FALCÃO, Joaquim (org.), Sociologia Jurídica leituras básicas de sociologia jurídica, São Paulo, Pioneira, 1980.

SANTOS, Boaventura de Sousa, law - A Map of Misreading - Toward a Post-Modern Concept of Law, in Journal of Law and Society, v. 14, n. 13, 1987,pp. 279-302.

SANTOS, Boaventura de Sousa; RODRIGUEZ-GRAVITO, César A., Law, politics, and the subaltern in counter-hegemonic globalization, in SANTOS, Boaventura de Sousa; RODRIGUEZ-GRAVITO, César A. (ed.), Law and Globalization from Below Towards a Cosmopolitan Legality, Cambridge, 2005, pp. 1-26.

SCHMITTHOFF, Clive, International Business law - A New Law Merchant, in Select Essays on International Trade, Chia-Jui Cheng (ed.), Dortrecht, Boston, London, Martinus Nijhoff Publishers e Graham\&Trotman, 1988, pp. 20-37. Nature and Evolution of the Transnational Law of Commercial Transactions, in Selected Essays on International Trade Law, Dortrecht, Boston, London, Martinus Nijhoff Publishers e Graham\&Trotman, 1988, pp. 231-42.

SHAH, Prakash, Legal Pluralism in Conflict - Coping with Cultural Diversity in Law, Cooggee, Cavendish Publishing, 2005.

SNYDER, Francis, Economic Globalisation and the Law in the $21^{\text {st }}$ Century, cf. disponível [on-line ] in http://www.francissnyder.com/tl_files/contents/articles/Economic_Globalisation_and_the_Law_in_the_21 st_Century_fin.pdf [3.1.2010].

STRENGER, Irineu, Contratos Internacionais do Comércio, $3^{\mathrm{a}}$ ed., São Paulo, LTr, 1998. , Da Autonomia da Vontade - direito interno e internacional, $2^{\mathrm{a}}$ ed., São Paulo, LTr, 2000.

Direito do Comércio Internacional e Lex Mercatoria, São Paulo, LTr, 1996.

SUPIOT, Alain, Homo Juridicus - Essai sur la function anthropologique du droit, trad. port. de Maria Ermantina de Almeida Prado Galvão, Homo Juridicus - ensaio sobre a função antropológica do direito, São Paulo, Martins Fontes, 2007.

TERRÉ, Dominique, Le pluralisme et le droit, in Archives de philosophie du droit, $\mathrm{n}$. 49, 2006, pp. 69-83. 
TEUBNER, Gunther, 'Global Burkowina' - Legal Pluralism in the World Society, in TEUBNER, Gunther (org.), Global Law Without a State, Burlington, Ashgate, 2006, pp. $3-28$. , Breaking Frames - La globalizzazione economica e l'emegere della lex mercatoria, in La cultura del diritto nell'epoca della globalizzazione L'emergere delle costituzioni civili, Roma, Armando, 2005.

Direito, Sistema e Policontexturalidade, Piracicaba, UNESP,

2005.

TREVES, Tullio, Lex Mercatoria Dei Naviganti, in Sociologia del Diritto, v. 32, n. 2-3, 2005, pp. 379-82.

TWINING, William, Globalization and legal theory, New York, Cambridge, 2006.

VANDERLINDEN, Jacques, Le pluralisme juridique - essai de synthèse, in GILISSEN, John (org.), Le pluralisme juridique, Bruxelles, Université de Bruxelles, 1971, pp. 19-56.

VIRALLY, Michel, Un tiers droit? - refléxions theoriques, in Droit des relations economiques internationales - etudes offertes a Berthold Goldman, Paris, Litec,1982, pp. 373-85.

VOLCKART, Oliver, Are the Roots of the Modern Lex Mercatoria Really Medieval?, in Southern Economic Journal, v. 65, n. 3, 1999, pp. 427-450, cf. disponível [on-line] in http://www.jstor.org/stable/1060808 [20.4.2009]

WALLERSTEIN, Immanuel, European Universalism - The Retoric Of Power, trad. port. de Beatriz Medina, O Universalismo Europeu - A Retórica do Poder, São Paulo, Boitempo, 2007.

WIEACKER, Franz, Privatsrechtgeschichte der Neuzeit unter Besonderer Berücksichtigung der Deutschen Entwicklung, trad. port. de António Manuel Botelho Hespanha, História do Direito Privado Moderno, $2^{\mathrm{a}}$ ed., Lisboa, Calouste Gulbenkian, 1967. 


\section{RESUMO}

A dissertação analisa o papel dos contratos comerciais internacionais na sociedade pósindustrial a partir da reflexão sobre os elementos, limites e desafios da nova lex mercatoria. A transição da sociedade industrial para a pós-industrial, moldada pela globalização e apoiada em maior ou menor parte em concepções pós-modernas, dá origem a características novas do direito. Assim, sob a perspectiva do pluralismo jurídico, - i.e., de um direito que não se funda necessariamente em um território ou espaço geográfico, mas que também pode existir e se desenvolver em um espaço jurídico - observa-se que a nova lex mercatoria, como expressão de um grupo social diferenciado (a business community ou societas mercatorum), constitui ordem jurídica transnacional de escopo limitado. Cabe então, identificar seus principais elementos âmbito de aplicação (contratos comerciais internacionais), atores (públicos privados ou de caráter coletivo, nacionais, internacionais ou transnacionais), fontes normativas (princípios gerais - especialmente os Princípios UNIDROIT, usos e jurisprudência arbitral) - e respectivas fontes de cognição, bem como os limites impostos pela ordem pública dos Estados, transnacional e internacional. Com o reconhecimento da produção de regras jurídicas por autoridades privadas, a reflexão deve se voltar às críticas que questionam sua legitimidade e identificam a nova lex mercatoria como meio de privilegiar interesses econômicos dos que detém maior poder (principalmente as empresas transnacionais dos Estados do Norte, do Ocidente) em detrimento de outros interesses econômicos, sociais ou políticos. A correção desse curso (trajetória) da nova lex mercatoria baseia-se na concepção de que o contrato deve transcender a esfera puramente individual e na imposição de novos parâmetros pelo direito internacional ao qual a nova lex mercatoria se subordina - que devem ser implementados principalmente pela arbitragem comercial internacional. 


\section{ZUSAMMENFASSUNG}

Diese Arbeit beschäftigt sich mit der Rolle der internationalen kommerziellen Verträge in der Post-industrielle Gesellschaft nach Reflexionen über die Elemente, die Grenzen, und die Herausforderungen der neuen Lex Mercatoria. Der Übergang von der industriellen Gesellschaft zu der post-industriellen Gesellschaft, von der Globalisation geprägt und mehr oder weniger von post-modernen Konzeptionen inspiriert, verursacht neue Eigenschaften an das Recht. Demnach folgert heraus, unter der Perspektive des juristischen Pluralismus, dass die neue Lex Mercatoria, als Ausdruck einer besonderen sozialen Gruppe (business comunity, oder societas mercatorum), eine transnationale zwecksbegrenzte juristische Ordnung ausmacht. Der juristische Pluralismus entspricht einem nicht unbedingt von einem bestimmten geographischen Raum hergestellten, aber immer hin in einem juridischen Raum bestehenden und sich entwickelnden Recht. Es ist zuerst nötig, die Hauptelemente von Lex Mercatoria- Verwendungsbereich (internationalen kommerziellen Verträge), Schauspieler (öffentlich, privat, national, international oder transnational), normative Quellen (generelle Prinzipien hauptsächlich die Prinzipien von UNIDROIT, Gebräuche und schiedsgerichterliche Rechtsprechung, jeweilige Erkenntnissquellen, wie auch die aus staatlichen, transnationalen und internationalen öffentlichen Ordnung Grenzen festzustellen. Die Annerkennung der von Privatautoritäten hergestellten juristichen Regeln führt die Reflexionen an die Beschäftigung mit den Kritiken, die die Legitimität der neuen Lex Mercatoria bestreiten und die neue Lex Mercatoria als Mittel zur Privilegien der Wirtschaftinteressen einer Gruppe, die mehr Wirtschaftmacht hat (hauptsächlich transnationalen abendländischen Firmen oder Nordfirmen) zum Schaden anderer Wirtschaft-, Sozial- oder Politikinteressen feststellen. Die Vorschlag einer Bearbeitung der neuen Lex Mercatoria basiert sich auf die Idee, dass der Vertrag das bloße individualle Bereich überschreiten soll, und auf die Entstehung von neuen Parametern (die hauptsächlich von der kommerziellen schiedsgerichterlichen Rechtsprechung eingeführt sollen) vom Volksrecht, dem die neue Lex Mercatoria undtergeordnet ist. 